UNIVERSIDADE DE SÃO PAULO

FACULDADE DE EDUCAÇÃO

ANDREA BEATRIZ GONZALEZ FRIGO

Práticas de escrita em contextos de alfabetização: caminhos e descaminhos 
ANDREA BEATRIZ GONZALEZ FRIGO

Práticas de escrita em contextos de alfabetização: caminhos e descaminhos

\section{Versão Corrigida}

Dissertação apresentada à Faculdade de Educação da Universidade de São Paulo para obtenção do título de Mestre em Educação.

Área de Concentração: Linguagem e Psicologia.

Orientadora: Prof. $\stackrel{a}{ } \quad$ Dr. ${ }^{\underline{a}}$ Silvia $M$. Gasparian Colello. 
Autorizo a reprodução e divulgação total ou parcial deste trabalho, por qualquer meio convencional ou eletrônico, para fins de estudo e pesquisa, desde que citada a fonte.

Catalogação da Publicação

Ficha elaborada pelo Sistema de Geração Automática a partir de dados fornecidos pela autora Bibliotecária da FE/USP: Nicolly Soares Leite - CRB - 8/8204

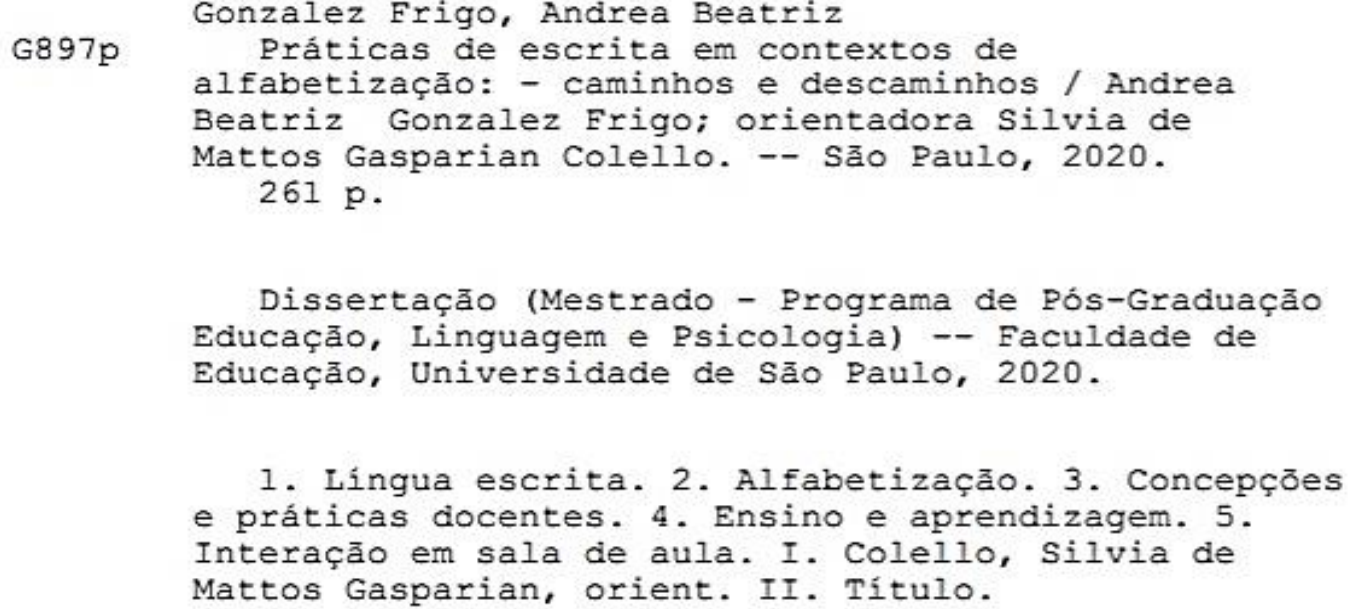


Nome: GONZALEZ FRIGO, Andrea Beatriz

Título: Práticas de escrita em contextos de alfabetização: caminhos e descaminhos

Dissertação apresentada à Faculdade de Educação da Universidade de São Paulo para obtenção do título de Mestre em Educação.

Aprovado em:

Banca Examinadora

Prof. Dr.

Instituição:

Julgamento:

Prof. Dr.

Instituição:

Julgamento:

Prof. Dr.

Instituição:

Julgamento: 
A meu pai, onde estiver. 


\section{AGRADECIMENTOS}

\section{Gratidão! Gratidão! Gratidão!}

À vida, que me deu a oportunidade de viver a experiência do mestrado, um momento ímpar de autoconhecimento e transformação pessoal, de mudança de paradigmas e de descobrir novas lentes para ver o mundo e a mim mesma. Uma experiência vital, de construção de sentidos e de conquista da própria voz na relação com outros.

À Cristine Conforti, que com seu exemplo e estímulo, acreditou em minhas potências e avivou em mim a possibilidade de cursar o mestrado.

À professora Dr. ․ Silvia Colello, que me ajudou a concretizar essa possibilidade. Orientadora e parceria incondicional na caminhada, com paciência, disponibilidade e generosidade, acolheu minhas dúvidas e guiou meus passos até aqui. Sua postura ética e o rigoroso zelo pelo conhecimento científico foram cruciais para fazer de mim uma pesquisadora. Com afeto e admiração, agradeço a oportunidade de poder contar com seu cuidado e orientação!

Aos professores Nilson José Machado e Rinaldo Voltolini, pela generosidade com que me acolheram em suas aulas, pelas leituras relevantes e pela oportunidade de reflexão e diálogo.

A meu querido Romi, marido e companheiro amoroso, que tantas vezes esteve a meu lado, muitas sem nada dizer, mas com uma presença constante e cuidadosa. Foram diversas as situações em que o carinho e o companheirismo se fizeram presentes e me deram força para seguir adiante, pois eu sabia: ele estava lá!

À Aline, filha amorosa e parceira atenta, que esteve sempre a meu lado, interessada pelos rumos da pesquisa. Leitora crítica exigente, muitas vezes pontuou, acertadamente, meu texto, contribuindo para a observação de detalhes importantes que me haviam escapado. Devo à sua assertividade e clareza a correção de rotas ao longo do caminho. Seu carinho, generosidade e presença foram fundamentais nos momentos difíceis!

À minhas amadas irmãs, Diana e Laura, que me acompanharam e incentivaram, mesmo à distância.

À Ligia Barbagallo, amiga-irmã eleita por toda a vida, por estar sempre comigo, em atitudes, pensamento e coração. Sua força e companheirismo foram fundamentais 
quando a tarefa exigiu maior empenho. Pelo amor e com alegria, nossos corações celebram juntos mais este momento.

À Denise Martins, amiga a quem muito amo e admiro, agradeço pelas discussões nas mesas de bar, quando discutíamos a profissão docente entre tantas outras conversas sobre a vida. Sua escuta, afetiva e atenta, além da disponibilidade para "pensar junto", extrapolam a prática de sala de aula que um dia compartilhamos e revigora em mim o desejo de ser uma pessoa melhor.

Às queridas Bia, Vanessa, Lúcia e Regina, parceiras da educação, pela paciência, pela companhia no percurso e por tudo o que aprendo na convivência diária com elas. Estarmos juntas vivifica em mim a crença de que as diferenças sempre podem somar... e fazer diferença!

À Vivian Augusto, pela revisão cuidadosa, pela disponibilidade e parceria. Seu olhar profissional e apoio fizeram toda a diferença para a conclusão deste trabalho.

Aos educadores da EMEF Espiridião Rosas, que me receberam de braços abertos e se dispuseram a compartilhar o que sabem em nome da pesquisa científica. Suas contribuições foram valiosas e revelaram o compromisso e a responsabilidade com que se dedicam à educação pública. Agradeço, igualmente, aos alunos do primeiro e segundo anos, por terem partilhado comigo suas leituras de mundo, em que valorizam o universo da escrita como fonte de desejo e curiosidade. 
E foi assim... num misto de familiaridade $e$ respeito, ela abriu e leu.

Algumas acenavam pontes, outras, divisas.

Algumas abriam portas, outras fechavam ciclos. Algumas eram presentes; outras, oferendas.

Por vezes reveladoras, curiosas, ríspidas ou acolhedoras. Talvez murmurantes, urgentes, de ordem, ultrapassadas.

"Online", de boca, na ponta da pena... De que importa?

Foi então que ela se deu conta: tudo por uma antiga paixão, seu amor incondicional pela palavra! 


\section{RESUMO}

GONZALEZ FRIGO, Andrea Beatriz. Práticas de escrita em contextos de alfabetização: caminhos e descaminhos. 2020. 261 f. Dissertação (Mestrado em Educação) - Faculdade de Educação, Universidade de São Paulo, São Paulo, 2020.

Considerando a contradição entre o avanço das contribuições científicas e o cenário educacional brasileiro de baixo aproveitamento escolar, a presente pesquisa, tomando a língua escrita como objeto de investigação, teve por objetivo conhecer as concepções e as práticas docentes que incidem no processo de alfabetização, isto é, os condicionantes que afetam as propostas de escrita na escola. Para tanto, os referenciais interacionistas de aprendizagem e dialógicas de língua (Piaget, Vigotski, Bakhtin e Ferreiro), ancoraram o estudo de caso realizado em duas classes de Ensino Fundamental 1 (1을 e $2^{\circ}$ anos) da Escola Municipal de Ensino Fundamental Espiridião Rosas (SP). Visando mapear o trabalho desenvolvido em cada turma e, ainda, a perspectiva de progressão no Ciclo de Alfabetização, o estudo pautou-se em três eixos de investigação, que foram analisados nos âmbitos teórico e prático (mais especificamente, o dizer e o fazer das professoras): a língua, o processo de ensino e aprendizagem, e a interação em sala de aula. As duas entrevistas realizadas com as respectivas professoras de classe, as 54 observações das atividades de ensino da escrita e os dados complementares registrados em um Diário de Campo constituem o corpus de investigação deste estudo. O resultado da pesquisa mostra que concepções, nem sempre conscientes, subsidiam a ação docente, e que, mesmo quando estas são claramente assumidas, não garantem a concretização das diretrizes de ensino assumidas ou a otimização dos processos de aprendizagem Decorre dessa conclusão a necessidade de repensar a formação inicial e em serviço dos professores, investigando como esses processos têm se colocado na constituição dos docentes, bem como na articulação que podem fazer entre teoria e prática.

Palavras-chave: Língua escrita. Alfabetização. Concepções docentes. Prática pedagógica. Ensino-aprendizagem. Interações em sala de aula. 


\begin{abstract}
GONZALEZ FRIGO, Andrea Beatriz. Writing practices in literacy contexts: paths and detours. 2020. 261 p. Dissertation (Master degree in Education) - Faculty of Education, University of São Paulo, São Paulo, 2018.

Considering the contradiction between the advancement of scientific contributions and the Brazilian educational scenario of low school performance, the present research, taking the written language as an object of investigation, aimed to understand the conceptions and teaching practices that affect the literacy process, that is, the conditioning factors that affect writing proposals at school. For that, the interactionist referential of learning and dialogical language (Piaget, Vigotski, Bakhtin and Ferreiro), anchored the case study carried out in two classes of Elementary School 1 (1st and 2nd years) of the Municipal School of Elementary Education Espiridião Rosas (SP). Aiming to map the work developed in each class and, also, the perspective of progression in the Literacy Cycle, the study was guided by three research axes, which were analyzed in the theoretical and practical spheres (more specifically, the saying and doing of the teachers): language, the teaching and learning process, and classroom interaction. The two interviews carried out with the respective class teachers, the 54 observations of the teaching activities of writing and the complementary data recorded in a Field Diary constitute the corpus of investigation of this study. The result of the research shows that conceptions, not always conscious, support the teaching actions, and that, even when these are clearly assumed, they do not guarantee the implementation of the supposed teaching guidelines or the optimization of the learning processes. It follows from this conclusion the need to rethink the initial and in-service training of teachers, investigating how these processes have been placed in the constitution of teachers, as well as in the articulation they can make between theory and practice.
\end{abstract}

Keywords: Written language. Literacy. Teaching conceptions. Pedagogical practice. Teaching-learning. Classroom interactions. 


\section{LISTA DE FIGURAS}

Figura 1 - Mapa do bairro Jaguaré, zona oeste da cidade de São Paulo................137

Figura 2 - Entrada principal da EMEF Mal. Espiridião Rosas.................................139

Figura 3 - Quadra de esportes coberta .......................................................142

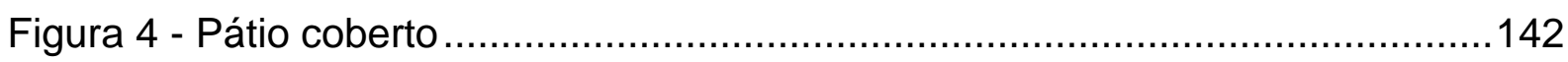

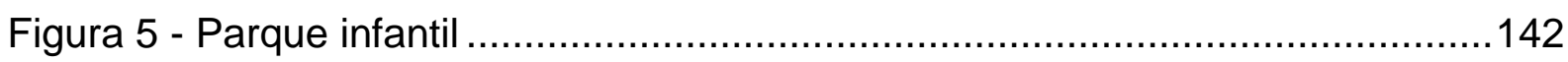

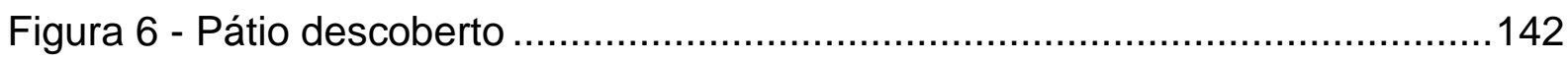

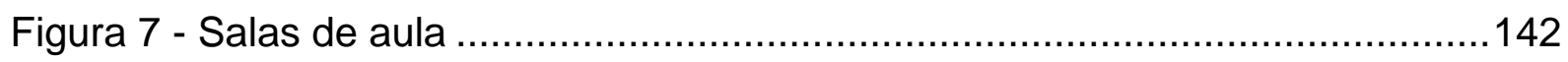

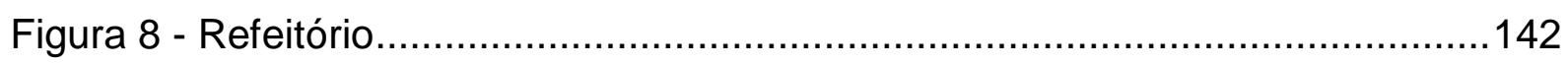

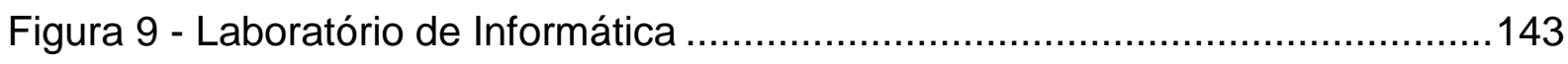

Figura 10 - Sala de leitura ..........................................................................143

Figura 11 - Livro didático dos alunos das séries iniciais do Ensino Fundamental ...153

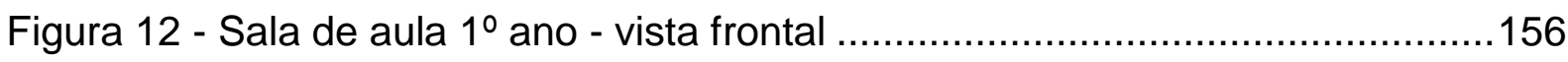

Figura 13 - Sala de aula $1^{\circ}$ ano - vista lateral a.................................................156

Figura 14 - Sala de aula $1^{\circ}$ ano - vista lateral b...............................................157

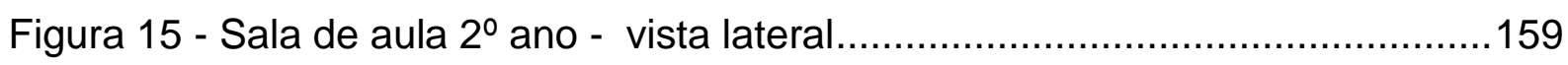

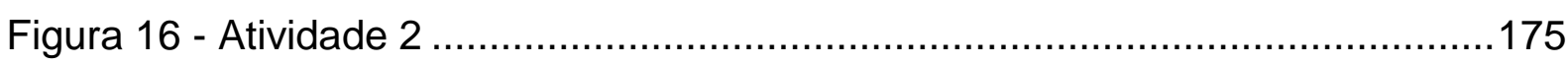

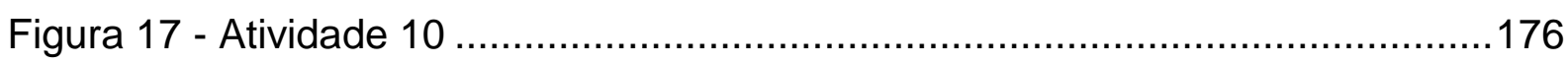

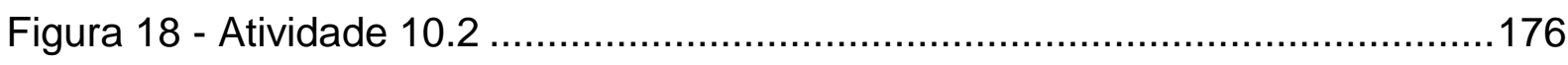

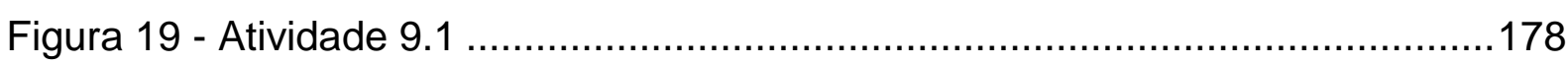

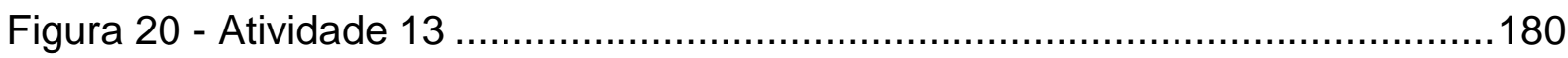

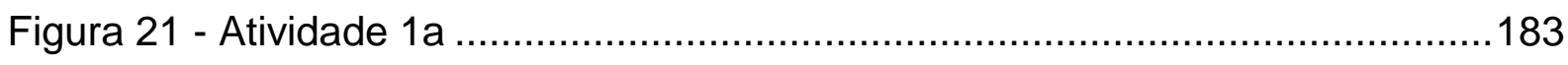

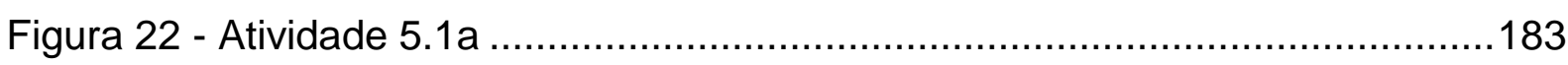

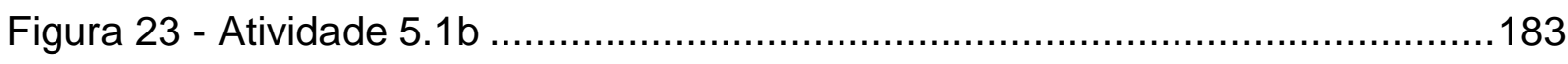

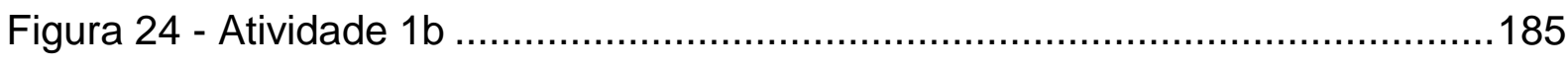

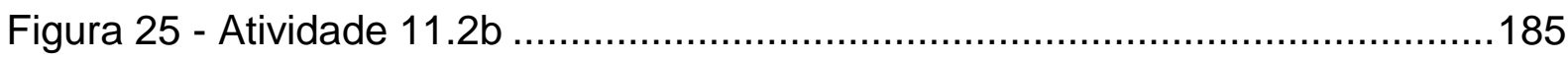

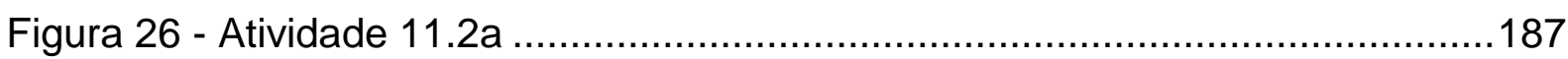

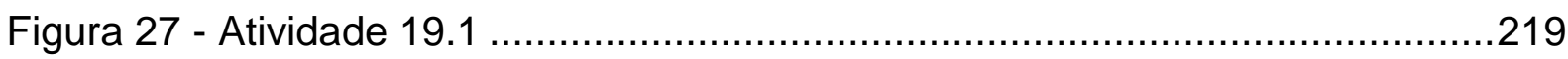

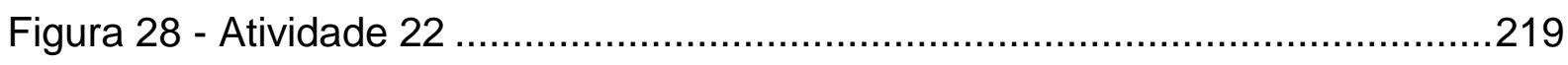

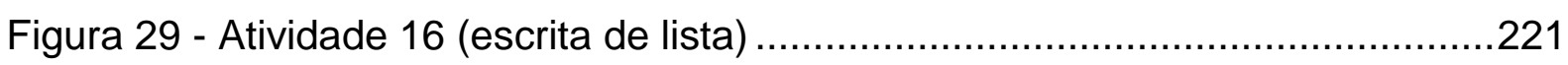

Figura 30 - Escrita de cabeçalho e rotina .........................................................222 


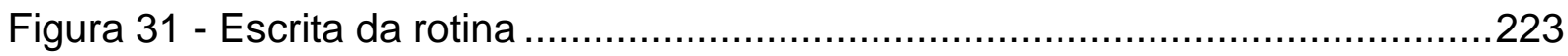

Figura 32 - Atividade 18 (escrita de bilhete) ……............................................224

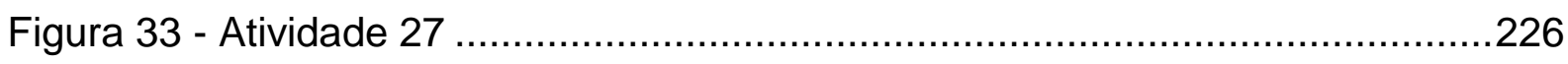

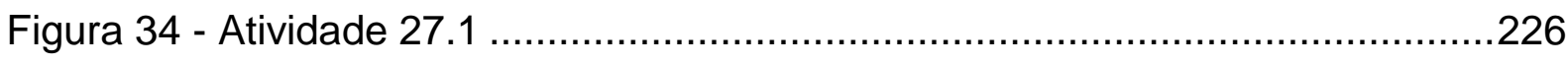

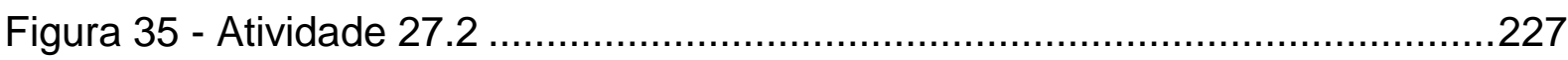




\section{LISTA DE QUADROS}

Quadro 1 - Níveis de Alfabetismo segundo escala INAF - comparativo anterior e

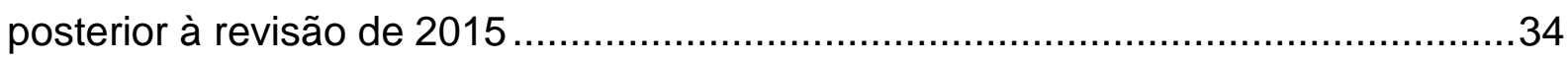

Quadro 2 - Escala de proficiência por níveis de alfabetismo.....................................35

Quadro 3 - Descrição da escala de proficiência de escrita .......................................39

Quadro 4 - Descrição da escala de proficiência de leitura ..................................... 41

Quadro 5 - Concepções de homem, mundo e conhecimento …….........................75

Quadro 6 - Tendências ancoradas na compreensão periférica das diretrizes ou pela má interpretação dos princípios psicogenéticos ....................................................96

Quadro 7 - Concepções de língua e suas implicações para o ensino ......................101

Quadro 8 - Observação e acompanhamento da classe do $1^{\circ}$ ano do Ensino Fundamental da Rede Pública de ensino............................................. 131

Quadro 9 - Roteiro de entrevistas aos docentes ................................................132

Quadro 10 - Síntese da entrevista realizada com os professores .........................133

Quadro 11 - Eixos e âmbitos de análise.........................................................135

Quadro 12 - Síntese de dados coletados durante observação em sala ..................136

Quadro 13 - Concepções assumidas pela professora Bianca - 1ํano (Entrevista) 167

Quadro 14 - Propostas de escrita junto aos alunos do $1^{\circ}$ ano ...............................168

Quadro 15 - Perspectivas de Ensino e de Aprendizagem - $1^{\circ}$ ano........................190

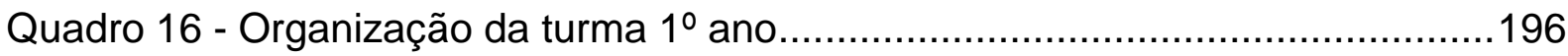

Quadro 17 - Processos interativos presentes nas atividades de escrita - $1^{\circ}$ ano $\ldots . .198$

Quadro 18 - Práticas dialogadas entre professora e alunos - 1ㅇa ano ......................199

Quadro 19 - Concepções assumidas pela professora Raquel - $2^{\circ}$ ano (Entrevista)204

Quadro 20 - Propostas de escrita junto aos alunos do $2^{\circ}$ ano ……........................205

Quadro 21 - Perspectivas de Ensino e de Aprendizagem - $2^{\circ}$ ano..........................216

Quadro 22 - Aspectos notacionais priorizados nas atividades de escrita................220

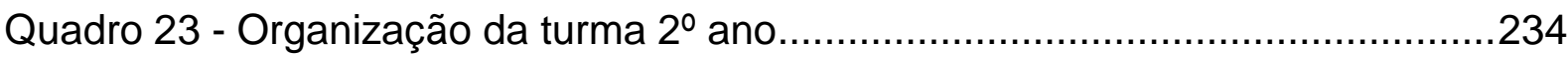

Quadro 24 - Processos interativos presentes nas atividades de escrita - $2^{\circ}$ ano....235

Quadro 25 - Comparação entre concepções e práticas docentes - 1ํ e $2^{\circ}$ anos ....238

Quadro 26 - Análise comparativa - $1^{\circ}$ e $2^{\circ} \stackrel{0}{ }$ anos. 240 


\section{LISTA DE TABELAS}

Tabela 1 - Níveis de alfabetismo no Brasil conforme o INAF (2001-2018)..............36

Tabela 2 - Índices de aprovação IDEB/SAEB - EMEF Espiridião Rosas ................146

Tabela 3 - Meta e valor de referência EMEF Espiridião Rosas .............................147

Tabela 4 - Aproveitamento Escolar em Língua Portuguesa- 4ํㅡㄹ bimestre 2018 .......149 


\section{LISTA DE GRÁFICOS}

Gráfico 1 - Percentual de pessoas de 6 a 14 anos que frequentavam ou já tinham concluído o Ensino Fundamental - Brasil - 2004-2017 .........................31

Gráfico 2 - Resultados - Proficiência Escrita Brasil 2016 ......................................42

Gráfico 3 - Resultados - Proficiência Leitura Brasil 2016 ......................................43

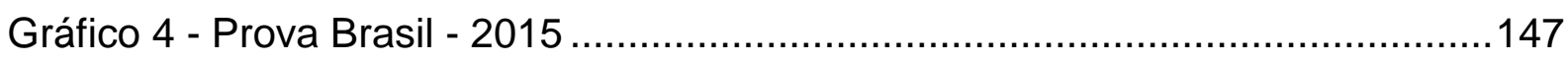

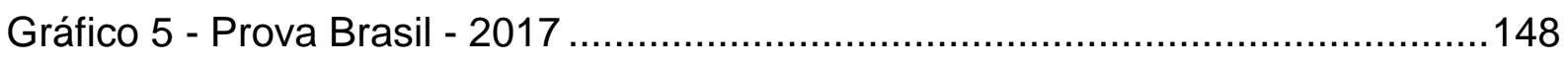

Gráfico 6 - Distribuição das práticas de linguagem ............................................173 


\section{LISTA DE SIGLAS}

$\begin{array}{ll}\text { AEE } & \text { Atendimento Educacional Especializado } \\ \text { ANA } & \text { Avaliação Nacional de Alfabetização } \\ \text { APM } & \text { Associação de Pais e Mestres } \\ \text { ATE } & \text { Auxiliar Técnico } \\ \text { BNCC } & \text { Base Nacional Comum Curricular } \\ \text { CIEE } & \text { Centro de Integração Empresa Escola } \\ \text { CNE } & \text { Conselho Nacional de Educação } \\ \text { DRE } & \text { Diretoria Regional de Educação } \\ \text { EJA } & \text { Educação de Jovens e Adultos } \\ \text { EMEF } & \text { Escola Municipal de Ensino Fundamental } \\ \text { EMEI } & \text { Escolas Municipais de Educação Infantil } \\ \text { FMI } & \text { Fundo Monetário Internacional } \\ \text { IBGE } & \text { Instituto Brasileiro de Geografia e Estatística } \\ \text { IBOPE } & \text { Instituto Brasileiro de Opinião Pública e Estatística } \\ \text { IDEB } & \text { Índice de Desenvolvimento da Educação Básica } \\ \text { IPM } & \text { Instituto Paulo Montenegro } \\ \text { INAF } & \text { Indicador Nacional de Alfabetismo Funcional } \\ \text { INEP } & \text { Instituto Nacional de Estudos e Pesquisas Educacionais Anísio } \\ & \text { Teixeira } \\ \text { JBD } & \text { Jornada Básica Docente } \\ \text { JEIF } & \text { Jornada Especial Integral de Formação } \\ \text { LDB } & \text { Lei de Diretrizes e Bases da Educação Nacional } \\ \text { MEC } & \text { Ministério da Educação } \\ \text { OCDE } & \text { Organização para a Cooperação e Desenvolvimento Econômico } \\ \text { ODS } & \text { Objetivo de Desenvolvimento Sustentável } \\ \text { OMC } & \text { Organização Mundial do Comércio } \\ \text { ONG } & \text { Organização Não Governamental } \\ \text { PCN } & \text { Parâmetros Curriculares Nacionais } \\ \text { PDE } & \text { Plano de Desenvolvimento da Educação } \\ \text { PEA } & \text { Projeto Especial de Ação } \\ \text { PISA } & \text { Programa Internacional de Avaliação de Estudantes } \\ \text { PNAD } & \text { Pesquisa Nacional por Amostra de Domicílio } \\ \end{array}$


PNAIC Pacto Nacional pela Alfabetização na Idade Certa

PNE Plano Nacional de Educação

PPP Projeto Político Pedagógico

SAEB Sistema de Avaliação da Educação Básica

SARESP Sistema de Avaliação de Rendimento Escolar do Estado de São Paulo

SGP Sistema de Gestão Pedagógica

SME-SP Secretaria Municipal de Educação de São Paulo

SNE Sistema Nacional de Educação

UNESCO Organização das Nações Unidas para Educação, Ciência e Cultura

UNIVESP Universidade Virtual do Estado de São Paulo

ZDP Zona de Desenvolvimento Proximal 


\section{SUMÁRIO}

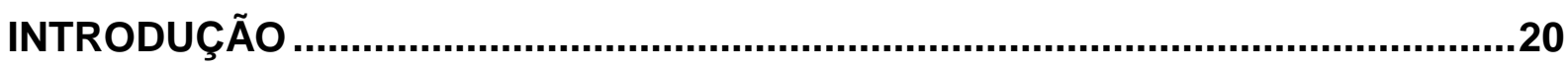

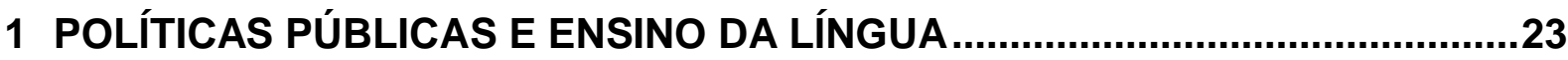

1.1 Sobre os direitos à educação e ao processo de alfabetização ......................23

1.2 As políticas públicas de educação: entre a intenção e a realidade ...............28

2 CONCEPÇÕES DE APRENDIZAGEM ..........................................................

2.1 Concepções fixista de mundo e essencialista de homem ……...................50

2.1.1 Implicações do fixismo e do essencialismo .........................................51

2.2 Concepções transformista de mundo e relacionista de homem ....................57

2.2.1 Implicações pedagógicas do transformismo e do relacionismo ............58

2.3 Piaget e Vigotski: convergências e divergências ........................................74

3 A LÍNGUA ESCRITA COMO OBJETO DE INVESTIGAÇÃO E ENSINO .............76

3.1 Concepções de língua e formação docente …………………………......76

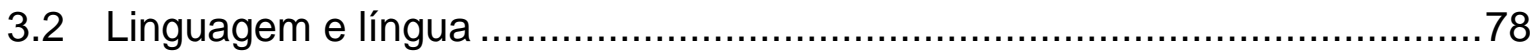

3.3 A contribuição da linguística e da abordagem histórico-cultural ....................82

3.4 A contribuição da Psicogênese ..........................................................

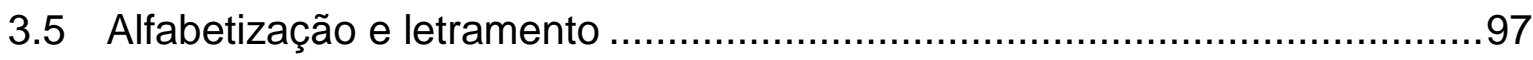

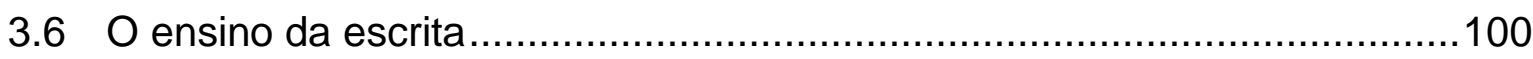

4 A INTERAÇÃO NOS PROCESSOS DE APRENDIZAGEM .............................106

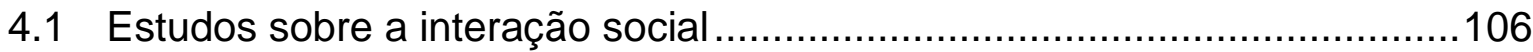

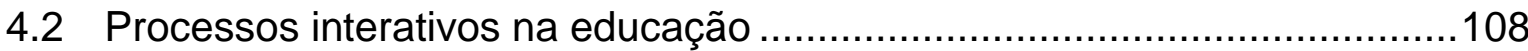

4.3 Ensino, aprendizagem e processos interativos nos contextos de sala de aula

4.4 Agrupamentos e dinâmicas relacionais ...............................................118

4.5 Alfabetização e Letramento em contextos interativos................................122

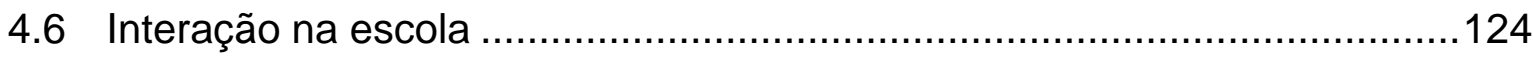

5 DELINEANDO O PROCESSO DE PESQUISA …...........................................126

5.1 Problema, justificativa, hipótese e objetivos ...........................................126

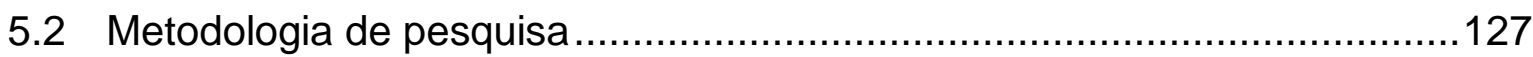

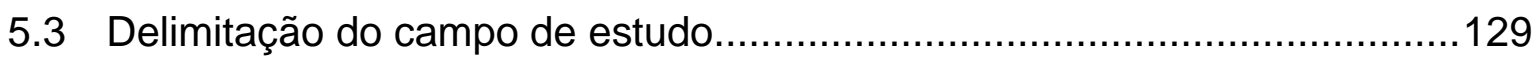

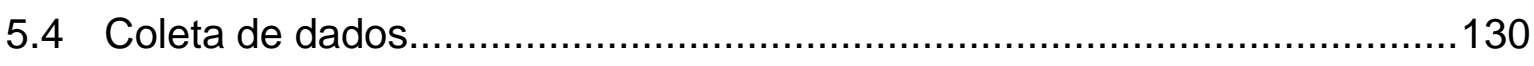

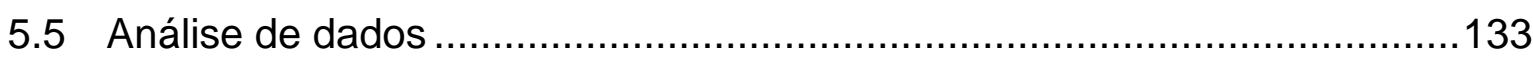


6 CONTEXTO DA PESQUISA.

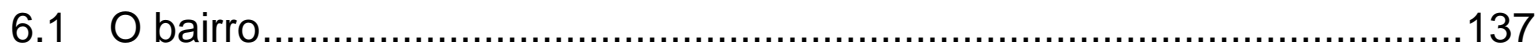

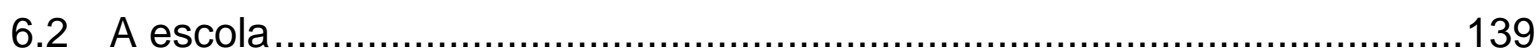

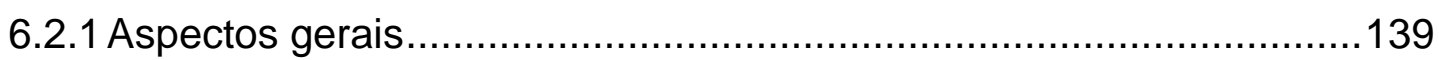

6.2.2 A organização do espaço e do tempo escolares...............................141

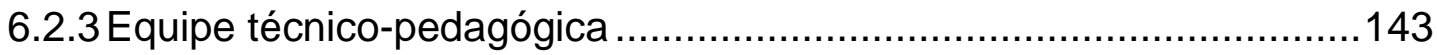

6.2.4 A escola no cenário dos sistemas de avaliação ................................145

6.3 O Currículo da Cidade e o Projeto Político Pedagógico da escola ..............150

6.4 Recursos didáticos do ensino de Língua Portuguesa................................152

7 PROFESSORES E ALUNOS NO CONTEXTO DA PESQUISA.........................154

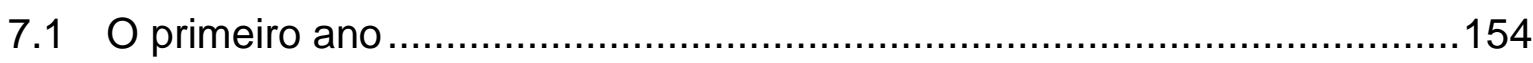

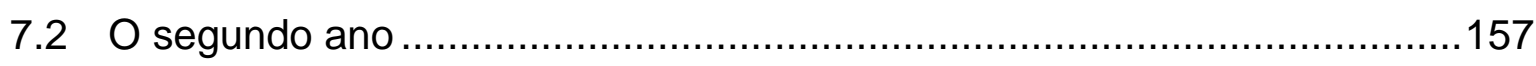

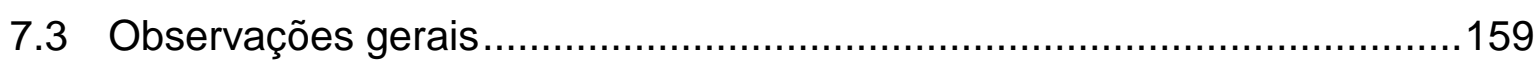

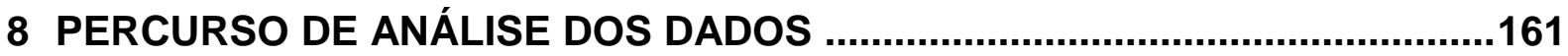

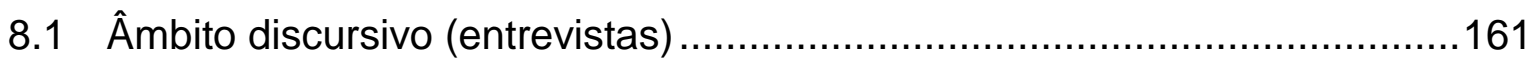

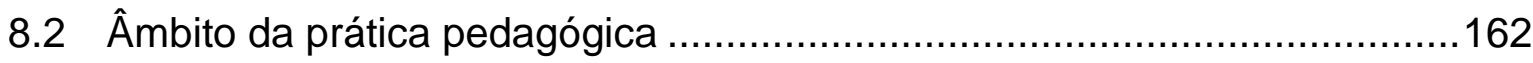

9 CONCEPÇÕES E PRÁTICAS DE ESCRITA NO PRIMEIRO ANO …...............166

9.1 Concepções Docentes e Práticas Pedagógicas ……………………….....166

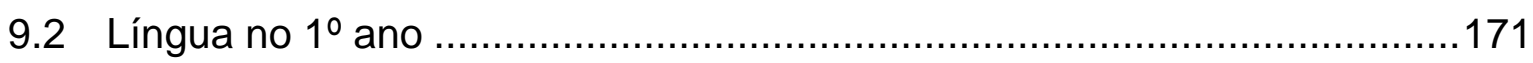

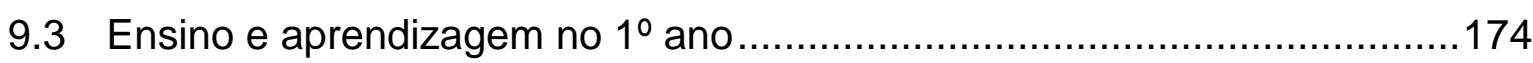

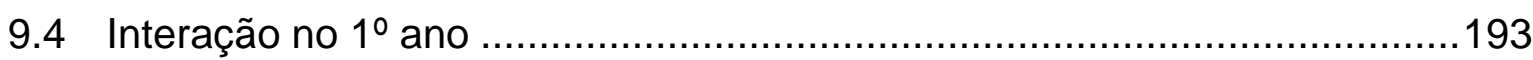

10CONCEPÇÕES E PRÁTICAS DE ESCRITA NO SEGUNDO ANO ….................203

10.1 Concepções Docentes e Práticas Pedagógicas .........................................203

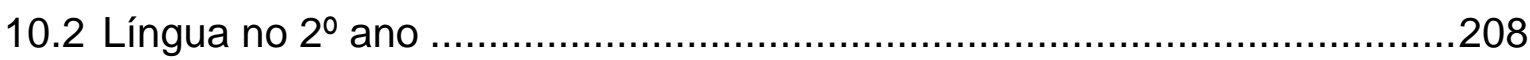

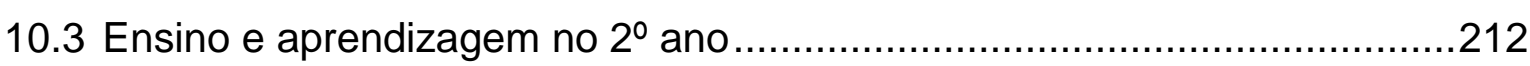

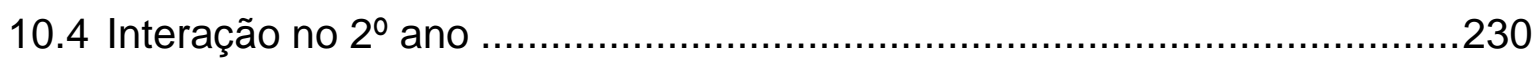

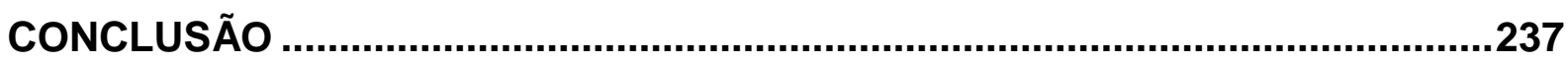

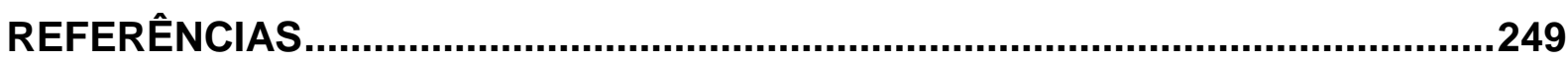

APÊNDICE 


\section{INTRODUÇÃO}

Conceber um projeto de investigação sobre práticas pedagógicas pressupõe a necessidade de se considerar as concepções e diretrizes de ensino, o papel da educação escolar, e da intervenção pedagógica. Isso porque, diferentemente de situações informais, em que a criança aprende por imersão social, é na escola que a aprendizagem é privilegiada, pois é aí o lugar em que há, precisamente, a intencionalidade de promovê-la. Nesse sentido, o professor deve ter como objetivo explícito intervir sistemática e propositalmente no processo de aprendizagem do aluno, de modo a provocar e oportunizar o acesso a campos de conhecimento e a progressos que não ocorreriam espontaneamente.

No entanto, ainda que a escola revele o propósito de fazer bem aquilo a que se dispõe, e a despeito do avanço alcançado pelas ciências da educação, linguísticas e pela psicologia, o ensino da língua escrita nesse ambiente tem se mostrado ineficiente, apesar das inúmeras boas intenções.

Recorrentes dados censitários demonstram que, se por um lado, foi alcançada a meta de se democratizar o acesso à escolaridade formal, o mesmo não se deu em relação à melhoria na qualidade da educação ofertada (particularmente, no que diz respeito à aprendizagem da língua portuguesa), a qual não vem correspondendo aos esforços empreendidos.

Índices oficiais reconhecidos pelo Ministério da Educação (MEC) mostram que os níveis de evasão e de repetência ainda causam significativas distorções na relação entre idade/série, interferindo, com efeito, na vida escolar dos alunos, especialmente quando estes chegam à adolescência; também é relevante o número de alunos que frequentam regularmente a escola, mas, ainda assim, não atingem níveis satisfatórios de alfabetismo.

Portanto, analisar esse cenário exige o cuidado de não se sujeitar a respostas reducionistas ou pouco consistentes. Isso porque as políticas educacionais e as práticas de formação evidenciam que o domínio da língua não é um problema que se restringe à escola, mas também lhe pertence; daí o interesse em pesquisar e analisar o contexto de ensino (concepções e práticas pedagógicas) buscando compreender as dificuldades que a instituição escolar tem enfrentado.

Cientes de que todo processo de investigação que se pretende científico está apoiado em bases epistemológicas, métodos e técnicas específicas, assumimos um 
referencial fundamentado no paradigma interacionista, isto é, na reciprocidade sujeitoobjeto mediado pela interação social ao longo do tempo histórico.

Tal opção paradigmática se sustenta na compreensão de que a atuação docente, como construção humana, não está dissociada de fatores socioculturais que a determinam ao mesmo tempo em que são por ela afetados.

Apesar da recorrente impressão de que o trabalho do professor é individual e único junto aos alunos, não há como desprezar o contexto histórico e social em que ele e os discentes encontram-se inseridos, tampouco o modo como sua ação repercute em cada estudante e na comunidade educativa e social como um todo. Logo, a forma como o docente concebe o conhecimento não está isolada da maneira como o apresenta ao aluno (transposição didática), nem dos resultados do processo educativo a curto e longo prazo.

Paralelamente, cada fenômeno humano está articulado a múltiplas determinações, que ultrapassam o simples acúmulo de partes, constituindo-se em um fluxo de permanentes transformações. Desse modo, o desenvolvimento humano não é linear, cumulativo e sucessivo; pelo contrário, nossa história se desenvolve entre contradições, geradas nos conflitos inerentes às relações humanas e à realidade.

Com base nesses princípios, reconhecemos que tanto os docentes quanto a prática pedagógica sempre se constituem de modo articulado na relação com o aluno, em que o tempo e o espaço determinam - e são reciprocamente determinados - pela construção do processo educativo. Nessa perspectiva, compreendendo a ação docente de modo interativo e necessariamente contextualizado, este estudo pretende focar o trabalho pedagógico, concretizado em intervenções e práticas pedagógicas. Assim, ao compreender as concepções e a prática docente como esferas de um todo maior, articulado, pretendemos encontrar os elos que sustentam a práxis pedagógica, buscando elementos que dialogam no processo de transposição didática.

Para tanto, pretendemos estudar as práticas pedagógicas que se dão em classes de alfabetização ( $1^{\circ}$ e $2^{\circ}$ anos do Ensino Fundamental) de uma escola municipal de São Paulo em suas relações com as concepções docentes; mais especificamente, trata-se de compreender o que ocorre em sala de aula em relação às propostas de ensino da escrita, bem como averiguar quais encaminhamentos as orientam, a fim de focar no processo de aprendizagem da língua.

Para essa investigação, assumimos como referenciais teóricos os princípios construtivistas e postulados histórico-culturais. 
Para tanto, iniciamos o presente estudo com a apresentação, no primeiro capítulo, do panorama do ensino da língua escrita no Brasil, enfocando mais especificamente o direito à educação e à alfabetização no cenário das políticas públicas que devem garanti-lo.

No segundo capítulo, são abordadas as concepções de aprendizagem que subsidiam o ensino, avaliando suas implicações para a prática docente.

O terceiro capítulo destina-se à investigação acerca das concepções sobre a língua escrita, bem como à compreensão dos possíveis modos de articulação entre esses paradigmas e as práticas de ensino da língua escrita, mais precisamente, ao processo de transposição didática que ocorre quando os objetos culturais se transformam em objetos de conhecimento.

O quarto capítulo busca compreender o papel das interações em sua relação com o processo de aprendizagem e de construção da língua escrita.

No quinto capítulo, é delineada a proposta de pesquisa em si, situando o problema a ser investigado, as circunstâncias em que ocorre, bem como a metodologia de coleta de dados.

O sexto e sétimo capítulos apresentam a escola e as turmas estudadas, buscando caracterizar tanto o contexto mais geral em que esta pesquisa se desenvolve, quanto as especificidades atreladas às classes e aos professores observados.

No oitavo capítulo, é traçado o percurso construído, delineando os passos que seguimos ao proceder à análise dos dados coletados.

No nono e décimo capítulos, é realizada a análise dos dados. A partir das informações colhidas durante as entrevistas e das observações realizadas nas duas turmas ( $1^{\circ}$ e $2^{\circ}$ ano), focaremos cada eixo de investigação, quais sejam: a linguagem, o ensino e aprendizagem, e as interações (tomados tanto pelas concepções docentes, como pelas práticas pedagógicas). Por essa via, pretendemos contribuir para uma melhor compreensão das relações entre a teoria e a prática docente.

O décimo primeiro capítulo destina-se à conclusão da pesquisa, momento em que se busca recapitular a hipótese, comparar posturas, avaliar a progressão pedagógica na escola analisada e tecer respostas, ainda que provisórias, sobre as questões que motivaram o presente estudo. Fica aí o desafio de uma possível contribuição: delinear implicações para a formação docente e para os próprios rumos da educação. 


\section{POLÍTICAS PÚBLICAS E ENSINO DA LÍNGUA}

Há muito, o direito à educação - e, mais especificamente à alfabetização - é reconhecido no cenário das políticas públicas. Com o objetivo de assegurar que o ensino da língua seja garantido a todos os brasileiros, ao longo do tempo, diversas iniciativas vêm sendo tomadas; no entanto, os próprios índices oficiais demonstram que ainda temos muito que caminhar para alcançar as metas a que nos propomos.

\subsection{Sobre os direitos à educação e ao processo de alfabetização}

No relatório "Educação, um tesouro a descobrir" (UNESCO, 2010), redigido pela Comissão Internacional sobre Educação para o século XXI, a UNESCO ${ }^{1}$ aponta a relevância da educação ante os desafios que o futuro nos reserva. No documento, a Comissão explicita como, por intermédio desta, ainda é possível combater a pobreza e investir na capacitação de pessoas, a fim de que desenvolvam habilidades e possibilidades de se lançar com confiança ao porvir. Ressalta também que, para tanto, é preciso que os indivíduos possam construir-se continuamente, desenvolver capacidades de refletir e de agir, bem como assumir o papel que thes cabe como trabalhadores e cidadãos, tomando consciência de si e do mundo que os rodeia.

Perante os múltiplos desafios suscitados pelo futuro, a educação
surge como um trunfo indispensável para que a humanidade tenha a
possibilidade de progredir na consolidação dos ideais da paz, da
liberdade e da justiça social. [...] No desfecho de seus trabalhos, a
Comissão faz questão de afirmar sua fé no papel essencial da
educação [...] como uma via a serviço de um desenvolvimento humano
mais harmonioso e autêntico, de modo a contribuir para a diminuição
da pobreza, da exclusão social, das incompreensões, das opressões,
das guerras [...] No final de um século marcado pelo tumulto e pela
violência, assim como pelo progresso econômico e científico - aliás,
desigualmente distribuído - e no alvorecer de um novo século, cuja
perspectiva é alimentada por um misto de angústia e de esperança, é
imperativo que todos aqueles que estejam investidos de
responsabilidade prestem atenção aos fins e aos meios da educação.
(UNESCO, 2010, p. 05)

Aqui, é importante pensar sobre um dilema que, há muito, apresenta-se no âmbito educacional, e, mais especificamente para o presente estudo, no ensino da língua: Educar para quê? Alfabetizar para quê?

\footnotetext{
${ }^{1}$ Organização das Nações Unidas para Educação, Ciência e Cultura.
} 
Colello (2017) ajuda-nos a elucidar a questão quando aponta como, em um mundo regido pela globalização neoliberal, estamos submetidos à dicotomia de dois fóruns diferentes - e não pouco relevantes - que influenciam e ditam parâmetros educacionais.

De um lado, a postura representada pelo Fundo Monetário Internacional (FMI), pela Organização Mundial do Comércio (OMC) e pelo Banco Mundial, a qual defende o ensino técnico voltado para a formação dos trabalhadores competitivos e em condições de se inserir no mercado; de outro, a posição liderada pelo Fórum Mundial de Educação, que, entendendo a educação como um direito social, postula o ensino público financiado pelo Estado, situando o próprio sujeito como alvo da intervenção escolar. (COLELLO, 2017, p. 32)

Portanto, considerar essas tendências é fundamental, uma vez que a concepção de alfabetização compreendida como um direito assume finalidades distintas de quando assumida sob um paradigma vinculado apenas ao mundo do trabalho.

Segundo Brito (apud COLELLO, 2017), a relação entre a educação e o mercado de trabalho advém das demandas próprias do sistema e tem implicações diretas no ensino da língua, o que se observa em diferentes planos:

a) econômico, porque cabe ao trabalhador ter uma participação efetiva no processo produtivo, o que exige o domínio de competências de leitura e de escrita, para poder tomar decisões e lidar com protocolos;

b) social, porque convivemos em contextos fortemente marcados por práticas letradas, o que imprimiu novas formas de relacionamento entre os indivíduos;

c) tecnológico, porque recursos digitais foram incorporados à vida cotidiana, o que intensificou o trânsito no universo linguístico;

d) político, porque a exigência de dominar as práticas letradas se dá em decorrência do próprio sistema capitalista, "que instigou o aumento da produtividade, a formação de mercados consumidores e a assimilação de valores hegemônicos" (BRITO apud COLELLO, 2017, p. 33).

Assim, salienta Colello (2017, p. 34) que posturas educacionais assumidas em conformidade com essa mentalidade têm por objetivo fundamental alfabetizar pessoas economicamente produtivas, o que reverbera em 
(uma) escola voltada para metas utilitárias, o ensino como mero mecanismo de transmissão de conteúdos, o professor movido por propósitos imediatistas, a aprendizagem como instrumentalização dos sujeitos, 0 aluno submetido a propósitos pedagógicos predeterminados, a língua como um conjunto fechado de regras e normas. (COLELLO, 2017, p. 34)

Sob outra perspectiva, o Fórum Mundial de Educação defende a educação como um direito social, em que a preocupação fundamental recai sobre a formação humana. Essa ótica pressupõe uma educação para um mundo mais justo, solidário e que caminhe em direção à paz e à igualdade de direitos, sem, contudo, que isso anule a preparação do indivíduo para o mundo do trabalho.

Em consonância com esse princípio, a referida autora destaca a contribuição de outros estudiosos, que postulam que a educação "é um direito, não uma mercadoria" (CHARLOT apud COLELLO, 2017, p. 34), devendo atingir objetivos amplos, como "a formação para a cidadania, o respeito aos direitos humanos, o desenvolvimento sustentável e a formação do pensamento crítico" (CHARLOT apud COLELLO, 2017, p. 35). Para tanto, as iniciativas pedagógicas precisam promover o desenvolvimento de "competências, isto é, a mobilização de recursos cognitivos e afetivos para o enfrentamento de situações complexas" (PERRENOUD apud COLELLO, 2017, p. 35).

Do mesmo modo, o educador deve considerar que, "ao lado da aprendizagem de fatos e conceitos, os conteúdos escolares incorporem princípios, atitudes, valores e procedimentos (COLL; MONEREO apud COLELLO, 2017, p. 35), ou seja, que "a aprendizagem (esteja) vinculada às práticas sociais" (SOARES apud COLELLO, 2017 , p. 35) e que "o ensino, simultaneamente, respeite o ponto de vista dos alunos e atenda aos apelos no nosso mundo, diminuindo as diferenças sociais" (FERREIRO apud COLELLO, 2017, p. 35).

Ao se reconhecer, pois, a importância da educação, é preciso explicitar também quem deve incumbir-se de tal tarefa, dedicando-se a ela com compromisso e relevância. 
No ano de 2017, a mesma UNESCO redigiu um novo documento, o Relatório de Monitoramento Global da Educação 2017/2018, em que avalia o papel da responsabilização dos sistemas educacionais globais no que diz respeito a atingir a visão do Objetivo de Desenvolvimento Sustentável (ODS) 4 da ONU - "assegurar a educação inclusiva e equitativa de qualidade e promover oportunidades de aprendizagem ao longo da vida para todos" (UNESCO, 2017, p. 7), e lança luz à necessidade de que diferentes instâncias da sociedade se responsabilizem pelo que Ihes cabe para que se deem a universalização da educação e a melhoria do ensino. Nesse sentido,

Responsabilização significa ser capaz de agir quando algo está dando errado, por meio de políticas, leis e defesa (advocacy), inclusive por meio de ombudsmen, para proteger os direitos dos cidadãos. Nós precisamos de mecanismos universais mais fortes para consagrar e garantir o direito à educação e responsabilizar todos os governos por seus compromissos. (UNESCO, 2017, p. 05)

Trata-se, então, de reconhecer que a educação formal é direito de todos, para que possam sentir-se pertencentes ao universo do qual fazem parte. Sendo, portanto, um bem comum e universal, é de responsabilidade prioritária do poder público, o qual não deve medir esforços para universalizá-la em todos os níveis.

Assim, cabe ao Estado, promover um ensino gratuito de boa qualidade aos cidadãos - considerando-se desde a admissão e o atendimento em creches até 0 ingresso em nível superior -, bem como viabilizar o acesso e a continuidade dos estudos aos jovens e adultos que, na idade adequada, não tiveram oportunidade de entrada no ensino regular, além de promover o atendimento a crianças com necessidades especiais.

A despeito da responsabilidade governamental, aqui se faz oportuna a consideração de Soares (2017, p. 14) sobre a relação entre o poder público e o direito à educação:

$\mathrm{Na}$ verdade, o discurso oficial pela democratização da escola, seja na direção quantitativa, seja na direção qualitativa, procura responder à demanda popular por educação, por acesso à instrução e ao saber. A escola pública não é, como erroneamente se pretende que seja, uma doação do Estado ao povo; ao contrário, ela é uma progressiva e lenta conquista das camadas populares em sua luta pela democratização do saber, através da democratização da escola. (SOARES, 2017, p. 14) 
Ao partir, pois, do princípio de que a educação é um direito a ser garantido, cabe neste momento tratar do papel da linguagem na constituição do humano, bem como estabelecer qual é o lugar da aprendizagem da língua nesse processo.

Presumindo que a inserção e a participação humanas no mundo requerem situarmo-nos em relação a ele, a nós mesmos e aos outros, legitimamos o poder que tem a palavra enquanto instrumento de significação e, simultaneamente, "cordão" que nos permite estabelecer relações com nosso eu, com o tu, entre nós e com o universo à nossa volta.

Reconhecer o valor da palavra exige, também, que nos debrucemos sobre seu caráter de permanência na versão escrita. Colello (2007, p. 41) esclarece que, como prática social à qual se atribui diferentes funções, a escrita concretiza o trânsito no tempo e espaço, permitindo ao ser humano criar cultura e "ser por ela criado", em uma relação dialógica que não se esgota.

Entre todas as conquistas do homem, a linguagem é a que mais
contribuiu para fazer dele um ser humano de fato. Na sua relação com
o mundo, é a palavra a melhor representação do potencial simbólico,
capaz de fazer a sutura entre o ser, o indivíduo em particular, a
sociedade e o quadro de referências que se concretiza em cada
objeto, em cada indagação e em cada posicionamento pessoal. A
linguagem garante ao homem o lugar de locutor, a posição de sujeito
que rege a própria vida e reage diante dela [... Se a linguagem é a
maior das invenções humanas, a escrita é a maior conquista da
civilização, razão pela qual ela marca o início da história da
humanidade. Graças às suas características, a escrita promove uma
ruptura com o espaço (interlocução à distância), com o tempo
(permanência do texto como portador autônomo) e com as exigências
dialógicas primárias da interlocução (intercâmbio na ausência do
outro), ampliando indiscutivelmente os limites da existência humana.
(COLELLO, 2007, p. 18-19-21)

Logo, para que cada indivíduo possa constituir-se como pessoa, consciente de si e de seu entorno, com capacidades de refletir e de agir, é imperioso que possa estar imerso e participe efetivamente do universo letrado, âmbito em que a escrita assume caráter humanizador, de bem cultural, capaz de gerar consciência e de ampliar a visão de mundo das pessoas. Somente pelo domínio da palavra escrita é possível fazer valer direitos, exercer a cidadania e interagir com o universo social a que pertence, nas mais variadas instâncias e situações. 
Nesse sentido, dominar a palavra escrita é o mesmo que assumir o controle da própria vida, no sentido de ser autônomo, investido de um poder de e para. Isto porque, se nas civilizações antigas o domínio da escrita era de conhecimento restrito às classes dominantes, pois somente a elas cabia sancionar leis e controlar informações, na sociedade letrada atual, a escrita se apresenta como "ferramenta" do estar e interagir em comunidade. Assim, o domínio da escrita traduz relações de poder, uma vez que pressupõe a competência para lidar com uma tecnologia que permite compreender e expressar-se, inserindo-se e agindo criticamente no grupo ao qual pertence. Falamos, então, de sentidos diferentes de PODER, que revelam dominação ou potência de ação.

E considerando que a escola é o lugar em que se privilegia a transmissão, o posicionamento crítico e a organização e geração de saberes, é propriamente nesse espaço que o domínio das letras e dos demais signos gráficos deve contribuir para a formação de pessoas capazes de ler o mundo, expressar-se e atuar sobre ele. É nesse âmbito que repensar a alfabetização de nossas crianças e jovens se faz necessário.

\subsection{As políticas públicas de educação: entre a intenção e a realidade}

Nossa história mostra que a democratização do ensino não se deu como deveria, e é inegável a necessidade de melhorias na educação brasileira, entendida aqui sob a perspectiva de uma escola de boa qualidade e acessível a todos.

Com esse objetivo, iniciativas governamentais têm sido adotadas visando garantir que todos os alunos do país realizem aprendizagens essenciais na trajetória de sua escolaridade. Embora iniciativas tenham sido adotadas desde a Constituição de 1934, quando foram estabelecidas prioridades para a educação brasileira, ainda não alcançamos as metas educacionais almejadas.

Destacaremos as iniciativas mais recentes que podem contribuir para a análise do problema, apontando inicialmente o Plano Nacional de Educação (PNE), documento oficial que é o principal articulador do Sistema Nacional de Educação (SNE).

O primeiro deles (PNE 2001-2010 - Lei no 10.172, de 09/01/2001) produziu fecundos debates entre a sociedade civil e órgãos governamentais sobre a educação nacional. Esse plano estabeleceu a meta de atingir, no prazo de cinco anos, contados 
a partir do ano de início de sua vigência, o atendimento de toda a população do Ensino Fundamental.

Em 2006, isto é, ano subsequente ao estipulado para a consecução da referida tarefa, dados do Censo Escolar realizado pelo INEP (Instituto Nacional de Estudos e Pesquisas Educacionais Anísio Teixeira) apontavam que a pretendida universalização do acesso ao Ensino Fundamental fora praticamente alcançada.

Contudo, a despeito dos avanços que pretendia alcançar, a viabilização do PNE frustrou-se por vários motivos, tendo como maior entrave a origem e a destinação de recursos financeiros capazes de viabilizar as intenções previstas, pois, como é sabido, uma educação de excelência é dispendiosa.

O governo federal, tendo, pois, vários desafios a vencer, mas assumindo a importância de um plano institucional que direcionasse esforços e investimentos para melhorar a educação no país, aprovou (por meio da Lei no 13.005, de 25/06/2014), o atual PNE, com vigência decenal (2014/2024), o qual definiu as prioridades para o sistema nacional de educação desse período, além dos meios de se acompanhar sua implementação:

De acordo com o Art. 5ำ $\S^{\circ}$ do PNE, "a cada 2 (dois) anos, ao longo do período de vigência deste PNE, o Instituto Nacional de Estudos e Pesquisas Educacionais Anísio Teixeira - INEP publicará estudos para aferir a evolução no cumprimento das metas estabelecidas no Anexo desta Lei, com informações organizadas por ente federado e consolidadas em âmbito nacional, tendo como referência os estudos e as pesquisas de que trata o art. 4o, sem prejuízo de outras fontes e informações relevantes." (OPNE, 2018, p. 01)

Dentre suas diretrizes, o Plano prioriza a erradicação do analfabetismo, a universalização do atendimento escolar, a superação das desigualdades educacionais, com ênfase na promoção da cidadania e na erradicação de todas as formas de discriminação, bem como a melhoria da qualidade da educação. Para tal, definiu vinte metas a serem alcançadas ao longo de seus dez anos de vigência.

Divididas em três blocos, estas objetivam: a garantia do direito à educação básica com qualidade (grupo 1); a redução das desigualdades e a valorização da diversidade (grupo 2); e a valorização dos profissionais da educação (grupo 3). Contudo, o balanço dos anos iniciais de implantação do PNE revela que ainda há muitos desafios a serem vencidos. 
Para os fins pretendidos neste estudo, interessam-nos especialmente algumas das referidas metas do primeiro grupo, quais sejam:

- Meta 2: universalizar o Ensino Fundamental de 9 anos para toda a população de 6 a 14 anos e garantir que pelo menos 95\% dos alunos, até o último ano de vigência do PNE, concluam essa etapa na idade recomendada;

- Meta 3: universalizar até 2016 o atendimento escolar para toda a população de 15 a 17 anos e elevar, até o final do período de vigência do PNE, para 85\% a taxa líquida ${ }^{2}$ de matrículas no Ensino Médio;

- Meta 5: alfabetizar todas as crianças, no máximo, até o final do $3^{\circ}$ ano do Ensino Fundamental;

- Meta 9: elevar a taxa de alfabetização da população com 15 anos ou mais para 93,5\% até 2015 e, até o final da vigência do PNE, erradicar o analfabetismo absoluto e reduzir em $50 \%$ a taxa de analfabetismo funcional.

No tocante às metas 2 e 3 , recenseamentos oficiais demonstram que, ainda que não tenha atingido a totalidade, o sistema público de ensino tem, cada vez mais, conseguido garantir o ingresso de crianças à educação fundamental.

Segundo análise do Observatório do PNE (OPNE, 2018), plataforma online coordenada pelo movimento Todos pela Educação, é possível observar, a partir dos dados da PNAD/IBGE, que desde 2009 houve um crescimento na taxa líquida de matrículas da Educação Básica, tendo superado a marca de 97\% em 2015 - o que é favorável ao cumprimento da meta, possivelmente atingida dentro do período previsto. Dados censitários demonstram que, desse montante, cerca de $82,9 \%$ da população está matriculada nas séries iniciais do Ensino Fundamental em escolas públicas, e, $18 \%$, em escolas privadas.

Segundo o Relatório do $2^{\circ}$ Ciclo de Monitoramento das metas do PNE (INEP, 2018, p. 40), em relação ao indicador 2 A, a meta Brasil é atingir, até 2024, 100\% de alunos matriculados no $1^{\circ}$ ano do Ensino Fundamental. Tal expectativa se justifica uma vez que

${ }^{2}$ A Taxa de Escolarização Líquida representa a razão entre o número de matrículas de alunos com idade prevista para estar cursando determinada etapa de ensino e a população total na mesma faixa etária. 
O Brasil alcançou a marca de $97,8 \%$ das crianças de 6 a 14 anos na escola em 2017 (Gráfico 1), tendo praticamente universalizado o atendimento escolar nessa faixa etária da população. Observa-se que, no período de 2004 a 2017, há duas tendências: a primeira, de crescimento mais rápido, ocorreu entre 2004 e 2012; a segunda, de crescimento menos vigoroso, ocorreu a partir de 2012. A matrícula aos 6 anos tornou-se obrigatória no Brasil com a Lei no 11.274, de 06 de fevereiro de 2006, com prazo para que os municípios, os estados e o Distrito Federal tornassem a lei efetiva até 2010. Em parte, a nova legislação poderia explicar o crescimento mais rápido do indicador de cobertura da população de 6 a 14 anos no período entre 2004 e 2012. Não obstante o avanço, ainda há que se incluir, no Ensino Fundamental, um conjunto de cerca de 600 mil crianças de 6 a 14 anos que se encontram fora da escola e não concluíram essa etapa de ensino, embora a tenham frequentado em algum momento. (INEP, 2018, p. 40)

Tal crescimento fica evidente em dados censitários recentes, que apontam para a possibilidade de ampliar ainda mais o ingresso de crianças no Ensino Fundamental.

Gráfico 1 - Percentual de pessoas de 6 a 14 anos que frequentavam ou já tinham concluído o Ensino Fundamental - Brasil - 2004-2017

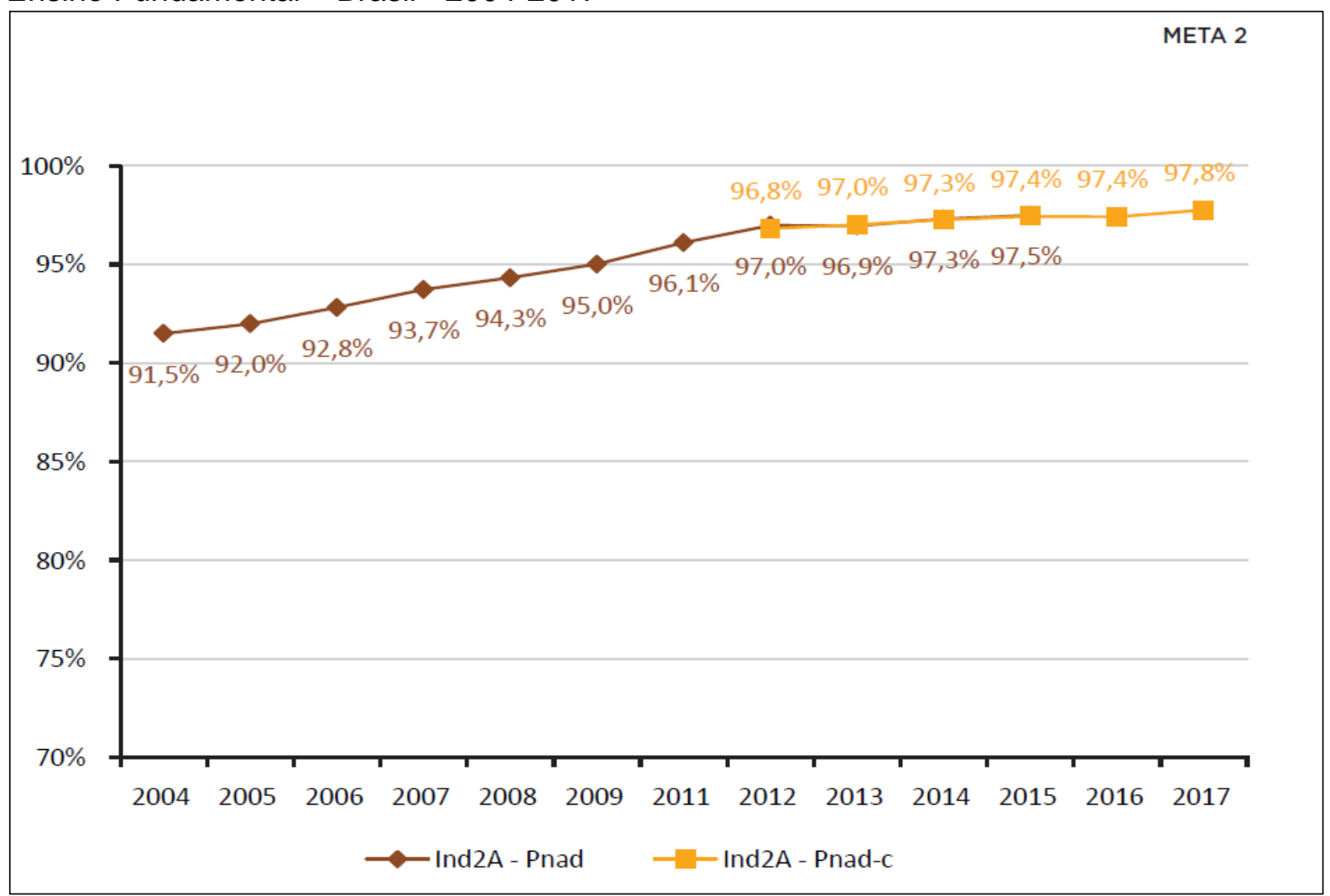

Fonte: INEP (2018)

Contudo, a evasão e a repetência, causadoras também de distorções na idade/série dos alunos que permanecem ou que retornam ao sistema escolar, ainda constituem problemas a serem superados. 
O Censo Escolar 2016, divulgado em fevereiro de 2017, revelou que os anos de investimento ainda não se mostraram suficientes para provocar mudanças significativas nas estatísticas nacionais de educação. As tendências dos anos anteriores permanecem inalteradas e ainda distantes das metas do Plano Nacional de Educação (PNE), conforme é possível observar na avaliação do INEP (2017, s/p).

No Ensino Fundamental, há diferenças expressivas entre as taxas de aprovação por série. Apesar de superiores nos anos iniciais, preocupa a baixa aprovação no $3^{\circ}$ ano, etapa típica de um aluno de 8 anos e no final do ciclo de alfabetização. Praticamente todos os alunos no $1^{\circ}$ ano do Ensino Fundamental estão na idade adequada para a série, independentemente da rede ou da localização da escola. [...] A elevação considerável da distorção idade série no 50 ano mostra que a trajetória dos alunos, já nos anos iniciais, é irregular. A rede privada se destaca como a rede de maior sincronismo idade-série. [...] Os novos dados revelam que $12,9 \%$ e $12,7 \%$ dos alunos matriculados na $1^{\mathrm{a}}$ e $2^{\mathrm{a}}$ série do Ensino Médio, respectivamente, evadiram da escola de acordo com o Censo Escolar entre os anos de 2014 e 2015. O 9o ano do Ensino Fundamental tem a terceira maior taxa de evasão, $7,7 \%$, seguido pela $3^{\text {a }}$ série do Ensino Médio, com 6,8\%. Considerando todas as séries do Ensino Médio, a evasão chega a $11,2 \%$ do total de alunos nessa etapa de ensino. A série histórica revela, em todas as etapas de ensino, uma queda progressiva na evasão escolar de 2007 a 2013, mas o comportamento se altera em 2014, quando as taxas aumentam. A evasão é maior nas escolas rurais, em todas as etapas de ensino. O Pará tem a mais alta taxa de evasão, chegando a $16 \%$ no Ensino Médio. A migração para a Educação de Jovens e Adultos (EJA) é mais expressiva ao final do Ensino Fundamental, quando chega a 3,2\% e 3,1\%, no $7^{\circ}$ e $8^{\circ}$ ano, respectivamente. Em relação à rede de ensino, a migração é maior na rede municipal dos anos finais do Ensino Fundamental, quando alcança uma taxa de $3,8 \%$. No Ensino Médio, a migração é mais expressiva na rede estadual de ensino, com 2,4\%. Já os indicadores de promoção e repetência não são inéditos [...] Entre 2014 e 2015, a repetência na $1^{\underline{a}}$ série do Ensino Médio chega a 15,3\%. O índice também é alto no $6^{\circ}$ ano do Ensino Fundamental, com taxas de 14,4\% de repetência. (INEP, 2017, s/p)

Em consonância e com o objetivo de atender à meta 5 do PNE e alfabetizar todas as crianças até os 8 anos de idade (o que corresponde ao $3^{0}$ ano do Ensino Fundamental I), entidades governamentais e parceiras têm acompanhado os avanços nas políticas públicas de alfabetização no país, divulgando dados e estudos para aferir sua evolução.

Assim, iniciativas da sociedade civil têm se ocupado em acompanhar a situação da população brasileira no que diz respeito ao domínio do mundo letrado. Destacamos 
aqui o Indicador Nacional de Alfabetismo Funcional (INAF), que pode ser compreendido por meio da seguinte descrição:

O Indicador de Alfabetismo Funcional (INAF) é uma pesquisa idealizada em parceria entre o Instituto Paulo Montenegro e a ONG Ação Educativa e realizado com o apoio do IBOPE Inteligência com o objetivo de mensurar o nível de alfabetismo da população brasileira entre 15 e 64 anos, avaliando suas habilidades e práticas de leitura, de escrita e de matemática aplicadas ao cotidiano. [...] O principal objetivo do INAF é oferecer informações qualificadas sobre as habilidades e práticas mensuradas, de modo a fomentar o debate público, estimular iniciativas da sociedade civil, subsidiar a formulação de políticas públicas nas áreas de educação e cultura, além de colaborar para o monitoramento do desempenho das mesmas. (IPM, 2016)

Esse estudo, realizado desde o ano de 2001, busca medir os níveis de alfabetismo da população brasileira, e o faz apresentando habilidades de leitura e de escrita definidas por categorias que têm como parâmetros de avaliação diferentes níveis em escala de proficiência, os quais pressupõem também o domínio das habilidades dos grupos anteriores.

Ao analisar os níveis de Alfabetismo no país, o INAF busca contribuir para a defesa dos direitos educativos dos brasileiros incidindo na agenda acerca do desenvolvimento educacional do país. Assim, coloca em debate o próprio significado de analfabetismo, que não pode se restringir a uma visão binária de alfabetizado $x$ nãoalfabetizado e sim de um processo gradativo de aquisição e consolidação de habilidades. Os instrumentos utilizados na coleta de dados do INAF procuram abarcar a complexidade do fenômeno tanto na dimensão das habilidades cognitivas quanto das práticas sociais nos diversos contextos de vivência dos jovens e adultos entre 15 e 64 anos. Para o INAF, Alfabetismo é a capacidade de compreender e utilizar a informação escrita e refletir sobre ela, um contínuo que abrange desde o simples reconhecimento de elementos da linguagem escrita e dos números até operações cognitivas mais complexas, que envolvem a integração de informações textuais e dessas com os conhecimentos e as visões de mundo aportados pelo leitor. Dentro desse campo, distinguem-se dois domínios: o das capacidades de processamento de informações verbais, que envolvem uma série de conexões lógicas e narrativas, denominada pelo INAF como letramento, e as capacidades de processamento de informações quantitativas, que envolvem noções e operações matemáticas, chamada numeramento. (IPM, 2018, p. 4)

De 2001 a 2005, as pesquisas foram realizadas anualmente, alternando-se o foco entre leitura/escrita e matemática. A partir de 2007, essas duas dimensões foram integradas e, desde então, o levantamento nacional passou a ser feito em intervalos 
mais longos, com edições nos anos de 2009, 2011 e 2015, sendo que sua última edição foi realizada em 2018.

Até o ano de 2011, a escala de interpretação de habilidades definia quatro níveis; no entanto, em 2015, essa classificação foi restruturada com o objetivo de melhor dimensionar os resultados, o que reorganizou os níveis anteriores, que passaram, então, a ser cinco.

Ficaram inalterados os níveis Analfabeto e Rudimentar, que, juntos, definem o Analfabetismo. Já os níveis Básico e Pleno, que compunham o grupo dos Funcionalmente Alfabetizados, foram reorganizados em três, a saber: Elementar, intermediário e Proficiente, tal como se vê no Quadro 1, a seguir:

Quadro 1 - Níveis de Alfabetismo segundo escala INAF - comparativo anterior e posterior à revisão de 2015

\begin{tabular}{|c|c|c|}
\hline \multicolumn{3}{|c|}{ Níveis de Alfabetismo } \\
\hline $\begin{array}{c}\text { Utilizados até } 2011 \\
\text { (4 níveis) }\end{array}$ & GRUPOS & $\begin{array}{c}\text { Utilizados a partir de } 2015 \\
\text { (5 níveis) }\end{array}$ \\
\hline Analfabeto & \multirow{2}{*}{$\begin{array}{l}\text { ANALFABETOS } \\
\text { FUNCIONAIS }\end{array}$} & Analfabeto \\
\hline Rudimentar & & Rudimentar \\
\hline Básico & \multirow{3}{*}{$\begin{array}{l}\text { FUNCIONALMENTE } \\
\text { ALFABETIZADOS }\end{array}$} & Elementar \\
\hline \multirow{2}{*}{ Pleno } & & Intermediário \\
\hline & & Proficiente \\
\hline
\end{tabular}

Fonte: INAF (2018)

No primeiro grupo estão classificados os analfabetos e os que se encontram em grau muito restrito de alfabetização; no segundo, estão as pessoas que apresentam algum nível de alfabetismo funcional, seja este elementar, intermediário ou proficiente no domínio da língua.

Assim, com o intuito de descrever os parâmetros de avaliação nos diferentes níveis, o Quadro 2, a seguir, apresenta as habilidades que os caracterizam. ${ }^{3}$

3 INAF. Indicador de Alfabetismo Funcional. INAF Brasil 2018: resultados preliminares. São Paulo: Ação Educativa; Instituto Paulo Montenegro, 2018. Disponível em: http://acaoeducativa.org.br/wpcontent/uploads/2018/08/Inaf2018_Relat\%C3\%B3rio-Resultados-Preliminares_v08Ago2018.pdf. Acesso em: 10 jul. 2018. Acesso em: 10 jul. 2018. 
Quadro 2 - Escala de proficiência por níveis de alfabetismo

\begin{tabular}{|c|c|}
\hline Grupos & Escala especial para estudo Alfabetismo e mundo do trabalho \\
\hline Analfabeto & $\begin{array}{l}\text { - Corresponde à condição dos que não conseguem realizar tarefas simples } \\
\text { que envolvem a leitura de palavras e frases, ainda que uma parcela } \\
\text { consiga ler números familiares (de telefone, preços etc.). }\end{array}$ \\
\hline Rudimentar & $\begin{array}{l}\text { - Localiza uma ou mais informações explícitas, expressas de forma literal, } \\
\text { em textos muito simples (calendários, tabelas simples, cartazes } \\
\text { informativos) compostos de sentenças ou de palavras que exploram } \\
\text { situações familiares do cotidiano doméstico. } \\
\text { - Compara, lê e escreve números familiares (horários, preços, } \\
\text { cédulas/moedas, telefone), identificando o maior/menor valor. } \\
\text { - Resolve problemas simples do cotidiano envolvendo operações } \\
\text { matemáticas elementares (com ou sem uso da calculadora) ou } \\
\text { estabelecendo relações entre grandezas e unidades de medida. } \\
\text { - Reconhece sinais de pontuação (vírgula, exclamação, interrogação etc.) } \\
\text { pelo nome ou função. }\end{array}$ \\
\hline Elementar & $\begin{array}{l}\text { - Seleciona uma ou mais unidades de informação, observando certas } \\
\text { condições, em textos diversos de extensão média, realizando pequenas } \\
\text { inferências. } \\
\text { - Resolve problemas envolvendo operações básicas com números da } \\
\text { ordem do milhar, que exigem certo grau de planejamento e controle (total } \\
\text { de uma compra, troco, valor de prestações sem juros). } \\
\text { - Compara ou relaciona informações numéricas ou textuais expressas em } \\
\text { gráficos ou tabelas simples, envolvendo situações de contexto cotidiano } \\
\text { doméstico ou social. } \\
\text { - Reconhece significado de representação gráfica de direção e/ou sentido } \\
\text { de uma grandeza (valores negativos, valores anteriores ou abaixo } \\
\text { daquele tomado como referência). }\end{array}$ \\
\hline Intermediário & $\begin{array}{l}\text { - Localiza informação expressa de forma literal em textos diversos } \\
\text { (jornalístico e/ou científico) realizando pequenas inferências. } \\
\text { - Resolve problemas envolvendo operações matemáticas mais complexas } \\
\text { (cálculo de porcentagens e proporções) da ordem dos milhões, que } \\
\text { exigem critérios de seleção de informações, elaboração e controle em } \\
\text { situações diversas (valor total de compras, cálculos de juros simples, } \\
\text { medidas de área e escalas). } \\
\text { - Interpreta e elabora síntese de textos diversos (narrativos, jornalísticos, } \\
\text { científicos), relacionando regras com casos particulares com o } \\
\text { reconhecimento de evidências e argumentos, e confrontando a moral da } \\
\text { história com sua própria opinião ou senso comum. } \\
\text { - Reconhece o efeito de sentido ou estético de escolhas lexicais ou } \\
\text { sintáticas, de figuras de linguagem ou sinais de pontuação. }\end{array}$ \\
\hline
\end{tabular}




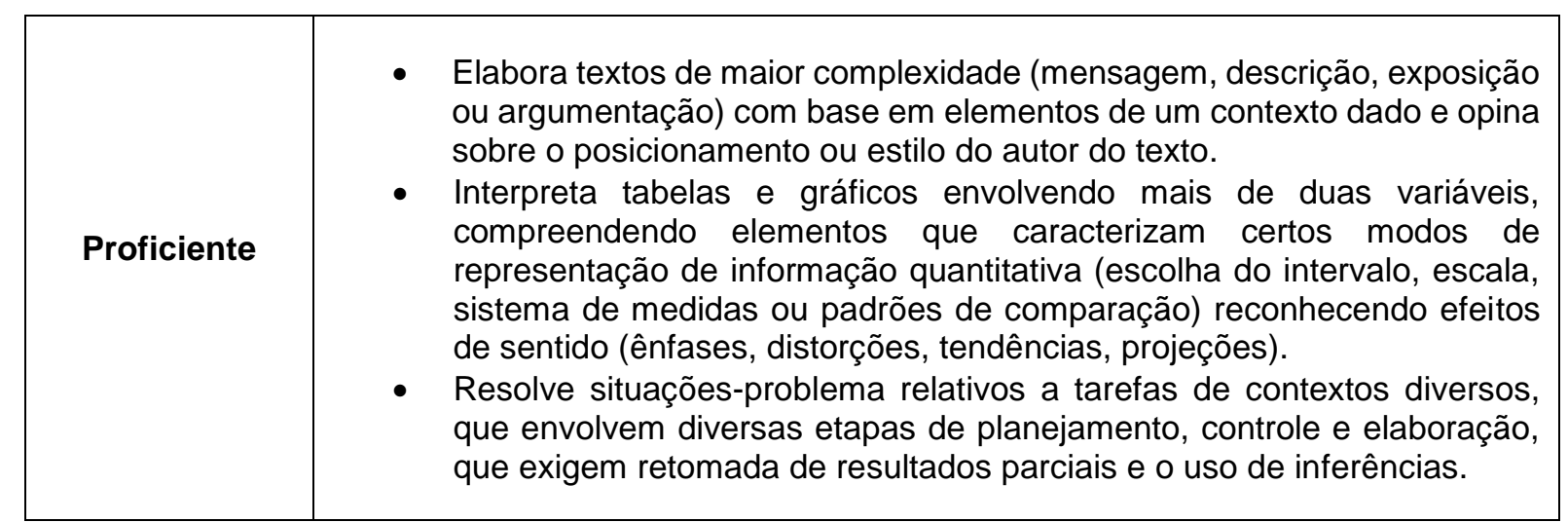

Fonte: INAF (2018)

Conforme a Tabela 1, a seguir, os resultados obtidos ao longo de mais de uma década indicam que cerca de $30 \%$ das pessoas foram classificadas como analfabetas funcionais, sendo apenas $8 \%$ consideradas analfabetas.

O grupo classificado como Rudimentar constitui aproximadamente $22 \%$ dessa população. A quantidade de pessoas consideradas alfabetizadas funcionalmente alcança aproximadamente $70 \%$ dos investigados. A maioria deles encontra-se no nível Elementar (34\%), enquanto 25\% estão na condição Intermediária e apenas 12\% são proficientes, conforme se pode observar na distribuição dos dados.

Tabela 1 - Níveis de alfabetismo no Brasil conforme o INAF (2001-2018)

\begin{tabular}{|c|c|c|c|c|c|c|c|c|c|}
\hline Nível & $\begin{array}{l}2001 \\
2002\end{array}$ & $\begin{array}{l}2002 \\
2003\end{array}$ & $\begin{array}{l}2003 \\
2004\end{array}$ & $\begin{array}{l}2004 \\
2005\end{array}$ & 2007 & 2009 & 2011 & 2015 & 2018 \\
\hline BASE & 2000 & 2000 & 2001 & 2002 & 2002 & 2002 & 2002 & 2002 & 2002 \\
\hline Analfabeto & $12 \%$ & $13 \%$ & $12 \%$ & $11 \%$ & $9 \%$ & $7 \%$ & $6 \%$ & $4 \%$ & $8 \%$ \\
\hline Rudimentar & $27 \%$ & $26 \%$ & $26 \%$ & $26 \%$ & $25 \%$ & $20 \%$ & $21 \%$ & $23 \%$ & $22 \%$ \\
\hline Elementar & $28 \%$ & $29 \%$ & $30 \%$ & $31 \%$ & $32 \%$ & $35 \%$ & $37 \%$ & $42 \%$ & $34 \%$ \\
\hline Intermediário & $20 \%$ & $21 \%$ & $21 \%$ & $21 \%$ & $21 \%$ & $27 \%$ & $25 \%$ & $23 \%$ & $25 \%$ \\
\hline Proficiente & $12 \%$ & $12 \%$ & $12 \%$ & $12 \%$ & $13 \%$ & $11 \%$ & $11 \%$ & $8 \%$ & $12 \%$ \\
\hline Total $^{2}$ & $100 \%$ & $100 \%$ & $100 \%$ & $100 \%$ & $100 \%$ & $100 \%$ & $100 \%$ & $100 \%$ & $100 \%$ \\
\hline $\begin{array}{l}\text { Analfabeto } \\
\text { Funcional* }\end{array}$ & $39 \%$ & $39 \%$ & $37 \%$ & $37 \%$ & $34 \%$ & $27 \%$ & $27 \%$ & $27 \%$ & $29 \%$ \\
\hline $\begin{array}{l}\text { Funcionalmente } \\
\text { Alfabetizados* }\end{array}$ & $61 \%$ & $61 \%$ & $63 \%$ & $63 \%$ & $66 \%$ & $73 \%$ & $73 \%$ & $73 \%$ & $71 \%$ \\
\hline
\end{tabular}

Nota: O critério de arredondamento das frações dos resultados permite percentuais totais diferentes da soma dos números arredondados.

Fonte: INAF (2018) 
Dentre outras constatações, esses índices revelam que

Os Analfabetos Funcionais - equivalentes, em 2018, a cerca de 3 em cada 10 brasileiros - têm muita dificuldade para fazer uso da leitura e da escrita e das operações matemáticas em situações da vida cotidiana, como reconhecer informações em um cartaz ou folheto ou ainda fazer operações aritméticas simples com valores de grandeza superior às centenas. [...] Nos três estudos realizados entre $2009 \mathrm{e}$ 2015, o percentual de Funcionalmente Alfabetizados ficou estável em $73 \%$ para, em 2018, apresentar uma pequena oscilação negativa. Em síntese, apenas 7 entre 10 brasileiros e brasileiras entre 15 e 64 anos podem ser considerados Funcionalmente Alfabetizados conforme a metodologia do INAF pela estimativa de 2018. (IPM, 2018, p. 8)

Com o objetivo de acompanhar as políticas públicas no que concerne à alfabetização, o MEC dispõe de instrumentos oficiais que compõem o Sistema de Avaliação da Educação Básica (SAEB), dentre os quais, cabe destacarmos a Avaliação Nacional de Alfabetização (ANA), utilizada pela primeira vez em 2013.

Trata-se de uma avaliação anual censitária destinada a todos os alunos matriculados no $3^{\circ}$ ano do Ensino Fundamental. A prova aplicada busca aferir nos estudantes os níveis de alfabetização e de letramento em Língua Portuguesa (leitura e escrita) e em Matemática, e também a analisar as condições de escolaridade que esse estudante teve - ou não - para desenvolver esses saberes.

A avaliação constitui-se ainda como instrumento utilizado para acompanhar a eficácia do Pacto Nacional pela Alfabetização na Idade Certa (PNAIC), segundo o qual estar alfabetizado implica em poder

Interagir por meio de textos escritos em diferentes situações; significa ler e produzir textos para atender a diferentes propósitos. A criança alfabetizada compreende o sistema alfabético de escrita, sendo capaz de ler e escrever, com autonomia, textos de circulação social que tratem de temáticas familiares a ela. (PNAIC, p. 12)

A ANA permite a análise do sistema escolar como um todo, servindo, portanto, para pautar a definição de ajustes nas políticas públicas buscando a melhoria da alfabetização. A formulação do material e sua aplicação são de responsabilidade do Instituto Nacional de Estudos e Pesquisas Educacionais Anísio Teixeira (INEP), que também recolhe e divulga os dados obtidos.

Nessa perspectiva, a fim de aferir os níveis de alfabetização e de letramento em Língua Portuguesa, a ANA definiu categorias gradativas de proficiência, buscando 
analisar os resultados obtidos em escrita e em leitura. Quanto à escrita, foram delineados os níveis constantes no Quadro 3, a seguir. ${ }^{4}$

4 ANA. Avaliação Nacional da Alfabetização. Documento Básico. 2013. Disponível em: http://download.inep.gov.br/educacao_basica/saeb/2013/livreto_ANA_online.pdf. Acesso em: 08 jul. 2018 
Quadro 3 - Descrição da escala de proficiência de escrita

\begin{tabular}{|c|c|c|c|}
\hline Níveis & & & Descrição dos níveis \\
\hline 1 & Elementar & \multirow{3}{*}{ INSUFICIENTE } & $\begin{array}{l}\text { Em relação à escrita de palavras, os estudantes } \\
\text { posicionados neste nível provavelmente estabelecem } \\
\text { algumas correspondências entre as letras grafadas e a } \\
\text { pauta sonora, e não escrevem palavras } \\
\text { alfabeticamente. Em relação à produção de textos, os } \\
\text { estudantes produzem textos ilegíveis ou não escrevem } \\
\text { o texto. }\end{array}$ \\
\hline 2 & Elementar & & $\begin{array}{l}\text { Em relação à escrita de palavras, os estudantes que se } \\
\text { encontram neste nível provavelmente escrevem } \\
\text { ortograficamente palavras de estrutura silábica mais } \\
\text { simples e escrevem palavras mais complexas com } \\
\text { trocas ou omissão de letras, alterações na ordem das } \\
\text { letras e outros desvios ortográficos. Em relação à } \\
\text { produção de textos, não escrevem textos ou produzem } \\
\text { textos ilegíveis. }\end{array}$ \\
\hline 3 & Elementar & & $\begin{array}{l}\text { Em relação à escrita de palavras, os estudantes que se } \\
\text { encontram neste nível provavelmente escrevem } \\
\text { palavras com diferentes estruturas silábicas, } \\
\text { particularmente marcados pela presença da estrutura } \\
\text { consoante-vogal, apresentando dificuldades em sílabas } \\
\text { com estrutura mais complexa. Em relação à produção } \\
\text { de textos, escrevem textos incipientes ou inadequados } \\
\text { ao que foi proposto ou produzem fragmento de uma } \\
\text { narrativa, sem conectivos e/ou recursos de substituição } \\
\text { lexical e/ou pontuação para estabelecer articulações } \\
\text { entre partes do texto. Apresentam, ainda, grande } \\
\text { quantidade de desvios ortográficos e erros de } \\
\text { segmentação ao longo do texto. }\end{array}$ \\
\hline 4 & Adequado & SUFICIENTE & $\begin{array}{l}\text { Em relação à escrita de palavras, os estudantes } \\
\text { posicionados neste nível provavelmente escrevem de } \\
\text { forma ortográfica palavras com diferentes estruturas } \\
\text { silábicas. Em relação à produção de textos, atendem à } \\
\text { proposta de escrita de dar continuidade a uma } \\
\text { narrativa, embora possam não contemplar todos os } \\
\text { elementos da narrativa e/ou partes da história a ser } \\
\text { contada. Articulam as partes do texto, com a utilização } \\
\text { de conectivos, recursos de substituição lexical e outros } \\
\text { articuladores, embora cometam desvios que } \\
\text { comprometem sentidos parciais da narrativa, inclusive } \\
\text { por não utilizar a pontuação ou utilizar os sinais de } \\
\text { modo inadequado. Cometem alguns desvios } \\
\text { ortográficos e de segmentação que não comprometem } \\
\text { a compreensão do texto. }\end{array}$ \\
\hline
\end{tabular}




\begin{tabular}{|l|l|l|}
\hline \multirow{5}{*}{5} & Desejável & $\begin{array}{l}\text { Em relação à escrita de palavras, os estudantes } \\
\text { posicionados neste nível provavelmente escrevem de } \\
\text { forma ortográfica palavras com diferentes estruturas } \\
\text { silábicas. Em relação à produção de textos, atendem à } \\
\text { proposta de dar continuidade a uma narrativa, e } \\
\text { produzem textos legíveis. Produzem narrativas com } \\
\text { todas as fases do enredo, situação central e situação } \\
\text { final, articulando as partes do texto com conectivos, } \\
\text { recursos de substituição lexical e outros articuladores } \\
\text { textuais. Segmentam e escrevem as palavras } \\
\text { corretamente, embora possam cometer alguns desvios } \\
\text { ortográficos e de pontuação que não comprometem o } \\
\text { sentido do texto. }\end{array}$ \\
\hline
\end{tabular}

Igualmente, no tocante à leitura, foi definida a seguinte escala: 
Quadro 4 - Descrição da escala de proficiência de leitura

\begin{tabular}{|c|c|c|c|}
\hline Nível & & & Descrição do nível \\
\hline 1 & Elementar & & $\begin{array}{l}\text { - Ler palavras dissílabas, trissílabas e } \\
\text { polissílabas com estruturas silábicas } \\
\text { canônicas, com base em imagem. } \\
\text { - Ler palavras dissílabas, trissílabas e } \\
\text { polissílabas com estruturas silábicas não } \\
\text { canônicas, com base em imagem. }\end{array}$ \\
\hline 2 & Básico & INSUFICIENTE & $\begin{array}{l}\text { - Identificar a finalidade de textos como convite, } \\
\text { cartaz, texto instrucional (receita) e bilhete. } \\
\text { - Localizar informação explícita em textos curtos } \\
\text { (com até cinco linhas) em gêneros como piada, } \\
\text { parlenda, poema, tirinha (história em } \\
\text { quadrinhos em até três quadros), texto } \\
\text { informativo e texto narrativo. } \\
\text { - Identificar o assunto de textos, cujo assunto } \\
\text { pode ser identificado no título ou na primeira } \\
\text { linha em gêneros como poema e texto } \\
\text { informativo. } \\
\text { - Inferir o assunto de um cartaz apresentado em } \\
\text { sua forma estável, com letras grandes e } \\
\text { mensagem curta e articulação da linguagem } \\
\text { verbal e não verbal. }\end{array}$ \\
\hline 3 & Adequado & \multirow[t]{2}{*}{ SUFICIENTE } & $\begin{array}{l}\text { - Inferir o assunto de texto de divulgação } \\
\text { científica para crianças. } \\
\text { - Localizar informação explícita, situada no meio } \\
\text { ou final do texto, em gêneros como lenda e } \\
\text { cantiga folclórica. } \\
\text { - Identificar o referente de um pronome pessoal } \\
\text { do caso reto em gêneros como tirinha e poema } \\
\text { narrativo. } \\
\text { - Inferir relação de causa e consequência em } \\
\text { gêneros como tirinha, anedota, fábula e texto } \\
\text { de literatura infantil. } \\
\text { - Inferir sentido com base em elementos verbais } \\
\text { e não verbais em tirinha. } \\
\text { Reconhecer significado de expressão de } \\
\text { linguagem figurada em gêneros como poema } \\
\text { narrativo, texto de literatura infantil e tirinha. }\end{array}$ \\
\hline 4 & Desejável & & $\begin{array}{l}\text { - Inferir sentido de palavra em texto verbal. } \\
\text { - Reconhecer os participantes de um diálogo em } \\
\text { uma entrevista ficcional. } \\
\text { - Inferir sentido em texto verbal. } \\
\text { - Reconhecer relação de tempo em texto verbal. } \\
\text { - Identificar o referente de pronome possessivo } \\
\text { em poema. }\end{array}$ \\
\hline
\end{tabular}

Fonte: SAEB/ANA, 2018 
Segundo apontam dados da ANA 2016, terceira e última edição a ser aplicada pelo MEC, o cenário educacional brasileiro é preocupante no que tange aos resultados de alfabetização dentro das metas desejáveis, conforme mostram os resultados relativos aos níveis de escrita e de leitura dessa edição ${ }^{5}$.

Gráfico 2 - Resultados - Proficiência Escrita Brasil 2016

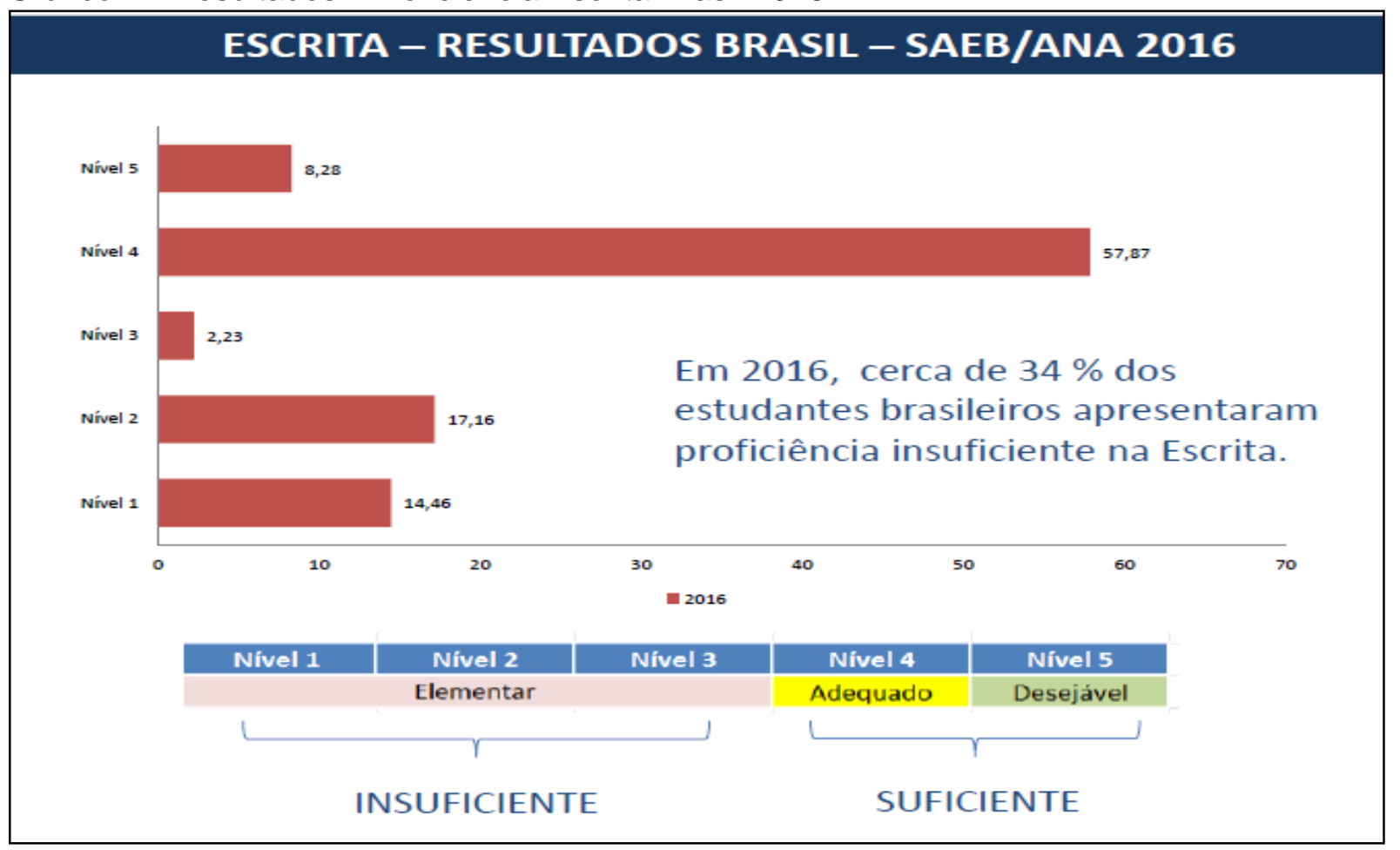

Fonte: SAEB/ANA, 2018

${ }^{5}$ SAEB/ANA. Sistema de Avaliação da Educação Básica/ Avaliação Nacional da Alfabetização. Edição 2016. Disponível em: http://portal.inep.gov.br/educacao-basica/saeb/sobre-a-ana. Acesso em: 10 jul. 2018. 
Quanto à leitura, também se verifica a necessidade de avanços, conforme se pode observar no Gráfico 3.

Gráfico 3 - Resultados - Proficiência Leitura Brasil 2016

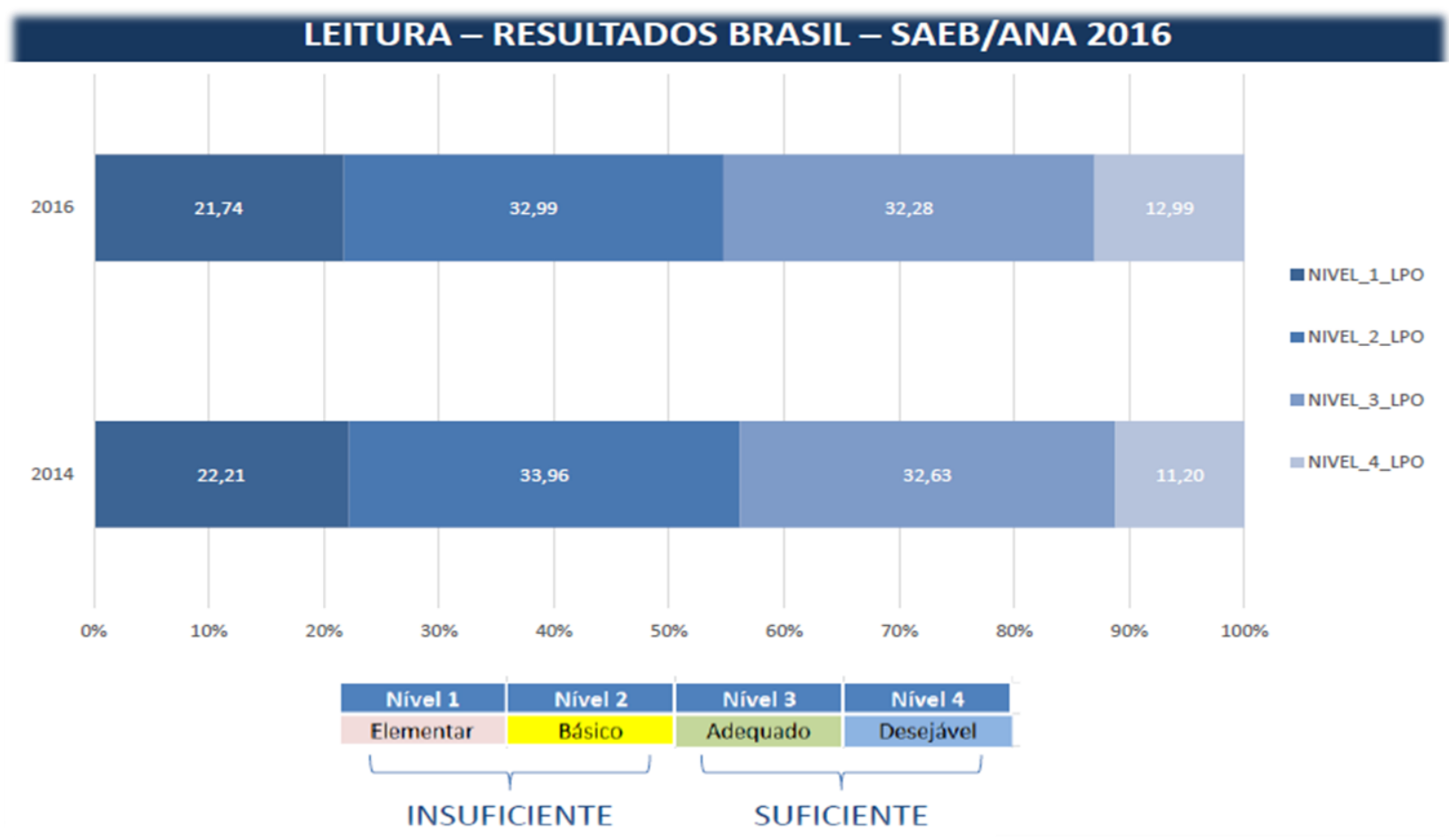

Fonte: SAEB/ANA, 2018

Como se pode verificar, os níveis de alfabetização dos brasileiros em 2016 são praticamente os mesmos obtidos em 2014, uma vez que o desempenho dos estudantes do $3^{\circ}$ ano do Ensino Fundamental matriculados em escolas públicas permaneceu estatisticamente o mesmo.

Os resultados revelam ainda que parte considerável dos estudantes, mesmo havendo passado por três anos de escolarização, apresentam níveis de proficiência insuficientes para a idade. A terceira edição da ANA foi aplicada pelo Inep entre 14 e 25 de novembro de 2016. Foram avaliadas 48.860 escolas, 106.575 turmas e 2.206.625 estudantes. (MEC, 2017)

Ainda com o objetivo de alcançar a meta 5 e de alfabetizar todas as crianças até os 8 anos de idade, os governos Federal, do Distrito Federal, dos Estados e dos Municípios firmaram, em 2012, compromisso com o Pacto Nacional pela Alfabetização na Idade Certa (PNAIC), formalizando um conjunto integrado de ações (programas de formação, materiais e referenciais curriculares e pedagógicos) junto ao Ministério da Educação (PNAIC, 2012). 
No entanto, em dezembro de 2017, o tempo previsto pelo Ministério da Educação para a alfabetização das crianças foi alterado, passando de três para dois anos, tendo sido estabelecidos o primeiro e o segundo anos do Ensino Fundamental como os anos em que a alfabetização deve ocorrer. Tal mudança se deu por motivo da promulgação da Base Nacional Comum Curricular (BNCC) ${ }^{6}$, já prevista na Lei de Diretrizes e Bases da Educação Nacional (LDB, Lei no 9.394/1996) e aprovada pelo Conselho Nacional de Educação (CNE).

Vale destacar aqui que, quando promulgada, a BNCC apresentava consonância com a perspectiva enunciativo-discursiva de linguagem, e reconhecia a alfabetização como apropriação da língua a partir das práticas sociais e nos processos de interação entre os sujeitos. Por essa razão, os textos, em contextos reais de circulação, assumiam centralidade no trabalho.

Em estreita sintonia com os princípios da BNCC, foi lançada em outubro de 2017 a Política Nacional de Alfabetização (PNA), a qual estabelecia como diretrizes para o alfabetismo os pressupostos de alfabetização em contextos de uso, articulando as práticas socais de linguagem às propostas de análise do sistema alfabético de escrita.

Nessa perspectiva, com o objetivo de melhor alcançar a meta 5 do PNE, em função desse cenário, em 22 de fevereiro de 2018, por meio da Portaria nำ142, 0 Ministério da Educação instituiu e publicou o Programa Mais Alfabetização.

O Programa Mais Alfabetização é uma estratégia do Ministério da Educação para fortalecer e apoiar as unidades escolares no processo de alfabetização dos estudantes regularmente matriculados no $1^{\circ}$ ano e no $2^{\circ}$ ano do Ensino Fundamental. [...] Surgiu como estratégia do Ministério da Educação diante dos resultados da Avaliação Nacional da Alfabetização - ANA, do Sistema de Avaliação da Educação SAEB, criada com o intuito de avaliar o nível de alfabetização dos estudantes ao final do 3ํano do Ensino Fundamental, apontou uma quantidade significativa de crianças nos níveis insuficientes de alfabetização (leitura, escrita e matemática). [...] O Programa Mais Alfabetização cumpre a determinação da Base Nacional Comum Curricular - BNCC (Resolução CNE/CP nำ 2, de 22 de dezembro de 2017), quando diz que, nos dois primeiros anos do Ensino Fundamental, a ação pedagógica deve ter como foco a alfabetização, a fim de garantir amplas oportunidades, para que os alunos apropriemse do sistema de escrita alfabética, de modo articulado ao

\footnotetext{
${ }^{6}$ A BNCC é um documento de caráter normativo; define as aprendizagens essenciais que todos os alunos devem desenvolver ao longo das etapas e das modalidades da Educação Básica, norteando o currículo dos sistemas e redes de ensino e as propostas pedagógicas de todas as escolas públicas e privadas de Educação Infantil, Ensino Fundamental e Ensino Médio, em todo o Brasil.
} 
desenvolvimento de outras habilidades de leitura e de escrita e ao seu envolvimento em práticas diversificadas de letramentos. (MEC, 2018, p. 3-4)

Contudo, em 11 de abril de 2019, contrariando os estudos e as diretrizes anteriores em que se embasavam as políticas públicas de alfabetização, o governo do Estado instituiu nova PNA (Decreto o 9.765), cuja abordagem retoma a centralidade dos métodos de alfabetização, enfatizando o método fônico, bem como as habilidades de codificação e decodificação como centrais no processo de aprendizagem da escrita e da leitura.

Segundo essa normativa, as práticas sociais de linguagem, bem como as hipóteses construídas pela criança ao pensar sobre a escrita são delegados a segundo plano, uma vez que as novas diretrizes assumem como referência os princípios das ciências cognitivas da leitura e das neurociências, e não mais os marcos dialógicos e interacionais dos postulados construtivistas e históricoculturais.

Uma alfabetização baseada em evidências traz para o debate sobre o ensino e a aprendizagem da leitura e da escrita a visão da ciência, dados da realidade que já não podem ser ignorados nem omitidos. Entre os ramos das ciências que mais contribuíram nas últimas décadas para a compreensão dos processos de leitura e de escrita, está aquele que se convencionou chamar ciência cognitiva da leitura (SNOWLING; HULME, 2013; ADAMS, 1990; DEHAENE, 2011). Por ciências cognitivas se designa o campo interdisciplinar que abrange as diferentes disciplinas que estudam a mente e sua relação com o cérebro, como a psicologia cognitiva e a neurociência cognitiva. (PNA, p. 20)

A despeito dos esforços empreendidos e das mudanças nas diretrizes, os dados apresentados demonstram que o Brasil ainda se encontra distante das metas educacionais desejáveis a uma sociedade democrática. Ainda que o ingresso ao ensino regular tenha se ampliado, a qualidade da formação escolar permanece em desequilíbrio, não garantindo que todos tenham as mesmas oportunidades. As marcas da desigualdade permanecem, o que, com efeito, interfere nas possibilidades de desempenho escolar, na participação social, assim como na inserção do sujeito no universo do trabalho, cada vez mais atrelado aos conhecimentos científico e tecnológico. Isso porque as oportunidades educacionais também variam conforme o 
contexto cultural em que o aluno vive, seu nível de renda e a origem étnica e social a que pertence.

Além disso, problemas de outras naturezas também afetam o ensino na escola: a descontinuidade de políticas públicas vinculadas à educação, a ingerência na gestão e na distribuição de recursos para a educação e a má formação dos professores são questões que interferem na educação formal, levando o poder público a deixar de cumprir a contento o seu dever de promover um ensino de qualidade para todos.

Entendemos que o cenário apresentado esboça uma tentativa de compreensão dos motivos pelos quais a empreitada da democratização da alfabetização ainda não se concretizou, apesar do avanço ocorrido nos conhecimentos a respeito da língua e dos mecanismos de cognição. Daí a relevância de se propor pesquisas que possam aprofundar a compreensão das práticas em sala de aula, como é o caso do presente estudo.

Assim, tomando como ponto de partida as concepções docentes sobre a língua (o que ensinamos quando ensinamos a ler e escrever) e sobre o processo de aprendizagem, pretendemos estudar as práticas de ensino e os modos de interação em sala de aula; para tanto, nos capítulos a seguir, empreenderemos esforço em compreendê-las mais profundamente no contexto da realidade escolar na intenção de subsidiar a revisão de posturas pedagógicas e, assim, avançar na construção de uma escola mais justa e equânime para todos. 


\section{CONCEPÇÕES DE APRENDIZAGEM}

Compreender o modo como o indivíduo aprende e de que maneira constrói conhecimentos tem sido uma preocupação desde a Antiguidade grega e faz parte da ocupação de pesquisadores de diferentes áreas. Dentre elas, destaca-se a Psicologia, que, assim como outras ciências, advém do pensamento filosófico e procura entender os fenômenos psicológicos e as maneiras de ver a realidade e compreender o mundo. A esse respeito, Castanho (2011, p. 15) esclarece

Pode parecer tarefa simples falar sobre aprendizagem, uma vez que
ela faz parte de nossa experiência cotidiana. Estamos sempre
aprendendo. Aprender é um processo fundamental na sobrevivência
do homem e em sua adaptação ao meio circundante, não só do ponto
de vista de sua natureza biológica, mas principalmente como
decorrência de sua capacidade de organização simbólica da
realidade. (CASTANHO, 2011, p. 15)

Desde há muito, diversas concepções sobre o conhecimento coexistem no tempo e representam diferentes modos de interpretar a aprendizagem humana. Vale a pena, aqui, distinguir conhecimento e aprendizagem em uma perspectiva que aponta para a diferenciação, mas entende que ambos os processos estão relacionados e se complementam, sendo impossível tratar um sem mencionar o outro, bem como abordar a aprendizagem sem mencionar as raízes conceituais que a sustentam.

No entanto, apesar das divergências que guardam entre si, as diferentes conceitualizações teóricas sobre aprendizagem têm em comum o fato de abordarem a relação entre esta e o desenvolvimento, bem como entre cultura e educação. Nesse sentido, compreender o modo como as pessoas aprendem implica também entender em que condições o fazem e a partir de quais situações - o que nos leva ao papel do “outro" nesse processo.

Com a intenção de compreender essas relações, recorremos aos pressupostos epistemológicos $^{7}$ das correntes em que tais conceitualizações são elaboradas. A epistemologia investiga a natureza, as etapas e os limites do conhecimento humano, ou, mais precisamente, nas palavras de Tesser (1995, p. 92): "podemos considerar a epistemologia como o estudo metódico e reflexivo do saber, de sua organização, de

\footnotetext{
${ }^{7}$ Etimologicamente; "epistemologia" significa discurso (logos) sobre a ciência (episteme). (Episteme + logos). (TESSER, 1995, p. 91).
} 
sua formação, de seu desenvolvimento, de seu funcionamento e de seus produtos intelectuais. A epistemologia é o estudo do conhecimento".

No âmbito escolar, é preciso analisar a tríade sujeito que aprende, situação de aprendizagem e professor, considerando a dinâmica que aí se dá, o que, em outras palavras, constitui a prática educativa própria da Pedagogia, uma vez que esta, "como teoria da educação, busca equacionar, de alguma maneira, o problema da relação educador-educando, de modo geral, ou, no caso específico da escola, a relação professor-aluno, orientando o processo de ensino e aprendizagem." (SAVIANI, 2005, p. 1).

Na mesma linha de pensamento, Castanho (2011, p. 16) observa que a aprendizagem é essencial para que o indivíduo construa conhecimento, uma vez que este é amplo, cumulativo e resultante dos processos de aprendizagem. Logo, para entender essa relação, aponta que é preciso partir da questão sobre como o indivíduo aprende e constrói conhecimentos tendo em vista os elementos implicados nessa relação. A esse respeito, merecem destaque

três elementos básicos implicados na tentativa de resposta à questão sobre como o homem aprende e constrói conhecimento: o objeto (suposta realidade a ser conhecida), representação do objeto (diferentes formas como o objeto se fazem conhecido) e sujeito do conhecimento (quem conhece). O primeiro diz respeito à indagação do real, da possibilidade de o homem chegar ao conhecimento e à verdade das coisas, o que implica alguns questionamentos sobre o objeto a ser conhecido: simples ou complexo? Universal ou particular? Aparência ou essência? O segundo diz respeito às possibilidades de representação do objeto: inata ou adquirida? A priori ou a posteriori? Individual ou coletiva? Por último, as questões sobre quem é o sujeito: razão ou emoção? Dotado de estruturas prévias ou uma tábula rasa que depende de experiências para conhecer? Ativo ou passivo? (CASTANHO, 2011, p. 17, grifo do autor)

Tendo em vista essa relação, é importante partir do princípio de que toda prática pedagógica se sustenta em concepções de aprendizagem, mesmo quando estas não estão explícitas. Embasadas em pressupostos epistemológicos, e ancoradas em visões de mundo e de homem, tais concepções não são neutras, uma vez que, a partir delas, são delineados diretrizes, objetivos educacionais e processos de avaliação, bem como se procede às escolhas metodológicas que guiam a prática educativa.

Assim, tendo por base princípios epistemológicos, diferentes referenciais teóricos são construídos, o que permite identificar distintas linhas conceituais que se articulam à prática docente. A ação pedagógica desencadeada pelo professor 
"dependerá, fundamentalmente, de sua concepção de aprendizagem. Porque, tendo consciência disso ou não, todo o ensino se apoia em uma concepção de aprendizagem." (WEISZ; SANCHEZ, 2002, p. 22).

Tratar, pois, de concepções de aprendizagem implica em observar sua relação com o conhecer. A esse respeito, Not (1993, p. 35) aclara que:

\begin{abstract}
Aprender é construir representações e desenvolver comportamentos. Estes servirão para construir, reconstruir ou transformar, material ou simbolicamente (sobretudo pela linguagem), os conteúdos de nosso universo material, social ou cultural. As representações são construções do mundo (inclusive de nós mesmos) e das ações cujo objeto podem ser os conteúdos do mundo. O conjunto constitui o conhecimento, que é ação ou representação, em potência ou em atos. Conhecer, enfim, é saber, isto é, poder ajustar uma ação aos objetos aos quais ela se refere, aos fins desejados e às situações nas quais se age, ou ainda poder tornar presente a ideia de um objeto de pensamento. (NOT, 1993, p. 35)
\end{abstract}

Ao se pensar nas diversas relações possíveis entre o que se conhece (o objeto), quem conhece (o sujeito) e de que maneira este o faz (o modo como cria representações sobre o objeto), fica evidente a complexidade do tema, o que justifica porque formulações simplistas não têm condições de responder ao problema da fundamentação das práticas escolares. Assim, ao longo do tempo, diferentes pesquisas teóricas valorizaram, de distintos modos, a relação entre objeto e sujeito de conhecimento, enfatizando ora um, ora outro, havendo, ainda, linhas que destacaram a interação entre as perspectivas do sujeito e do objeto.

Entretanto a realidade, que é muito mais rica, dinâmica e complexa do que qualquer classificação a que possamos chegar, reverbera na prática pedagógica, igualmente viva e multifacetada. Nesse contexto, é possível constatar como os professores não se "encaixam" completamente em uma ou em outra teoria, o que lhes causa, muitas vezes, desorientação e incertezas.

Do mesmo modo, vale lembrar aqui a consideração de Weisz e Sanchez (2002, p. 34), quando estes apontam que

nenhuma pedagogia responde apenas a um modelo psicológico embora a ausência de um modelo psicológico claro resulte em um modelo psicológico ambíguo", como destaca o clássico postulado de Sêneca: "não há vento favorável para quem não sabe para onde vai. (WEISZ; SANCHEZ, 2002, p. 34) 
A explicitação das linhas teóricas que subsidiam a prática docente justifica-se não apenas para fazer justiça à complexidade do fazer pedagógico, como também para fundamentar um posicionamento crítico imprescindível para as tomadas de decisão no âmbito político-pedagógico. No caso da presente pesquisa, essa explicitação serve também para balizar os princípios de análise. Para tanto, buscamos agrupar as linhas teóricas de modo a representar as diferentes tendências: inatismo, empirismo e construtivismo.

Por entendermos também que as concepções de aprendizagem são, conforme já apontamos, tributárias de outras conceitualizações, os princípios de análise que assumimos estão embasados nas mesmas dimensões filosófica (concepções de mundo e homem), psicológica (concepções a respeito do homem que aprende), pedagógica (concepções de educação que abordam a relação entre ensino e aprendizagem) e linguística (concepções sobre a língua e seu ensino).

\subsection{Concepções fixista de mundo e essencialista de homem}

Partindo de uma perspectiva filosófica, Matui (1995, p. 3) aponta como relevantes duas concepções de mundo que se opõem.

A primeira, denominada fixista, surgiu do idealismo e da contemplação gregos ${ }^{8}$, e recebeu confirmação no "mito da criação", em todo o período medieval. Corresponde a uma leitura de mundo e de sociedade concebidos como imutáveis, já que estes não se sujeitam à transformação e à mudança.

Essa visão considera que as coisas foram criadas acabadas, de uma vez por todas. O céu e a Terra e tudo o que neles há foram criados já acabados e independentes. Para essa visão, mesmo as espécies animais são hoje o que foram no passado, sem terem sofrido nenhuma mutação. (MATUI, 1995, p. 4)

Também conhecida como metafísica, essa visão busca a essência das coisas, isto é, seu aspecto imutável e eterno, em oposição ao que aparentam. Metafísica significa "aquilo que vem depois da física", da aparência externa. (MATUI, 1995, p. 5).

\footnotetext{
${ }^{8}$ Refere-se ao Olimpo, onde tudo era inalterável, uma vez que perfeito, sendo a perfeição sinônimo de permanência e imutabilidade.
} 
De acordo com o modo metafísico de pensar, só é "verdadeiro o que está por trás e além do concreto". Por isso, essas teorias abstraem as relações de causa e consequência que levam às mudanças, pois entendem que estas são irreais por fazerem parte apenas das aparências.

Em decorrência dessa visão, emerge uma percepção maniqueísta do mundo, uma vez que, sendo imutáveis, os seres podem ser separados e classificados em bons e maus. Assim, vistos dicotomicamente, acabam por serem concebidos como uma coisa ou outra, e não como uma coisa e outra.

A postura filosófica que corresponde à natureza humana em uma concepção fixista é o essencialismo, que entende o homem nascido com uma essência predeterminada, a qual define quem ele é e como vai estar e agir no mundo. Ao nascer, sua ação já está previamente estabelecida por seu modo de ser, já que os valores que o norteiam estão inscritos em sua essência, a qual precede a existência.

\subsubsection{Implicações do fixismo e do essencialismo}

Buscando compreender quem é o ser que aprende e como o faz, encontramse duas correntes pedagógicas que, alinhadas ao fixismo e ao essencialismo, vão ao encontro de teorias fundamentais de aprendizagem que atualmente ainda exercem forte influência na atuação docente: o inatismo e o empirismo. Embora partam de pressupostos contrários, ambas as visões apresentam um conceito estático de sujeito do conhecimento, entendendo-o ora como aquele que deve apreender um mundo pronto - ao qual o indivíduo é apresentado (empirismo), ora desenvolvendo-se de acordo com sua essência, igualmente predeterminada e inalterável (inatismo).

\section{a) Inatismo}

A visão inatista, também conhecida por racionalismo, idealismo, apriorismo ou preformismo, tem suas origens no pensamento racional da Antiguidade grega, em que se buscavam explicações baseadas em conceitos, e não mais em mitos, a fim de explicar o mundo. Essa ótica teve como precursor Platão (427-347 a.C.), e, posteriormente, na Modernidade, o filósofo e matemático René Descartes (15961650). Segundo Platão,

o ser humano já trazia, desde o nascimento, as ideias dos objetos que a alma teria contemplado antes de nascer, no mundo das ideias verdadeiras. Assim, também o racionalismo moderno considera que 
existem "ideias inatas" [...] necessárias e suficientes para apreender e compreender todas as coisas deste mundo. Se podemos pensar clara e logicamente em um objeto é porque ele existe. [...] No racionalismo, o sujeito confere ao objeto o conhecimento prévio que traz consigo. (MATUI, 1995, p. 36-37)

Na mesma linha de argumentação, Macedo (2002) aponta que, de acordo com essa visão, o que somos, em termos de inteligência, já está definido ao nascer, de modo que o desenvolvimento independe de nossos esforços pessoais ou dos ensinamentos que recebemos, uma vez que dons, habilidades e aptidões dos sujeitos são programados por herança genética. Assim, cabe a nós apenas descobrir, desvendar nossas capacidades e qualidades inerentes, que nos são reveladas ao longo da vida.

O autor acrescenta que a visão inatista apresenta uma concepção heterônoma de inteligência, já que esta tem limites que regulam a conduta do indivíduo e o impedem de ir além do que suas capacidades the permitem.

Logo, há uma dissociação entre o sujeito (passivo e subordinado à sua préformação ou herança genética) e as experiências vividas, devendo o ambiente submeter-se às limitações da inteligência, estruturalmente organizada.

Isso posto, cabe indagar: como o inatismo se concretiza em sala de aula?

Sob essa perspectiva, em relação à aprendizagem, cabe ao professor ajustar o ambiente e as proposições didáticas de acordo com os potenciais e as limitações dos alunos, aceitando cada um como é. A esse respeito, Becker (2012) aclara que, nessa concepção, o professor deve interferir o mínimo possível no desenvolvimento do aluno, pois este já possui saberes, os quais apenas precisa trazer à consciência. Para que isso ocorra, cabe ao docente, no máximo, auxiliar o aluno, despertando o conhecimento que, de certa forma, já existe potencialmente nele. Ademais, observa que, aqui, "confunde-se desenvolvimento cognitivo com maturação biológica" e acrescenta que "as ações espontâneas farão a criança transitar por fases de desenvolvimento cronologicamente fixas, chamadas de 'estágios', frequentemente confundidos com 'as etapas' da epistemologia genética piagetiana, [...] que variam em função do meio social. (BECKER, 2012, p. 18).

Em decorrência da estrutura pré-formada de inteligência, essa visão valoriza a mensuração por avaliações qualitativas em relação ao quociente intelectual; tal verificação permite diagnosticar as potencialidades que são passíveis de desenvolvimento, bem como antecipar o quanto um indivíduo pode apreender e o que 
poderá ser desenvolvido conforme as limitações que apresenta. Em consonância com essas constatações, também é possível fazer uma seleção, isto é, classificar as pessoas de acordo com suas capacidades ou dons na realização de tarefas e, assim, distribuí-las em grupos específicos de trabalho.

A aceitação passiva e conformada das potencialidades de cada um, muitas vezes erroneamente concebida como "respeitosa", frequentemente funciona como um mecanismo de discriminação e de controle, pois submete os alunos a um destino aprioristicamente traçado. Ainda que o faça de modo inconsciente, ao renunciar à intervenção no processo de aprendizagem do aluno e, desta forma, assumir uma pedagogia espontaneísta e não diretiva, esse professor acaba por exercer um poder predatório e perverso.

Essa mesma epistemologia, que concebe o ser humano como dotado de um saber "de nascença" ou uma capacidade inata, conceberá, também, dependendo das conveniências, um ser humano desprovido da mesma capacidade, "deficitário". Esse "déficit", porém, não é concebido como originário de uma causa externa, mas como hereditário. Onde se detecta maior incidência de dificuldades ou retardos na aprendizagem? Entre os miseráveis, os malnutridos, os pobres, os marginalizados... Está, ali, a teoria da carência cultural para garantir a interpretação de que marginalização socioeconômica e déficit cognitivo são sinônimos. A criança marginalizada, entregue a si mesma, em uma sala não diretiva, produzirá, com alta probabilidade, bem menos em termos de conhecimento, que uma criança da classe média ou alta. Trata-se aqui, de acordo com o apriorismo, de déficit herdado, epistemologicamente legitimado, portanto. [...] A aprendizagem de alguns será explicada como mérito ou talento, e a não aprendizagem de muitos, como déficit herdado, impossível de ser superado. (BECKER, 2012, p. 19-20)

A esse respeito, Davis e Oliveira (2010) mencionam que a posição inatista apoia-se em um entendimento equivocado de contribuições da biologia, tais como a teoria evolucionista de Darwin, a Embriologia e a Genética, não levando em consideração o papel do ambiente sobre o ciclo de vida dos membros de cada espécie, nem a influência da experiência individual de cada um, no caso da espécie humana, especificamente. Em um paralelo com a cultura popular, podemos afirmar que a esta concepção se aplica o ditado "pau que nasce torto, morre torto!".

Se na concepção inatista a essência humana traz em si todas as qualidades e capacidades básicas (ou a falta delas) do ser humano - sua personalidade, seus valores, hábitos, crenças, modos de pensar, reações emocionais e conduta social -, 
na concepção empirista, essa essência é igualmente fixa e predeterminada, mas se revela vazia no momento do nascimento.

\section{b) Empirismo}

Matui (1995) aponta que, sob a ótica empirista, a mente da criança é uma "tábula rasa", ou seja, uma tábua que ainda não foi inscrita. Seria, portanto, somente ao longo da vida que os conhecimentos viriam a ser "depositados" na mente das pessoas, o que ocorreria por meio das experiências e dos estímulos do ambiente. Isso porque, consoante essa visão, o conhecimento vem do objeto (meio físico ou social), sendo recebido passivamente pelo sujeito, por meio de sensações e experiências.

Santomauro (2010, p. 7) ressalta que os pressupostos da corrente empirista também têm sua origem na Antiguidade grega, mais especificamente nas considerações de Aristóteles (384-322 a.C.), que afirmava que "a apreensão das formas perfeitas do mundo das ideias se encarnava a partir do contato dos sujeitos com as formas da realidade física" (SANTOMAURO, 2010, p. 7). Os princípios dessa linha de raciocínio ganharam força na Idade Moderna (séculos XVI e XVII), tendo como expoentes Francis Bacon (1561-1626), Thomas Hobbes (1588-1679) e John Locke (1632-1704).

Ao esclarecer a visão comportamentalista, Giusta (2013) salienta que o conceito de aprendizagem emergiu das investigações empiristas em Psicologia, tendo por base a ideia de que todo conhecimento provém da experiência. Daí o sujeito ser moldável pelas impressões do mundo que, captadas pelos sentidos, associam-se umas às outras e, assim, dão lugar ao conhecimento.

Ao se fazer um paralelo com a cultura popular, o princípio da introdução do conhecimento de fora do sujeito para dentro dele poderia ser traduzido por um ditado muito conhecido e há tempos arraigado pelo senso comum: "água mole em pedra dura, tanto bate até que fura!".

O associacionismo tem por expressão mais solene o behaviorismo, cuja meta era a construção de uma psicologia "científica", fundada em uma metodologia "materialista" capaz de garantir a objetividade só alcançada pelas ciências da natureza. Com o intuito de construir uma ciência do comportamento, Skinner, grande expoente dessa corrente teórica, preocupou-se em medir, comparar, testar, experimentar, prever e controlar os eventos de modo a explicar o desenvolvimento da inteligência. 
A objetividade perseguida pelo behaviorismo é a mesma do positivismo em geral, e por isso, termos como consciência, inconsciente e similares foram banidos da linguagem psicológica. A psicologia vem definida como a "ciência do comportamento" (observável) e o comportamento é entendido como produto das pressões do ambiente, significando o conjunto de reações e estímulos, reações essas que podem ser medidas, previstas e controladas. Nessa via de interpretação, ganha sentido a definição de aprendizagem como "mudança de comportamento resultante do treino ou da experiência". (GIUSTA, 2013, p. 3)

Segundo Macedo (2002), de acordo com essa visão, o desenvolvimento da inteligência é causal e dependente, pois advém da soma das aprendizagens que o indivíduo faz a partir das estimulações externas (positivas, quando reforçam comportamentos que se deseja obter, e, negativas, quando procuram inibir comportamentos desfavoráveis). A ênfase está nos benefícios da experiência, sendo preciso criar hábitos, rotinas e procedimentos favoráveis em um ambiente que estimule o que é positivo e afaste ou puna o que é negativo, devendo-se valorizar as metas predefinidas delineadas por regras que delimitam ou definem o que deve ou não ser feito.

Ao partir do pressuposto de que os homens tendem a maximizar o prazer e a minimizar a dor, os ambientalistas buscavam controlar o comportamento por meio de estímulos, uma vez que entendiam o indivíduo como alguém extremamente reativo à ação do meio. Assim, as mudanças no comportamento poderiam ser provocadas de diferentes modos.

As consequências positivas são chamadas de reforçamento e provocam um aumento da frequência com que o comportamento aparece. [...] Já as consequências negativas recebem o nome de punição e levam a uma diminuição na frequência com que certos comportamentos ocorrem. [...] Quando um comportamento é absolutamente inadequado e se considera desejável eliminá-lo, [...] usa-se o procedimento dito de extinção. Nele, o objetivo é quebrar o elo que se estabeleceu entre o comportamento visto como indesejável e determinadas consequências do mesmo. Para tanto, é preciso que se retire do ambiente as consequências que o mantém. [...] Mais recentemente, outros teóricos afirmaram que o comportamento humano também se modifica em função da observação de como agem outras pessoas, que se tornam modelos a serem copiados. Quando os comportamentos dos modelos são reforçados, tende-se a imitá-los, e quando são punidos, procura-se evita-los. [...] Quando um comportamento for associado a um determinado estímulo, ele tende a reaparecer quando estiverem presentes estímulos semelhantes. Esse fenômeno é chamado de generalização. (DAVIS; OLIVEIRA, 2010, p. 38 , grifos do autor) 
Com base no pressuposto da generalização, é possível afirmar que o Empirismo está pautado em uma perspectiva heterônoma de inteligência, uma vez que seu desenvolvimento depende da pressão ou do trabalho de um adulto sobre a criança, ao policiar sua conduta e punir seus erros na intenção de extingui-los. Esse controle é obtido pela associação de um comportamento a algo positivo ou negativo, de tal modo que, por meio da repetição, um padrão ou norma de conduta seja fixado. Em consonância com esse princípio, Davis e Oliveira (2010, p. 37) afirmam que "determinados fatores se encontram associados a outros, de modo que é possível, ao se identificar tais associações, controlá-las pela manipulação."

Assim, o desenvolvimento da inteligência decorre de duas fontes, a saber: uma interna, de base perceptiva, que possibilita a experiência pela perspectiva sensorial; e outra externa, que associa conceitos relacionados àquilo experimentado pelos sentidos. Na relação com a criança, cabe ao adulto corrigir ou confirmar comportamentos, modelando-a conforme o que é valorizado socialmente ou ao que é necessário para que realize uma tarefa.

Mas como esses princípios se concretizam em sala de aula?

Considerando que, assim como a visão inatista, o empirismo atualmente ainda tem forte influência no cenário educacional, é preciso questionar as consequências da perspectiva comportamentalista. A fim de respondermos à essa questão, recorremos a Becker (2012), que aponta que, sob essa perspectiva, o conhecimento é transmitido verbalmente ao aluno pelo professor, que "dá aula", pois, supostamente, ele tudo sabe, ao passo que a criança nada conhece. É precisamente o professor quem representa o mundo para a criança, e o aluno aprende somente se for ensinado por ele, que exige que memorize os conteúdos, mesmo que o aluno não os tenha entendido. "Como é essa aula? O professor fala, o aluno escuta. O professor dita, e o aluno copia. O professor decide o que fazer e, em geral, decide o mesmo de sempre, e o aluno executa. O professor 'ensina', e o aluno 'aprende'." (BECKER, 2012, p. 14).

Para ter o controle da aprendizagem do aluno, o professor deve manter uma disciplina rígida, bem como proceder a uma avaliação acumulativa e certificadora da adequada aprendizagem, criando instrumentos para se verificar a diferença entre o que a criança tinha antes e o que terá depois do reforço de suas atitudes, sendo o produto de suas ações o recurso qualificador das aquisições que faz.

Davis e Oliveira (2010), de acordo com essas considerações, esclarecem que, ao se enfatizar novas aprendizagens por meio da manipulação dos estímulos que 
antecedem e sucedem o comportamento, é preciso planejar as condições ambientais mais favoráveis à aprendizagem.

Acerca desse aspecto, é possível afirmar que a introdução das teorias empiristas, de certa forma, contribuiu para o trabalho em sala de aula, uma vez que chamou a atenção dos educadores para a importância do planejamento, que deve ocorrer a partir da clareza de objetivos e da previsão de sequências de atividades organizadas a fim de atingi-los. Essa visão também valorizou o papel do professor, em oposição à postura inerte na vertente inatista.

Por outro lado, esses modelos também tiveram efeitos nocivos à prática pedagógica, pois corroboraram um entendimento tecnicista da educação, colocando os projetos de aula como uma fórmula-padrão, abandonando, assim, a reflexão filosófica do educar. Cabendo ao professor a tarefa de conhecer cada vez melhor o "como ensinar", diluía-se a prioridade de pesquisar sobre em que condições a aprendizagem do aluno se dá, tampouco sobre como a criança raciocina.

Outra crítica que igualmente pode ser feita é em relação ao fato de o ambientalismo entender o homem como um alguém totalmente passivo, que pode ser manipulado e controlado pela simples alteração das situações em que se encontra. Por essa razão, vale apontar ainda a desvalorização das situações em que a aprendizagem pode ocorrer de modo espontâneo.

A esta altura, e a partir do já exposto, na intenção de retomar o fio condutor da reflexão tecida até o momento, vale resgatar a perspectiva filosófica em que se sustentam as concepções de aprendizagem aqui assumidas.

\subsection{Concepções transformista de mundo e relacionista de homem}

Voltando à perspectiva filosófica, retomamos Matui (1995), que aborda uma segunda corrente sobre a visão de mundo denominada Transformismo. De acordo com essa concepção, o Universo está em constante mudança, em um movimento evolucionista e dialético.

A sucessão da vida de todas as espécies vegetais e animais, através dos períodos e gerações, comprova que o movimento não atinge apenas os elementos chamados inanimados, mas também o cerne da vida. [...] Todo movimento é transformação. [...] Os aspectos mais notáveis para a visão transformista são as mudanças qualitativas. As transformações não se fazem apenas por acréscimo de quantidades, mas também por saltos de qualidade. (MATUI, 1995, p. 7) 
O entendimento de que o mundo não é estático nem concluído sob uma forma definida sustentou uma mudança também na concepção de homem, dada pela compreensão de que não há uma essência humana determinada desde o nascimento, pois o homem seria constituído ao longo de sua existência. O mundo e seus objetos (inclusive os aspectos sociais) não existem para a criança ao nascer, visto que são construídos por meio do relacionamento entre eles enquanto o próprio sujeito se constitui. Assevera o autor que "ao mesmo tempo e, pelo fato de formar o 'eu' e o sentimento de 'mim', formam-se também o objeto externo e o 'tu'." (MATUI, 1995, p. 12).

Sob a perspectiva do relacionismo, ao contrário do essencialismo, a existência precede a essência, uma vez que o ser humano é tido como mutável e incompleto, inacabado até o momento de sua morte.

Assim, o homem se forma no e pelo relacionamento, bem como a inteligência; esse processo constitui a hominização dos indivíduos que, pela interação entre si e com o meio, formam sua consciência, tornam-se sujeitos da história e criam cultura.

\subsubsection{Implicações pedagógicas do transformismo e do relacionismo}

Para os interacionistas, as teorias inatistas se equivocavam por desprezarem o papel do ambiente, e, as empiristas, por ignorarem os fatores da maturação. Em uma visão interacionista, portanto, organismo e meio exercem ação recíproca, o que acarreta modificações tanto em um, quanto em outro.

Essa mudança de paradigmas orientou as visões de mundo (do fixismo para transformismo) e de natureza humana (do essencialismo para relacionismo) e, igualmente, reverberou nas concepções sobre a aprendizagem e o conhecimento, modificando o panorama da educação, que buscava superar as visões inatista e empirista.

Como consequência da suplantação das perspectivas reducionistas que embasavam a educação, alinham-se as correntes construtivistas e histórico-culturais. Mas, em que consistem essas abordagens?

No âmbito das concepções interacionistas, compreendendo a relevância de suas contribuições para a educação, destacamos duas correntes teóricas: o construtivismo psicogenético; e a abordagem histórico-cultural. 


\section{a) Construtivismo psicogenético}

O construtivismo psicogenético teve como maior expoente Jean Piaget (18961980). Nascido na Suíça, foi biólogo de formação, mas, destacou-se também como pesquisador da Psicologia e da Filosofia, contribuindo significativamente para 0 avanço das reflexões no campo da Educação. A importância da teoria piagetiana decorre, de um lado, da influência exercida pelas sólidas pesquisas que realizou, principalmente no que se refere à compreensão da origem e desenvolvimento da inteligência, e, por outro, do volume de estudos por ele organizados e sistematizados.

Com o objetivo de compreender de que maneiras o homem constrói conhecimento, Piaget dedicou-se a investigar a gênese e o processo de evolução do pensamento, estudando o nascimento e o desenvolvimento das estruturas lógicas do sujeito a partir da interação deste com o objeto de aprendizagem.

Gouveia (2011, p. 119-120) afirma que "o próprio Piaget define sua teoria como Epistemologia Genética, na medida em que busca a origem do conhecimento científico e do pensamento lógico e racional."

Inspirado na Filosofia, particularmente nos pressupostos de Immanuel Kant (1724-1804), Piaget empreendeu esforços na elaboração de referenciais teóricos novos, capazes de superar a dicotomia dos trabalhos realizados em sua época, calcados em concepções antagônicas e reducionistas. Assim, o construtivismo proposto por ele se sustenta no interacionismo de Kant, aliado às óticas genética e transformista. Sob essa perspectiva, sujeito e objeto não são separados, pois constituem uma só estrutura que existe e se articula pela interação recíproca.

Considerando simplista e enganoso se pensar o conhecimento enfatizando ora o papel do sujeito (no inatismo), ora o do objeto (no empirismo), Kant apontava que o conhecimento se dá na relação entre sujeito e objeto, situação em que ambos são ativos, uma vez que o objeto entra com a matéria do conhecimento, enquanto o sujeito entra com a forma.

Pela intuição, o sujeito recebe as impressões do mundo exterior, a matéria, sob a forma de sensações. As categorias ou instrumentos a priori (isto é, anteriores ao objeto) são o tempo e o espaço. Pelo entendimento, o sujeito trabalha essas impressões, fornecendo os conceitos que dão a forma aos objetos. As categorias a priori do entendimento que agem nesse caso são: quantidade, qualidade, relação, modalidade. (FREITAG, 1990, p. 57) 
Na obra piagetiana, pode-se observar dois momentos: inicialmente, postulando que o conhecimento não é totalmente inerente ao próprio sujeito, nem provém da absorção de saberes, o autor dedicou-se a explicitar o processo de desenvolvimento do pensamento, apontando que o conhecimento se constrói por intermédio das interações do sujeito com o meio, salientando que "estar cada vez mais inteligente" depende tanto das estruturas cognitivas, quanto das relações interacionais; em um segundo momento, apontou que a maturação biológica e a ação da criança sobre os objetos são fatores essenciais para o desenvolvimento da inteligência. Com capacidade de aprender construindo ativamente conhecimentos, a criança constituise, desde o nascimento, um "sujeito epistêmico" ou "sujeito cognoscente". Gouveia (2011, p. 124-126) explica que, nessa concepção, Piaget referiu-se ao homem como um "ser que conhece", isto é, um ser pleno de possibilidades que, durante toda a vida, avança na construção de conhecimentos, em uma progressão de relações mentais cada vez mais complexas.

Sob essa ótica, Macedo (2002, p.123 -125) ressalta que, ao desenvolver sua inteligência, o homem pode relacionar-se com os objetos, as pessoas, as tarefas, o espaço e o tempo, de modo interdependente e reversível, uma vez que "os elementos interagem em um contexto sistêmico, sendo partes e todo ao mesmo tempo". Assim sendo, as regulações da inteligência favorecem um contínuo aperfeiçoamento que permite confirmar, compensar, corrigir, substituir e operar, antecipando ou précorrigindo uma ação antes mesmo de sua realização. Esse trabalho é realizado por uma razão imanente à própria inteligência, que procura a todo tempo evoluir.

Piaget buscou a gênese do conhecimento adotando uma postura teóricometodológica própria, a qual caracterizou o método clínico-experimental, que se fundamenta no diálogo entre o pesquisador e a criança, justificando suas ações e afirmações por meio da linguagem.

O método piagetiano de pesquisa não consiste em medir a competência intelectual, mas sim, em compreender como o indivíduo formula suas concepções sobre o mundo que o cerca, como resolve problemas, como explica fenômenos naturais. Esse método prevê a formulação de problemas abertos, chamados provas operatórias, e a solicitação para que a criança os solucione, dando início a diálogos entre pesquisador e pesquisado. (CUNHA, 2008, p. 3)

Segundo Palangana (2015), a postura teórico-metodológica de sua obra pode ser melhor compreendida quando consideramos também sua formação em biologia, 
o que o levou a transferir aspectos dessa ciência para a concepção psicogenética. Dentre esses aspectos, é possível destacar o ajustamento de estruturas antigas a novas funções e o desenvolvimento de novas estruturas para atender a funções antigas, o que caracteriza um movimento contínuo em que cada função se liga a uma base preexistente, ao mesmo tempo em que se altera para se ajustar às novas exigências do ambiente.

A essa dinâmica Piaget denominou "adaptação", conceito que, juntamente com o de "estrutura", permitiram-Ihe construir uma teoria que considera a inteligência uma característica biológica do ser humano, e que tem por função permitir ao indivíduo sobreviver ao ambiente, adaptando-o e se adaptando a ele.

$\mathrm{Na}$ ótica de Piaget, a adaptação é invariável e universal, e nos permite responder às demandas do meio. Para que ocorra, dois processos se dão: a assimilação e a acomodação.

A esse respeito, Davis e Oliveira (2010) esclarecem que, ao entrar em contato com uma nova possibilidade orgânica ou característica do ambiente, há uma ruptura na harmonia entre organismo e meio, o que causa um desequilíbrio. Dois mecanismos são, então, acionados na tentativa de alcançar novamente o equilíbrio: a assimilação, pela qual o organismo, sem alterar suas estruturas, desenvolve ações que visam, a partir das experiências anteriores, atribuir significação aos elementos com os quais interage; e a acomodação, situação em que o organismo é obrigado a se modificar a fim de se ajustar às demandas externas.

Desse modo, a assimilação incorpora a realidade exterior à organização do sujeito, enquanto a acomodação, pelo contrário, transforma o sujeito em função da realidade exterior.

Tais princípios conduziram Piaget à conclusão de que o progresso cognitivo ocorre pela reorganização da própria inteligência, e não pelo acúmulo de conhecimentos.

O estudo da inteligência sensório-motora ou prática [que ocorre] durante os dois primeiros anos do desenvolvimento ensinou-nos como a criança, tendo assimilado primeiro, diretamente, o meio exterior à sua própria atividade, constitui em seguida, para prolongar essa assimilação, um número crescente de esquemas simultaneamente mais móveis e mais aptos a coordenarem-se entre si. (PIAGET, 1963, p. 7) 
Assim, ao investigar o modo como a lógica infantil se transforma em lógica adulta, Piaget partiu de uma concepção de desenvolvimento calcada em um processo contínuo de trocas entre o sujeito e o ambiente; trocas estas que provocam constantes desequilíbrios e equilibrações. A esse movimento constante Piaget denominou "processo de equilibração majorante", sobre o qual também Matui (1995, p. 51-52) explica:

A origem dos conhecimentos, ou a Psicogênese, se dá sempre
relacionando a "matéria" do objeto com a "forma" do sujeito. Conhecer
é dar forma a uma matéria pela interação. Parte do conhecimento vem
do objeto, isto é, da experiência, e parte vem do sujeito, da sua
invenção reflexiva. A ampliação dos conhecimentos sobre os objetos
pode ser assim descrita: o aluno, levando em conta seu nível de
desenvolvimento e suas estruturas de conhecimento tem ideias
prévias ou hipóteses conceituais a respeito da "matéria" do objeto de
conhecimento. Interagindo com a matéria, passa a assimilá-la de
acordo com essas ideias ou hipóteses. Entretanto, a matéria, como
tem seu próprio conteúdo, oferece resistência ao aluno, isto é, pode
não ser assimilável conforme as ideias ou hipóteses que o aluno
formulou. Consequentemente, ele precisa alterar suas ideias,
provocando mudanças. Também é possível que aconteça outro
processo: a matéria pode ser assimilada pela "forma de ideia"
(hipótese) que o sujeito faz, porque já era hipótese avançada (Piaget
chama de esquema antecipador), mas exige mudanças posteriores na
estrutura cognitiva do sujeito, através da acomodação. (MATUl, 1995,
p. $51-52$ )

Durante a interação, na tarefa do sujeito de dar forma ao objeto, Piaget construiu duas noções relevantes sobre conceitos de conhecimento empírico e conhecimento reflexivo. Enquanto o primeiro se refere às informações que o sujeito retira do objeto, o segundo remete à reflexão sobre a maneira de o sujeito se relacionar com esse objeto, nas ações que faz sobre esse este (como relacionar, comparar, ordenar e classificar).

Outra noção fundamental da teoria piagetiana diz respeito à ideia de estágios, que designam etapas do desenvolvimento da inteligência. Nesse percurso, o avanço cognitivo ocorre por saltos e rupturas em que a lógica de um momento do pensamento é sempre superada pela posterior. Assim, as aquisições cognitivas não são isoladas, justamente porque formam estruturas de conjunto, integrativas, que não substituem umas às outras.

Como os esquemas de assimilação originam-se na ação, esta aparece como a origem de todo conhecimento. [...] O termo ação não se refere unicamente à "ação material" (aberta ou manifesta). Da mesma 
maneira, o termo "objeto" não se refere unicamente a objeto material (a linguagem é tão "objeto a conhecer" quanto os objetos físicos que rodeiam um lactante). Conforme o tipo de objeto com que interage e conforme o nível de desenvolvimento do sujeito, o termo ação pode remeter a interações sociais ou a ações internalizadas, assim como as ações materiais individuais. No entanto, o que importa assinalar é que a ação envolve uma transformação do objeto (às vezes, uma transformação física; porém, mais importante ainda, uma transformação conceitual) e uma transformação do sujeito (às vezes, uma ampliação do domínio de aplicação de seus esquemas; às vezes, uma modificação de seus esquemas cognitivos). Portanto, as modificações nos esquemas cognitivos não são o resultado de uma "tendência à mudança" ou de uma maturação endógena, mas o resultado da interação com o mundo. É o não-assimilável que apresenta desafios cognitivos. [...] O progresso cognitivo é, pois, construtivo no sentido forte do termo: há organizações parciais que abrigam, em certos momentos, a reestruturações totais (uma reorganização completa dos esquemas cognitivos). Essas novas estruturas são relativamente estáveis, dentro de certos domínios e por certo tempo, até que novas crises cognitivas obriguem a uma nova reestruturação. Esses modos de organização relativamente estáveis são o que caracteriza precisamente os grandes estágios do desenvolvimento cognitivo. (FERREIRO, 2001a, p. 93-94, grifos do autor)

Piaget, ao definir o desenvolvimento como um processo que se realiza por equilibrações sucessivas, observou que o sujeito elabora estruturas mentais que, embora sejam construídas em continuidade, são caracterizadas por etapas, as quais delineiam momentos específicos da evolução cognitiva. Esses estágios de desenvolvimento são, simultaneamente, contínuos (porque se apoiam sempre no anterior, incorporando-o e transformando-o) e descontínuos (porque há transformações qualitativas radicais no modo de pensar das crianças). Por estarem, assim, relacionadas no âmbito de um mesmo processo, ocorre uma construção sucessiva de novos esquemas que se diferenciam dos anteriores por serem cada vez mais elaborados e flexíveis.

Segundo Davis e Oliveira (2010), a despeito das fases de pensamento identificadas por Piaget, é importante destacar que as faixas etárias previstas por ele se referem apenas à média das idades em que determinadas formas de pensamento prevalecem, e não devem ser observadas como rigidamente demarcadas. Com base no que foi visto, é preciso reconhecer que, fortemente marcado pela ideia de maturação, Piaget acreditava que as crianças apresentam um modelo universal de desenvolvimento, apresentando características psicológicas específicas em determinadas faixas etárias. 
Considerava, no entanto, que, nas formas de pensar, pode haver avanços ou retrocessos de acordo com a natureza do ambiente em que as crianças vivem, pressupondo que os contextos mais desafiadores são potencialmente estimulantes para o desenvolvimento cognitivo. Apesar disso, sob esta concepção, não se pode "pular" etapas, pois a sequência de desenvolvimento é sempre invariável.

Para a passagem de uma etapa à outra, Piaget (1999) julgava determinantes quatro fatores, quais sejam: a maturidade do sistema nervoso; a interação social; a experiência física com os objetos; e o processo de equilibração majorante.

Como se pode constatar a partir das considerações anteriores, as relações entre as concepções teóricas do construtivismo estão sustentadas pelos estudos que têm como foco a concepção ativa do sujeito aprendiz e a consequente construção endógena do pensamento.

A criança, com o desenvolvimento da inteligência, vai se tornando cada vez mais autônoma, com base em uma construção que ninguém pode fazer pelo outro, ao mesmo tempo em que se legitima o lugar do outro como aquele com quem contamos para fazer avanços.

A progressão dos processos cognitivos está relacionada com 0 desenvolvimento. Para se compreender essa relação, é importante considerar a influência das concepções que subsidiam um e outro aspecto, uma vez que estas estão presentes em todas as teorias do comportamento e do pensamento humanos. Além disso, abarcam conceitos fundamentais que condicionam posturas teóricas, e, a partir destas, práticas pedagógicas.

Palangana (2015) esclarece que Piaget, mais preocupado em estudar o processo de desenvolvimento, abordou o tema da aprendizagem a fim de explicar os mecanismos de construção do conhecimento.

Piaget (1999) entendia o desenvolvimento humano vinculado diretamente ao processo de maturação, enquanto a aprendizagem estaria relacionada aos conteúdos adquiridos pela experiência, ou àqueles que, não decorrentes da experiência, são construídos pelas estruturas operatórias do pensamento; no entanto, de modo geral, quando se referia à aprendizagem, estava se reportando ao processo de desenvolvimento, uma vez que estaria subjugada a este e obedeceria às mesmas leis. Nas palavras de Becker (2012): 
se age, e não porque se ensina, por mais que o ensino possa colaborar com essa atividade. (BECKER, 2012, p. 32)

E como os princípios postulados se concretizam na educação? Na tentativa de compreender as implicações do construtivismo psicogenético para a educação, recorremos a Becker (2012), que explica que, como a inteligência se desenvolve pela reorganização de estruturas mentais, a aprendizagem depende da interação com o objeto a conhecer para dele "retirar" informações.

A fim de que possa avançar no processo de conhecer, esse mesmo aluno precisará "trabalhar" com as informações assimiladas, o que se dá por meio da ação reflexiva ou operatória, pela qual poderá estabelecer relações de causalidade, elaboração e reelaboração de hipóteses, fazer classificações e seriações, bem como fazer generalizações.

Para tanto, o professor precisará pautar as proposições didáticas no nível de desenvolvimento do aluno, nos conhecimentos prévios que este já construiu e nas relações de logicidade que vai estabelecendo entre eles. Do mesmo modo, não poderá desconsiderar a importância do conflito cognitivo como uma condição essencial para que o aprendiz modifique seus esquemas de pensamento. Isso porque

as contradições [...] são as próprias condições para a aprendizagem, pois colocam o aprendiz em situação de conflito cognitivo: um conflito que vai gerar necessidade de superação de hipóteses inadequadas através da construção de novas teorias explicativas. (WEISZ; SANCHEZ, 2002, p. 25)

Em razão dessas diretrizes, é importante que o professor pense seu planejamento e ação pedagógica ocupando-se não somente do como ensinar (no sentido de buscar métodos e técnicas para isso), mas considerando também - e principalmente - o modo como o aluno aprende.

Se o professor não sabe o que o aluno pensa a respeito do conteúdo que quer que ele aprenda, o ensino que oferece não tem com quem dialogar. Restará a ele atuar como numa brincadeira de cobra-cega, tateando e fazendo sua parte, na esperança de que o outro faça a parte dele: aprenda. (WEISZ; SANCHEZ, 2002, p. 42)

Essa consideração pressupõe que, na visão construtivista, deve-se proceder à uma avaliação formativa, que atribui um valor relacional a tudo o que é favorável à aprendizagem. 
O ensino deve, portanto, ser repensado em função da ação do sujeito, que é a principal fonte de aprendizagem. Becker (2012, p. 38) acrescenta que "é preciso compreender o processo de construção de conhecimento como condição prévia, em cada patamar, de qualquer aprendizagem. [...] O conteúdo deve ser entendido como meio, e não como objetivo."

Assim, ao se definir o construtivismo, é preciso ter em mente, de um lado, que o conhecimento não é algo pronto e acabado, e, de outro, que este se constitui pela interação do sujeito com o meio físico e social, não podendo ser "doado" (como afirmam os empiristas), tampouco é fruto do desenvolvimento espontâneo do indivíduo (como postulam os inatistas). Logo, é fundamental salientar que, apesar das contribuições substanciais que o construtivismo psicogenético piagetiano deixou como legado para a educação, este não pode ser confundido com um método de ensino ou uma proposta didático-pedagógica, uma vez que consiste em um aporte conceitual, uma concepção teórica sobre a gênese do conhecimento e do pensamento. Um contributo que nos faz pensar também na necessidade de propor mudanças conceituais em diferentes instâncias, o que exige rever 0 projeto pedagógico, a organização curricular, a metodologia e o processo de avaliação e de formação dos professores em serviço.

Tão fundamental quanto o construtivismo psicogenético de Piaget, a abordagem histórico-cultural tem influenciado sobremaneira os princípios norteadores da educação.

\section{b) A abordagem histórico-cultural}

A abordagem histórico-cultural foi liderada pelos estudos de Vigotski. Ele nasceu na Rússia, em 1896, e faleceu em 1934; apesar da vida breve, produziu vasta e relevante obra, que atualmente ainda contribui de modo significativo tanto para a Psicologia, quanto para a Educação.

Sua obra - assim como a de Piaget - desenvolveu-se mais ou menos na mesma época, o que os levou a se depararem com um cenário semelhante, uma vez que, na Psicologia, duas correntes epistemológicas opostas ganhavam espaço: por um lado, os teóricos que acreditavam que o conhecimento humano é inato, e, por outro, os estudiosos para quem o conhecimento advinha dos estímulos do ambiente.

Vigotski, entendendo que a maturação, por si só, não seria suficiente para explicar a aquisição de comportamentos especificamente humanos, atribuiu o fato de 
algumas teorias elegerem a maturação como principal condicionante do desenvolvimento à convergência feita por muitos estudos entre a psicologia animal e a psicologia da criança: muitos estudiosos não percebiam a singularidade das formas de comportamento humano, considerando-as extensão do comportamento animal (PALANGANA, 2015)

Nesse contexto, por compreender a necessidade de estabelecer referenciais teóricos que unificassem as concepções a respeito dos processos psicológicos humanos, Vigotski enveredou na formulação de um novo modelo teórico, mais abrangente, e o fez assumindo uma postura genética (no sentido de buscar a gênese), em que se ocupou de investigar o desenvolvimento das capacidades intelectuais humanas, em especial, as funções psicológicas superiores ${ }^{9}$.

Considerando o mundo um universo em constante transformação, em que o homem se constrói pelas relações com outros sujeitos, com o meio e com a cultura, a vertente histórico-cultural, fundamentada na Psicologia estudada por Vigotski e por seus colaboradores, vem contribuir para o contexto educacional, trazendo para esse campo o modo dialético de pensar.

Com seus postulados, Vigotski ampliou os horizontes da área, sendo "pioneiro na descrição dos mecanismos pelos quais a cultura incorpora-se na natureza de cada pessoa, enfatizando as origens sociais da linguagem e do pensamento." (PALANGANA, 2015, p. 96).

Vigotski assumiu como pressupostos filosóficos e epistemológicos o pensamento de Karl Marx e Friedrich Engels, desenvolvendo um método analíticoexperimental subsidiado pela abordagem dialético-materialista.

Partindo dos princípios do materialismo histórico dialético e entendendo que as funções psicológicas superiores são aquelas que interessam à psicologia humana, Vigotski e seus continuadores dedicaram-se ao estudo de diversas temáticas: a relação entre cérebro e psiquismo; a relação entre desenvolvimento e aprendizagem e o conceito de zona de desenvolvimento próximo; a relação entre pensamento e linguagem; a consciência e as emoções; o conceito de atividade, que, presente na Psicologia soviética desde seu início, será melhor sistematizado por Leontiev. Todas essas questões estão interrelacionadas, e são fundamentais aos educadores e psicólogos

\footnotetext{
${ }^{9}$ Segundo Oliveira (1997, p. 23), as funções psicológicas superiores caracterizam o funcionamento mental tipicamente humano e consistem nas ações voluntárias, intencionais e conscientemente controladas, como a atenção voluntária, a memorização ativa, o pensamento abstrato e o comportamento intencional. Estas se diferenciam de mecanismos mais elementares, como os reflexos, as reações automáticas e as associações simples.
} 
envolvidos com as questões educacionais. (BERNARDES; ASBAHR, 2007, p. 317)

A esse respeito, esclarece Palangana (2015, p. 99) que Vigotski, considerando o homem um sujeito historicamente situado, isto é, pertencente a um contexto sociocultural específico, entendia que

as mudanças históricas na sociedade, na vida material, produzem modificações na "natureza humana", ou seja, na consciência e no comportamento dos homens. Embora essa proposta já tivesse sido estudada por outros teóricos da psicologia, Vigotski foi o primeiro a adotá-la como parâmetro para analisar o desenvolvimento das funções psicológicas superiores. (PALANGANA, 2015, p. 99)

Suas pesquisas tinham como foco central explicar de que maneira a maturação e a aprendizagem interagem com o meio, social e historicamente determinado, de modo a produzir as funções complexas do pensamento.

Partindo do princípio de que as condições sociais e a base biológica estão em interação constante, observou que as funções mentais complexas se formam a partir das estruturas orgânicas elementares, estas sim determinadas pela maturação, e se desenvolvem dependendo da natureza das experiências sociais às quais as crianças são expostas. Logo, os fatores biológicos prevalecem sobre os sociais somente no início da vida, uma vez que o pensamento e o comportamento passam a ser orientados pelas interações que essa criança estabelece com pessoas mais experientes. Sob essa perspectiva, a linguagem é o fator determinante, potente recurso de mediação entre a criança e o mundo.

Vigotski (2008, p. 59-60) explica que a construção do pensamento humano ocorre graças ao emprego de instrumentos (de modo correlato ao arado, nas plantações) e de signos criados pela história em um contexto social determinado.

A invenção do uso de signos como meios auxiliares para solucionar um dado problema psicológico (lembrar, comparar, relatar, escolher etc.) é análoga à invenção e uso de instrumentos, só que agora no campo psicológico. O signo age como um instrumento da atividade psicológica de maneira análoga ao papel de um instrumento no trabalho. (VIGOTSKI, 2008, p. 59-60)

Os instrumentos diferenciam-se dos signos pela forma como influenciam e orientam o comportamento, uma vez que os primeiros constituem o meio pelo qual a atividade humana controla externamente a natureza; os signos, por sua vez, não 
modificam os objetos, pelo contrário, modificam o homem internamente, pois emprestam significações às suas ações em tarefas realizadas conjuntamente.

Assim, segundo Oliveira (1997), estes podem ser definidos como os elementos que expressam ou representam outros objetos, sendo interpretáveis como representação da realidade. Vem daí a importância dos recursos mediadores. Por mediação, entende-se o ato de interpor algo entre uma coisa e outra: "mediação, em termos genéricos, é o processo de intervenção de um elemento intermediativo numa relação: a relação deixa, então, de ser direta e passa a ser mediada por esse elemento." (OLIVEIRA, 1997, p. 26)

Deste modo, instrumentos e signos medeiam a relação do homem com 0 entorno, interpondo o EU e o MUNDO. Enquanto os instrumentos físicos transformam o ambiente em um momento específico, os signos constituem uma representação simbólica e são introjetados na mente pela relação do sujeito com o meio, pois criam representações de natureza semiótica que substituem os objetos do real, designando objetos, seres e situações, permitindo à mente abstrair e transitar, inclusive, por representações no tempo e no espaço, pensar nos objetos quando ausentes, imaginar e fazer planos.

Em um movimento de internalização, os signos e as marcas externas produzidas socialmente vão se transformando em processos que se organizam internamente, formando estruturas complexas e articuladas chamadas de sistemas simbólicos.

Pela linguagem, principal instrumento de representação simbólica, o homem se comunica, compartilha vivências com o meio e desenvolve uma compreensão generalizada do mundo. Palangana (2015) explica que, quando os adultos nomeiam objetos, estabelecendo associações para a criança, estão ajudando-a a construir formas mais complexas e sofisticadas de se relacionar com a realidade. Isso porque a aquisição de um sistema linguístico organiza os processos mentais da criança, dando forma ao seu pensamento, pois, além de nomear um objeto, a palavra também Ihe permite especificar as suas principais características, generalizando-as para, posteriormente, relacioná-las em categorias. Esse processo é conhecido como "pensamento generalizante".

Assim, é por meio dos instrumentos simbólicos (a cultura, os valores, as crenças, os costumes, as tradições e os conhecimentos elaborados por gerações anteriores) que o grupo social fornece ao indivíduo formas de perceber e organizar o 
real, de modo a constituir os recursos psicológicos que medeiam sua relação com o mundo. Antes de controlar o próprio comportamento, a criança começa a controlar o ambiente por meio da ajuda da fala, o que lhe permite construir relação com o ambiente, ao mesmo tempo em que organiza o próprio comportamento.

\begin{abstract}
Nessas circunstâncias, parece que é natural e necessário para a criança falar enquanto age. No nosso laboratório observamos que a fala não só acompanha a atividade prática, como também tem um papel específico na sua realização. [...] Essas observações levam-me a concluir que as crianças resolvem suas tarefas práticas com a ajuda da fala, assim como dos olhos e das mãos. Essa unidade de percepção, fala e ação que, em última instância, provoca a internalização do campo visual, constitui o objeto central de qualquer análise da origem das formas caracteristicamente humanas de comportamento. (VIGOTSKI, 2007, p. 13)
\end{abstract}

Pode-se afirmar, então, que a dimensão sociocultural é importante não apenas como mero contexto em que o homem está inserido, mas, também, porque funciona como um organizador do mundo em que vive esse homem, uma vez que lhe fornece muitos elementos carregados de significado.

A forma como a fala é utilizada na interação social com adultos e
colegas mais velhos desempenha um papel importante na formação e
organização do pensamento complexo e abstrato individual. O
pensamento infantil, amplamente guiado pela fala e pelo
comportamento dos mais experientes, gradativamente adquire a
capacidade de se autorregular. [...] Esta interiorização progressiva das
orientações advindas do meio social não se faz, entretanto, de forma
linear. Caso isso ocorresse, não se poderia pressupor, como Vigotski
de fato o faz, que a criança seja um ser ativo. Adicionalmente, sua
teoria seria marcada por um forte determinismo do social no individual,
uma vez que este último simplesmente espelharia o primeiro. [...]
Assim, as funções mentais superiores - como a capacidade de
solucionar problemas, o armazenamento e uso adequado da memória,
a formação de novos conceitos, o desenvolvimento da vontade -
aparecem, inicialmente, no plano social (ou seja, na interação
envolvendo pessoas) e depois elas surgem no plano psicológico (ou
seja, no próprio indivíduo). A construção do real pela criança, a
apropriação que esta faz da experiência social, parte, pois, do social
(da interação com os outros) e, paulatinamente, é internalizada por
ela. (DAVIS; OLIVEIRA, 2010, p. 56-57)

Essa explicação é fundamental, haja vista que o trabalho de Vigotski pressupõe que o processo de desenvolvimento humano ocorre dialeticamente de fora para dentro e de dentro para fora, com base no aparato humano e na internalização de significados fornecidos pela cultura. O processo de internalização, contudo, pressupõe um 
mecanismo ativo, pelo qual a criança, ao mesmo tempo em que se integra ao social, posiciona-se frente a ele, transformando-o pela própria conduta.

A esse respeito, Oliveira (1997) complementa que, para Vigotski, a cultura não é algo pronto, um sistema estático ao qual cada pessoa se submete, mas, sim, um "palco de negociações" em que estão todos, em um constante movimento de recriação e reinterpretações de informações, conceitos e significados.

A fim de esclarecer esse movimento, Vigotski (2007, p. 57- 58) afirma que toda função psicológica se forma primeiramente em situações interpessoais, para, posteriormente, constituir-se em intrapessoal.

Uma operação que inicialmente representa uma atividade externa é reconstruída e começa a ocorrer internamente. [...] todas as funções no desenvolvimento da criança aparecem duas vezes: primeiro, no nível social, e depois no nível individual; primeiro, entre pessoas (interpsicológica) e depois, no interior da criança (intrapsicológica). Isso se aplica igualmente para a atenção voluntária, para a memória lógica e para a formação de conceitos. Todas as funções superiores originam-se das relações reais entre indivíduos humanos. (VIGOTSKI, 2007, p. 57- 58)

Com essas ideias, Vigotski postulou a aprendizagem como um processo ativo intermediado pela relação do sujeito com o meio e com os outros.

Estreitamente vinculado ao processo de internalização, situa-se a relação entre desenvolvimento e aprendizagem.

Palangana (2015) assinala que, tal como Piaget, Vigotski explicou essa relação pautado em pressupostos interacionistas, mas, que, se por um lado, o primeiro valorizou o desenvolvimento como mola da aprendizagem, o segundo apontou a aprendizagem como propulsora para o desenvolvimento.

Ao questionar as concepções circulantes na época, Vigotski criticou o posicionamento de Piaget (o desenvolvimento antecede a aprendizagem) e o dos behavioristas (que ambos os processos são coincidentes, ocorrendo simultaneamente) e propôs uma terceira posição teórica.

Segundo Vigotski, aprendizagem e desenvolvimento são processos distintos e interdependentes, pois um torna o outro possível. No entanto, é a aprendizagem que mobiliza o desenvolvimento. Este se amplia com o princípio de Zona de Desenvolvimento Proximal, uma vez que pressupõe como a criança, quando tem que lidar com funções em vias de amadurecimento, pode resolver problemas com a ajuda de outros e dar saltos qualitativos no desenvolvimento cognitivo. 
Essa hipótese adquire fundamental importância na medida em que põe em questão as teorias - sobre a relação entre desenvolvimento e aprendizagem - que defendem o tradicional princípio da aplicação de uma orientação pedagógica desejável, uma vez diagnosticado o desenvolvimento. Não é difícil perceber que essas posturas pedagógicas trazem implícita a ideia de que o ensino deve prosseguir com base no desenvolvimento efetivo, já produzido. Contrapondo-se a essa visão (caracteristicamente piagetiana), Vigotski acreditava que a aprendizagem cria uma zona de desenvolvimento proximal, ou seja, ela ativa processos de desenvolvimento que se tornam funcionais na medida em que a criança interage com pessoas em seu ambiente, internalizando valores, significados, regras, enfim, o conhecimento disponível em seu contexto social. [...] Vigotski defendeu a tese de que a aprendizagem antecede o desenvolvimento. (PALANGANA, 2015, p. 136)

A Zona de Desenvolvimento Proximal (ZDP) evidencia-se pelo avanço que alguém, por meio da ajuda de outro mais experiente, pode fazer a partir de sua Zona de Desenvolvimento Real.

O "outro social" é fundamental nesse processo, uma vez que, por intermédio de sua intervenção, o avanço se consolida e vem situar-se, posteriormente, na Zona de Desenvolvimento Real do indivíduo. Nas palavras de Vigotski (2007, p. 98-99):

A zona de desenvolvimento real seria o nível de desenvolvimento real de uma criança [e] define funções já amadurecidas, ou seja, os produtos finais do desenvolvimento. Se uma criança pode fazer tal e tal coisa independentemente, isso significa que as funções para tal e tal coisa já amadureceram nela. A zona de desenvolvimento proximal define aquelas funções que ainda não amadureceram, mas que estão em processo de maturação, funções que não amadureceram, mas que estão presentes em estado embrionário. [...] $O$ nível de desenvolvimento real caracteriza 0 desenvolvimento mental retrospectivamente, enquanto a zona de desenvolvimento proximal caracteriza o desenvolvimento prospectivamente. (VIGOTSKI, 2007, p. 98-99)

Tais postulados nos levam a indagar: como esses princípios se traduzem na prática pedagógica?

Ao elucidar a contribuição do trabalho de Vigotski para a educação, Oliveira (2006) aponta a importância de se ter em mente que a teoria pode iluminar a prática, mas, ainda assim, não the fornecer instrumentos metodológicos que possam ser "aplicados" diretamente. Deste modo, cabe-nos buscar, na teoria vigotskiana, elementos que subsidiem a reflexão no que diz respeito à educação.

Iniciando pela relação entre os processos de aprendizagem e desenvolvimento, vale considerar, então, que, se o aprendizado promove avanços no desenvolvimento, 
é preciso compreender que o ensino não se dirige ao conhecimento já estabilizado, devendo pautar-se nas possibilidades de ação e de representação não incorporadas pelos alunos.

A educação deve ser, portanto, prospectiva. Isso significa que é preciso olhar para além de "até onde a criança já chegou" e, ao considerar que ela está em constante transformação, identificar conhecimentos embrionários, a fim de atuar em Zonas de Desenvolvimento Proximal.

O professor tem o papel explícito de interferir na ZDP dos alunos, provocando avanços que não ocorreriam espontaneamente. O único bom ensino é aquele que se adianta ao desenvolvimento. Os procedimentos regulares que ocorrem na escola - demonstração, assistência, fornecimento de pistas, instruções - são fundamentais na promoção do "bom ensino". Isto é, a criança não tem condições de percorrer sozinha o caminho do aprendizado. A intervenção de outras pessoas - que no caso específico da escola são o professor e as demais crianças - é fundamental para a promoção do desenvolvimento do indivíduo. (OLIVEIRA, 1997, p. 62).

Considerando esse pressuposto, Vigotski ampliou a reflexão sobre o papel do professor junto ao aluno. Não se tratando de deixar o aluno "desabrochar", nem de impor-Ihe passivamente o meio para que ele o absorva, suas considerações apontam para um importante avanço qualitativo no que refere às relações existentes entre a linguagem, o desenvolvimento, a aprendizagem, o papel da intervenção docente e a interação entre os indivíduos.

Abordar tais fundamentos realça, igualmente, a importância dos processos interacionais em sala de aula a partir do contexto sociocultural do grupo, de modo que cabe ao professor oportunizar situações planejadas para favorecer interações, com o propósito de intervir na Zona de Desenvolvimento Proximal dos alunos.

Esse princípio leva a outro: a vital importância da intervenção docente no processo de aprendizagem. Daí a valorização de uma ação intencional, organizada, deliberada e explícita do professor, promovendo intervenções potentes para que o aluno avance.

Embora processos de aprendizagem ocorram constantemente na relação do indivíduo com o meio, quando existe a intervenção deliberada de um outro social nesse processo, ensino e aprendizagem passam a fazer parte de um todo único, indissociável, envolvendo quem ensina, quem aprende e a relação entre essas pessoas. (OLIVEIRA, 2006, p. 58) 
Daí vem também a importância atribuída à escola como

agência social explicitamente encarregada de transmitir sistemas organizados de conhecimento e modos de funcionamento intelectual às crianças e jovens, tem um papel essencial na promoção do desenvolvimento psicológico dos indivíduos que vivem nas sociedades letradas. (OLIVEIRA, 2006, p. 61)

\subsection{Piaget e Vigotski: convergências e divergências}

Ponderar as relações entre o construtivismo psicogenético e a abordagem histórico-cultural nos faz refletir sobre o pensamento que se fundamenta na divisão "isto ou aquilo", de modo que as diferentes concepções parecem não admitir integração, complementação e interação.

Ao contrário do que se possa pensar, na prática pedagógica, o construtivismo psicogenético e a abordagem histórico-cultural não necessariamente se contrapõem, justamente porque se constituem como diferentes olhares que podem se integrar na compreensão da complexidade do "fazer" em sala de aula. De fato, na pluralidade de ações e intervenções, de conquistas cognitivas e prioridades do ensino, de mediações e interações que ocorrem em uma classe, é difícil recuperar os limites que separam essas duas posturas teóricas. Logo, não se trata de optar por uma ou outra visão, mas de analisar as contribuições de cada uma para a educação, buscando pontos de contribuição e de apoio em cada uma delas. O termo construtivismo representa esse esforço na construção da prática pedagógica.

Segundo vários autores (CASTORINA et al., 2006; COLL, 2004; FREITAS, 2002; OLIVEIRA, 1997), embora Piaget considerasse a relevância da interação no processo de construção de conhecimentos, vale ressaltar que ele não se dedicou a investigar com profundidade a questão da interação; por sua vez, Vigotski, imerso nas questões políticas e sociais de sua época, partiu de outro ponto de investigação. Essa constatação nos ajuda a compreender porque ambos não convergem plenamente nesse ponto, sendo imprescindível observar o aporte conceitual de cada um como decorrente de focos distintos de investigação: enquanto para Piaget, o desenvolvimento precede a aprendizagem, Vigotski postula que a aprendizagem desperta o desenvolvimento.

A divergência entre ambos se situa nesse princípio, justificando diferentes recortes de investigação e de posicionamento psicopedagógico. De qualquer forma, 
vale registrar a convergência existente entre eles na defesa do interacionismo em oposição aos modelos empirista e inatista que prevaleciam na época.

Pelo que foi exposto até aqui, reconhecemos a necessidade de coordenar as semelhanças e as diferenças entre a epistemologia genética e os postulados históricoculturais se tivermos a pretensão de superar a dicotomia que não ajuda a repensar a prática docente, e tampouco as interações em sala de aula.

Ao longo deste capítulo, procuramos abordar as diferentes concepções de aprendizagem, situando-as entre as distintas concepções filosóficas sobre o mundo, o homem e o modo como este constrói conhecimento.

$\mathrm{Na}$ intenção de sintetizar os principais fundamentos postulados até aqui, recorremos a Colello (2010), em razão de sua contribuição para a compreensão do tema.

Quadro 5 - Concepções de homem, mundo e conhecimento

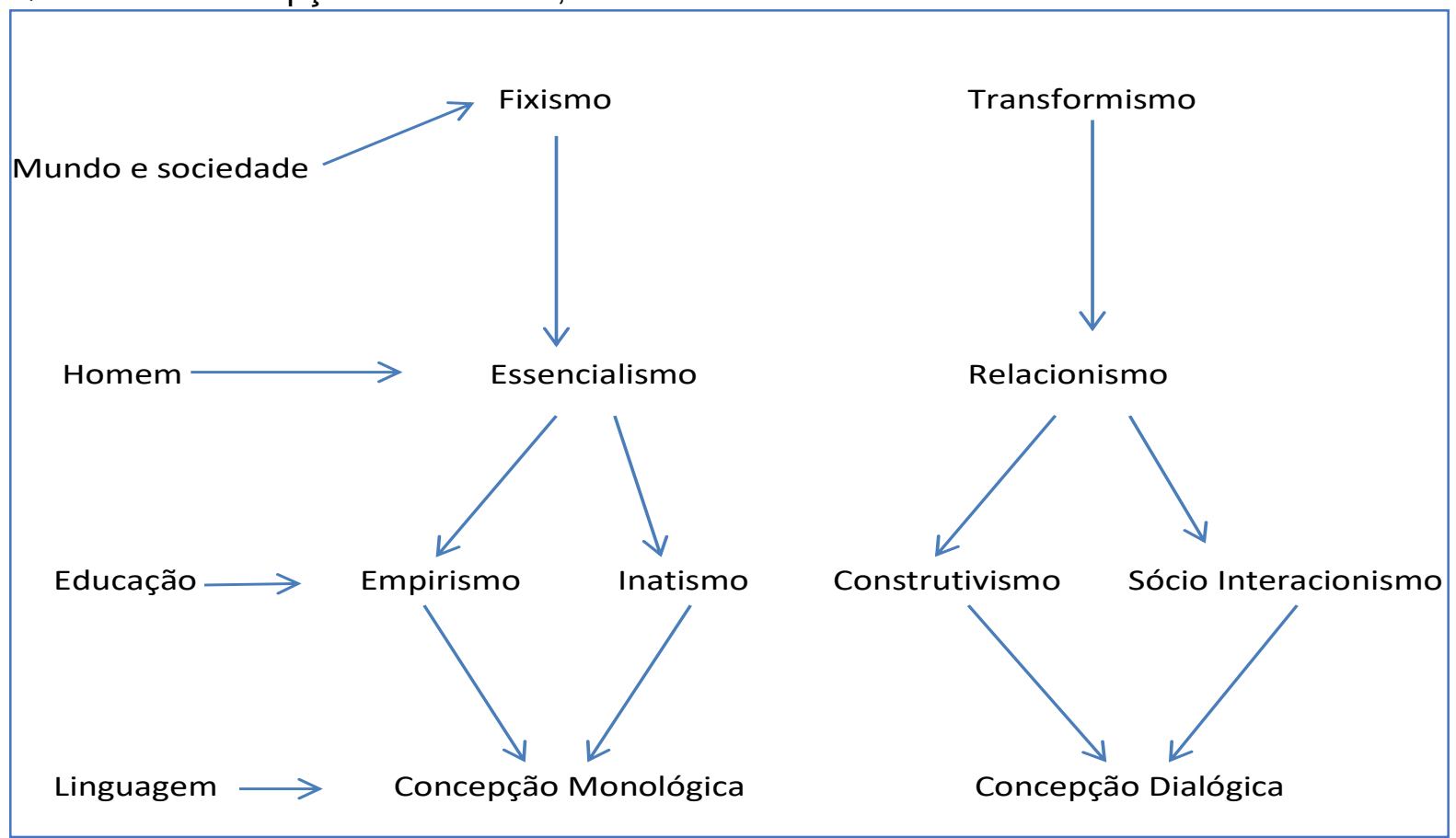

Fonte: COLELLO $(2011,2012)^{10}$

Ao pensarmos como as obras de Piaget e de Vigotski contribuem para o ensino, e, particularmente, auxiliam-nos a ampliar considerações no âmbito das concepções sobre o ensino da língua, no próximo capítulo nos dedicaremos, com especial atenção, a essa análise.

${ }^{10}$ Este quadro faz parte da aula Modelos de Ensino: das concepções docentes às práticas pedagógicas, ministrada pela Prof. ${ }^{a}$ Dr. ${ }^{a}$ Silvia Mattos Gasparian Colello, nos cursos "Ética, valores e saúde e "Ética, valores e cidadania, da UNIVESP - Universidade Virtual do Estado de São Paulo, em 2011 e 2012, respectivamente. 


\section{A LÍNGUA ESCRITA COMO OBJETO DE INVESTIGAÇÃO E ENSINO}

Pressupondo que a prática docente se ancora em representações de homem, mundo e conhecimento, este capítulo pretende investigar as concepções correntes sobre a língua escrita e seu ensino, averiguando de que modo se articulam e como incidem sobre a aprendizagem discente.

\subsection{Concepções de língua e formação docente}

No plano acadêmico e científico, muito se tem avançado sobre as conceitualizações a respeito da língua, bem como em relação às diretrizes pedagógicas capazes de orientar o processo educativo. Contudo, apesar de tais avanços e, ainda que revelem a intenção de fazer bem aquilo a que se propõe, a escola não tem sido eficiente no ensino da língua escrita. $O$ acompanhamento do aproveitamento escolar, tanto pelos órgãos oficiais, quanto pelas iniciativas da sociedade civil, revela um grande número de crianças e adolescentes que, mesmo tendo frequentado regularmente as aulas, concluem o Ensino Fundamental alfabetizando-se tardiamente ou fazendo-o em condições de alfabetismo insuficiente.

Tais índices reforçam a necessidade de se investir em uma escola que, além de atender quantitativamente à população, disponibilize a todos um ensino de melhor qualidade, assumindo o objetivo de pleno domínio da escrita desde os primeiros anos de escolaridade.

Nesse contexto, a formação dos professores, tanto inicial, quanto em curso do exercício profissional, assume significativa relevância. Ao apontar que os currículos de formação docente têm oscilado entre as esferas metodológica (em que se privilegiam as técnicas e os instrumentos de ação), disciplinar (centrada nos conhecimentos de uma área de saber) e científica (referenciada nas ciências da educação e em outras ciências sociais e humanas, particularmente a Psicologia), Nóvoa (1999, p. 28) destaca a importância de se compreender "os saberes profissionais a partir de um olhar sobre a especificidade da ação concreta dos professores", o que, mais uma vez, justifica a necessidade de se analisar a prática docente.

Em consonância, Formosinho, Kishimoto e Pinazza (2007) ressaltam que os professores constroem seus saberes pedagógicos em um espaço constituído por 
ambiguidades diversas (a práxis pedagógica), lócus de interlocução triangular entre crenças e saberes, saberes e práticas e práticas e crenças. Logo, não basta lançar luz apenas ao fazer dos professores, nem somente aos saberes teóricos aos quais têm acesso, pois os professores tornam-se profissionais reflexivos, capazes de escolhas conscientes, apenas quando articulam, processual e integradamente, seus conhecimentos e práticas às convicções e valores que sustentam a ação docente. Somente assim podem ser conscientes de suas próprias escolhas, uma vez que todo ato educativo é também político, pois, como afirma Ferreiro (1989, p. 31), "nenhuma prática pedagógica é neutra. Todas estão apoiadas em certo modo de conceber o processo de aprendizagem e o objeto dessa aprendizagem".

Na mesma linha de argumentação, Molinari (2010) assevera que a apropriação da cultura é um direito de todos, por ser patrimônio da humanidade. E justamente porque está inserida em um contexto social em que imperam a injustiça e a desigualdade social, cabe à escola rever conteúdos, diretrizes pedagógicas e, ainda, promover situações de ensino e de aprendizagem capazes de fazer com que toda criança possa assumir como próprio o poder de uso da linguagem e da própria língua.

Entendemos, pois, a educação como um compromisso político e um desafio pedagógico, e, portanto, partimos do pressuposto de que, ao planejar e conduzir o processo de alfabetização, os professores põem em jogo suas acepções conceituais. Compreendemos ainda que, mesmo quando essas concepções são frágeis ou nebulosas, elas determinam as escolhas metodológicas, as dinâmicas interativas e os procedimentos didáticos propostos pelos docentes, o que, com efeito, compromete as práticas de ensino.

Partindo dessas considerações, pretendemos, no presente estudo, identificar de que maneira os professores concebem a língua, bem como analisar o modo como suas concepções se articulam com o ensino da escrita na escola.

Para isso, buscamos, neste capítulo, identificar as relações entre as práticas sociais de linguagem e as modalidades de uso da língua. Posteriormente, apontamos para uma breve cronologia das concepções sobre a língua e suas consequências para o ensino da escrita na escola, e o fazemos tomando como referenciais as pesquisas lideradas por Vigotski e por Bakhtin.

Atentamos, também, às mudanças de paradigma que advêm dos estudos de Ferreiro, com a divulgação da Psicogênese da Língua Escrita, o que nos levou à análise das relações entre alfabetização e letramento. 
Concluímos este capítulo assumindo a concepção dialógica da língua como pressuposto de análise e buscamos pontuar brevemente algumas implicações para seu ensino na escola.

\subsection{Linguagem e língua}

Pensar sobre as concepções acerca da língua escrita nos faz buscar respostas a questões específicas, tais como: "o que ensinamos quando ensinamos a ler e a escrever?"; e "como, por que e para que ensinamos a ler e a escrever?".

A fim de responder a essas perguntas, recorremos a Colello (2004), que esclarece que, historicamente, a expressão humana, propriamente dita, teve início no momento em que o homem assumiu a postura ereta, o que lhe possibilitou fazer uso de instrumentos e favoreceu também a comunicação face a face, uma vez que a posição do rosto expandiu seu ângulo de visão e lhe permitiu novas percepções sobre o mundo. Assim, ao fazer uso da palavra, das expressões faciais, dos gestos e das atitudes corporais, o homem foi ampliando suas possibilidades de intercâmbio e comunicação, desenvolvendo a linguagem e criando a cultura.

Nesse contexto, é importante lembrar que, embora a palavra tenha tido fundamental relevância, sempre esteve intrinsicamente vinculada às expressões faciais, aos gestos e às atitudes do falante, que igualmente interferem no sentido da mensagem transmitida. Em todo ato de fala, portanto, gesto e palavra, ambos potentes de significado, representam ideias, que podem ser comunicadas, bem como ser materializadas sob a forma de signos e imagens. A esse respeito, a escrita, a imprensa, o cinema, a fotografia e todo aparato da tecnologia da comunicação foram apenas a continuidade de importantes conquistas no campo das representações, interações e formas de expressão.

Quanto às possibilidades de expressar o pensamento por meio da linguagem, Gutierrez (1978 apud COLELLO, 2004, p. 12) afirma que a linguagem se constrói a partir de cinco dimensões básicas: oral, escrita, kinéstica ${ }^{11}$, icônica ${ }^{12}$ e sonora. A esse conjunto de formas, incluindo suas múltiplas manifestações e interdependências, o autor chamou "linguagem total".

\footnotetext{
${ }^{11}$ Referem-se a esta modalidade de comunicação todas as formas corporais de linguagem, sejam gestos ou movimentos.

12 A linguagem icônica se refere a todas as formas de desenhos e imagens.
} 
Assim, sendo a linguagem oral e a linguagem escrita duas dentre outras formas de manifestação da "linguagem total", é preciso lembrar que, na prática da vida, as formas linguísticas não ocorrem de modo isolado, sendo quase impossível dissociálas.

Embora essa constatação pareça óbvia, não o é se considerarmos o lugar privilegiado que a escrita tem ocupado, particularmente, no âmbito escolar, em detrimento de outras formas de expressão.

Sem desmerecer a importância da escrita e sua contribuição para o desenvolvimento da humanidade, muito menos a relevância de sua aprendizagem, é preciso atentar para o fato de que, para que o indivíduo possa ocupar seu lugar no mundo, exercendo todas as possibilidades de interação, é imprescindível que cada pessoa possa transitar dentre todas as modalidades de comunicação e expressão, apropriando-se de maneiras inteligentes de articular ideias e expressá-las por meio da linguagem em sua totalidade, expandindo suas possibilidades de comunicação, de interação com os outros e de ampliação de conhecimentos.

Considerando, especificamente, as manifestações referentes à linguagem oral e à escrita, Marcuschi (2010) esclarece que

A fala seria uma forma de produção textual-discursiva para fins comunicativos na modalidade oral (situa-se no plano da oralidade, portanto), sem a necessidade de uma tecnologia além do aparato disponível pelo próprio ser humano. Caracteriza-se pelo uso da língua na sua forma de sons sistematicamente articulados e significativos, bem como os aspectos prosódicos, envolvendo ainda, uma série de recursos expressivos de outra ordem, tal como a gestualidade, os movimentos do corpo e a mímica. A escrita seria um modo de produção textual-discursiva para fins comunicativos com certas especificidades materiais e se caracteriza por sua constituição gráfica, embora envolva também recursos de ordem pictórica e outros (situase no plano do letramento). Pode manifestar-se, do ponto de vista de sua tecnologia, por unidades alfabéticas (escrita alfabética), ideogramas (escrita ideográfica) ou unidades iconográficas, sendo que, no geral, não temos uma dessas escritas puras. Trata-se de uma modalidade de uso da língua complementar à fala. (MARCUSCHI, 2010, p. 25-26)

Sobre essas questões, o autor faz considerações relevantes, afirmando que fala e escrita se fundem em um continuum a partir de seu uso, pois escrita e fala não se encontram em polos opostos e dicotômicos; desse modo, "o que determina a variação linguística em todas as suas manifestações são os usos que fazemos da língua. São as formas que se adequam aos usos, e não o contrário" (MARCUSCHI, 
2010, p. 16). Também não há supremacia de uma sobre a outra, haja vista que ambas "são atividades interativas e complementares no contexto das práticas sociais e culturais". (MARCUSCHI, 2010, p. 16)

Evidencia também outros mitos que julga importante combater, tais como: a "escrita é derivada da fala, sendo a fala primária" e "a escrita representa a fala".

No que diz respeito ao fato de que a escrita não representa a fala, vale mencionar que

\begin{abstract}
a escrita não consegue reproduzir muitos dos fenômenos da oralidade, tais como a prosódia, a gestualidade, os movimentos do corpo e dos olhos, entre outros. Em contrapartida, a escrita apresenta elementos significativos próprios, ausentes na fala, tais como o tamanho e tipo de letras, cores e formatos, elementos pictóricos que operam como gestos, mímica e prosódia graficamente representados. Oralidade e escrita são práticas e usos da língua com características próprias, mas não suficientemente opostas para caracterizar dois sistemas linguísticos nem uma dicotomia. (MARCUSCHI, 2010, p. 17)
\end{abstract}

Nesse sentido, destacamos a importância e o significado da alfabetização, uma vez que aprender a ler e a escrever implica reconhecer que, ao homem, cabe o lugar de sujeito, que diz e se diz de diversas maneiras: por meio da fala, pelos movimentos corporais, pelos sons, por meio de signos e pela escrita.

A esse respeito, Colello (2004) aponta que, quando a escola compreende a alfabetização como a aprendizagem de um sistema de comunicação que independe da fala, do desenho, dos gestos e da expressão genuína das ideias, empobrece e limita as possibilidades de uso da "linguagem total", privando o sujeito de viver um amplo espectro de possibilidades expressivas.

O registro gráfico concretizado no ato de escrever é a extensão de outras possibilidades comunicativas (como, por exemplo, falar) que puderam ser adaptadas e organizadas numa nova linguagem. Mas, assim como não existe indício de que a humanidade chegou ao estágio final dessa forma de representação, não há como determinar o momento final da aprendizagem, limitando a alfabetização ao puro conhecimento das letras, na primeira série do Ensino Fundamental. Muito pelo contrário, aquele que escreve deve estar sempre descobrindo novas formas de manifestação e, nesse sentido, a conquista da escrita pressupõe o aproveitamento de todo repertório linguístico (a linguagem total) numa aprendizagem permanente, que nunca se conclui porque traz em si a possibilidade de novas formas de manifestação. A escrita, em qualquer estágio de produção, faz parte de um processo essencialmente criativo. (COLELLO, 2004, p. 14) 
Quanto ao segundo mito, Olson (1998) destaca que atualmente ainda prevalecem arraigadas no ideário docente crenças que definem a escrita alfabética como tecnicamente superior aos demais sistemas de notação, imperando também a noção de que a escrita é a transcrição da fala. Tais concepções justificariam a aprendizagem da leitura e da escrita como um bem indiscutível, algo por si só válido e desejável, independentemente de outras formas de comunicação (COLELLO, 2017).

Em consonância com essa perspectiva, acredita-se ser preciso "consertar" a língua do aluno, especialmente daquele proveniente de classes populares, que é visto como deficiente linguístico. Dessa forma, a norma culta passa a ser o padrão de referência, a "língua certa" e desejável.

"Português", então, deixa de ser a língua que todos os brasileiros falam, com suas múltiplas variedades regionais, sociais e estilísticas, e passa a ser um rótulo usado para designar apenas as regras submetidas ao processo de padronização. Assim o que não está registrado na norma culta, o que não está abrigado nas gramáticas normativas ou nos dicionários, simplesmente não é português. (BAGNO, 2002, p. 160)

Sob essa ótica, de caráter elitista e preconceituoso, a Pedagogia tem pautado o ensino da escrita na escola, privilegiando a norma padrão e o ensino da gramática como modelo idealizado da língua correta a ser aprendida por todos.

Além disso, considerar a escrita como mera transcrição da fala, cuja aprendizagem depende de habilidades de codificação e de decodificação, da simples relação sons e letras, desconsidera que esta é, na verdade, produto histórico da cultura.

Com base nessas observações e tomando a língua como objeto de investigação deste projeto de pesquisa, é preciso identificar que compreensão se tem acerca da escrita, o que nos impõe as seguintes indagações: de que língua estamos falando? De que modo escrita e linguagem se articulam?

A fim de compreendermos essas questões, entendemos ser necessário considerar as diferentes correntes que, historicamente, definiram a linguagem e sua relação com a língua, bem como de que modo seus paradigmas influenciaram o ensino da língua na escola. 


\subsection{A contribuição da linguística e da abordagem histórico-cultural}

Segundo Orlandi (2009), Freitas (2002) e Bortolotto (1998), até os fins do século XIX, duas tendências foram marcos importantes para a constituição do pensamento linguístico.

No século XVII, a primeira delas caracterizou a época das Gramáticas Gerais, momento em que a língua era compreendida pelos filólogos como a expressão do pensamento, uma vez que as operações mentais estariam simbolizadas pela oralidade e escrita.

A linguística, considerada a ciência da expressão, fundamentava o "subjetivismo idealista", isto é, a primazia da língua vinculada ao mundo interno do sujeito. Sob essa ótica, o fenômeno linguístico era entendido como um ato de criação individual, enquanto a língua era apenas um instrumento interno a ser usado por esse sujeito para poder expressar seu pensamento.

Pressupondo que as línguas obedeciam a princípios lógicos e gerais, tal como previsto pelo linguista Noam Chomsky ${ }^{13}$, suas manifestações depreendiam um racionalismo que exigia a precisão dos falantes, e deveriam ser expressas de modo claro e preciso. Isso seria garantido por uma Gramática Geral, modelo que permitiria atingir uma língua ideal, universal, livre de ambiguidades e de equívocos, capaz de assegurar a unidade de comunicação entre os indivíduos.

O século XIX representou outro momento igualmente importante para a compreensão do pensamento linguístico, caracterizando o período da linguística histórica, ou o período das Gramáticas Comparadas. Nesse momento, os ideais de universalidade já não têm mais validade, de modo que o foco dos estudiosos se volta para o fato de que as línguas se transformam com o tempo. Orlandi (2009, p. 13) aponta que

não é mais a precisão, mas a mudança o que importa. É a época dos estudos históricos, em que se procura mostrar que a mudança das línguas não depende da vontade dos homens, mas segue uma necessidade da própria língua, e tem uma regularidade. (ORLANDI, 2009, p. 13)

13 Segundo Reis (2009, p. 112), Chomsky influenciou sobremaneira a linguística teórica ao criar a Gramática Gerativa, assentada no pressuposto de que a linguagem humana se organiza e se sustenta em estruturas cognitivas universais e subjacentes à espécie humana, que tornam possível a aprendizagem de sistemas particulares línguas. Desse modo, aprender uma língua dependeria do estímulo do contexto linguístico e do emprego dessas estruturas. 
Pelo método comparativo, são observadas correspondências gramaticais e sonoras entre as línguas, especialmente as europeias e o sânscrito, as quais passam a ser denominadas como um conjunto: as línguas indo-europeias. A busca pela perfeição deu lugar, então, à procura pela origem linguística, na tentativa de se reconstruir uma língua-mãe.

Ao longo do tempo, essas duas tendências não só sustentaram o pensamento dos estudiosos da linguagem, como também influenciaram as mudanças conceituais que pautaram o desenvolvimento das investigações posteriores sobre a língua. Como já mencionado, são duas linhas distintas:

Uma que se ocupa do percurso psíquico da linguagem, observando a relação entre linguagem e pensamento. Busca o que é único, universal, constante. É chamada de formalismo. A outra é o sociologismo, que se aplica em estudar o percurso social, explorando a relação entre linguagem e sociedade. Procura o que é múltiplo, diverso e variado. Essa divisão, que atravessa a história da linguística, apõe os partidários de que existe uma ordem interna, própria da língua, àqueles que defendem a ideia de que essa ordem reflete a relação da língua com a exterioridade, incluindo suas determinações históricas e sociais. Embora os estudos linguísticos se desenvolvam em várias direções, acabam sendo atravessados e definidos por essas tendências conflitantes: a formalista e a sociologista. (ORLANDI, 2009, p. 17 , grifos do autor)

Bortolotto (1998) reitera que as concepções de fins do século XIX atualmente ainda exercem grande influência no ensino da língua. Assim, quando a escrita é assumida pelo viés do Subjetivismo Idealista, cabe ao leitor apenas "captar" o pensamento do autor, expresso no texto. Como a clareza e a precisão de ideias expressas são os aspectos mais importantes, essa concepção tem como consequência o ensino da gramática tradicional e dos exercícios estruturais, de modo que o autor do texto possa transferir, de forma mais correta e precisa, um pensamento para o papel, ao passo que, ao leitor, cabe compreender a ideia expressa a partir da decifração das sílabas e das palavras.

É o início do século XX, no entanto, que marca o surgimento da linguística como a conhecemos atualmente, isto é, uma ciência autônoma e independente. Tal movimento se deu com Ferdinand de Saussure (1857 - 1913) e a publicação da obra póstuma "Curso de Linguística Geral", em 1916. Nas palavras de Orlandi (2009, p. 21): 
A ciência que ele constituiu tem quatro disciplinas que correspondem a quatro diferentes níveis de análise: a fonologia (estudo das unidades sonoras), a sintaxe (estudo da estrutura das frases), e a morfologia (estudo da forma das palavras) que, juntas, constituem a gramática; e a semântica (estudo dos significados). Com Saussure a linguística ganha um objeto específico: a língua. (ORLANDI, 2009, p. 21):

A posição de Saussure promoveu um deslocamento teórico a partir do qual a língua ganhou status prioritário e a comunicação passou a ser a função essencial da linguagem. Opondo-se à visão anterior, esse pesquisador concebe o "objetivismo abstrato", o qual postula a separação entre língua e fala: considera a primeira como um fato social, um sistema abstrato e geral; e, a segunda, sob uma perspectiva individual, a realização concreta da língua pelo sujeito que fala, o que lhe confere um caráter variável e circunstancial.

A esse respeito, Freitas (2002, p. 133) aponta que, na perspectiva de Saussure, "a língua, tomada como objeto externo, seria objeto da linguística, enquanto a fala, ato individual, não poderia sê-lo", pois, já que a fala depende do indivíduo, não pode constituir foco de estudo científico.

Desse ponto de vista, não são as manifestações individuais relevantes para que alguém consiga compreender e se fazer entender, e, sim, o sistema em que o emissor transmite informações ao receptor por meio da língua entendida como "sistema de signos, disponível para os indivíduos de uma comunidade" (BORTOLOTTO, 1998, p. 4).

Segundo Bortolotto (1998), o signo linguístico seria uma associação entre o significante (imagem acústica - que não corresponde ao som, e sim à imagem mental que fazemos do som) e o significado (seu conceito), ambos unidos apenas por laços convencionais e arbitrários. Sob essa perspectiva,

Não há motivos para que "cão" se chame "cão". Mas é claro, que uma vez que se atribua esse nome, ele passa a ter um valor na língua, e nós o associamos, no nosso cérebro, com a ideia de cão, e não se pode chamar o "cão" de "gato". (ORLANDI, 2009, p. 22).

Saussure compreende também que a língua é um sistema em que cada unidade linguística se define e ganha sentido por meio das relações que estabelece com o todo de que faz parte, ganhando um valor determinado pela identidade que assume no contexto. Assim, o foco prioritário do processo comunicativo é a mensagem, não importando as condições e as características dos falantes. 
Haja vista que seus estudos se baseiam em uma metodologia que utiliza a análise da organização interna da língua, ou seja, sua estrutura, inaugura-se uma corrente de pesquisas sobre a linguagem, conhecida por estruturalismo. Com base nisso, no campo da educação, e, mais especificamente, da alfabetização,

Para que o aluno possa dominar o código, prevalecem nas séries
iniciais, os exercícios de discriminação perceptiva, coordenação
motora e a reprodução passiva, como a cópia de letras sílabas e
palavras. Mais tarde, a atenção se concentra na assimilação de regras
gramaticais, sintáticas e interpretação fechada de textos, sem que o
sujeito possa necessariamente reconhecer nessas tarefas a própria
língua ou a possibilidade de uso nas suas práticas sociais. (COLELLO,
2010, p. 80)

É possível considerar que as diferentes vertentes apresentadas até aqui consistem em uma concepção monológica da língua, uma vez que a concebem como algo pronto, acabado, e que se concretiza apenas unilateralmente, sendo compreendida em sua dimensão formal, estrutural, ou seja, sem a consideração do outro, funcionando como mero instrumento de tradução do pensamento ou um meio de comunicação.

Contrariando as concepções monológicas, outros estudiosos se destacaram por refletirem sobre a linguagem ressaltando seu papel na constituição do sujeito. Desde a perspectiva da Psicologia, um novo paradigma se estabeleceu a partir dos estudos de Vigotski (1896 - 1934), pai da Psicologia histórico-cultural; suas reflexões foram fundamentais para a compreensão de que somos sujeitos determinados na e pela história e cultura, processo que se dá por meio da linguagem.

Segundo Vigotski, ao interiorizar os padrões de comportamento que estabelece com os outros, o indivíduo, mediado pela linguagem, constrói representações e atua no contexto cultural em que está inserido, desenvolvendo a consciência e se tornando sujeito histórico.

Tal concepção nos conduz à constatação de que é pela linguagem que o homem alcança a condição verdadeiramente humana. Pressupondo que a relação do homem com o mundo não é direta, e sim mediada por sistemas simbólicos (os signos), o desenvolvimento das funções psicológicas superiores ocorre pela organização e internalização dos signos linguísticos, já que estes permitem a substituição dos objetos por sua representação e, por essa via, a possibilidade de desenvolver consciência e de operar mentalmente sobre o mundo. 
Os sistemas de representação da realidade - e a linguagem é o sistema simbólico básico de todos os grupos humanos - são, portanto, socialmente dados. É o grupo cultural onde o indivíduo se desenvolve que lhe fornece formas de perceber e organizar o real, as quais vão constituir os instrumentos psicológicos que fazem a mediação entre 0 indivíduo e o mundo. (OLIVEIRA, 1997, p. 36)

Nessa perspectiva, o foco prioritário do processo comunicativo ocorre pela relação que se dá entre os falantes, mediada pela linguagem.

A relação entre o pensamento e a palavra é um processo vivo; o pensamento nasce através das palavras. Uma palavra desprovida de pensamento é uma coisa morta, e um pensamento não expresso por palavras permanece uma sombra. A relação entre eles não é, no entanto, algo já formado e constante; surge ao longo do desenvolvimento e se modifica. (VIGOTSKI, 2008, p.189-190)

Consoante Vigotski (2008), pensamento e linguagem, mesmo com raízes diferentes, sintetizam-se dialeticamente no desenvolvimento. Até dois anos de idade, aproximadamente, os primeiros balbucios ocorrem desarticulados do pensamento, mas, por volta dessa idade, pensamento e linguagem se fundem, dando lugar a uma nova forma de organização linguístico-cognitiva, em que o pensamento se torna verbal e, a linguagem, racional. Desse modo, a fala serve o pensamento e este começa a ser verbalizado, dando lugar à função simbólica da palavra, que ganha significado. Sob essa perspectiva, o pensamento se concretiza por meio das palavras, existindo por seu intermédio.

Assim, a associação entre pensamento e linguagem permite afirmar que

A verdadeira comunicação humana pressupõe uma atitude
generalizante, que constitui um estágio avançado de desenvolvimento
do significado da palavra. As formas mais elevadas de comunicação
humana somente são possíveis porque o pensamento do homem
reflete uma realidade conceitualizada. É por isso que certos
pensamentos não podem ser comunicados às crianças, mesmo que
estejam familiarizadas com as palavras necessárias. Pode ainda estar
faltando o conceito adequadamente generalizado, que por si só,
assegura o pleno entendimento. (VIGOTSKI, 2008, p.8)

A fim de compreender o pensamento verbal, o significado das palavras é aspecto fundamental, porque se configura, simultaneamente, um fenômeno de fala e de pensamento, por ser, cada palavra, uma generalização, um conceito. Ao explicitar essa ideia, Freitas (2002, p. 94) afirma que 
O significado é um fenômeno do pensamento apenas quando o pensamento ganha corpo por meio da fala, e só é fenômeno da fala na medida em que a palavra está ligada ao pensamento, sendo iluminada por ele. Portanto, a união palavra e pensamento é um fenômeno do pensamento verbal e da fala significativa. (FREITAS, 2002, p. 94)

Ainda na contraposição ao monologismo da língua, e buscando entender, particularmente, como o paradigma histórico-cultural se dá na ótica da linguística, destacam-se também Bakhtin (1895-1975) e seu Círculo - grupo constituído por Volóchinov e Medvedev, entre outros intelectuais, que se reuniam regularmente, entre 1919 e 1929, para discutir e debater ideias acerca da filosofia e da linguagem.

Contemporâneo a Vigotski e também nascido na Rússia, Bakhtin igualmente criticou os marcos teóricos da linguística de sua época, combatendo tanto o "subjetivismo idealista" quanto o "objetivismo abstrato". Em relação ao primeiro, considerou equivocado separar vida interior e exterior, uma vez que a enunciação e a língua são frutos da construção social, resultado da interação entre os homens; quanto ao segundo, criticou a suposição de que a língua é objetiva, um sistema abstrato de normas a serem decifradas. Bakhtin (1988) concebe a língua como uma prática viva, que permite a constituição do sujeito pelo desenvolvimento da consciência. Pensar na relação entre a fala e a língua implica considerar que cada enunciação do falante é construída em um contexto linguístico, no qual as palavras são carregadas de sentidos e de valores sociais.

Assim, segundo o linguista russo, nem o "subjetivismo idealista", nem o "objetivismo abstrato" permitem compreender o caráter dialógico da linguagem.

Aqui, chamaremos a atenção ainda para o seguinte fato. $O$ Objetivismo abstrato, ao considerar o sistema da língua como único e essencial para os fenômenos linguísticos, negava o ato discursivo - 0 enunciado - como individual. Nisso, como havíamos dito certa vez, está o próton pseudos do Objetivismo Abstrato. O Subjetivismo individualista considera justamente o ato discursivo - o enunciado como único e essencial. No entanto, ele também define esse ato como individual e por isso tenta explicá-lo a partir das condições da vida psicoindividual do indivíduo falante. Nisso está o seu próton pseudos. De fato, o ato discursivo, ou mais precisamente, o seu produto - 0 enunciado - de modo algum pode ser reconhecido como um fenômeno individual no sentido exato dessa palavra, e tampouco pode ser explicado a partir das condições psicoindividuais e psíquicas ou psicofisiológicas do indivíduo falante. O enunciado é de natureza social. (VOLÓCHINOV, 2017, p. 200, grifos do autor) 
Visando superar essas posturas, Bakhtin (e os demais membros de seu Círculo) propõe uma conceituação em que a construção do enunciado se justifica pela interação e comunicação. Assumindo um pensamento sempre em função de um dado contexto social e histórico, postula uma concepção dialógica da língua ao considerar que todo ato linguístico parte e se volta para o discurso circulante no "simpósio universal".

Nessa direção, Freitas (2009, p. 135) aponta que "todo enunciado é um diálogo, desde a comunicação de viva-voz entre duas pessoas, até as interações mais amplas entre os enunciados. O que importa é a relação ou encontro entre pessoas".

Assim, sob essa ótica, o universo simbólico, carregado de valores, tem papel primordial, pois é por meio dos signos que os sujeitos constroem significados acerca do mundo real e ideológico ${ }^{14}$.

Volóchinov [...] também identifica ideologia com o universo da produção imaterial humana. Diz ele que [...] tudo o que é ideológico (isto é, entenda-se bem, todos os produtos da cultura dita imaterial) possui significado; é, portanto, um signo. [...] O universo da criação ideológica é fundamentalmente de natureza semiótica. [...] E para Medvedev (como para todo o Círculo de Bakhtin), os signos são intrinsicamente sociais, isto é, são criados e interpretados no interior dos complexos e variados processos que caracterizam o intercambio social. [...] em outros termos, o real nunca nos é dado de forma direta, crua, em si. [...] nós nos relacionamos com um real informado em matéria significante [...] E mais: como a significação dos signos envolve sempre uma dimensão axiológica, nossa relação com o mundo é sempre atravessada por valores. Bakhtin [...] apresenta esse pressuposto do Círculo dizendo que qualquer palavra, qualquer enunciado concreto, encontra o objeto a que ele se refere já recoberto de qualificações, envolto por uma atmosfera social de discursos, por uma espécie de aura heteroglóssica. A relação do nosso dizer com as coisas, em sentido amplo do termo, nunca é direta, mas se dá sempre obliquamente: nossas palavras não tocam as coisas, mas penetram na camada de discursos sociais que recobrem as coisas. (FARACO, 2009, p. 46-47-49)

14 Considerando que, algumas vezes, o adjetivo ideológico aparece como equivalente a axiológico, é importante esclarecer que, ao entender o termo ideologia, Bakhtin se refere à cultura imaterial humana, à produção espiritual do homem (a arte, a ciência, a filosofia, a religião, a ética, a política, o direito). 
Logo, o real e a cultura imaterial são de natureza semiótica, uma vez que existem, para nós, mediados por signos. Por sua vez, estes possuem significados criados e interpretados nos processos de troca social. Nesses processos, nossa relação com o mundo está sempre atravessada por valores expressos pela palavra, pelo enunciado, os quais trazem, em si, diversos outros discursos sociais.

Colello (2007, p. 77-78), com base nesse referencial, explica que a concepção bakhtiniana sobre a natureza da linguagem é essencialmente dialógica (porque a língua, em cada enunciado, é sempre de alguém para alguém e com alguém), polifônica (porque, em quaisquer situações, os enunciados são criados com base na incorporação das múltiplas falas circulantes em um universo de falantes) e responsiva (porque dirigida ao outro, já que a linguagem pede uma resposta ou reação, ainda que seja a aceitação silenciosa).

A língua, sistema de regras e normas, histórica e culturalmente instituídas, é atualizada constantemente pela (re)construção de sentidos, o que se dá pela negociação de significados durante a interlocução. Por meio do dizer, o falante não só dá vida à língua, como também acaba se constituindo e se transformando. Assim, aprender a língua ultrapassa apreender as regras e normas para poder aplicá-las em contextos funcionais. É preciso entendê-la como instrumento constitutivo do indivíduo, e, simultaneamente, a serviço dele, uma vez que as experiências linguísticas ampliam as possibilidades de comunicação e de expressão, permitem seu uso em diversos contextos e com diferentes funções, determinam modos de inserção e de atuação social, e contribuem para a organização do pensamento, favorecendo o desenvolvimento humano.

Geraldi (1997, p. 11), a esse respeito, com base nos postulados de Bakhtin, afirma:

É a dinâmica do trabalho linguístico [...] que é relevante; por ele a linguagem se constitui marcada pela história deste fazer contínuo que a está sempre constituindo. Individualmente, nos processos interacionais de que participamos, trabalhamos na construção dos sentidos "aqui e agora", e para isso temos como "material" para este trabalho a língua que "resultou" dos trabalhos anteriores. [...] Daí compreender a língua como trabalho constitutivo dos sistemas de referência e dos sujeitos cujas consciências se formam precisamente pelo conjunto de categorias que vão incorporando, enquanto signos, nos processos interlocutivos de que participam. (GERALDI, 1997, p. 11) 
Influenciados pelo mesmo contexto histórico e referencial teórico (o materialismo dialético), Bakhtin e Vigotski se aproximam, especialmente, ao compreenderem a língua como essencial no esclarecimento das questões epistemológicas que perpassam as ciências humanas.

Refletindo sobre a contribuição de um e de outro, é possível ver como ambos concebem a linguagem mediadora entre homem e mundo, uma vez que é por meio dela que é construído o sentido das coisas. É na relação entre os homens que estes se constituem como sujeitos e constroem sua consciência pela interação e pela interlocução, as quais lhes permitem desenvolver o pensamento.

Smolka e Nogueira (2002) esclarecem que, ao discutir a mediação como constitutiva da atividade mental, Vigotski traz implícita a noção de dialogia. No entanto, é Bakhtin quem enfatiza o princípio dialógico, "destacando o caráter ideológico do signo que emerge nas interações e interlocuções histórica e culturalmente situadas". Por considerar as palavras "tecidas a partir de uma multidão de fios ideológicos", observa a linguagem não só a partir do lugar de quem fala, mas, também, de quem ouve, evidenciando a natureza dialógica e responsiva intrínseca à própria linguagem, razão pela qual "as palavras ganham significado nas relações entre as pessoas, as quais exercem sempre um papel (inter)ativo". (SMOLKA; NOGUEIRA, 2002, p. 84).

Entendendo, pois, que o universo social influencia os homens, mas não os determina, ambos os autores buscam compreender os fenômenos psíquicos e linguísticos sob uma perspectiva gregária e interativa, na qual conviver e atuar no mundo são uma condição e um direito.

Nesse sentido, considerando que a escola é o lugar em que se privilegia o acesso ao conhecimento, é precisamente nesse espaço que o domínio das letras deve contribuir para a formação de pessoas capazes de se expressar, de ler o mundo e de atuar sobre ele. 


\subsection{A contribuição da Psicogênese ${ }^{15}$}

Fundamentados na Psicologia Genética de Jean Piaget, os estudos de Ferreiro e Teberosky (1999) muito contribuíram para que fossem reformulados os paradigmas do ensino da língua escrita anteriormente concebidos, uma vez que esses estudos ressignificaram a leitura e a escrita como saberes das sociedades letradas, e, como tais, bens culturais (FERREIRO, 2001a). Logo, sua apropriação é condição fundamental para a inserção social, as possibilidades de participação e o efetivo exercício da cidadania.

Ao sustentar que a teoria de Piaget é uma teoria geral dos processos de construção de conhecimento, Ferreiro (2001a, p. 12) afirma que, embora esse pesquisador nunca tenha tematizado a perspectiva social da construção do conhecimento, reconheceu tanto a influência deste universo no desenvolvimento quanto o fato de que o conhecimento dos objetos é socialmente constituído.

Calcada nesse paradigma, a autora situa o sistema de escrita como objeto simbólico e cultural, um conjunto de marcas sobre uma superfície capaz de produzir linguagem, já que, em algum momento da história da humanidade, essas marcas foram organizadas em um sistema relacionado com o sistema da língua.

As crianças em processo de desenvolvimento também são produtoras de marcas. No entanto, o fato crucial, do ponto de vista social e escolar é que devem deparar-se com marcas que outros produziram antes sobre uma superfície: marcas que se sucedem umas às outras, em ordem linear, e que se organizam em um espaço com fronteiras definidas. [...] Essas marcas são obscuras, até que um intérprete mostre para a criança que elas têm poderes especiais: apenas olhando-as produz-se linguagem. Uma linguagem certamente diferente da linguagem que se usa face a face, com uma organização particular, com palavras que não são "as de todos os dias". Quem lê fala para o outro, mas o que diz não é sua própria palavra, mas a palavra de um "Outro" que pode desdobrar-se em muitos "Outros". Somente as práticas sociais de interpretação permitem descobrir que essas marcas sobre uma superfície são objetos simbólicos; somente as práticas sociais de interpretação transformam-nas em objetos

15 O termo psicogênese pode ser compreendido como origem, gênese ou história da aquisição de conhecimentos e funções psicológicas de cada pessoa, processo que ocorre ao longo de todo o desenvolvimento, desde os anos iniciais da infância, e aplica-se a qualquer objeto ou campo de conhecimento. No campo da aquisição da escrita, esta concepção se associa aos estudos psicogenéticos de Emília Ferreiro, Ana Teberosky e demais colaboradores, originalmente divulgados em países de língua espanhola, mas com forte impacto no Brasil, sobretudo na Educação Infantil e nos anos iniciais destinados à alfabetização. 
linguísticos. [...] A escrita existe em um contexto. (FERREIRO, 2001a, p. 10-11)

Os construtivistas, além de defender a escrita como uma prática contextualizada, demonstraram que a aquisição da língua escrita constitui um processo de desenvolvimento conceitual, que exige a compreensão da natureza da língua: um elaborado e complexo sistema de representação, contextualmente situado, construído pelo homem ao longo do tempo.

Assim, a alfabetização passou a ser entendida pela compreensão do sentido da escrita como prática social que implica no entendimento simultâneo de como funciona o sistema de escrita, o que exige do aprendiz uma apropriação conceitual desse objeto de conhecimento, e não a mera aprendizagem instrumental (codificação e decodificação) que depende de habilidades perceptuais e motoras. Nas palavras da referida autora:

Se a escrita é concebida como um código de transcrição, sua aprendizagem é concebida como a aquisição de uma técnica; se a escrita é concebida como um sistema de representação, sua aprendizagem se converte na apropriação de um novo objeto de conhecimento, ou seja, em uma aprendizagem conceitual. (FERREIRO, 1989, p.16)

Quase três décadas depois, a mesma pesquisadora retoma a defesa da escrita como objeto social, cuja apropriação depende de uma sofisticada elaboração cognitiva:

Disse que meu objeto de estudo é a escrita. Sim, mas a escrita em
movimento, esse incessante processo de reconstrução pelo qual o
sistema de marcas social e culturalmente constituído se transforma em
propriedade coletiva de cada nova geração. Para compreender esse
processo de apropriação, foi necessário renunciar à visão da escrita
como técnica (ou "código de transcrição", se preferir) e despojar-se de
toda ideia instrumental. Foi necessária tornar complexa nossa própria
concepção de escrita, para compreender o processo de alfabetização.
[...] Hoje podemos afirmar que crianças de países tão diferentes como
Brasil, Grécia, Venezuela ou Itália manifestam uma atitude reflexiva
frente à escrita. Compreendem muito cedo tratar-se de marcas com
alto valor social agregado. [...] Para os pequenos de três a cinco anos,
a escrita não é um instrumento, mas um dado do meio social que
precisa ser transformado em um observável. (FERREIRO, 2013, p. 30-
31)

O aprendiz-sujeito - que assimila informações em seus esquemas cognitivos e as ressignifica pelo contexto que o meio social lhe dá - já é capaz de pensar sobre a 
escrita antes de iniciar a escolarização, conjecturando sobre ela mesmo sem ler e escrever convencionalmente. Isso é possível graças às sucessivas construções conceituais que buscam resolver problemas cognitivos, como o que a escrita representa e de que modo o faz.

Deste modo, nesse processo, o aprendiz formula hipóteses baseadas nos conhecimentos prévios que possui, bem como nas assimilações, associações e generalizações que vai construindo em sua relação com a língua. Logo, essas hipóteses traduzem o modo como ele vai construindo internamente a compreensão sobre a organização e o funcionamento do sistema de escrita, até chegar ao entendimento de sua estrutura alfabética. Ao discorrer sobre o progresso, desvendado pela Psicogênese, Mendonça (2012, p. 4) esclarece

A pesquisa demonstrou que a reconstrução da escrita pela criança
segue uma linha regular, organizada em três grandes períodos: $1^{\circ}$ ) o
da distinção entre o modo de representação icônica (imagens) ou não
icônica (letras, números, sinais); $2^{\circ}$ ) o da construção de formas de
diferenciação, controle progressivo das variaçôes sobre o eixo
qualitativo (variedade de grafias) e o eixo quantitativo (quantidade de
grafias). Esses dois períodos configuram a fase pré-linguística ou pré-
silábica; $3^{\circ}$ ) o da fonetização da escrita, quando aparecem suas
atribuições de sonorização, iniciado pelo período silábico e terminando
no alfabético. (MENDONÇA, 2012, p. 4)

O livro intitulado "Psicogênese da língua escrita", de Emília Ferreiro e Ana Teberosky - cuja primeira edição foi publicada no Brasil no ano de 1985 -, aborda a pesquisa dessas autoras. Dentre muitos aspectos investigados, identificam e esclarecem os diferentes e progressivos níveis evidenciados no estudo junto a crianças em fase de alfabetização. São eles:

a) Pré-silábico: o aprendiz ainda não compreendeu que a escrita guarda relação com a fala, ignorando qualquer relação grafema-fonema; como "experimenta" a escrita sob formas diversas (desenhos, pseudo-letras e outros sinais gráficos), não é possível recuperá-la na leitura; além disso, sua escrita pode estar associada às características do objeto que quer representar (como se vê na escrita de BOI com muitos caracteres, já que boi é um animal de grande porte);

b) Silábico: neste momento, há um importante salto qualitativo, uma vez que a criança admite a relação entre fala e escrita. O aprendiz concebe as sílabas como segmentos das palavras e utiliza uma letra para representar cada sílaba; essa letra, no entanto, pode guardar correspondência sonora adequada ou não; assim, neste 
instante, pode-se encontrar, por exemplo, a palavra "boneca" representada de diferentes maneiras: XPT, no caso de não haver correspondência sonora qualitativa, e sim quantitativa, ou ainda, OEA, BNC, BEA, ONC, BEA quando há alguma correspondência baseada na correta relação fonema-grafema;

c) Silábico-alfabético: este representa um momento transitório em que o sujeito, percebendo a inoperância do critério silábico, acaba oscilando entre os critérios silábico (já estabilizado) e alfabético (em fase de aquisição). Assim, a palavra "boneca" pode ser grafada como BOEA, ONEA, OECA, BONCA etc.;

d) Alfabético: neste momento, o aprendiz já compreendeu o princípio alfabético da língua (a relação consoante e vogal) e, gradualmente, amplia essa compreensão para a adequada correspondência entre fonemas-grafemas; sua escrita se aproxima muito da convencional, ainda que haja omissão ou troca de letras; assim, "boneca" pode aparecer como BONECA, mas também PONECA ou BONEKA, por exemplo.

Os estudos da Psicogênese da escrita trouxeram implicações pedagógicas importantes para o processo de alfabetização, dentre os quais, destacamos:

- O papel dos erros do aluno, vistos como construtivos na medida em que podem representar "janelas" na construção de conhecimentos; são formulações fundamentais para que o professor realize intervenções oportunas;

- Por ser um processo de construção de conhecimentos, a aquisição da escrita se dá internamente e de modo particular, singular para cada aprendiz; logo, os progressos são diferentes de um para outro, embora a progressão possa seguir a mesma trajetória psicogenética;

- Há necessidade de se articular o que e como se ensina ao o que e como se aprende a ler e a escrever;

- A alfabetização constitui um processo que não se restringe à escola; visto que leitura e escrita estão presentes no mundo e o aprendiz é um sujeito pensante, que não precisa de autorização para aprender em uma ordem pré-determinada pelo professor;

- Por ser um processo de natureza conceitual, a aprendizagem da língua escrita não pode referenciar-se em exercícios motores ou de "prontidão", devendo estar associadas diretamente às práticas sociais; 
- O papel da escola é disponibilizar e criar situações oportunas para a desestabilização de hipóteses e para a concepção de outras;

- A avaliação escolar como um acompanhamento do processo de aprendizagem, sendo igualmente relevante para reorientar o processo de ensino.

A despeito dessas diretrizes, equívocos importantes se estabeleceram a partir dos estudos psicogenéticos, tal como explica novamente Mendonça (2012):

Observa-se que a teoria de Ferreiro e Teberosky é esclarecedora; contudo, informações que poderiam facilitar o trabalho do professor e beneficiar diretamente os alunos não têm sido devidamente utilizadas. Analisando a alfabetização ao longo dos últimos 20 anos, constata-se que esta teoria tem sido adotada por vários estados do Brasil como se fosse uma fórmula mágica para resolver todos os problemas relativos ao tema. [...] Na tentativa de "modernizar" os materiais, o método, a apresentação de famílias silábicas e qualquer forma de sistematização do ensino [...] houve uma tentativa de implementação da Psicogênese da língua escrita, ou seja, os organizadores de tais propostas tentaram, à luz da teoria, criar uma forma revolucionária, inovadora de alfabetização. Evidentemente, nem o construtivismo, nem a Psicogênese da língua escrita são métodos, mas ainda hoje é comum, ao se questionar um alfabetizador sobre qual é seu método de ensino, obter-se a resposta: método construtivista. (MENDONÇA, 2012, p. 6 7 , grifo do autor)

A esse respeito, Colello e Luize (2006) destacam que muitos educadores fizeram leituras reducionistas desses estudos, bem como realizaram a transposição demasiadamente direta das situações de pesquisa, o que os levou a práticas igualmente simplistas e equivocadas.

Assim, na busca por propostas e caminhos que pudessem responder aos problemas de alfabetização, surgiram os "modismos pedagógicos", práticas inadequadas derivadas da má interpretação dos princípios psicogenéticos. Apresentado por Colello e Luize (2006, p. 32), o Quadro 6, a seguir, sintetiza os principais pontos de confusão entre a teoria e a prática. 
Quadro 6 - Tendências ancoradas na compreensão periférica das diretrizes ou pela má interpretação dos princípios psicogenéticos

\begin{tabular}{|c|c|}
\hline PROPOSIÇÕES CONSTRUTIVISTAS & $\begin{array}{c}\text { TENDÊNCIAS EQUIVOCADAS E REDUCIONISTAS } \\
\text { DA TRANSPOSIÇÃO DIDÁTICA }\end{array}$ \\
\hline $\begin{array}{l}\text { Evolução psicogenética entendida como um } \\
\text { processo ativo e pessoal de elaboração } \\
\text { cognitiva, a partir de experiências vividas. }\end{array}$ & $\begin{array}{l}\checkmark \text { Ausência de intervenções pedagógicas para não } \\
\text { "atrapalhar" o processo individual de } \\
\text { aprendizagem, isto é, sem a preocupação de } \\
\text { propor e oportunizar experiências ou situações } \\
\text { favoráveis à construção de conhecimentos. }\end{array}$ \\
\hline $\begin{array}{l}\text { Construção do conhecimento a partir de } \\
\text { condições favoráveis para o envolvimento } \\
\text { pessoal, a elaboração e testagem de } \\
\text { hipóteses, a possibilidade de descoberta e } \\
\text { apropriação do saber significativo. Um } \\
\text { ensino capaz de respeitar o tempo de } \\
\text { aprendizagem, as experiências e os } \\
\text { conhecimentos já construídos pela criança, } \\
\text { compreendendo o erro como parte desse } \\
\text { processo de aprendizagem. }\end{array}$ & $\begin{array}{l}\checkmark \text { Prática pedagógica como um ativismo didático de } \\
\text { duração imprevisível, não necessariamente } \\
\text { colocando a criança como foco de intervenção } \\
\text { didática. } \\
\checkmark \text { Desconsideração do planejamento. } \\
\checkmark \text { Aceitação de qualquer tipo de erro sem o esforço } \\
\text { interpretativo para compreender a sua "lógica" ou } \\
\text { para transformá-lo em um recurso para a } \\
\text { superação das dificuldades. }\end{array}$ \\
\hline $\begin{array}{l}\text { Escrita espontânea como oportunidade de } \\
\text { produção significativa para a reflexão } \\
\text { linguística e para a constituição da autoria } \\
\text { (o aprendiz-autor). }\end{array}$ & $\begin{array}{l}\text { Deixar a criança escrever livremente, sem } \\
\text { interferências, por tempo indeterminado e sem } \\
\text { propósitos e destinatários definidos. } \\
\checkmark \quad \text { Evitar a correção ou qualquer forma de } \\
\text { intervenção textual. }\end{array}$ \\
\hline $\begin{array}{l}\text { Interlocução como recurso para a troca de } \\
\text { informações e desestabilização das } \\
\text { hipóteses construídas, favorecendo a } \\
\text { possibilidade de avanço. }\end{array}$ & $\begin{array}{l}\checkmark \text { Promoção de trabalhos em grupo, supondo a } \\
\text { interlocução como consequência necessária do } \\
\text { "agrupamento de pessoas". }\end{array}$ \\
\hline $\begin{array}{l}\text { Escrita do nome próprio como } \\
\text { conhecimento significativo que pode } \\
\text { funcionar como um referencial estável de } \\
\text { escrita na tentativa de outras produções ou } \\
\text { de reflexão sobre a língua. }\end{array}$ & $\begin{array}{l}\checkmark \text { Ensino do nome próprio como a primeira lição do } \\
\text { ano ou pré-requisito para as demais } \\
\text { aprendizagens. }\end{array}$ \\
\hline $\begin{array}{l}\text { Para aproximar a língua de seus usos } \\
\text { sociais, estímulo ao uso de vários } \\
\text { portadores textuais, em diferentes } \\
\text { possibilidades de uso, funções ou gêneros } \\
\text { de escrita. }\end{array}$ & $\begin{array}{l}\checkmark \text { Composição de livros didáticos que, pretendendo } \\
\text { substituir as cartilhas, agrupam diferentes tipos } \\
\text { textuais, mas não asseguram as especificidades } \\
\text { do portador, nem as reais situações de uso. }\end{array}$ \\
\hline $\begin{array}{l}\text { Reflexão sobre a escrita para o avanço da } \\
\text { compreensão do funcionamento desse } \\
\text { sistema linguístico. }\end{array}$ & $\begin{array}{l}\checkmark \text { Trabalhar com textos só depois de "dominada" a } \\
\text { escrita alfabética. }\end{array}$ \\
\hline
\end{tabular}

Fonte: Colello e Luize (2006). 
Novos estudos desenvolvidos na década de 1990, como é o caso das pesquisas sobre letramento, instauraram outros pontos de divergência conceitual e prática, o que nos leva à importância de se situar o tema.

\title{
3.5 Alfabetização e letramento
}

Tanto a Psicogênese, quanto a Teoria histórico-cultural contribuíram para o alargamento da concepção de alfabetização. No primeiro caso, as pesquisas lideradas por Emília Ferreiro, ao superar ideia da aprendizagem mecânica e instrumental, buscaram situar a aprendizagem da língua como processo cognitivo na inserção do sujeito na cultura escrita; no segundo caso, da perspectiva sociocultural, os trabalhos sobre letramento visaram compreender a relação entre essa aprendizagem e as práticas sociais de uso da língua.

O termo letramento, incluído no Dicionário Houaiss da Língua Portuguesa apenas em 2001, é atualmente uma referência importante para designar o processo de apropriação da leitura e da escrita em seu sentido mais amplo no contexto das práticas sociais.

Sobre a relação entre os termos alfabetismo e letramento, Mortatti (2004, p. 8385) aponta que

\begin{abstract}
A história da palavra "letramento" em nosso país inicia-se somente na década de 1980, quando foi introduzida em estudos e pesquisas acadêmicas sob influência do inglês "literacy", que, até a década de 1990, era traduzido por "alfabetização" e, mais recentemente, também por "alfabetismo". [...] Segundo o representante da UNESCO no Brasil, Jorge Werthein, vem-se gradativamente substituindo "alfabetização" por "alfabetismo", na busca tanto de melhor tradução para "literacy", quanto de ampliação do conceito de alfabetização; as múltiplas significações de "alfabetismo", por sua vez, também conduzem à pluralidade dessa noção, assim como de "analfabetismo". (MORTATTI, 2004, p. 83-85)
\end{abstract}

A temática do letramento surgiu em meio à urgência de se ampliar o conceito de alfabetização, o que se deu pela crescente complexidade da sociedade grafocêntrica, cujos apelos impunham necessidades cada vez mais variadas de práticas de leitura e de escrita, assim como pela superação do analfabetismo em massa. 
Ao traçar a evolução histórica do termo "letramento" no Brasil, Mortatti (2004) aponta que este foi utilizado, pela primeira vez, por Mary Kato, em 1986, na apresentação de seu livro intitulado "No mundo da escrita, uma perspectiva psicolinguística" (KATO, 1986). Ao fazer uso do termo de modo indireto, a autora afirma que à escola cabe formar cidadãos funcionalmente letrados "do ponto de vista tanto do crescimento cognitivo individual, quanto do atendimento a demandas de uma sociedade que prestigia a língua padrão ou a norma culta da língua" (MORTATTI, 2004, p. 87).

Em 1988, em seu livro "Adultos não alfabetizados, o avesso do avesso", Leda Tfouni situa no âmbito do social, pela primeira vez, a ocorrência do letramento, enquanto a alfabetização como pertencente ao âmbito do individual, concepção que reitera anos depois:

Enquanto a alfabetização se ocupa da aquisição da escrita por um
indivíduo, ou grupo de indivíduos, o letramento focaliza os aspectos
sócio históricos da aquisição de um sistema escrito por uma
sociedade. [...] os estudos sobre o letramento não se restringem
somente àquelas pessoas que adquiriram a escrita, isto é, os
alfabetizados. Buscam investigar também as consequências da
ausência da escrita a nível individual, mas sempre remetendo a um
social mais amplo [...] (uma vez que) a ausência, tanto quanto a
presença da escrita em uma sociedade são fatores importantes que
atuam, ao mesmo tempo, como causa e consequência de
transformações sociais, culturais e psicológicas às vezes radicais.
(TFOUNI, 2010, p. 22)

Outra obra relevante para a reflexão sobre o letramento foi a publicada por Ângela Kleiman, em 1995. Em "Os significados do letramento, uma nova perspectiva sobre a prática social da escrita", a autora esclarece que, embora o termo "letramento" não estivesse dicionarizado, o conceito a que se referia já era utilizado nos meios acadêmicos a fim de diferenciar os estudos sobre a alfabetização daqueles que abrangiam o impacto da escrita na sociedade.

Kleiman (1995, p. 19) define letramento como sendo um "conjunto de práticas sociais que usam a escrita, enquanto sistema simbólico e enquanto tecnologia, em contextos específicos" e acrescenta que

a escola, a mais importante das agências de letramento, preocupa-se não com o letramento, prática social, mas com apenas um tipo de prática de letramento, a alfabetização, o processo de aquisição de códigos (alfabético, numérico), processo geralmente concebido em 
termos de uma competência individual necessária para o sucesso e promoção na escola. (KLEIMAN, 1995, p. 20)

Referenciada nos estudos de Street (2014), a autora diferencia duas concepções de letramento. A primeira, o modelo autônomo, entende que a língua tem autonomia independentemente das condições de produção. Pressupõe que o desenvolvimento do letramento somente se dá na relação com o progresso e a mobilidade social, acrescentando que esse é o modelo que existe desde o século passado, prevalecendo e se reproduzindo atualmente. Essa ótica supõe a existência de

Uma diferença tanto de tipo quanto de grau entre sociedades maciçamente alfabetizadas e aquelas com apenas uma elite ou uma minoria letrada. Para o avanço econômico, afirma-se que um 'patamar' de letramento é necessário para o progresso social; portanto, países em desenvolvimento devem ser trazidos para esse nível. (STREET, 2014, p. 38)

A esse modelo contrapõe-se o modelo ideológico, que situa a língua na relação com o contexto, os valores e as condições de produção. Assim, não há o letramento, no singular, mas, sim, letramentos, entendidos como práticas sociais e culturalmente determinadas, as quais são também reflexo de estruturas de poder.

O letramento, em si mesmo, não promove o avanço cognitivo, a mobilidade social ou o progresso; práticas letradas são específicas ao contexto político e ideológico e suas consequências variam conforme a situação. Isso não nos leva a abandonar os esforços por difundir e desenvolver os usos e significados do letramento: de fato, nos força a questionar se 0 atual quadro teórico em que tais atividades são conduzidas é o mais proveitoso. A tarefa política, por conseguinte, é complexa: desenvolver estratégias para programas de alfabetização/letramento que lidem com a evidente variedade de necessidades letradas na sociedade contemporânea. (STREET, 2014, p. 41)

A despeito das várias definições, a obra que se tornou referência para estudos posteriores sobre o tema foi "Letramento, um tema em três gêneros", publicada em 1998, por Magda Soares ${ }^{16}$, autora que sistematizou o conceito de letramento no Brasil.

16 Antes disso, Magda Soares (1995) publicou o artigo "Língua escrita, sociedade e cultura: relações, dimensões e perspectivas", documento em que tematiza o termo "alfabetismo", utilizando-o com o mesmo sentido de "literacy". Em 2003, propôs uma releitura do mesmo artigo, e explicou que, após 1995, passou a fazer uso do termo "letramento", que foi progressivamente incorporado ao discurso de outros autores. 
Ao definir "letramento", Soares (2008; 2012) o diferencia do termo "alfabetização", sendo que esta última se refere à apropriação do sistema de escrita, isto é, à mecânica do ler e escrever; o letramento, por sua vez, é "o estado ou condição que adquire um indivíduo ou grupo social como consequência de ter-se apropriado da escrita e de suas práticas sociais" (SOARES, 2012, p. 39). Nesse sentido,

um indivíduo alfabetizado não é necessariamente um indivíduo
letrado; alfabetizado é aquele que sabe ler e escrever; já o indivíduo
letrado, é o indivíduo que vive em estado de letramento; é não só
aquele que sabe ler e escrever, mas que usa socialmente a leitura e a
escrita, pratica a leitura e a escrita, responde adequadamente às
demandas sociais de leitura e escrita. (SOARES, 2008, p. 39-40)

Esse postulado marca uma divergência importante entre as concepções de Ferreiro (1989) e de Soares (1998) a respeito da definição de letramento, pois a primeira defende que o termo alfabetização já designa, em si, a integração da aprendizagem e dos usos sociais da escrita. Assim, para que alguém se alfabetize, é imprescindível que compreenda o funcionamento do sistema no âmbito dos contextos sociais em que estes naturalmente existem; daí não haver sentido, a seu ver, empregar a palavra letramento para distinguir a construção do código e das práticas sociais em que leitura e escrita aparecem.

Vale mencionar que, embora se contraponham, essas pesquisadoras convergem no cerne da questão sobre a alfabetização, a saber: articular o domínio do ler e do escrever à inserção nas práticas sociais presentes no mundo grafocêntrico.

A partir dessas considerações, pensar no processo de alfabetização implica conceber a escrita e sua aprendizagem como o acesso a mais uma manifestação linguística, que tem um lugar de igual valor quando comparada às demais formas de comunicação, não devendo se sobrepor a elas.

\subsection{O ensino da escrita}

Com base nas concepções apresentadas até aqui, cumpre repensar a alfabetização, já que, muito frequentemente, a prática de ensino vem patinando sobre bases teóricas vagas ou incompatíveis entre si. A consequência disso, de acordo com Colello (2012), é a imprecisão de objetivos e a insegurança que se instaura entre os professores, como também a ineficiência das práticas pedagógicas e avaliativas, refletindo diferentes níveis de desajustamento metodológico. 
Somente nos contextos da escrita como prática social é possível à criança alfabetizar-se em sentido amplo, aumentando suas possibilidades de lidar com a linguagem, bem como potencializando as capacidades de "se dizer", compreender e interagir com e no mundo. E o faz na medida em que o processo de alfabetização que vivencia não nega sua inteligência, permitindo que ela investigue a escrita em seus diferentes usos e funções, no âmbito de um contexto real de sentido.

Buscando combater o artificialismo do ensino da escrita, comum a muitas escolas, é preciso, pois, reafirmar a importância das considerações de Bakhtin sobre a dialogicidade da língua. Nesse sentido, Colello (2017, p. 46-48) sintetiza, no Quadro 7 , a seguir, as principais relações entre as concepções bakhtinianas e as implicações para o ensino da língua.

Quadro 7 - Concepções de língua e suas implicações para o ensino

\begin{tabular}{|c|c|}
\hline $\begin{array}{l}\text { Concepções de língua } \\
\text { (oral ou escrita) }\end{array}$ & $\begin{array}{l}\text { Implicações para o ensino: } \\
\text { princípios pedagógicos }\end{array}$ \\
\hline $\begin{array}{l}\text { A língua é vida porque as práticas de } \\
\text { comunicação e de interação dão sentido à } \\
\text { existência tipicamente humana. }\end{array}$ & $\begin{array}{l}\text { Ensino integrado à vida: a ação docente pautada } \\
\text { por práticas interativas e pelos propósitos de } \\
\text { efetivas situações comunicativas. }\end{array}$ \\
\hline $\begin{array}{l}\text { A língua medeia a passagem do plano sensível } \\
\text { (apreensão intuitiva do mundo) para o plano } \\
\text { inteligível (a elaboração que atribui sentido ao } \\
\text { mundo). Ela é, assim, constitutiva do homem. } \\
\text { Por meio dela, o indivíduo se integra na } \\
\text { corrente comunicativa de seu mundo, } \\
\text { apreende sentidos, assumindo papéis sociais } \\
\text { e gerando a sua própria consciência. }\end{array}$ & $\begin{array}{l}\text { Ensino da língua como um direito de todos, } \\
\text { voltado para a formação humana e para a } \\
\text { inserção social do sujeito. } \\
\text { Ensino da língua como processo de construção de } \\
\text { mundo e de realidade plural de existência } \\
\text { humana. } \\
\text { Aprendizagem da língua como processo reflexivo } \\
\text { e como mecanismo de geração de consciência } \\
\text { em um contexto de valores. }\end{array}$ \\
\hline $\begin{array}{l}\text { A língua tem vida, o que caracteriza o seu } \\
\text { progressivo processo de mudança. Os eventos } \\
\text { linguísticos existem no bojo de um contexto } \\
\text { específico, sendo marcados pelo jogo de } \\
\text { valores e tensões entre o dito, o não dito e o } \\
\text { respondido. São, portanto, únicos e } \\
\text { irrepetíveis. }\end{array}$ & $\begin{array}{l}\text { Inviabilidade de conteúdos fixos, neutros e } \\
\text { independentes dos contextos de produção: } \\
\text { práticas de ensino necessariamente } \\
\text { contextualizadas. } \\
\text { Ensino voltado não para o domínio do sistema, } \\
\text { mas para o trabalho linguístico que constrói e } \\
\text { reconstrói a língua, a partir de processos } \\
\text { reflexivos e de posturas críticas. } \\
\text { Ensino da língua como prática para a } \\
\text { conscientização de valores e de significados } \\
\text { assumidos no mundo: alfabetização como prática } \\
\text { política. }\end{array}$ \\
\hline
\end{tabular}


A língua só existe em função das situações comunicativas. Ler e escrever, entendidos como propostas de negociação de sentidos, nunca são atividades solitárias, já que pressupõem a interação com o outro.

A língua como processo dialógico; a produção linguística não parte de si e não se esgota em si, já que toda palavra tem uma contrapalavra.

enunciado é a unidade significativa da língua.

A língua como conjunto de modalidades integradas: a fala, a escuta, a escrita e a leitura, associadas aos elementos extraverbais.

As práticas linguísticas pressupõem um posicionamento interlocutivo em que o sujeito é constantemente convidado a deslocar-se de si para compreender o outro, a língua e a própria realidade.

A legitimidade de todas as línguas no contexto histórico e social de suas práticas.

A pluralidade linguística nos contextos polifônicos.
Ensino calcado nas dinâmicas de escuta do professor, na interação entre os alunos e na possibilidade de construção conjunta de estratégias de produção e de interpretação.

Importância em se respeitar a intenção discursiva dos alunos e fortalecer suas posturas responsivas.

Aprendizagem da língua entendida como meta em longo prazo, pautada pelo efetivo exercício linguístico: resgate das ideias prévias ou campos de referência no universo letrado, confronto de posições, escuta de múltiplas vozes, construção de estratégias de produção e de interpretação, inserção do sujeito no contexto da cultura escrita e acesso aos diferentes campos de atividades humanas (ensino da língua articulado ao conhecimento de mundo).

Ensino direcionado das reflexões epilinguísitcas, geradas a partir da leitura do texto, para as reflexões metalinguísticas, evitando o uso de palavras soltas e de frases descontextualizadas (exercícios mecânicos de fixação das normas gramaticais).

Articulação das propostas de trabalho aos diferentes canais e tecnologias da comunicação, às diferentes línguas e práticas letradas.

Necessidade de promover o trânsito e a relação entre modalidades e práticas linguísticas.

Ensino dado pelo processo de desestabilização do sujeito: a constante necessidade de considerar outros pontos de vista, outros saberes, outras formas de se expressar, outras formas de conceber e de lidar com o mundo.

Reconhecimento e respeito às diferentes línguas, aos falantes e às diversidades culturais.

Fim das práticas de discriminação e de imposição linguísticas.

Interesse em considerar a dimensão social da língua nas práticas pedagógicas: condições, processos, estratégias e modos de produção.

Necessidade de se promover, na escola, experiências do aluno com diversidade de suportes, tipos textuais, gêneros e formas de enunciação.

Ensino da língua escrita pautado pelas múltiplas possibilidades de dizer e de interpretar.

A manifestação linguística, como recurso de expressão e de poder, tem um significado essencialmente político.
Docência como exercício de resistência às forças domesticadoras.

Ensino como prática política de luta por uma sociedade democrática. 
Sob essa ótica, não basta dominar a mecânica da alfabetização para estar em situação de alfabetismo, mas também conquistar habilidades e competências para dominar as práticas de linguagem que permitem ao indivíduo se inserir no mundo letrado com consciência e possibilidades de atuação. Isso equivale a afirmar que dominar a língua escrita implica na possibilidade de dar lugar aos seus usos e funções nas sociedades letradas.

Assim, assumindo a palavra como essência da constituição do humano, reconhecemos seu potencial simbólico e educativo como instrumento que permite a integração entre indivíduo e sociedade, dando ao indivíduo o lugar de sujeito constituído por meio das práticas discursivas e sociais.

Portanto, calcados no referencial histórico-cultural, salientamos três aspectos a respeito da língua, quais sejam: ela é viva (porque pressupõe constante diálogo entre seres cultural e historicamente situados); promove o desenvolvimento da consciência (por meio de signos criados pelos grupos sociais no processo de interação e internalizados pelo sujeito); e oportuniza a inserção e a atuação no mundo (por meio de palavras dotadas de significados).

Se essa é a compreensão de língua, o que se pode dizer sobre a prática pedagógica da língua na escola?

O que constatamos é que, apesar da preocupação existente em se encontrar as melhores alternativas para bem ensinar a ler e a escrever, muitas escolas perpetuam o fracasso escolar.

Ao avaliar essa situação, Weisz e Sanchez (1985), representando a abordagem construtivista, denunciam algumas concepções que ainda se fazem presentes no discurso educacional: a suposta culpa dos alunos (carentes e repletos de deficiências), a incompetência dos professores supostamente malformados e a escola como ambiente conservador e resistente a mudanças.

Geraldi (1997), por sua vez, com base no referencial histórico-cultural, salienta que não se pode mudar as práticas de ensino sem se alterar as concepções que as subsidiam. Por isso, como já afirmado, é preciso articular concepções e saberes (sobre a compreensão da linguagem, as metas da alfabetização, as práticas de escrita na esfera social, o entendimento acerca dos processos cognitivos e a consciência sobre do papel do professor) às práticas docentes, sem o que estaremos longe de construir um ensino de qualidade, isto é, condizente com a realidade dos alunos e com as demandas de nosso mundo. 
Sob essa perspectiva, há um consenso entre pesquisadores de diferentes referenciais teóricos (construtivistas e sócio históricos) - como Coelho (2009), Colello (2004, 2012, 2017), Geraldi (1997), Ferreiro (1989, 2002, 2013), Lerner (2002), Micotti (2013), Mortatti (2014), Soares $(2008,2012)$ e sobre a máxima de Vigotski $(2007$, p. 145): "o que se deve fazer é ensinar às crianças a linguagem escrita e não apenas a escrita de letras".

Partindo do princípio de que a escrita pressupõe o acesso a um processo de elaboração pessoal que se concretiza em práticas diversas e com propósitos definidos, é preciso propiciar às crianças, desde muito cedo, situações reais de uso linguístico. Nesse sentido, a alfabetização não pode ser considerada como uma etapa prévia, de prática artificial ou como recurso instrumental que culminaria, ao término da escolarização, na possibilidade de ler e de escrever em contextos sociais; uma etapa que, mesmo com o intuito de ensinar, nega ao sujeito "o direito de usar a escrita para dizer a própria palavra" (SOARES, 2008, p. 81).

Ferreiro (2002), ao considerar a aprendizagem da escrita como uma longa e complexa empreitada pedagógica, afirma que se alfabetiza melhor:

a) quando se permite a interpretação e produção de uma diversidade de textos (inclusive dos objetos sobre os quais o texto se realiza);

b) quando se estimulam diversos tipos de situação de interação com a língua escrita;

c) quando se enfrenta a diversidade de propósitos comunicativos e de situações funcionais vinculadas à escrita;

d) quando se reconhece a diversidade de problemas a serem enfrentados para produzir uma mensagem escrita (problemas de grafização, de organização espacial, de ortografia de palavras, de pontuação, de seleção e organização lexical, de organização textual...);

e) quando se criam espaços para que sejam assumidas diversas posições enunciativas ante o texto (autor, revisor, comentarista, avaliador, ator...), e

f) finalmente, quando se assume que a diversidade de experiências dos alunos permite enriquecer a interpretação de um texto [...]; quando a diversidade de níveis de conceituação da escrita permite situações de intercâmbio, justificação e tomada de consciência que não entropecem, mas, pelo contrário, facilitam o processo; quando assumimos que as crianças pensam sobre a escrita (e nem todas pensam o mesmo ao mesmo tempo). (FERREIRO, 2002, p. 82-83) 
Ao se pressupor o direito à voz e à palavra escrita, impõe-se aos educadores o compromisso político de favorecer aos alunos - sobretudo àqueles de classes menos favorecidas - 0 acesso à linguagem em suas múltiplas possibilidades de manifestação. Respeitando a natureza dialógica da língua escrita, cumpre instituir na escola um ensino igualmente dialógico, isto é, a escrita fundada na relação com o outro; isso significa empregar os textos não como pretextos para a aprendizagem, mas como uma produção de quem tem o que dizer, uma razão para dizer o que se tem a dizer, um alguém a quem dizer e com estratégias capazes de, efetivamente, dizer (GERALDI, 1997).

Pensar na língua construída na relação com o outro pressupõe, também, considerar a relação entre seu ensino e os processos interativos que se dão em sala de aula; a essas questões, trataremos de nos dedicar no próximo capítulo. 


\section{A INTERAÇÃO NOS PROCESSOS DE APRENDIZAGEM}

Este capítulo pretende identificar os processos interativos que ocorrem em sala de aula, focando mais especificamente a relação entre professor e alunos, entre eles e o objeto de conhecimento (neste caso, a escrita) e a relação dos alunos entre si. Objetiva ainda apontar a contribuição das diferentes dinâmicas relacionais para a aprendizagem da língua.

\subsection{Estudos sobre a interação social}

Segundo Aranha (1993), os estudos sobre o desenvolvimento humano e a interação social têm tido, historicamente, enfoques diversos, a depender da função que esta assume em diferentes abordagens teóricas.

$O$ interesse em se investigar as relações sociais interpessoais surgiu ainda no século XIX, quando se buscava compreender os efeitos dos agrupamentos sociais no comportamento humano. Assim, entre 1830 e 1930, houve uma grande produção de pesquisas que destacavam a possibilidade de se investigar cientificamente os fenômenos sociais, e apontavam que as experiências com grupos eram efetivamente importantes porque permitiam conhecer a natureza humana por meio da identificação de características comuns entre indivíduos de diferentes agrupamentos e em distintos contextos.

A autora aponta que, em decorrência da Segunda Guerra Mundial, as pesquisas sobre interação social praticamente desapareceram, voltando a se estabelecer somente após o término do confronto, sendo que antes deste período, foram poucas as investigações sobre relações interpessoais. Esse cenário mudaria apenas a partir da década de 1970, quando tais estudos tiveram grande avanço e novas tendências de pesquisa surgiram.

A primeira buscava entender os efeitos da interação no comportamento social, ora enfatizando o indivíduo, ora o ambiente, mas sempre a partir do estudo de estruturas grupais (especialmente com grupos de crianças pequenas) e do desenvolvimento de estratégias que aprimorassem as habilidades sociais.

Já na segunda tendência, a interação passa a ser compreendida como um sistema complexo, com particularidades específicas, sendo considerada como fundamental via de formação das relações entre os homens. Sob essa ótica, a 
comunicação e o diálogo ganham relevância para a compreensão do desenvolvimento das relações sociais como processo, que está em contínuo movimento dialético de influência bidirecional entre os parceiros enquanto estes interagem. Igualmente, destaca-se o efeito cumulativo das interações no desenvolvimento cognitivo e nas relações interpessoais entre os sujeitos.

Tais estudos subsidiaram a terceira tendência, a abordagem histórico-cultural, representada principalmente por Vigotski e por Leontiev. Esta direção não só está de acordo com a anterior, como também amplia suas considerações ao trazer para o cenário das relações sociais o plano interativo, entendido aqui como o contexto em que se dá a construção, por um lado, da subjetividade humana, e, por outro, da história.

O trabalho desses pesquisadores defende essencialmente que

a. o desenvolvimento humano é um processo contínuo de aquisições quantitativas e de transformações qualitativas que se dão no sujeito psicológico, a partir de suas experiências no contexto das relações sociais; b. "a estrutura humana complexa é o produto de um processo de desenvolvimento profundamente enraizado nas ligações entre história individual e história social" (Vigotski, 1984, p. 33); c. tal ligação se dá no contexto interativo, plano que permite a apreensão pelo indivíduo, tanto das propriedades estruturais dos objetos materiais e ideais, como de seu significado e função social; d. a interação homemambiente será sempre mediada pelo uso de instrumentos, como pelo uso dos sistemas de signos "criados pelas sociedades ao longo do curso da história humana, mudando a forma social e o nível de seu desenvolvimento cultural" (Vigotski, 1984, p. 8); e. a internalização dos sistemas de signos produzidos culturalmente provoca transformações comportamentais e estabelece um elo de ligação entre as formas iniciais e as mais avançadas do desenvolvimento individual; f. as funções psicológicas que emergem e se consolidam no plano intersubjetivo (ação entre sujeitos) tornam-se internalizadas, transformando-se para constituir o funcionamento interno do indivíduo (plano intra-subjetivo) (Góes, 1991); g. o plano intra-subjetivo, não sendo, desta forma, meramente uma cópia do plano externo, se caracteriza pela síntese elaborada pelo sujeito, a partir "das estratégias e conhecimentos já dominados pelo sujeito e de ocorrências no contexto interativo" (Góes, 1991, p. 18); h. ao interagir, é a subjetividade construída socialmente que se manifesta, "modificando ativamente a situação estimuladora como uma parte do processo de resposta a ela" (Vigotski, 1984, p. 15); i. desta forma, temos um sujeito que não é passivamente moldado pelo meio, nem realiza suas aquisições assentado em recursos exclusivamente individuais, mas sim um sujeito interativo que se constrói socialmente, ao mesmo tempo que participa ativamente da construção do social. (ARANHA, 1993, p. 7) 
A partir dessas considerações, fica evidente como a busca por respostas sobre o papel das interações na constituição social dos indivíduos caminha de uma visão positivista para uma outra, sistêmica e histórica, em que o estabelecimento das relações humanas perpassa - e é perpassado - pela linguagem.

Sob essa perspectiva, vale a pena compreender o significado dos processos interativos na prática escolar.

\subsection{Processos interativos na educação}

Pensar a educação em um contexto histórico e cultural nos obriga a refletir sobre as questões que mobilizam a constituição do mundo contemporâneo, especialmente no que diz respeito à temática social.

Ao abordar os dilemas do nosso tempo, Perrenoud (2000), em seu livro intitulado "As Competências para ensinar no século XXI", destaca contradições importantes com as quais todos nós temos que lidar, o que inclui a escola como instituição formativa. Assim, elenca como tensões a enfrentar as relações que se dão entre cidadania planetária e identidade local, globalização econômica e fechamento político, liberdades e desigualdades, tecnologia e humanismo, racionalidade e fanatismo, individualismo e cultura de massa, democracia e totalitarismo.

Na mesma linha de pensamento, Cortella (2015) chama a atenção para o fato de que as transformações no mundo sempre ocorreram, mas a novidade é a velocidade atual com que as mudanças se sucedem em nosso cotidiano, o que exige de nós, educadores, maior atenção quanto à formação docente e ao papel da escola, quando o que está em pauta são os princípios de ética, política e bem comum.

Indo além da premissa de que o ensino por competências e o desenvolvimento tecnológico norteariam encaminhamentos para os impasses contemporâneos, Hermann (2014) destaca o papel da Filosofia na compreensão do sentido da educação, sendo a ética o ponto fundamental que não pode ser abandonado - pelo contrário, deve colaborar para o enfrentamento dos problemas educacionais, arriscando-se a pensar e propor alternativas.

Nesse sentido, valorizando no processo formativo o papel do outro nas relações com a subjetividade, a autora busca compreender o modo como a escola trata a singularidade dos sujeitos no mundo normatizado, e o faz a partir de duas categorias: a experiência estética e o diálogo. 
Em relação à primeira, afirma que

A questão do outro interpela a educação porque as normas e princípios universais, pela sua pretensa abrangência, têm dificuldade em se deixar mesclar pelo estranho, incluir o singular e tudo aquilo que escapa às regularidades. [...] Quem procura integrar elementos de uma justificação ética com a singularidade do outro - sem abandonar as exigências de universalidade, como sugere Habermas - não pode desconsiderar o significado do outro na constituição da própria subjetividade, nem operar com modelos que provocam 0 desaparecimento da alteridade. (HERMANN, 2014, p. 23-24)

Ao considerar o diálogo como outra categoria fundamental, a autora outorga à linguagem um dos modos privilegiados de aproximação. A esse respeito, salienta a linguagem como

O modo com que nos experimentamos uns aos outros e como experimentamos as tradições históricas e as condições naturais de nossa existência e de nosso mundo. [...] Somos seres de linguagem e por isso podemos dialogar, o que significa abrirmo-nos à alteridade. Isso produz um intercambio em que ambos os participantes se modificam no jogo da pergunta e da resposta e fazem uma ampliação de horizonte, que altera o vocabulário e as crenças. O diálogo rompe com a lógica da apropriação, pois ele só se institui porque há um outro, o que supõe a disponibilidade em rever nossa base de valoração, questionada pela posição do outro. [...] O diálogo tem a condição especial de dar voz ao estranho. (HERMANN, 2014, p. 24-25)

Macedo (2005), estando de acordo com o lugar do outro e do diálogo na constituição humana, contribui com essa reflexão ressaltando que nos dias de hoje, mais do que nunca, os relacionamentos tornaram-se a grande temática do mundo atual, já que, sob a forma pela qual se organiza, desafia-nos pelo distanciamento, ao mesmo tempo em que se quer cada vez mais universalizado, globalizado e próximo.

Sendo a escola, portanto, um espaço privilegiado de convivência, o autor aponta que, tão importante quanto aprender conceitos e informações, é aprender procedimentos e atitudes, objetos de aprendizagem que se traduzem pelo "saber dizer", "saber fazer" e "saber conviver", o que implica na possibilidade de incluir-se na relação com os outros, e de fazê-lo no cotidiano, tratado, assim, como uma questão pedagógica.

Nesse sentido, é necessário rever as práticas docentes de modo que, efetivamente, possam ajudar as crianças a administrarem as diferenças, a serem cooperativas, empáticas, autônomas e comprometidas consigo, com os outros e com o mundo em que habitam. 
A esse respeito, Colello (2015) ressalta a precariedade do ser humano, em sua incompletude e impotência para enfrentar sozinho a realidade, o que o impele à interação e delineia suas possibilidades de desenvolvimento e de aprendizagem. Ademais, destaca a linguagem como principal via de relação entre os membros de um grupo, uma vez que esta fundamenta as possibilidades de participação, geração de consciência e construção cognitiva, resultado da tensão de diferentes vozes e posturas.

É, pois, pela relação dialética que singular e plural se articulam, que o "eu e o outro" se encontram, que o processo de humanização se dá, em um caminho que constitui o universal pela singularidade de cada um, também um universo.

A intervenção educativa focada simultaneamente nas esferas individual e coletiva faz sentido justamente porque a natureza social do desenvolvimento humano incide, de modo dialético, nesses dois planos: o sujeito que, pela interação com os outros, aprende e se desenvolve; o agrupamento social que, na sua dinâmica de sobrevivência e perpetuação, não fica imune à ação de cada pessoa, uma ação, por excelência, transformadora. (COLELLO, 2015, p. 340)

Entender o processo de estabelecimento de relações a partir dessa lógica situa a escola como um lugar primordial, uma vez que é o espaço do coletivo e onde as relações interpessoais deveriam se dar em um contexto especialmente cuidado e organizado a fim de que se aprenda "a ser" na relação com o outro.

Sob essa perspectiva, a ação docente se faz relevante, pois é a promotora ou não - de um ambiente escolar articulado para a construção de significados socialmente compartilhados que nos remetem à vida em grupo, em comunidade e, simultaneamente, proporciona a elaboração pessoal da construção de conhecimentos.

Tendo em vista essa dimensão da aprendizagem, Zabala (1998) aponta que as atividades propostas pelo professor são importantes, mas não por si mesmas, uma vez que o essencial de todo ensino perpassa as relações que se estabelecem entre os professores, os alunos e os conteúdos de aprendizagem. Isso porque, afirma o autor (ZABALA, 2010), as relações entre professor e alunos, e destes entre si, afetam o nível de comunicação e os vínculos afetivos que se estabelecem em aula, aspecto que favorece a aprendizagem a depender de um determinado clima de convivência. Para que o aluno possa aprender, é preciso, pois, que o professor considere suas necessidades, conte com suas contribuições e conhecimentos, auxilie-o a encontrar 
sentido no que faz, proponha desafios alcançáveis, ofereça-lhe ajudas adequadas, potencialize sua autonomia e valorize sua capacidade e esforço; igualmente, em suas propostas de trabalho, cabe ao docente promover a atividade mental auto estruturante ${ }^{17}$, a autoestima e a autoimagem positiva dos alunos, viabilizar canais de comunicação efetivos e incentivar a autoavaliação, de modo que possam regular seus processos de aprendizagem.

Frente a esse panorama, e considerando as finalidades da escola e as competências docentes, não há como deixar de investigar de que maneira as relações sociais se dão em sala de aula, bem como entender as concepções em que se fundamentam os processos interativos em classe.

\subsection{Ensino, aprendizagem e processos interativos nos contextos de sala de aula}

Visando avançar na reflexão sobre as relações que ocorrem em sala de aula, é preciso, primeiramente, definir algumas questões, tais como: Que lugar é esse? Em que medida esse espaço pode revelar interfaces entre as interações sociais e os processos de ensino e aprendizagem?

A fim de responder a essas perguntas, recorremos a Tuan (1983, p. 6), que define lugar como "espaço ocupado"; assim, "o que começa como um espaço indiferenciado, transforma-se em lugar à medida que adquire definição e significado", o que se dá pela presença do indivíduo, que lhe confere sentido e valor por meio das experiências que ali vivencia.

É precisamente nesse âmbito que a noção de sala de aula ganha sentido e se apresenta como contexto, um sistema constituído por elementos diversos (alunos, professores, conteúdos, atividades de ensino, materiais, práticas docentes, instrumentos de avaliação etc.) que estão em constante inter-relação, interagindo entre si por meio de trocas complexas responsáveis pela aprendizagem. Deste modo, é a sala de aula entendida como mais do que uma estrutura física: um lugar, um tempo e um contexto de trabalho que revela a concepção de ensino e de aprendizagem na

\footnotetext{
17 O termo refere-se à capacidade de elaborar uma representação mental do objeto de aprendizagem, interiorizando-o aos próprios esquemas de conhecimento; ocorre a partir das estratégias metacognitivas que $o$ aluno põe em jogo enquanto aprende e que the permitem assegurar-se do controle pessoal dos conhecimentos que vai construindo. (ZABALA, 1998).
} 
escola. Somente sob essa ótica é possível compreender o que, como e em que condições os alunos aprendem quando os professores ensinam.

Coll e Solé (2004) colaboram para o estudo sobre o ensino e a aprendizagem e sua relação com o contexto de sala de aula ao apontarem que o tema é recente, tendo como momento fundamental a publicação American Educational Research Association on Teaching (GAGE, 1963). Somente a partir desse trabalho novas linhas de pesquisa em Psicologia da Educação avançaram, tendo sido as últimas quatro décadas do século XX marcadas por intensas e profundas modificações em formulações teóricas e metodológicas que buscavam melhor compreender as relações entre os processos de aprendizagem que se desencadeiam por conta do ensino.

Constituindo-se como um terreno de criação e de modificação dos processos de ensino e aprendizagem, a sala de aula denota uma estrutura complexa, em que as atividades realizadas por professores e alunos estão invariavelmente marcadas por características específicas, como a multidimensionalidade e a simultaneidade (a presença de muitas coisas ao mesmo tempo), o imediatismo (tudo ocorre muito rapidamente), a imprevisibilidade (não é possível prever e planejar tudo), a publicidade (tudo o que professor e alunos fazem se torna público ali) e a historicidade (o que ocorre em uma aula decorre, em boa medida, do que se deu em aulas anteriores). Tais características circundam e influenciam a atuação de professores e de alunos, e expressam muito do que e como os professores ensinam, bem como do que e como os alunos aprendem.

Foi somente a partir da década de 1980 que aquilo que ocorria em sala de aula passou a ser relevante para se entender os processos de ensino e aprendizagem, o que foi possível por meio da análise das variáveis contextuais que incidem nas dinâmicas em que se dão esses processos.

Assim, na intenção de identificar e de analisar as formas básicas de compreender essas relações, Coll e Solé (2004) apontam paradigmas historicamente identificáveis e que são tributários de concepções de ensino e aprendizagem.

Durante muito tempo, o sucesso da aprendizagem dos alunos residia especificamente na figura do professor, que deveria ser eficiente na transmissão dos conteúdos; ao aluno, cabia o lugar de receptor passivo, cujos resultados da aprendizagem eram consequência direta da eficiência do ensino do professor. Esse é o princípio do Empirismo, discutido anteriormente. Com o tempo, a ideia de um 
professor eficiente foi se transformando: de início, o que o definia eram suas características pessoais e de temperamento; a partir dos anos 1950, no entanto, este seria caracterizado por seus comportamentos; o que mudaria novamente em meados da década de 1970, quando um bom professor passou a ser identificado por metodologias de ensino que empregava. Em seguida, as concepções pedagógicas configuraram-se como mais relevantes para a ação docente, sendo entendidas como os processos psicológicos "encobertos", implícitos em sua ação, uma vez que não são observáveis.

Ainda na posição de centro dos processos de ensino e aprendizagem, o professor, posteriormente, ganha relevância pela relação "processo-produto", situação em que se observa que os resultados do protagonismo docente variam conforme as características dos alunos, dos conteúdos de ensino e dos contextos de sala de aula. Sob esse paradigma, o que importa é investigar, estatisticamente, as variáveis existentes nas metodologias didáticas e o êxito que os alunos obtêm em relação aos objetivos educacionais previamente estabelecidos.

Somente a partir da década de 1980 é que o aluno ganhou protagonismo no cenário educativo, sendo visto como principal responsável por sua aprendizagem, a qual resulta das relações estabelecidas entre ele e o objeto de conhecimento. Um novo paradigma se estabelece: pela atividade mental "encoberta", não visível, o aluno constrói conhecimentos pela elaboração do pensamento (e não mais pelo acúmulo de informações), processo em que reestrutura esquemas cognitivos e produz significado aos conteúdos escolares, em uma atividade auto estruturante. Sob essa ótica, o professor passa a ter um outro papel em sala de aula, cabendo-lhe apenas planejar e intermediar o encontro entre o aluno e o objeto a ser conhecido.

Essa mudança radical de pressupostos alterou a leitura dos marcos conceituais presentes até então, de forma a passar a ênfase do ensino para a aprendizagem e os processos psíquicos subjacentes, o que chamou a atenção dos estudiosos para a importância de se levar em conta as formulações de hipóteses dos alunos; contudo, essa posição ainda não daria conta de analisar os processos de ensino e aprendizagem de modo articulado.

Na década de 1980, novas perspectivas teóricas se delineiam, provocando uma profunda mudança paradigmática sobre as concepções de aprendizagem, cognição e ensino. 
Em primeiro lugar, os enfoques construtivistas marcam as pesquisas do último terço do século XX e apontaram o protagonismo compartilhado entre professor e aluno como elementos-chave para a compreensão da aprendizagem, conforme já apresentado no segundo capítulo. Nessa concepção, ensino e aprendizagem são aspectos complementares e indissociáveis de um mesmo processo, e a análise feita em separado não permite compreender e melhorar as práticas educacionais. Considera-se, aqui, que o aluno não é receptor passivo, pois constrói conhecimentos, e o faz não somente a partir da cognição, mas, também, pelos processos psicológicos subjacentes (afetivos, emocionais e motivacionais), relevantes para que se dê a aprendizagem.

Aliada a essa postura, vale destacar a mudança qualitativa que se dá quando as pesquisas trazem à tona o "triângulo didático": o conteúdo, o ensino e a aprendizagem realizada pelos alunos. Sob essa perspectiva, Nóvoa (2000) esclarece que, para se compreender o que ocorre em sala de aula, é preciso analisar as interrelações existentes entre conteúdos de ensino, ação docente e atividades de aprendizagem realizadas pelos alunos, as quais se organizam sob diferentes formatos, definidos como "segmentos de atividades".

Em segundo lugar, vale considerar as contribuições das ideias de Vigotski e da Teoria histórico-cultural, que põem em dúvida a existência dos processos psicológicos como propriedade das mentes individuais. Esse questionamento levou a uma nova conceitualização, em que ensino e aprendizagem constituem um processo essencialmente cultural, social e interpessoal, uma vez que é na interação entre as pessoas que a aprendizagem efetivamente se dá. Nesse sentido, as comunidades de prática e de aprendizagem das quais os sujeitos fazem parte são determinantes, uma vez que "professor e alunos se envolvem juntos e em colaboração com uma série de atividades mediante as quais vão co-construindo progressivamente significados compartilhados sobre os conteúdos e as tarefas escolares" (COLL; SOLÉ, 2004, p. 258). Assim, o que importa não é a análise das atividades e das tarefas escolares em si, mas sim a ação conjunta em que professor e alunos constroem as atividades, de modo que a aprendizagem se concretiza.

$O$ terceiro ponto diz respeito à função essencial da linguagem como instrumento do pensamento; sem desconsiderar sua função comunicativa, que destaca a importância das trocas dialógicas e da conversação em sala de aula (que professor e alunos utilizam para trocar informações, fazer e responder perguntas, 
formular instruções e colocar exigências, por exemplo), há, aqui, uma mudança teórica fundamental: a linguagem, dotada de enorme potencial como instrumento semiótico, permite criar, transformar e socializar significados, os quais possibilitam que professor e alunos construam, em uma atividade conjunta, o conhecimento sobre os conteúdos escolares. Decorre daí a necessidade de se analisar o discurso presente em sala de aula como uma das chaves para entender os processos de ensino e aprendizagem.

A esse respeito vale destacar as considerações tecidas por Davis, Silva e Espósito (1989, p. 52), que apontam a necessidade de se analisar criticamente as interações sociais, uma vez que nem todas podem ser consideradas formativas; além disso, ressaltam que seu valor educativo decorre da potencialidade que apresentam para provocar a construção de conhecimento entre aqueles que estão interagindo.

Este processo de construção, por se manifestar na e pela interação
social, adquire "visibilidade". Esta "visibilidade", por sua vez, promove
um alargamento da capacidade cognitiva individual, na medida em que
propiciou a realização em conjunto daquilo que sozinho não seria
realizado. A interação com o outro, seja ele um adulto ou uma criança
mais experiente, adquire, assim, um caráter estruturante na
construção do conhecimento na medida em que fornece, além da
dimensão afetiva, desafio e apoio para a atividade cognitiva. A
interaçãa social atua, desta forma, sobre a zona de desenvolvimento
potencial, fazendo com que processos maturacionais em andamento
venham a se completar, fornecendo novas bases para novas
aprendizagens. Interações sociais que contribuem para a construção
do saber e que, por esta razão, são consideradas educativas referem-
se, pois, a situações bem específicas: aquelas que exigem
coordenaçãão de conhecimentos, articulação de ação, superação de
contradições etc. (DAVIS; SILVA; ESPÓSITO, 1989, p. 52)

Com vistas às interações que promovem a construção de saberes, a autora propõe a análise das modalidades interativas presentes nas diferentes pedagogias. Destaca que, na pedagogia tradicional, privilegia-se a interação social entre professor e aluno pelo pressuposto da transmissão de conhecimentos do mais sábio e experiente para o menos competente. Em uma relação assimétrica, o professor (mais velho, mais experiente e mais sábio) tem seu poder legitimado sobre os alunos, que devem passivamente obedecê-lo.

$\mathrm{Na}$ mesma linha de argumentação, Mizukami (2013) esclarece que, nesta vertente, a educação encontra-se subordinada à instrução, e a aprendizagem do aluno é vista como um fim em si mesmo, uma vez que os conteúdos devem ser "adquiridos" e, os modelos, imitados. Ao se preocupar com a variedade e a quantidade de 
conceitos e de informações, o professor fica focado na sistematização de conhecimentos de forma acabada, propondo tarefas padronizadas. Este ensino se caracteriza pelo verbalismo unilateral (do professor para o aluno) e pela memorização (por parte do aluno). Nesse cenário, as relações sociais entre os alunos são quase suprimidas, prevalecendo a interação professor-aluno. A classe consiste, então, na justaposição dessas relações, duais e paralelas, inibindo a constituição de um grupo que interaja para a efetiva construção de conhecimentos. A metodologia adotada baseia-se, prioritariamente, na exposição docente e nas demonstrações feitas à classe, tida como um auditório. O professor já traz, previamente, o conteúdo pronto, e o aluno deve escutá-lo e absorvê-lo, reproduzindo o que ouviu. São reprimidas manifestações afetivas por serem entendidas como possíveis impedimentos para a aprendizagem.

Em uma vertente aparentemente diferente, mas igualmente diretiva, pretendese superar o verbalismo do professor e provocar certa atividade discente: pelo método "maiêutico", o professor faz uso de perguntas aos alunos de modo a induzir suas respostas a um resultado desejado. Há uma troca intensa entre professor e alunos, mas as perguntas formuladas visam a padrões de respostas que conduzam à informação exata que se deseja atingir. Dado que os alunos terminam por chegar às respostas corretas por meio das perguntas indutivas do professor, ele infere que tenha havido uma suposta eficiência na aprendizagem.

Na contramão da pedagogia tradicional, Davis, Silva e Espósito (1989) apontam que muitos professores passaram a enfatizar as relações simétricas - isto é, aquelas que se estabelecem entre os alunos - como possibilidade de superar o "autoritarismo" docente. O efeito dessa visão, no entanto, é igualmente inapropriado, pois, na intenção de não inibir a criatividade, a curiosidade e a confiança dos alunos, o professor abre mão de sua autoridade, deixando-os à deriva, por acreditar que as interações criança-criança são necessariamente produtivas e produtoras de autonomia no pensar e no agir, o que não se legitima.

Mizukami (2013) acrescenta que, nessa abordagem (humanista/ espontaneísta), o papel assumido pelo professor é de "facilitador" da aprendizagem; ao aceitar o aluno como é e ao compreender seus sentimentos e possibilidades, o docente oportunizará um clima favorável para que o aluno aprenda o que tem significado para ele. 
A característica básica dessa abordagem, no que se refere ao que ocorre em sala de aula, é a ênfase atribuída à relação pedagógica, a um clima favorável ao desenvolvimento das pessoas, ao desenvolvimento de um clima que possibilite a liberdade par aprender. Isso é decorrência de uma atitude de respeito incondicional pela pessoa do outro, considerada capaz de se auto dirigir. (MIZUKAMI, 2013, p. 52-55)

Davis, Silva e Espósito (1989), por sua vez, salientam que a vertente sociointeracionista aborda de modo bastante diverso a questão, pois parte do princípio de que os sujeitos são diferentes e essa diversidade é elemento fundamental para a interação que ocorre em sala de aula, uma vez que a desigualdade é promotora de trocas e, consequentemente, favorece a desestabilização de concepções prévias, assim como a ampliação das capacidades cognitivas e sociais.

Nesse sentido, a questão não é a simetria das relações, haja vista ela não existe, de fato: as relações entre professor e alunos e entre os alunos são sempre assimétricas. Trata-se de enfatizar que

O valor da simetria não está, portanto, em eliminar as desigualdades, mesmo porque isso seria uma impossibilidade prática. Seu valor, ao contrário, está no fato de garantir condições simétricas de participação- condições de participação igualitárias- onde contribuições distintas são vistas como necessárias para se atingir um objetivo comum. (DAVIS; SILVA; ESPÓSITO, 1989, p. 53)

Partindo desse princípio, cabe ao professor garantir condições para que os alunos trabalhem em cooperação e colaboração, a partir da compreensão mútua e da comunicação produtiva; somente assim as interações sociais em sala de aula se tornam formativas.

Considerado um dos interlocutores no diálogo em torno da construção do conhecimento, também cabe ao docente promover fecundas situações de aprendizagem, ou seja, atividades em que os alunos possam apropriar-se, aplicar e reestruturar conhecimentos por meio de uma comunicação e intervenção ágil e produtiva.

Oliveira (1997) enfatiza as implicações da concepção vigotskiana na intervenção pedagógica, uma vez que, se o aprendizado impulsiona o desenvolvimento, o processo de ensino e aprendizagem deve incidir na Zona de Desenvolvimento Real do aluno e caminhar rumo à Zona de Desenvolvimento Potencial. Nesse processo, é essencial a intervenção docente na relação com o aluno 
para provocar avanços que não ocorreriam espontaneamente; do mesmo modo, a interação entre as crianças é fundamental, pois é por meio dela que os alunos compartilham e ressignificam elementos de sua cultura, construindo e reconstruindo conhecimentos. Visto que os saberes dos alunos são diferentes, as trocas de informações e de estratégias de pensamento entre eles são bem-vindas, já que também podem ser mediadores legítimos nos processos interativos.

Ambas as pesquisadoras salientam a interação entre os alunos e, destes, com o professor como fator determinante para a construção de novos conhecimentos, habilidades e significações.

Os comportamentos do professor e dos alunos estão, portanto, dispostos em uma rede de interações envolvendo comunicação e complementação de papéis em que expectativas recíprocas são colocadas. [...] Comportamentos como perguntar, expor, incentivar, escutar, coordenar e participar de debates, explicar, ilustrar e outros podem ser expressos pelos alunos e pelo professor numa rede de participações onde os indivíduos consideram-se, reciprocamente, como interlocutores que constroem o conhecimento pelo diálogo. (DAVIS; OLIVEIRA, 2010, p. 113-114)

\subsection{Agrupamentos e dinâmicas relacionais}

Segundo a estrutura de gestão que assumem, é possível situar diversas formas de agrupamentos nas escolas. De acordo com Zabala (1998), as diferentes classificações são determinadas por seu âmbito de intervenção (grupo/escola e grupo/classe), estando cada uma delas baseada em critérios que consideram a heterogeneidade e a homogeneidade presentes entre os integrantes.

Uma questão que aí se coloca é se prevalecerá entre os alunos o princípio da homogeneidade ou o da heterogeneidade, especialmente em relação aos níveis de desenvolvimento e de conhecimento, o que leva a pensar nas implicações da adoção de um modelo ou de outro. Zabala (1998) ressalta que uma possibilidade para se avançar na questão é o estabelecimento de ciclos de aprendizagem, que permitem proposições mais amplas e globais no que se refere ao desenvolvimento dos alunos.

Em relação à dinâmica de trabalho desenvolvido em sala de aula com os alunos, é possível encontrar grupos-classe móveis ou flexíveis, que permitem a organização de atividades e de áreas em diferentes ambientes (como as salas multiuso, salas-ambiente e oficinas) e com professores diversos. Nesse sistema, cada aluno pertence a tantos grupos quantas sejam as atividades ou áreas de 
conhecimento/disciplinas que configuram seu trajeto escolar; também é possível mesclar alunos de diferentes idades e que pertencem a diversas classes. Com essa forma de organização, mais personalizada, é possível atender melhor aos interesses e às demandas de aprendizagem dos alunos, o que favorece seu protagonismo no processo educativo. Em contrapartida, esse modelo apresenta certa dificuldade organizativa, além de não ser favorável para que cada aluno se sinta pertencente a um grupo estável de trabalho.

Historicamente, o modo mais comum de organização das atividades em sala de aula define que todos os alunos façam a mesma tarefa e ao mesmo tempo, proposta mais condizente com um sistema diretivo e empirista, que inibe o ensino capaz de respeitar as diferenças individuais.

Outra possibilidade de agrupamento considera dividir a turma em equipes fixas, em que meninos e meninas são distribuídos em grupos de, aproximadamente, cinco a oito alunos, durante um período previamente definido, e no qual cada membro tem uma tarefa ou função específica a desempenhar, o que poderia favorecer a autonomia dos alunos.

As equipes fixas têm duas funções básicas: a primeira é organizativa e define cargos e funções pelos quais cada membro fica responsável; a segunda é de convivência e leva em consideração a diversidade entre os membros e os vínculos afetivos presentes nas interações que podem favorecer a empatia, a colaboração e o respeito às diferenças.

Também é possível organizar as classes em equipes móveis ou flexíveis, com a finalidade de desenvolver uma tarefa específica; a duração desses agrupamentos está atrelada ao tempo de realização da atividade em questão. $O$ trabalho organizado em pequenos grupos permite ao professor atender às demandas dos alunos, assim como propor tarefas que estejam de acordo com seus interesses e possibilidades.

É o caso das Atividades Diversificadas e dos "Cantos", por exemplo, frequentemente presentes na Educação Infantil, configuração em que o professor pode oferecer ajudas específicas sem comprometer o trabalho do restante do grupo. Nessa estrutura, os alunos podem se beneficiar pela coordenação de perspectivas diferentes e pela possibilidade de dar e de receber ajuda dos colegas.

O trabalho individual pode se configurar como uma situação potente quando o aluno, tendo compreendido um conceito, realiza atividades de sistematização, ou seja, aquelas que lhe permitem ampliar, detalhar, recordar e reforçar o que já havia 
apreendido. É uma modalidade interessante para a assimilação de fatos, para o aprofundamento de conceitos e, especialmente, para a sistematização de procedimentos.

Castorina et al. (2006) apontam que, quando a classe se organiza em pequenos grupos, nem sempre o trabalho em grupos garante a construção de conhecimento, pois pode acontecer de alguém permanecer à margem da interação ou se limitar a simplesmente apoiar o que fazem os demais.

Para que o trabalho desenvolvido em grupos tenha êxito, é importante que apresente condições capazes de favorecer uma interação produtiva tais como:

- Grupos pequenos, de modo a permitir que a responsabilidade entre os membros se dilua e cada um se sinta comprometido com o trabalho feito em conjunto;

- Tempo para se pensar individualmente no problema antes de intercambiar ideias com os pares, o que permite aos alunos dispor de algo para contribuir;

- Diferentes níveis de conhecimento, a fim de promover avanços na aprendizagem.

Compartilhando a mesma perspectiva, Colello (2015, p. 347) aponta que, como "o mero ajuntamento de pessoas (como é o caso de tantas salas de aula) nem sempre garante práticas interlocutivas de efetivo intercâmbio, dialogia e reflexão, é preciso que se estabeleça uma diferenciação entre trabalhos em grupo e trabalhos colaborativos".

Os trabalhos em grupo podem se configurar como uma junção de pessoas que não têm, necessariamente, compromisso com os demais membros do grupo ou articulação funcional para a realização da tarefa, o que frequentemente traz à tona lógicas individualistas, em que cada um faz sua parte sem possuir a dimensão do todo.

Como aponta a referida autora, nas práticas colaborativas, em contrapartida, há oportunidades que qualificam a experiência vivida e justificam o planejamento das atividades em razão da garantia de condições específicas, tais como: 
- estimulação de práticas comunicativas;

- estabelecimento de situações concretas de interlocução e de razões objetivas para fazer uso do conhecimento;

- propostas voltadas para o aumento da motivação e da disponibilidade para aprender;

- circulação significativa de informações, abrindo, inclusive, a possibilidade de as crianças considerarem aspectos que antes não eram percebidos (experiências transformadoras);

- possibilidade de troca de saberes e de estratégias por meio de efetiva interlocução intelectual;

- aproximação com outros campos de conhecimento e esferas de ação;

- organização e sistematização dos saberes, criando mecanismos para recapitular;

- estabelecimento de situações concretas de interlocução e de razões objetivas para fazer uso do conhecimento;

- propostas voltadas para o aumento da motivação e da disponibilidade para aprender;

- circulação significativa de informações, abrindo, inclusive, a possibilidade de as crianças considerarem aspectos que antes não eram percebidos (experiências transformadoras);

- possibilidade de troca de saberes e de estratégias por meio de efetiva interlocução intelectual;

- aproximação com outros campos de conhecimento e esferas de ação;

- organização e sistematização dos saberes, criando mecanismos para recapitular e sintetizar informações;

- experiência de escuta, de consideração de outros pontos de vista e de exercício da tolerância;

- exposição a diferentes argumentações;

- oportunidades privilegiadas para lidar com a inclusão e a heterogeneidade do grupo: o envolvimento de todos em uma mesma atividade e a participação diferenciada conforme as possibilidades de cada um;

- ampliação das estratégias cognitivas na direção da autonomia de pensamento devido às oportunidades de tomada de consciência dos processos de aprendizagem;

- vivência de conflitos que, ao desautomatizar procedimentos e desestabilizar posturas ou hipóteses, remetem ao reconhecimento de dificuldades ou das deficiências das ideias prévias e, por essa via, provocam também modificações na estruturação cognitiva e resolução de problemas;

- exploração de variadas frentes de reflexão sobre um dado conteúdo, gerando a consciência sobre a complexidade do mundo;

- promoção de atividade mental auto estruturante, isto é, apoiada em mecanismos de delinear agrupamentos, estabelecer relações, favorecer comparações, pensar de modo descontextualizado, usar o raciocínio lógico e generalizar conhecimentos;

- oportunidades para evocar conhecimentos prévios, expor, defender e justificar os próprios pontos de vista;

chance de refazer procedimentos, raciocínios, testar e comprovar hipóteses; 
- necessidade de posicionamento pessoal responsável e comprometido em relação ao grupo ou ao objeto em questão;

- desenvolvimento de competências na organização de trabalhos colaborativos e na sistemática de tarefas realizadas em equipe (situações de regulagem mútua tais como divisão funcional de tarefas, coordenação de iniciativas;

- tomada conjunta de decisões, atividades de complementação etc.);

- compartilhamento de experiências estéticas, que favorecem o despertar do gosto em campos desconhecidos como o da arte e da literatura;

- mediação para saberes técnicos e instrumentais como modos de acesso e trânsito no universo virtual;

- exercício de avaliar os outros e a si mesmo;

- valorização do saber pelo reconhecimento de sentidos, funcionalidades e valores que a ele se agregam;

- experiência de pedir ou prestar ajuda;

- vivência em contextos democráticos. (COLELLO, 2015, p. 347-349)

Vem daí o interesse em compreender as possibilidades das dinâmicas interacionais na escola.

\subsection{Alfabetização e Letramento em contextos interativos}

Com o intuito de construir propostas que busquem o aprendizado da língua escrita como práticas sociais de linguagem, há uma demanda de deslocamento da língua de objeto social para objeto de estudo e aprendizagem; na prática, isso significa que "a atitude de reflexão sobre a linguagem inverte a prática corrente no ensino, tomando as atividades epilinguísitcas como fonte ou ponto de partida para reflexões mais aprofundadas." (GERALDI, 1997, p. 217).

Bortolotto (1998) e também Nogueira e Nogueira (2017) contribuem com essa reflexão ao apontarem que é preciso que o professor atue na construção de práticas de alfabetização que intensifiquem o movimento discursivo de trabalho na/de linguagem, o que significa que as produções textuais - coletivas e individuais propostas aos alunos devem se aproximar, ao máximo, das reais condições de produção. Além disso, é fundamental que sua fala não preceda ou se sobreponha à do aluno, tampouco o exponha a enunciações repetidas e perguntas circulares, ou a referenciais que comprometam o processo interlocutivo.

As pessoas envolvidas precisam estar em coenunciação, sem que já esteja definido, a priori, quem tem direito à voz (geralmente o professor), ou quais 
enunciados serão ou não aceitos, sem que a criança tenha que se ocupar, previamente, de responder "o certo" ou "o que o professor deseja ouvir".

É necessário que haja equidade de papéis entre o discurso de professor e alunos, bem como destes entre si. Há um saber não só sobre objetos, coisas, fatos, mas sobre o próprio "contar" e escrever que poderia monitorar novas atitudes, estabelecer novos espaços discursivos nesta relação que, propondo-se ser de ensino e de aprendizagem, deveria ser via de mão dupla. (BORTOLOTTO, 1998, p. 77)

Assim sendo, ao conceber a aprendizagem da língua como um processo discursivo e dialógico, cabe ao professor investigar quais são as melhores condições que geram interações produtivas entre os alunos enquanto escrevem, seja antes de terem se apropriado do funcionamento do sistema alfabético, seja posteriormente, bem como nas situações de leitura.

Lerner (2006) aponta que as interações mais produtivas ocorrem quando os membros de um grupo de trabalho possuem suficientes conhecimentos em comum para se entenderem e discrepâncias o bastante para poderem comparar suas ideias e, assim, colaborar mutuamente na construção linguística.

Ao acompanhar a interação entre pares de alunos, cabe ao professor promovêla e coordená-la de modo a orientar o processo em direção aos saberes que as crianças devem construir.

$\mathrm{Na}$ relação com os alunos que escrevem em situações concretas, vinculadas às práticas sociais, o professor cumpre essa função sendo um informante privilegiado, escrevendo junto às crianças e com elas, bem como lhes propondo estratégias de trabalho. Também escreve e compartilha com elas os problemas que surgem enquanto se escreve, bem como a reflexão sobre as possíveis soluções.

Ainda segundo Lerner (2006), o professor também promove interações produtivas quando:

- lê com os alunos um texto difícil e os ajuda a descobrir o que podem entender sozinhos e o que aprendem conversando;

- contribui com os alunos orientando-os na busca de propósitos leitores e partilha com eles perguntas que um leitor se faz referentes ao texto, ressaltando possíveis relações com outros textos;

- fornece informações que seus alunos ainda não possuem e que lhes permitem compreender melhor o material lido; 
- compartilha inquietações com outros leitores a partir de indicações literárias, recomendações de leitura;

- ajuda as crianças a elaborar estratégias e a se apropriarem delas;

- recomenda que recorram a materiais escritos como fontes de consulta para escritas futuras.

\subsection{Interação na escola}

A relevância de interações e relações sociais produtivas para a construção de conhecimentos e de valores fica evidente a partir das considerações tecidas até aqui. Contudo, Colello (2015) salienta que, em muitas escolas, prevalecem práticas unidirecionais e pouco interativas, baseadas em uma lógica individualista e com estratégias isolacionistas dos sujeitos, isto é, com reduzidas possibilidades de interlocução. Isso se deve a dois fatores, a saber: a natureza das concepções docentes; e, em decorrência delas, a dificuldade em garantir boas condições para que os grupos interativos funcionem.

Ademais, a autora aponta que as seguintes crenças também comprometem o uso de estratégias colaborativas (COLELLO, 2015):

- o professor é o único informante legítimo, o que lhe confere o papel central de transmitir conhecimentos aos alunos;

- os saberes prévios dos alunos e seu papel de sujeitos ativos na construção de conhecimentos não Ihes conferem a possibilidade de provocar conflitos favoráveis ao avanço cognitivo;

- como todos os alunos pertencem ao mesmo ano escolar, supostamente possuem o mesmo nível de competência; logo, o intercâmbio entre eles não se justificaria;

- as diferenças e as desigualdades entre os saberes devem ser suprimidas, em nome do ideal de homogeneidade de saberes e de comportamentos entre os alunos;

- os alunos, ao aprenderem, enfrentam dilemas e dificuldades muito semelhantes, o que justificaria sustentar dinâmicas padronizadas de ensino;

- as demandas individuais de aprendizagem (nas concepções que diferem do tópico anterior) requerem um ensino individualizado, com atividades diferentes a cada aluno, adaptadas ao seu próprio ritmo de aprendizagem; 
- o pressuposto de que "os mais avançados devem ter paciência com os mais atrasados" justifica que a melhor maneira de equacionar a situação seria lançar mão de proposições balizadas "pela média" da turma;

- a crença de que os alunos que se encontram em níveis próximos de conhecimento podem não avançar na aprendizagem quando trabalham juntos, já que não têm como agregar nada um ao outro, reforça a opção por se realizar um trabalho individual;

- a suposição de que os alunos que se encontram em níveis diferentes de conhecimento não podem trabalhar juntos, para que não sejam prejudicados os mais avançados;

- a centralização e a condução diretiva do trabalho em sala de aula são importantes para afastar a possibilidade de situações imprevistas, que podem comprometer o programa de ensino;

- as práticas interativas podem favorecer a distração e a indisciplina entre os alunos, razão pela qual é fundamental que o professor mantenha o silêncio e o controle sobre eles, propondo práticas individuais de trabalho;

- as práticas interativas podem criar ou acirrar conflitos existentes entre os alunos, em função da intolerância de muitos frente à divergência de ideias.

Tendo sido evidenciadas as premissas que sustentam as concepções docentes que muito frequentemente vigoram em sala de aula, bem como os argumentos em que se fundamenta a conceitualização dialógica da língua, situamos os pressupostos da presente pesquisa sem a intenção de esgotar o tema, e salientamos como o ensino da língua enquanto prática social de linguagem depende de processos interativos presentes em sala de aula. Apontamos, com igual relevância, o papel do professor, que, sendo o mediador entre os alunos e o objeto a ser conhecido, deve propor situações didáticas que promovam interlocução produtiva e reflexiva entre os aprendentes da língua escrita.

Com o objetivo de dar continuidade ao projeto de investigação exposto até aqui, no próximo capítulo projetaremos este estudo, propriamente. 


\section{DELINEANDO O PROCESSO DE PESQUISA}

Neste capítulo apresentamos a estrutura da presente pesquisa, explicitando o problema a ser investigado, bem como os objetivos e a metodologia do estudo. Apontaremos também o levantamento e a perspectiva de análise dos dados coletados em função dos eixos e âmbitos de investigação.

\subsection{Problema, justificativa, hipótese e objetivos}

Refletir sobre a contradição que existe entre o avanço das pesquisas e a educação formal, que nem sempre atinge seus objetivos, é relevante para se compreender o cenário educacional. Isso porque, como se sabe, o resultado da avaliação do desempenho escolar no Brasil está aquém do desejável, como comprovam as avaliações realizadas pelo SAEB ${ }^{18}$, SARESP ${ }^{19}$, ANA $^{20}$ e PISA $^{21}$.

Esse panorama nos incita a buscar respostas para um problema que se impõe, o qual pode ser representado pelas seguintes indagações: Qual a relação entre os avanços teóricos, as concepções docentes sobre o ensino da língua escrita e as práticas de ensino? Como as concepções docentes e as práticas pedagógicas relativas ao ensino da língua escrita incorporam as diretrizes assumidas?

Considerando a relevância do problema, elegemos o ensino da língua escrita como objeto de investigação, e, a seguir, destacamos as justificativas mais específicas que nos conduziram à realização deste estudo.

Diversos são os programas de formação de professores que têm investido esforços para capacitar docentes no ensino da língua escrita, buscando aportes teóricos capazes de subsidiar sua prática; no entanto, os resultados obtidos não

${ }^{18}$ Avaliação constituída por provas de Língua Portuguesa e de Matemática; destina-se aos estudantes

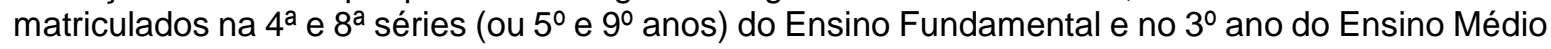
das redes públicas e privadas do país.

${ }^{19}$ Avaliação em que os alunos do $3^{\circ}, 5^{\circ}, 7^{\circ}$ e $9^{\circ}$ anos do Ensino Fundamental e do $3^{\circ}$ ano do Ensino Médio têm seus conhecimentos verificados por meio de provas com questões de Língua Portuguesa, Matemática, Ciências Humanas, Ciências da Natureza e redação.

${ }^{20}$ Avaliação que objetiva aferir os níveis de alfabetização e de letramento em Língua Portuguesa (leitura e escrita) e em Matemática dos estudantes do $3^{\circ}$ ano do Ensino Fundamental das escolas públicas.

${ }^{21}$ O Programa Internacional de Avaliação de Estudantes (PISA) constitui uma avaliação comparativa internacional, realizada a cada três anos pela Organização para a Cooperação e Desenvolvimento Econômico (OCDE). Destina-se a aferir o desempenho dos estudantes na faixa etária dos 15 anos nas áreas de Leitura, Matemática e Ciências. Seus resultados permitem equiparar os conhecimentos e as habilidades dos estudantes de diferentes países. No Brasil, O Inep é o órgão responsável pelo planejamento e a operacionalização dessa avaliação. 
condizem com uma melhoria expressiva na aprendizagem dos alunos, o que nos leva à necessidade de investigar a relação entre teoria e prática, cuja dicotomia parece ser difícil de superar.

Para tanto, parece-nos relevante saber como professores concebem a língua e seu ensino, porque pressupomos que, ao planejar, conduzir e avaliar a aprendizagem, eles põem em jogo não somente seus saberes teóricos, mas, também, suas concepções acerca língua, do aprendiz e do papel das dinâmicas interativas em sala de aula. Com base nelas, os professores fazem escolhas de conteúdo e de metodologias que implicam na transformação de "objetos de conhecimento" (culturalmente construídos) em "objeto de ensino", constituindo, assim, a transposição didática, o que, por sua vez, subsidia os processos de ensino e aprendizagem escolar. Além disso, ao se partir do pressuposto de que as interações sociais são relevantes no processo de aprendizagem da língua, é necessário compreender também o modo como os professores as promovem quando trabalham a escrita com seus alunos.

Considerando esses pressupostos, e assumindo a complexidade do processo de assimilação de princípios e propostas pedagógicas como um desafio à construção do fazer pedagógico, partimos da hipótese de que as práticas de ensino e as dinâmicas traduzidas pelos modos de interação são tributárias das concepções docentes sobre a língua, o aprendiz e o processo de ensino e aprendizagem.

Para tanto, definimos três objetivos para a presente investigação, quais sejam:

- Conhecer as concepções docentes sobre a língua e o seu ensino;

- Compreender os mecanismos de transposição didática, com base no mapeamento das situações de escrita do $1^{\circ}$ e $2^{\circ}$ anos do Ensino Fundamental (o quê, para quê, para quem e como os alunos escrevem);

- Conhecer a natureza das interações em sala de aula e suas possibilidades de contribuir para a aprendizagem, com base no mapeamento das situações de escrita do $1^{\circ}$ e $2^{\circ}$ anos do Ensino Fundamental de uma escola pública do município de São Paulo.

\subsection{Metodologia de pesquisa}

Opondo-nos a um modelo positivista de conhecimento científico, nossa pesquisa visa interpretar os eventos de língua escrita propostos em sala de aula nos dois primeiros anos do Ensino Fundamental (Ciclo de Alfabetização), especificamente, 
em termos das significações que os professores the dão, intentando superar a relação causa-efeito, bem como a dicotomia sujeito-objeto, e buscando as relações que dão sentido à práxis educativa.

Ao ponderarmos tais princípios, e com base nos objetivos gerais a que nos propusemos, optamos por uma pesquisa com abordagem qualitativa de natureza explicativa, uma vez que buscamos identificar e compreender as concepções e as condições que determinam as propostas de escrita na escola, elucidando o porquê de ocorrerem e como se qualificam no sentido de contribuir para o efetivo alfabetismo dos alunos.

Os dados quantitativos podem, eventualmente, ser levados em consideração a fim de complementar a análise qualitativa ou para favorecer a comparação entre turmas.

Para essa finalidade, decidimos realizar um Estudo de Caso em uma escola pública, cujo foco seriam as relações que se estabelecem entre os seguintes eixos de análise: as concepções docentes sobre a língua, a aprendizagem e os processos interativos que se estabelecem nas situações de ensino e aprendizagem.

Acreditamos que uma pesquisa como a pretendida é pertinente porque "pode ser representativa de casos similares". (SEVERINO, 2007, p. 121).

De modo a estar, igualmente, em consonância com Lüdke e André (1986, p. 17), pois a intenção é "estudar uma situação singular, que tenha valor em si mesma". Por isso, consideramos essencial que as características deste estudo contemplem "a obtenção de dados descritivos, obtidos numa situação natural, tenha um plano aberto e flexível e focalize a realidade de forma complexa e contextualizada" (LÜDKE; ANDRÉ, 1986, p. 18).

Pautados, ainda, nas observações da referida autora (LÜDKE; ANDRÉ, 1986), elegemos esse delineamento por entendermos que ele valoriza características que se fazem presentes no Estudo de Caso, dentre as quais, destacamos:

- A concepção de conhecimento como algo inacabado, uma vez que nossos pressupostos teóricos iniciais estarão sujeitos à descoberta de novos elementos que poderão surgir na medida em que o estudo avance;

- A necessidade de levar em consideração o contexto em que se situam os problemas a serem investigados, o que nos leva a estar atentos às ações, percepções, comportamentos e interações das pessoas envolvidas no estudo; 
- A necessidade de empreender esforços, durante a análise dos dados, para evidenciar a inter-relação dos elementos que compõem a realidade, de modo que possa ser analisada de forma completa e profunda pela explicitação da multiplicidade de dimensões, especialmente aquelas que estiverem vinculadas aos eixos de análise em questão;

- O acesso a uma variedade de fontes de informação que permita cruzar referências, confirmar ou rejeitar a hipótese, e descobrir novos dados, razão pela qual faremos uso da observação direta, de entrevistas e de um diário de campo para posterior estudo;

- A apresentação dos dados da pesquisa privilegiando uma análise relacional que favoreça a compreensão na complexidade das situações didáticas;

- A apresentação de pontos de vista conflitantes ou divergentes, caso o estudo assim os evidencie. Não pretendemos, portanto, anunciar uma verdade, e sim permitir a análise, sob diferentes perspectivas, dos problemas presentes no ensino da escrita.

\subsection{Delimitação do campo de estudo}

Com base no Programa Mais Alfabetização - criado por meio da Portaria no 142, de 22 de fevereiro de 2018, pelo Ministério da Educação, que prevê o processo de alfabetização dos estudantes regularmente matriculados no $1^{\circ}$ e no $2^{\circ}$ anos do Ensino Fundamental -, definimos como sujeitos da presente pesquisa os alunos de duas classes (uma do $1^{\circ}$ ano e uma do $2^{\circ}$ ano do Ensino Fundamental I) de uma mesma escola pública da cidade de São Paulo.

A opção por essas turmas se justifica por serem estas correspondentes ao ciclo de alfabetização previsto em lei nacional, conforme determinação dada pela Base Nacional Comum Curricular - BNCC (Resolução CNE/CP no 2, de 22 de dezembro de 2017), quando dispõe que, nos dois primeiros anos do Ensino Fundamental, a ação pedagógica deve ter como foco a alfabetização.

A escolha por duas classes de uma mesma escola visa elucidar o modo como, a partir das mesmas diretrizes educacionais e pedagógicas, o projeto de alfabetização se concretiza e como, eventualmente, modifica-se segundo as concepções docentes. 
Decidir pela escola pública (e não pela privada) é uma opção que se sustenta em duas razões, a saber: a primeira, de natureza ética, refere-se ao fato de reconhecermos como legítima a preocupação com o alfabetismo em nível nacional, uma vez que ele se constitui instrumento de inserção social e de efetivo exercício da cidadania. Daí a coerência em se examinar a alfabetização para todos na escola que é direito de todos, e que bem representa a realidade brasileira; a segunda, de ordem prática, remete à pertinência de acompanhar o compromisso assumido publicamente com o alfabetismo na idade certa e com a melhoria da qualidade do ensino, uma vez que cabe ao Estado essa responsabilidade. Nesse sentido, a opção por uma escola com desempenho dentro das metas previstas pelo IDEB também se mostrou favorável à coleta e análise dos dados, pela possibilidade de compreender, a partir de um certo patamar, as dificuldades encontradas e, a partir delas, o que ainda é passível de mudança ou de melhoria.

\subsection{Coleta de dados}

Em relação aos procedimentos de coleta de dados, pretendemos registrá-los com rigor, seguindo os princípios que caracterizam o Estudo de Caso. Por isso, temos a pretensão de permanecer no próprio ambiente escolar a ser pesquisado, observando diretamente os fenômenos que ali ocorrem, de modo a interferir o mínimo possível nas situações em sala de aula; ao imergirmos no contexto escolar, registrando e analisando as ocorrências, procuraremos identificar as relações entre elas.

Sabendo que no Estudo de Caso é importante utilizar mais de uma técnica para o levantamento dos dados, elegemos alguns procedimentos que darão suporte a esse trabalho. Dentre eles, destacamos as entrevistas com os docentes de $1^{\circ}$ e $2^{\circ}$ anos, a observação direta das situações de classe, com registro das propostas de escrita em uma tabela e em um Diário de Campo.

Vale dizer que o enfoque sobre as proposições de escrita justifica-se estritamente pelo interesse em proceder à análise documental das situações de escrita, e não pela intenção de avaliar o desempenho dos alunos, o que extrapola os objetivos do presente trabalho 
Além disso, eventualmente, as análises poderão ser complementadas por outras fontes, tal como conversas informais com as professoras de sala ou a Coordenação Pedagógica.

Estabelecemos o prazo de, aproximadamente, um mês para estarmos em cada sala de aula, a fim de garantir a coleta minimamente representativa das situações didáticas e das proposições de escrita.

Ao planejar a observação, optamos por marcar e destacar aspectos relevantes do que foi observado, fazendo anotações sempre atentas às palavras, gestos e situações manifestas de alunos e de professores.

No sentido de direcionar o foco das observações, construímos uma matriz de registro no intuito de favorecer a constituição objetiva do corpus de estudo: atividades propostas aos alunos em cada dia observado, além dos encaminhamentos práticos e das perspectivas de interação.

Quadro 8 - Observação e acompanhamento da classe do $1^{\circ}$ ano do Ensino Fundamental da Rede Pública de ensino

\begin{tabular}{|c|c|c|}
\hline \multirow{2}{*}{$\begin{array}{c}\text { Descrição da atividade no } \\
\text { contexto da aula }\end{array}$} & $\begin{array}{c}\text { Atividade de escrita / leitura / leitura e } \\
\text { escrita }\end{array}$ & \\
\hline & Frequência / duração & \\
\hline \multirow{2}{*}{ Caracterização da atividade } & O que se escreve / lê & \\
\cline { 2 - 3 } & Para que se escreve / lê & \\
\cline { 2 - 3 } Prática docente & $\begin{array}{c}\text { Para quem se escreve / lê } \\
\text { intervenções do professor }\end{array}$ & \\
\hline \multirow{2}{*}{ Dinâmica interacional } & Com o que se faz a atividade & \\
\hline & Com quem se faz a atividade & \\
\hline
\end{tabular}

Fonte: elaborado pela pesquisadora

O objetivo desse quadro é mapear, ao longo do tempo, em uma mesma classe, cada proposta didática vinculada ao ensino da língua escrita. No entanto, dado que o seu propósito é organizar o registro das informações coletadas na observação em sala de aula, não temos o compromisso de apresentá-lo preenchido nos capítulos de análise, quando os dados serão compilados em novo quadro, proposto adiante. 
Contaremos, também, com a produção de um Diário de Campo, a fim de complementar as observações da presente pesquisadora, o que the permitirá fazer descrições mais detalhadas, além de apontamentos relacionais e analíticos sobre o que não foi originalmente previsto.

Concluída a etapa de observação direta em sala de aula, realizaremos uma entrevista com o professor de cada turma, a fim de conhecer as concepções assumidas sobre a escrita e seu ensino, bem como com que critérios fundamenta sua ação em aula e quais interações julga pertinente propor aos alunos para que estes aprendam. Optamos por realizar a entrevista após a realização da observação, visando evitar que o comportamento docente em classe sofresse interferências externas em decorrência do conhecimento prévio sobre o foco de investigação desta pesquisadora.

Nossa opção por entrevistas semiestruturadas se deu porque elas permitem flexibilidade na abordagem do tema, de modo que os entrevistados possam sentir-se à vontade para discorrer a respeito das questões elaboradas, em um processo de interação mútua, com tranquilidade. O registro dos dados dar-se-á - não só, mas também - pela filmagem realizada por esta pesquisadora.

A seguir, apresentamos o roteiro básico das questões que orientarão a entrevista, incluindo também os objetivos específicos de cada questão.

Quadro 9 - Roteiro de entrevistas aos docentes

\begin{tabular}{|l|l|}
\hline \multicolumn{1}{|c|}{ Objetivos } & \multicolumn{1}{|c|}{ Perguntas aproximadas } \\
\hline $\begin{array}{l}\text { Sondar as concepções do professor sobre a } \\
\text { língua }\end{array}$ & Para você o que é a língua escrita? \\
\hline $\begin{array}{l}\text { Identificar as concepções docentes sobre o } \\
\text { processo de aprendizagem dos alunos } \\
\text { Averiguar as concepções de prática de ensino } \\
\text { da língua (transposição didática) }\end{array}$ & $\begin{array}{l}\text { De que modo a criança aprende a língua escrita? } \\
\text { Como a escrita deve ser ensinada na escola? }\end{array}$ \\
\hline $\begin{array}{l}\text { Conhecer as concepções de dinâmicas em } \\
\text { sala de aula das quais o professor lança mão } \\
\text { ao propor atividades de escrita }\end{array}$ & $\begin{array}{l}\text { Como você vê as interações (entre alunos e entre } \\
\text { alunos e o professor) e a aprendizagem da língua? }\end{array}$ \\
\hline
\end{tabular}

Fonte: elaborado pela pesquisadora 
Os dados levantados durante a entrevista com cada professor serão organizados em um quadro-síntese, no qual será feita a compilação das ideias centrais de suas respostas; nesse processo, recorremos a Bardin (1977) ${ }^{22}$, cujos estudos sobre a organização dos conteúdos permite a análise de significados:

A análise de conteúdo aparece como um conjunto de técnicas de análise das comunicações, que utiliza procedimentos sistemáticos e objetivos de descrição do conteúdo das mensagens. Mas isso não é suficiente para definir a especificidade da análise do conteúdo [...].

[...] o interesse não reside [só] na descrição dos conteúdos, mas sim no que estes nos poderão ensinar após serem tratados (por classificação, por exemplo) relativamente a "outras coisas".

A intenção da análise de conteúdo é a inferência de conhecimentos relativos às condições de produção (ou eventualmente, de recepção), inferência essa que recorre a indicadores (quantitativos ou não). (BARDIN, 1977, p. 38, grifos do autor)

Para tanto, buscaremos sintetizar, da maneira mais fiel possível, o que foi dito pelos professores, a fim de garantir com precisão os núcleos de significado de suas respectivas ideias, as quais serão registradas em um quadro, tal como o Quadro 10, a seguir.

Quadro 10 - Síntese da entrevista realizada com os professores

\begin{tabular}{|c|c|c|c|}
\hline \multicolumn{4}{|c|}{ 10 Ano } \\
\hline Língua & Aprendizagem & Ensino & Interação \\
\hline $\begin{array}{l}\text { Para você o que } \\
\text { é a língua } \\
\text { escrita? }\end{array}$ & $\begin{array}{l}\text { De que modo a } \\
\text { criança aprende a } \\
\text { língua escrita? }\end{array}$ & $\begin{array}{lr}\text { Como a } & \text { escrita } \\
\text { deve } & \text { ser } \\
\text { ensinada } & \text { na } \\
\text { escola? } & \end{array}$ & $\begin{array}{l}\text { Como você vê as interações } \\
\text { (entre alunos ou entre alunos e } \\
\text { o professor) e a aprendizagem } \\
\text { da língua? }\end{array}$ \\
\hline
\end{tabular}

Fonte: elaborado pela pesquisadora

\subsection{Análise de dados}

A análise dos dados obtidos será prioritariamente qualitativa e buscará conhecer a relação existente entre os conceitos dos professores a respeito da escrita na escola, a prática proposta em sala de aula, as dinâmicas interacionais e os processos de aprendizagem dos alunos.

Levaremos em consideração os fatores que condicionam suas escolhas ao optar por um ou por outro tipo de produção escrita, bem como o momento de propô-

\footnotetext{
${ }^{22} \mathrm{Na}$ presente pesquisa, sem a pretensão de seguir detalhadamente todas as diretrizes de análise de conteúdo propostas por Bardin (1977), valemo-nos do princípio por ele postulado para captar o núcleo básico das concepções das docentes entrevistadas.
} 
las e o modo de fazê-lo, além da previsão das interações necessárias à sua realização.

No intuito de analisar os dados levantados, estabeleceremos confronto entre as dimensões discursiva e da prática pedagógica: no âmbito discursivo, identificaremos as referências conceituais que subsidiam a prática docente, focalizando, como eixos de análise, as concepções docentes sobre a natureza da língua escrita e seu ensino, sobre o processo de aprendizagem dos alunos e o papel das interações na aprendizagem; no âmbito da prática pedagógica, os mesmos eixos de análise serão considerados, no entanto, o propósito aqui será analisar e comparar as propostas didáticas de escrita em duas classes de alfabetização.

Desse modo, pretende-se identificar pontos de observação que permitam mapear as práticas docentes sobre a escrita, os modos de ensino e as interações que decorrem das proposições realizadas aos alunos.

A seguir, há o Quadro 11, quadro-síntese que nos orientará nesse processo. 
Quadro 11 - Eixos e âmbitos de análise

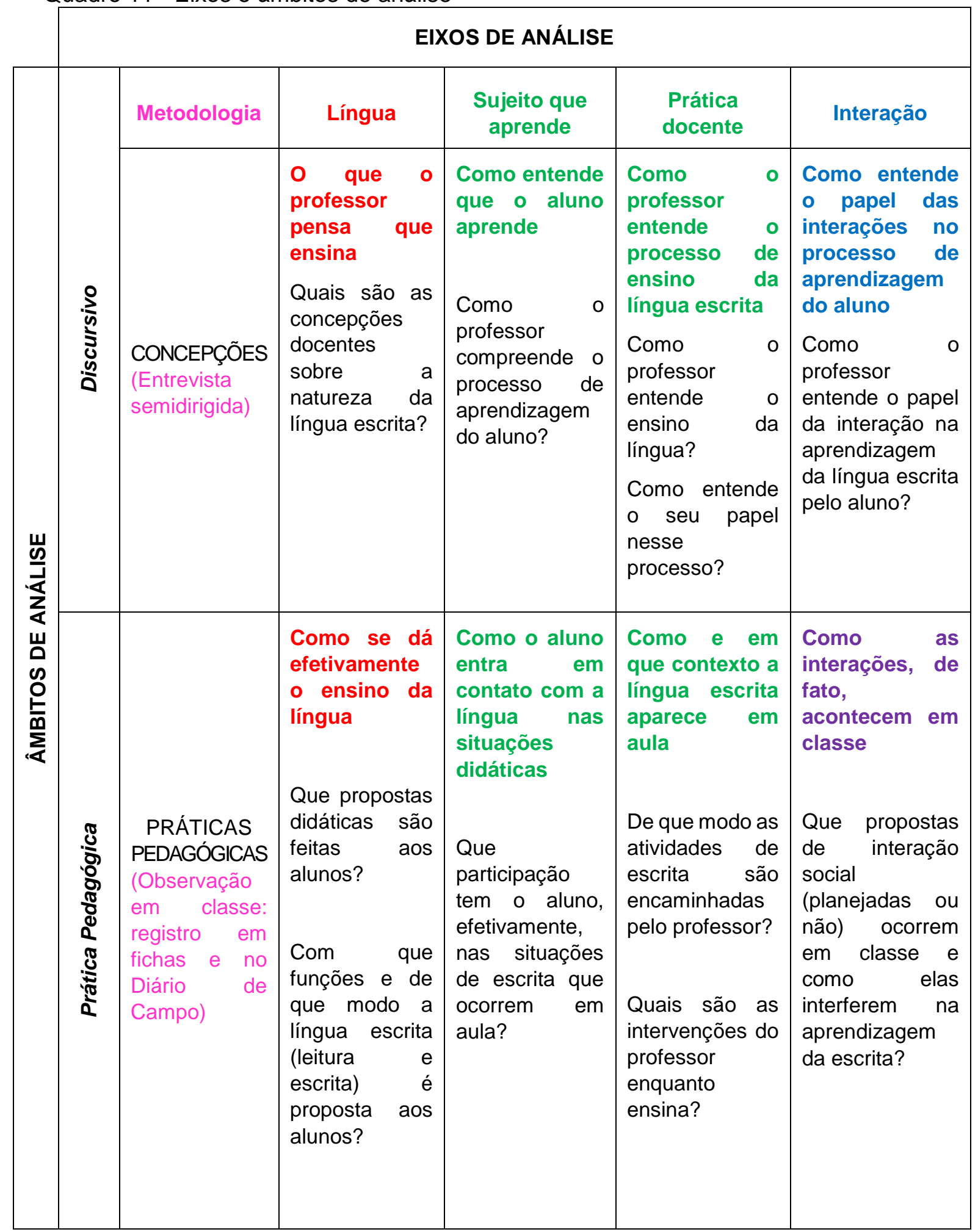

Fonte: elaborado pela pesquisadora

A fim de proceder à síntese dos dados coletados durante a observação em sala de aula, organizaremos um quadro elaborado para cada grupo-classe observado; seu objetivo será o de mapear as propostas de ensino realizadas nas aulas de Língua Portuguesa, perpassando os diferentes âmbitos e eixos de investigação. 
Quadro 12 - Síntese de dados coletados durante observação em sala

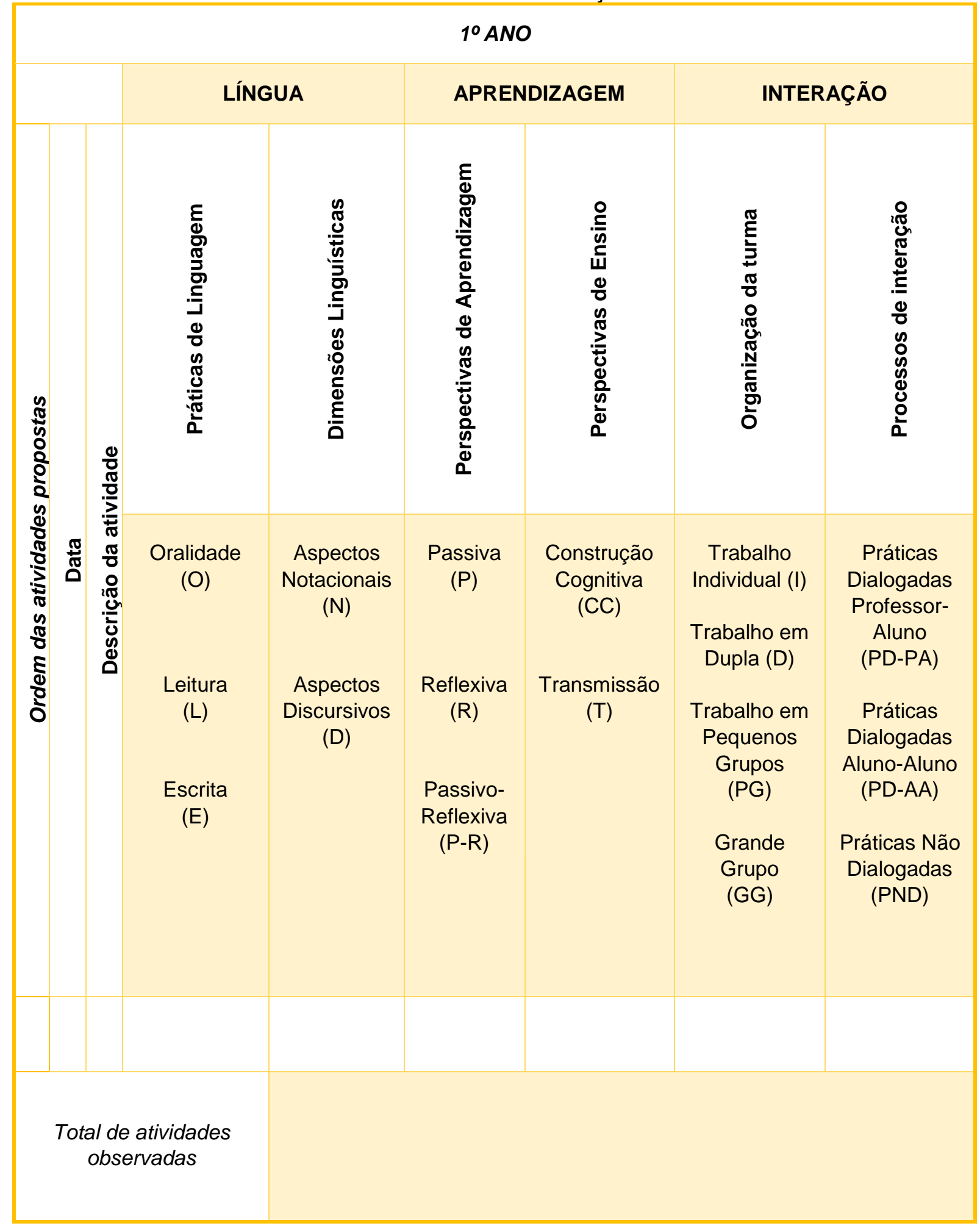

Fonte: elaborado pela pesquisadora

Vale mencionar que cada um dos aspectos apresentados no quadro acima será melhor especificado no oitavo capítulo deste estudo, quando explicitaremos o percurso de análise a que nos dedicamos. 


\section{CONTEXTO DA PESQUISA}

Este capítulo pretende apresentar a escola que foi campo de estudo, descrevendo-a em sua estrutura física e na organização do tempo e organização dos espaços escolares. Trata também de situá-la no cenário de avaliações oficiais do Sistema de Educação Básica e frente ao Currículo da Cidade, marco referencial da rede municipal de ensino de São Paulo.

\subsection{O bairro}

A presente pesquisa foi realizada junto a professores e alunos da EMEF Marechal Espiridião Rosas, escola da rede municipal de ensino de São Paulo que está situada na Vila Lajeado, bairro localizado no distrito do Jaguaré, zona oeste da cidade.

Com uma área de aproximadamente $6,6 \mathrm{~km}^{2}$ e uma população de 42,4 mil habitantes, de classe média, em sua maioria, o Jaguaré está subordinado à subprefeitura da Lapa e faz limite com os bairros Vila Leopoldina, Alto de Pinheiros, Butantã e Rio Pequeno, e com a zona centro-sul do município de Osasco. O mapa a seguir situa a localização do bairro.

Figura 1 - Mapa do bairro Jaguaré, zona oeste da cidade de São Paulo

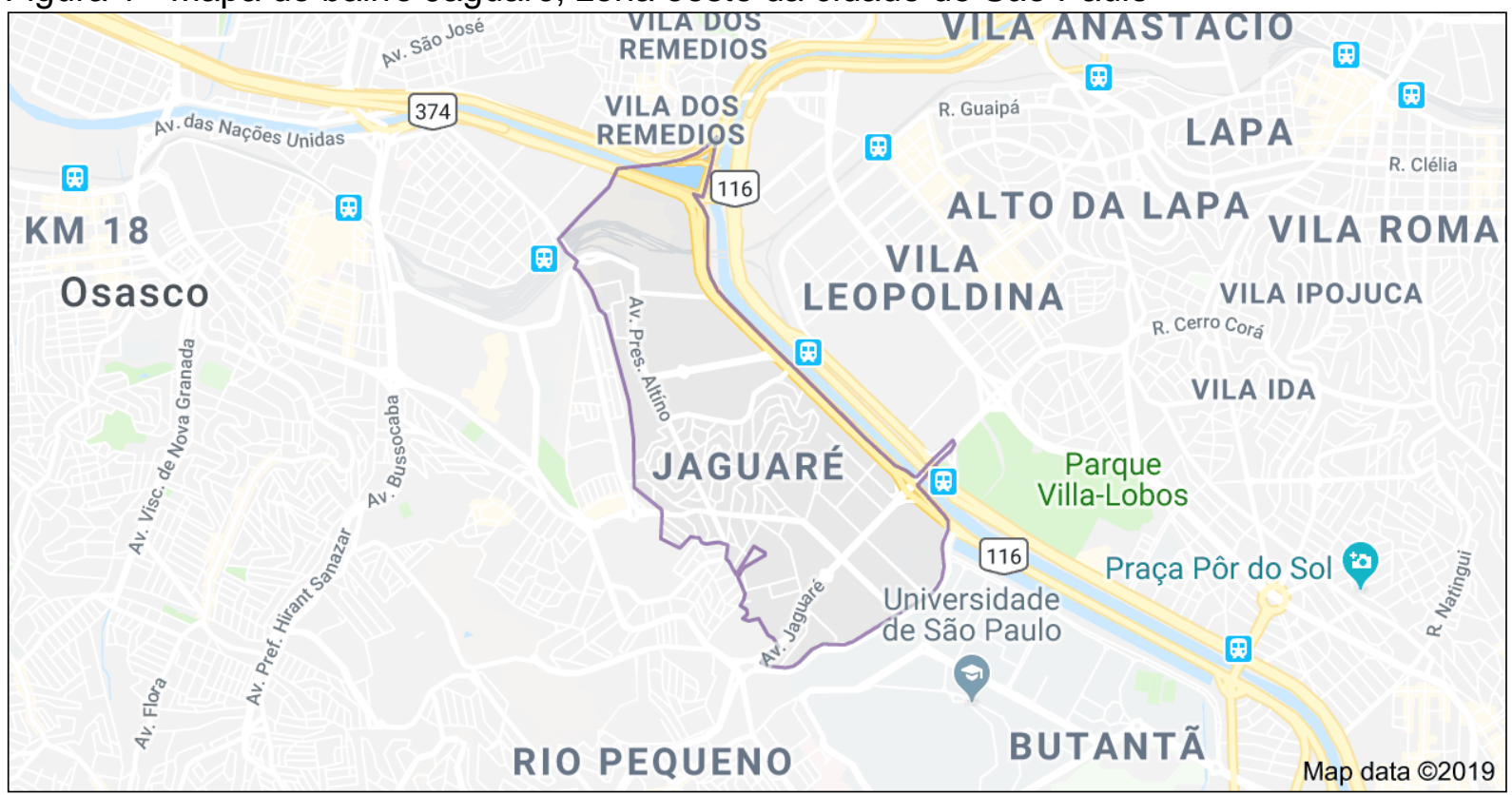

Fonte: Google Maps (2019). ${ }^{23}$

${ }^{23}$ GOOGLE MAPS. 2019. Disponível em: https://www.google.com.br/maps/place/Jaguar\%C3\%A9,+ S\%C3\%A30+Paulo+-+SP. Acesso em: 10 jul. 2019. 
Na região, predominam casas térreas, sobrados e prédios antigos; no entanto, nos últimos anos, investimentos no setor imobiliário têm incentivado a verticalização das áreas residenciais, com diversas construções de alto padrão.

Apesar disso, encontram-se aí grandes comunidades, tais como a do Areião, que faz divisa com o município de Osasco, e a Vila Nova Jaguaré, situada às margens do Rio Pinheiros; esta é a maior comunidade da cidade em área contínua, atualmente com 12 mil habitantes e em fase de reurbanização pela Prefeitura. Encontra-se também, nesse bairro, a comunidade São Remo, próxima ao campus da cidade universitária.

O bairro, com boa infraestrutura, possui diversidade de indústrias e de comércio, permitindo fácil acesso a supermercados, redes varejistas e shopping centers, além de escolas, hospitais, praças e parques públicos.

No entorno da referida escola há diversas residências, que convivem com o forte comércio local; por estarem próximas a uma extensa avenida da região, há muito tráfego de veículos automotivos e de pedestres, o que torna a área bastante movimentada a qualquer hora do dia.

Ao lado da escola, há um mini balneário público, com piscinas e quadras poliesportivas destinadas à comunidade. No mais, são poucos os espaços comunitários de lazer existentes nas imediações, bem como ambientes culturais e de entretenimento; clubes, bibliotecas e praças encontram-se a uma distância de até 6 $\mathrm{km}$, aproximadamente. 


\subsection{A escola}

\subsubsection{Aspectos gerais}

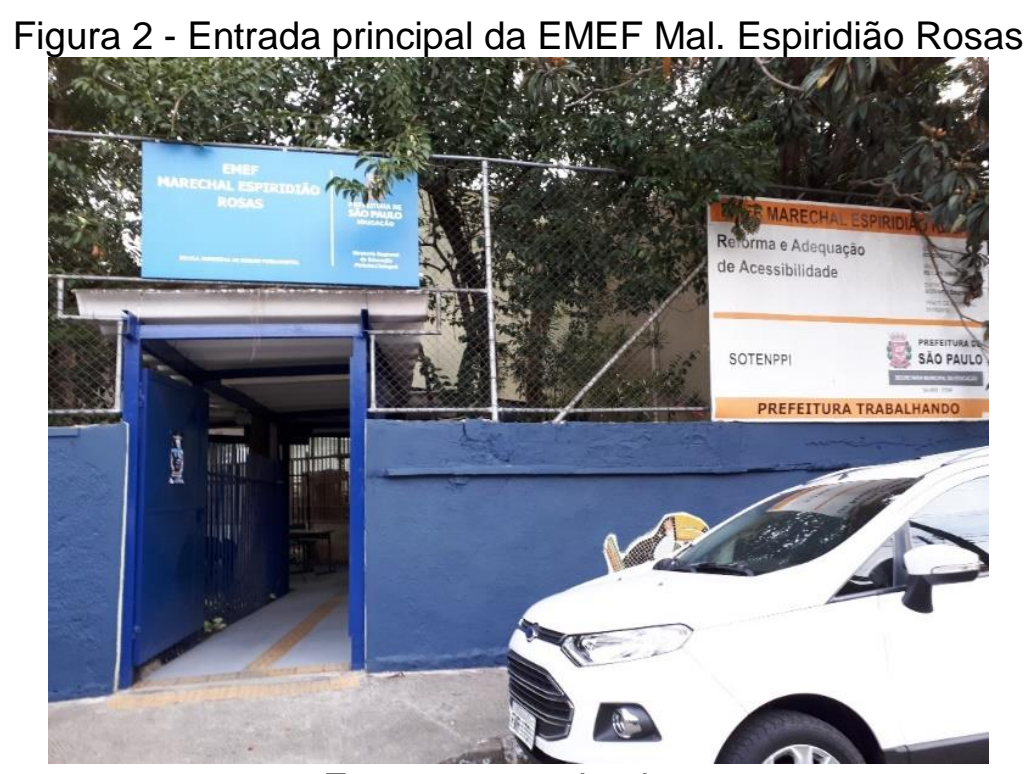

Fonte: a pesquisadora.

Fundada por meio do Decreto № 3.341, de 16 de novembro de 1956, a então "Escola Isolada da Vila Operária" iniciou seu funcionamento em um pequeno galpão, sendo posteriormente ampliada. Por força de novo decreto, (o de ㄲo 7.152, de 25 de agosto de 1976), passou a ser denominada Escola Municipal Marechal Espiridião Rosas e, somente a partir de 27 de janeiro de 1999 (em razão do Decreto № 37.796, o qual determinou que todas as escolas municipais fossem denominadas Escola Municipal de Ensino Fundamental - EMEF), passou a ser nomeada Escola Municipal de Ensino Fundamental Espiridião Rosas.

Atualmente pertence à Secretaria Municipal de Educação de São Paulo (SME$\mathrm{SP}$ ), vinculada à Diretoria Regional de Educação (DRE) Pirituba-Jaguaré. Atende aos segmentos de Ensino Fundamental I e II na modalidade regular; também existe 0 curso de Educação de Jovens e Adultos (EJA), correspondente ao Ensino Fundamental regular, organizado em etapas semestrais, cada uma equivalendo a um ano escolar.

Funcionando em três turnos, o ensino regular recebe 885 alunos do $5^{\circ}$ ao $9^{\circ}$ anos no período matutino ( $7 \mathrm{~h}$ às $11 \mathrm{~h} 50)$; o período da tarde (13h30 às $18 \mathrm{~h} 20)$ atende 384 alunos, distribuídos entre $\circ 1^{\circ}$ e $\circ 5^{\circ}$ anos, estando 270 deles no Ciclo de 
Alfabetização; o período da noite (19h às 22h50) destina-se a 239 alunos do EJA (duas turmas de EF1 e 5 turmas de EF2).

A escola atende prioritariamente às comunidades Vila Nova Jaguaré, Areião e São Remo, além dos residentes na Vila Yara e Rio Pequeno. No total, são 1508 alunos, que advêm de diferentes níveis socioeconômicos: $70 \%$ deles são pessoas em estado de vulnerabilidade econômica e social.

Há três anos, aproximadamente, dada a crise econômica no país, tem sido significativa a chegada de alunos com melhores condições sociais (30\% aproximadamente), os quais são provenientes de escolas particulares, tendo migrado para a escola pública por questões financeiras. A escola aponta esse dado como relevante, pois trata-se do ingresso de alunos com um novo perfil, cujas famílias, geralmente, mostram-se mais críticas, atentas e acompanham proximamente a escolaridade dos filhos: é comum não aceitarem quaisquer propostas da escola sem saber ao certo de que se trata, bem como cobrarem a ausência de professores, pois se preocupam com o prejuízo educacional de seus filhos e têm interesse em conhecer o projeto pedagógico.

A escola observa que as famílias menos favorecidas economicamente, muitas vezes, têm a expectativa de ter seus filhos na escola por motivos outros que não a aprendizagem dos alunos; uma das razões refere-se ao interesse pela merenda escolar, que inclui almoço e lanche. Igualmente, não é raro observar que os benefícios decorrentes do Programa Leve Leite ${ }^{24}$ e do transporte escolar (oferecido a quem reside a mais de $2 \mathrm{~km}$ da unidade escolar) sejam prioridade para esse grupo, haja vista que ambos são muito solicitados pelas famílias.

Há pais, ainda, que matriculam seus filhos apenas em virtude da exigência legal, pois temem represálias do Conselho Tutelar, já que cursar o Ensino Fundamental é obrigatório. De todo modo, o cumprimento da lei não reverbera, necessariamente, na participação efetiva do aluno, tampouco de sua família, nos processos de ensino e aprendizagem.

Também se observa uma diferença significativa entre os alunos provenientes das Escolas Municipais de Educação Infantil (EMEls) e das escolas privadas de

24 O Programa Leve Leite é uma iniciativa governamental normatizada pelo Decreto Municipal no 57.632/2017, que prevê a entrega de leite em pó integral às crianças em idade de creche e préescola, matriculadas na Rede Municipal de Ensino de São Paulo, residentes na cidade de São Paulo. Também têm direito ao benefício os alunos com deficiências a partir de 1 (um) ano de idade até a conclusão do 5o ano do Ensino Fundamental. 
Educação Infantil. Em geral, ao chegar ao primeiro ano do Ciclo de Alfabetização, as crianças oriundas da rede privada já apresentam algum conhecimento sobre a língua escrita (escrevem o próprio nome, conhecem as letras e não confundem letras e outros grafismos), enquanto aquelas advindas da rede pública, em geral, desconhecem o universo da escrita.

A maioria dos alunos que ingressam no primeiro ano do Ensino Fundamental I é proveniente de escolas de Educação Infantil da própria rede municipal (EMEls), e cerca de $90 \%$ deles segue sua escolaridade na própria EMEF. São poucos os alunos que nunca frequentaram anteriormente uma escola, o que ocorre, em geral, com aqueles que vêm de outros estados do país.

Na realização da presente pesquisa, foram acompanhados alunos em processo de alfabetização, particularmente os que frequentam o primeiro e o segundo anos do Ensino Fundamental I. Nesse segmento, há pouca distorção entre idade/série e, em média, cada turma é composta por 25 a 30 alunos.

\subsubsection{A organização do espaço e do tempo escolares}

A escola dispõe das seguintes dependências, distribuídas em dois pavimentos: 14 salas de aula, laboratório de informática, sala de leitura, quadra poliesportiva coberta, quadra de esportes descoberta e um pátio coberto, refeitório, parque infantil, sala de recursos multifuncionais para Atendimento Educacional Especializado (AEE), cozinha, despensa e almoxarifado, banheiros no interior do prédio, banheiro e dependências adequadas a pessoas portadoras de deficiência ou com mobilidade reduzida. Oferece alimentação aos alunos em todos os turnos e disponibiliza acesso à internet. As fotos a seguir ilustram alguns desses ambientes supracitados ${ }^{25}$.

25 Todas as fotos da escola e de atividades analisas que constam nesta pesquisa são de autoria da própria pesquisadora. 
Figura 3 - Quadra de esportes coberta

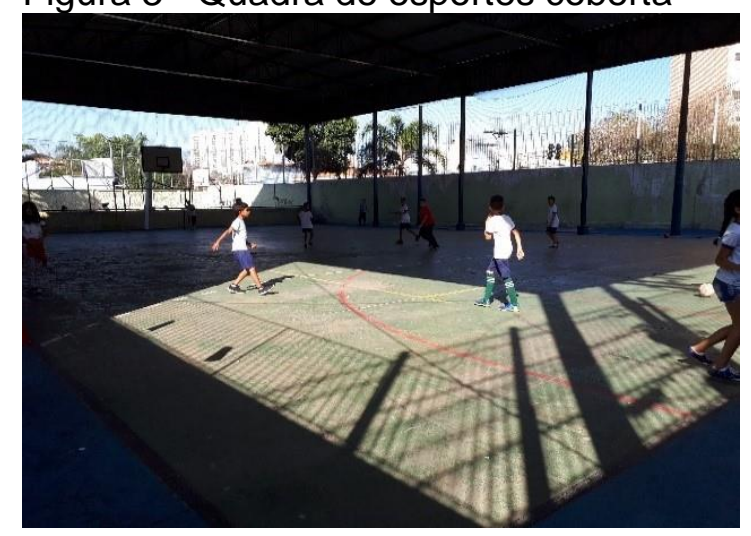

Figura 5 - Parque infantil

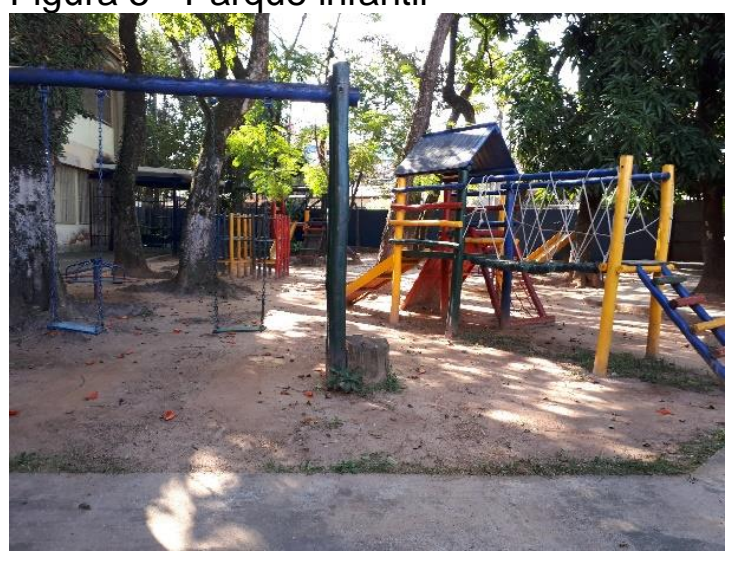

Figura 7 - Salas de aula

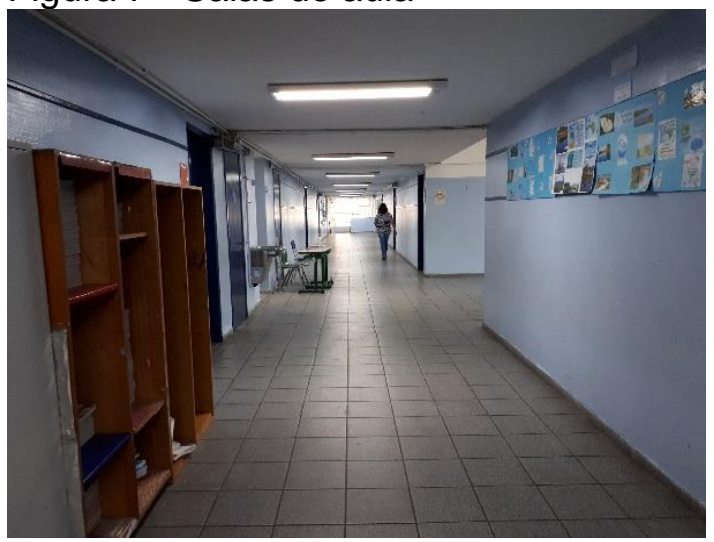

Figura 4 - Pátio coberto

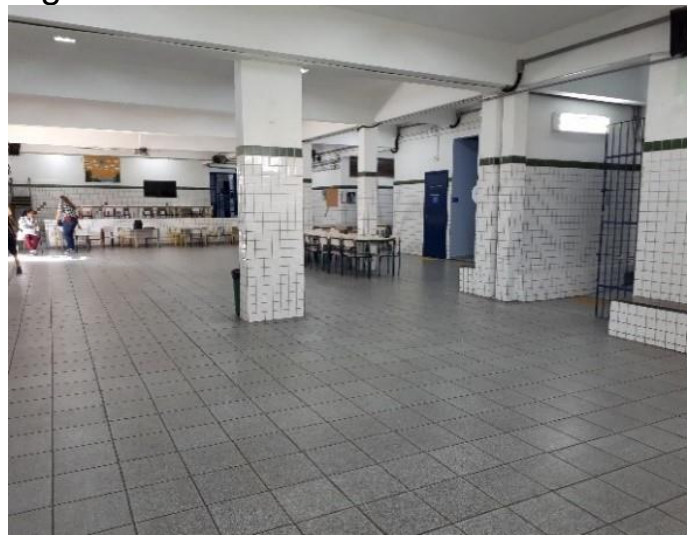

Figura 6 - Pátio descoberto

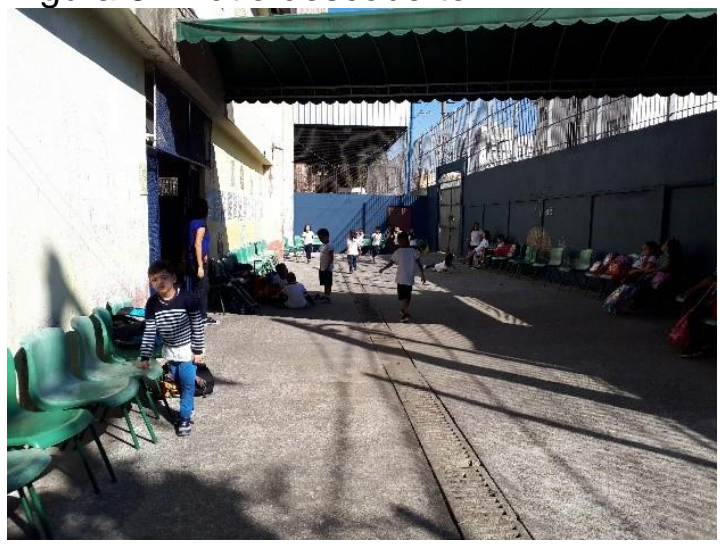

Figura 8 - Refeitório

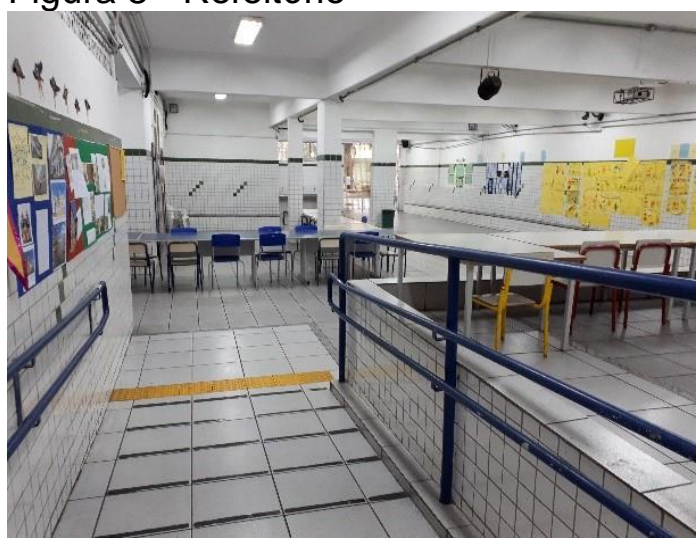


Figura 9 - Laboratório de Informática

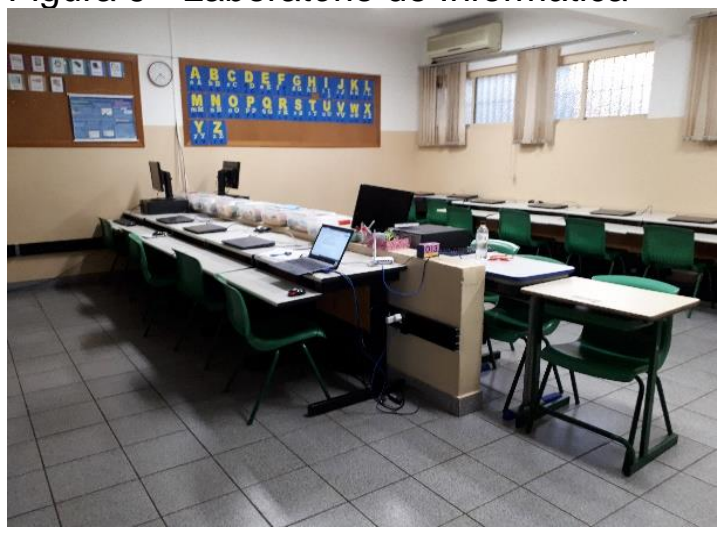

Figura 10 - Sala de leitura

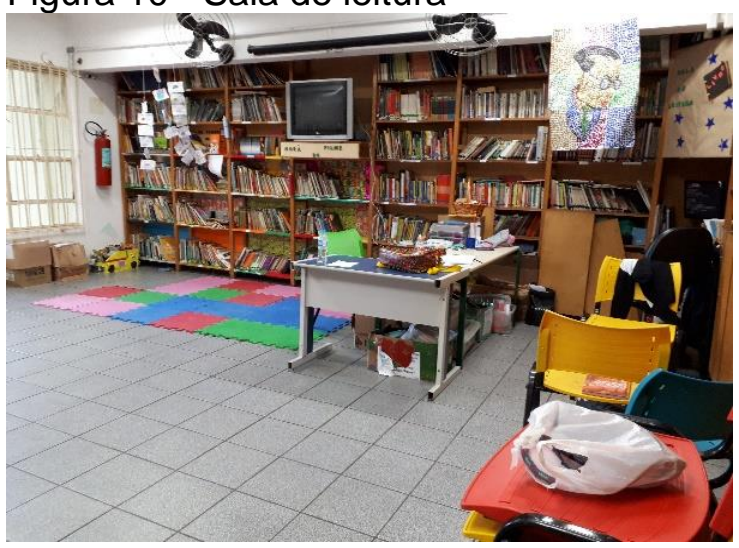

O tempo de trabalho pedagógico está organizado em horas-aula de 45 minutos, sendo 25 delas destinadas ao professor de sala, que as divide na grade semanal com as aulas especializadas: Inglês (1 por semana); Educação Física (2 por semana); Artes (1 por semana); Informática (1 por semana); e Sala de Leitura (1 por semana). No caso destas duas últimas, o docente responsável, licenciado em Letras, deve ser funcionário efetivo da rede e apresentar um projeto de trabalho ao Conselho de Escola, que o elege mediante apresentação e endosso da comunidade, a fim de que possa atuar na Sala de Leitura.

É previsto que o trabalho nessas aulas esteja integrado com o que ocorre em sala de aula. No entanto, segundo a Coordenação Pedagógica, não é o que predominantemente se verifica: chega a haver ações que aproximam o trabalho de classe com o das aulas de Leitura e de Informática, mas isso depende muito do perfil e da disponibilidade dos professores, tanto dos de classe, quanto dos especialistas.

\subsubsection{Equipe técnico-pedagógica}

O quadro laboral da escola é composto por 78 funcionários, que atuam em diferentes funções; dele, fazem parte os professores, o diretor, os assistentes de direção, os coordenadores pedagógicos, os ATEs (Auxiliares Técnicos, conhecidos por "inspetores de alunos") e os secretários. As equipes que preparam a merenda escolar e os agentes de manutenção e de limpeza são funcionários terceirizados.

A carga horária docente é definida por ocasião das atribuições de aula, momento em que o professor faz sua opção de jornada de trabalho, a qual pode enquadrar-se em duas modalidades: sob o formato de Jornada Básica Docente (JBD), em que cabe ao professor cumprir 30 horas-aula semanais, sendo 25 horas-aula 
destinadas à regência, 3 horas de trabalho individual na escola e 2 horas destinadas ao trabalho dentro ou fora da unidade escolar; sob o formato de Jornada Especial Integral de Formação (JEIF), em que a carga horária docente é maior. Ao optar por essa modalidade, caberá ao professor, além de trabalhar 25 horas-aula na regência, complementar sua jornada com 8 horas-aula de estudo junto à Coordenação Pedagógica, 3 horas de trabalho individual na escola e mais 2 horas-aula destinadas ao trabalho dentro ou fora da unidade escolar.

Dentre suas diversas atribuições, cabe à Coordenação Pedagógica acompanhar o trabalho docente, bem como o aproveitamento dos alunos, orientando ações que possam promover avanços qualitativos nas instâncias de ensino e de aprendizagem. Com essa finalidade, deve oferecer orientações didáticas, acompanhar planejamentos e promover situações formais de estudo, especialmente nas reuniões de JEIF, quando a equipe docente se reúne para articular teoria e prática por meio da reflexão sobre a ação educativa.

$\mathrm{Na}$ escola observada, a maioria dos professores do Ensino Fundamental faz parte da JEIF. No entanto, como há um grupo de professores que não optaram por esse tipo de jornada, uma dificuldade se impõe: não há como garantir que todos os professores da escola possam partilhar e caminhar na direção das mesmas diretrizes pedagógicas previstas no Projeto Político Pedagógico da escola. Com estes docentes, o coordenador pedagógico se comunica por e-mail, na tentativa de deixá-los minimamente a par do que é discutido nas reuniões de JEIF; contudo, tem ciência de que essa medida apenas ameniza o problema, mas não vê outra possibilidade, em vista da falta de tempo. Há, também, casos em que os professores o procuram para saber acerca do que foi discutido e acordado, mas trata-se de uma ação que nem sempre garante que haja mudanças na prática dos professores junto aos alunos.

No máximo, o número de matrículas é de 30 estudantes por classe, sendo a regência conferida a um professor polivalente. Além disso, com base na Portaria $\mathrm{n}$ ำ 1.336, de 19 de fevereiro de 2015, a Secretaria Municipal de Educação criou o programa "Parceiros da Aprendizagem", cujo objetivo é apoiar o professor regente do $1^{\circ}$ ano do Ciclo de Alfabetização. Esse programa, associado ao Centro de Integração Empresa Escola (CIEE), prevê a contratação de alunos de licenciatura (preferencialmente do curso de Pedagogia, sendo aceitos também alunos matriculados em cursos de Letras e de Matemática) como professores estagiários, os quais permanecem como auxiliares apenas nas classes de primeiro ano. 
A escola, que permanece fechada aos finais de semana para atividades extraescolares, parece ter boa relação com a comunidade, que é esporadicamente convidada a participar da vida escolar, em eventos como a Festa Junina e a Mostra Cultural. Também são promovidas atividades pontuais, que envolvem as famílias e a comunidade, por meio da participação direta dos alunos (o que se dá em estudos do meio, viagens, acampamentos e festas de encerramento), e das reuniões de pais, em geral, com baixa adesão e presença.

Com vistas a garantir uma gestão democrática, a escola conta com pais, professores e funcionários que constituem a APM (Associação de Pais e Mestres) e os Conselhos de Escola (do qual participam também os alunos). Tais instâncias promovem regularmente reuniões para prestar contas à sociedade e deliberarem sobre demandas e prioridades específicas da comunidade, considerando, inclusive, as verbas disponíveis.

Apesar de haver um número representativo de famílias engajadas nessas atribuições, a escola avalia que ainda são poucos os que assumem o compromisso de participar do gerenciamento coletivo da unidade escolar, e, portanto, almeja que a participação da sociedade se torne cada vez mais efetiva.

\subsubsection{A escola no cenário dos sistemas de avaliação}

Com o intuito de monitorar as conquistas progressivas de melhoria na qualidade da educação básica, prevista no Plano de Desenvolvimento da Educação (PDE), destaca-se aqui o Índice de Desenvolvimento da Educação Básica (IDEB), criado em 2007 pelo Instituto Nacional de Estudos e Pesquisas Educacionais Anísio Teixeira (INEP). Formulado para medir a qualidade do aprendizado nacional, constitui um importante condutor de políticas públicas e permite que a sociedade se mobilize na busca de melhorias no ensino.

O IDEB é calculado a partir dos dados sobre aprovação obtidos no Censo Escolar e das médias de desempenho dos estudantes nas avaliações do INEP, o Sistema de Avaliação da Educação Básica (SAEB) - no caso das unidades da federação e para o país -, e a Prova Brasil - para os municípios.

O Censo escolar, realizado anualmente, considera vários fatores, dentre os quais, destacam-se: o desempenho dos alunos nas provas de Língua Portuguesa e de Matemática; os índices de reprovação; e a distorção entre idade/série. 
As avaliações do SAEB e da Prova Brasil são realizadas a cada dois anos, e dela participam os alunos das séries finais de cada segmento, ou seja, os do $5^{\circ}$ e $9^{\circ}$ anos do Ensino Fundamental e os do 3ํano do Ensino Médio.

Para acompanhar as metas de qualidade da educação nacional, o índice IDEB varia de 0 a 10 (zero a dez). Embora haja metas diferenciadas para cada escola e rede de ensino, o Plano de Desenvolvimento da Educação (PDE) estabelece como meta nacional, para 2022, um IDEB de nível 6,0, por entender que esta é uma média que corresponde a um sistema educacional de mais qualidade.

Conforme a Tabela 2, a seguir, a escola-campo em que se dá a presente pesquisa, encontra-se dentro das metas previstas do IDEB, o que, segundo a coordenação pedagógica, deixa a equipe educativa em posição confortável frente à média nacional esperada.

Tabela 2 - Índices de aprovação IDEB/SAEB - EMEF Espiridião Rosas Anos iniciais do ensino fundamental

\begin{tabular}{|c|c|c|c|c|c|c|c|c|c|c|c|}
\hline \multirow[b]{3}{*}{ Ano } & \multicolumn{6}{|c|}{ Taxa de Aprovação } & \multicolumn{5}{|c|}{ Saeb } \\
\hline & \multirow[b]{2}{*}{$1^{\circ}$} & \multirow[b]{2}{*}{$2^{\circ}$} & \multirow[b]{2}{*}{$3^{\circ}$} & \multirow[b]{2}{*}{$4^{0}$} & \multirow[b]{2}{*}{$5^{\circ}$} & \multirow[b]{2}{*}{$\begin{array}{l}\mathrm{P} \\
\text { (i }\end{array}$} & \multicolumn{2}{|c|}{ Matemática } & \multicolumn{2}{|c|}{ Língua Portuguesa } & \multirow[b]{2}{*}{${ }^{\mathrm{N}}$} \\
\hline & & & & & & & $\begin{array}{l}\text { Proficiência } \\
\text { Média }\end{array}$ & $\begin{array}{l}\text { Proficiência } \\
\text { Padronizada }\end{array}$ & $\begin{array}{c}\text { Proficiência } \\
\text { Média }\end{array}$ & $\begin{array}{l}\text { Proficiência } \\
\text { Padronizada }\end{array}$ & \\
\hline 2005 & - & 99,0 & 100,0 & 100,0 & 90,6 & 0,97 & 167,6 & 4,1 & 167,9 & 4,3 & 4,22 \\
\hline 2007 & - & 97,7 & 95,7 & 99,0 & 83,5 & 0,94 & 191,3 & 5,0 & 171,6 & 4,5 & 4,73 \\
\hline 2009 & - & 100,0 & 94,3 & 100,0 & 90,0 & 0,96 & 189,1 & 4,9 & 168,3 & 4,3 & 4,63 \\
\hline 2011 & 100,0 & 100,0 & - & 100,0 & 77,5 & 0,93 & 199,2 & 5,3 & 179,7 & 4,8 & 5,03 \\
\hline 2013 & 100,0 & 100,0 & 100,0 & 100,0 & 94,4 & 0,99 & - & -- & - & - & - \\
\hline 2015 & 98,0 & 97,0 & 84,6 & 98,3 & 95,0 & 0,94 & 215,9 & 6,0 & 207,9 & 5,8 & 5,86 \\
\hline 2017 & 94,9 & 97,7 & 81,4 & 98,5 & 95,8 & 0,93 & 226,2 & 6,3 & 212,0 & 5,9 & 6,13 \\
\hline
\end{tabular}

Fonte: IDEB (2017) 
Tabela 3 - Meta e valor de referência EMEF Espiridião Rosas
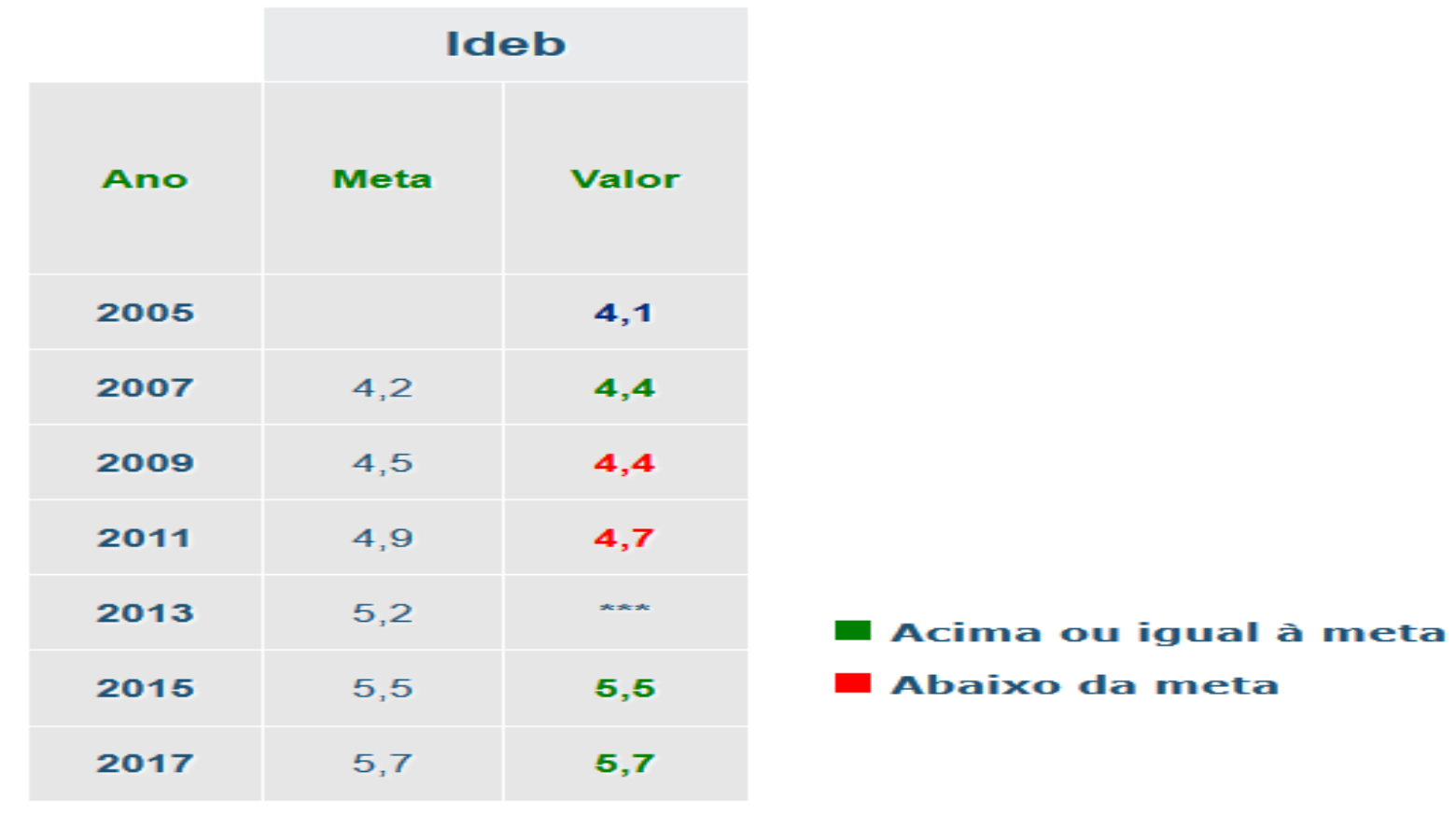

Fonte: IDEB (2005-2017)

Outra ferramenta de avaliação para diagnóstico em larga escala da educação é a Prova Brasil. Constituída por testes destinados aos alunos que concluem o 5ํ e o 9o anos do Ensino Fundamental, a prova é aplicada a cada dois anos, quando os estudantes respondem a questões de Língua Portuguesa, com foco em leitura, e de Matemática, com foco na resolução de problemas.

A seguir, no Gráfico 4, os resultados da escola-campo, avaliada nos anos 2015 (86\% dos alunos do 5o ano participaram) e 2017 (82\% dos alunos do 5o ano participaram).

Gráfico 4 - Prova Brasil - 2015

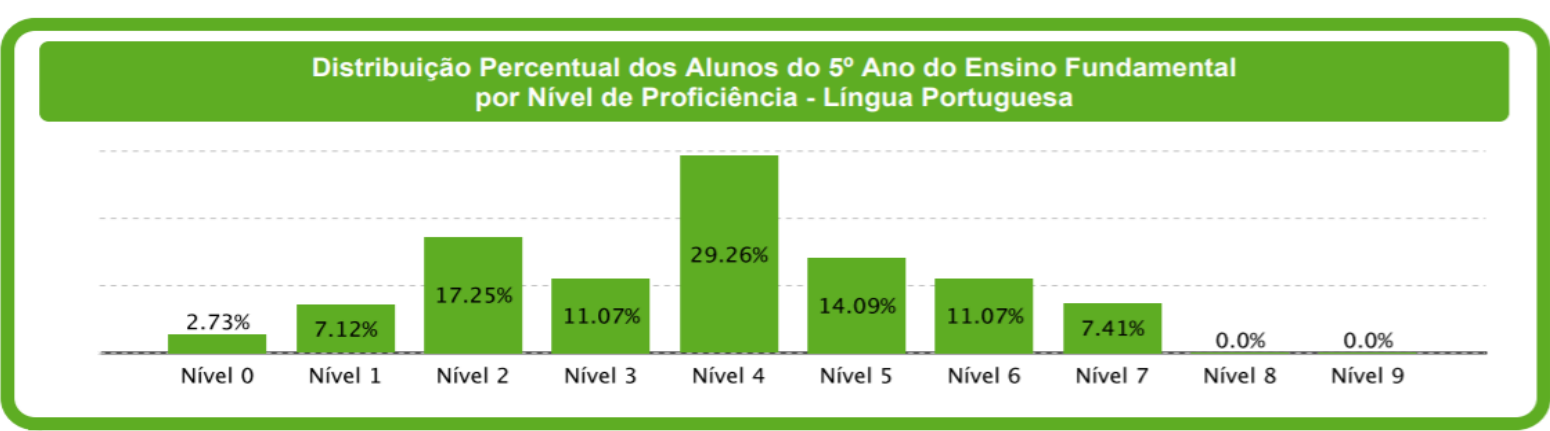

Fonte: INEP (2015) 
Gráfico 5 - Prova Brasil - 2017

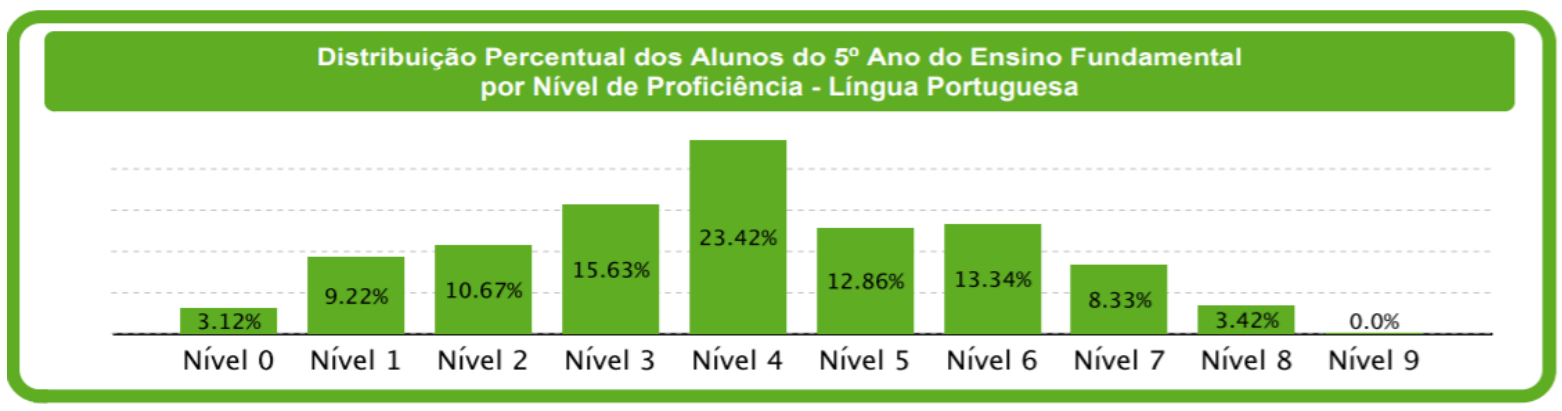

Fonte: INEP (2017)

Por meio dos dados apresentados, observa-se que, tanto em 2015, quanto em 2017, a maioria dos alunos revelou proficiência no domínio da leitura, situando-se no nível 4, o que significa que esses estudantes, provavelmente, são capazes de:

\begin{abstract}
Identificar informação explícita em sinopses e receitas culinárias. Identificar assunto principal e personagem em contos e letras de música. Identificar formas de representação de medida de tempo em reportagens. Identificar assuntos comuns a duas reportagens. Identificar o efeito de humor em piadas. Reconhecer sentido de expressão, elementos da narrativa e opinião em reportagens, contos e poemas. Reconhecer relação de causa e consequência e relação entre pronomes e seus referentes em fábulas, poemas, contos e tirinhas, e inferir sentido decorrente da utilização de sinais de pontuação e sentido de expressões em poemas, fábulas e contos. Inferir efeito de humor em tirinhas e histórias em quadrinhos. (INEP, $2015^{26}$ )
\end{abstract}

Além das avaliações oficiais de larga escala promovidas pelo INEP, a escola pesquisada acompanha a aprendizagem de seus alunos por meio de avaliações internas e busca desenvolver estudos e ações no sentido de promover a melhoria da qualidade da educação básica, especialmente no que se refere à aprendizagem da leitura, da escrita e do conhecimento matemático.

A seguir, na Tabela 4, constam os resultados das avaliações de Língua Portuguesa que ocorreram nas classes estudadas. $O$ resultado das provas aplicadas no final do quarto bimestre de 2018 serviram para subsidiar a definição das metas para compor o Projeto Político Pedagógico da escola em 2019.

${ }^{26}$ Disponível em: http://download.inep.gov.br/educacao_basica/prova_brasil_saeb/escala/escala_ proficiência/2018/LP_5EF.pdf. Acesso em: 23 jul. 2019. 
Tabela 4 - Aproveitamento Escolar em Língua Portuguesa- 4ํㅡㄹ bimestre 2018

\begin{tabular}{|c|c|c|c|c|}
\hline & & Plenamente Satisfatório & Satisfatório & Não Satisfatório \\
\hline $\mathbf{1}^{\circ}$ ano & 29 alunos & $42 \%$ & $54 \%$ & $4 \%$ \\
\hline $\mathbf{2}^{\mathbf{0}}$ ano & 28 alunos & $48 \%$ & $41 \%$ & $11 \%$ \\
\hline
\end{tabular}

Fonte: Projeto Político Pedagógico (PPP, 2019) da EMEF Espiridião Rosas

No que diz respeito aos alunos com dificuldade ou defasagem de aprendizagem, estes são encaminhados ao Programa de Recuperação Paralela, que se dá no contraturno das atividades regulares.

A escola registrou quatro anos sem a disponibilidade de professores de recuperação. A iniciativa só foi retomada no ano de 2019, quando uma professora se prontificou a assumir as turmas. No entanto, o trabalho permanece ocioso porque a maior parte dos alunos em recuperação não comparece por dificuldades de transporte (esses alunos dependem do transporte público municipal gratuito, o qual está disponível apenas no horário regular de aulas).

Além dos instrumentos de avaliação anteriormente descritos, a Secretaria Municipal de Educação de São Paulo estabelece que, nesse processo, os alunos do Ciclo de Alfabetização sejam acompanhados também por outros recursos. Por meio das Orientações Didáticas do Currículo da Cidade e, mais precisamente, do Documento Orientador para Sondagem de Língua Portuguesa, norteia-se o diagnóstico da turma no que diz respeito à escrita e à leitura.

Tal instrumento se baseia no pressuposto de que cabe ao professor acompanhar os processos de ensino e de aprendizagem de seus alunos, realizando os ajustes necessários ao planejamento a fim de atender às reais demandas dos estudantes. Nesse sentido, a Secretaria Municipal de Educação de São Paulo aponta a sondagem como um importante recurso de diagnóstico de aprendizagem dos alunos, alegando que esta

permite ao professor acompanhar os avanços e conhecer o que os alunos já sabem em relação à aquisição da base alfabética, para poder intervir de forma mais ajustada nas diversas situações didáticas. (SÃO PAULO, 2018, p. 4)

No ano de 2019, a referida Secretaria definiu como obrigatória a sondagem em todos os alunos do $1^{\circ}$ ao $3^{\circ}$ anos do Ensino Fundamental, e orientou que o diagnóstico inicial da turma seja realizado no início do ano letivo, a fim de garantir a elaboração de um planejamento mais ajustado. 
Assim, a consolidação dos dados obtidos por esse recurso é registrada junto ao Sistema de Gestão Pedagógica (SGP) da Secretaria Municipal de Educação, que procede à análise com o objetivo de propor intervenções nas políticas públicas de alfabetização e de letramento da rede de ensino.

A sondagem a que se refere o documento orientador está fundamentada nas hipóteses apresentadas por Ferreiro e Teberosky (1999); com base nesses estudos, essa avaliação faz a recomendação de que, nos anos iniciais do Ciclo de Alfabetização, os alunos devam escrever uma lista de palavras e uma parlenda, produção que deverá ser realizada sempre ao final de cada um dos bimestres letivos.

Os dados das sondagens de cada turma, na ocasião da presente pesquisa, serão descritos junto à análise dos dados.

\subsection{O Currículo da Cidade e o Projeto Político Pedagógico da escola}

O Currículo da Cidade constitui o marco referencial da rede municipal de ensino de São Paulo. Tendo sido publicado em dezembro de 2017, é fruto de uma parceria entre a Secretaria Municipal de Educação com a UNESCO no Brasil, sendo São Paulo a primeira cidade a lançar o documento em sua versão já alinhada às diretrizes nacionais da BNCC.

Em seu documento-base, o Currículo da Cidade (SÃO PAULO, 2018) optou por utilizar a terminologia "Objetivos de Aprendizagem e Desenvolvimento" para designar o conjunto de saberes que os estudantes da rede municipal de ensino devem desenvolver ao longo do Ensino Fundamental. Nele, os objetivos de aprendizagem e de desenvolvimento orientam-se pela Educação Integral a partir de uma matriz de saberes e indicam o que os discentes devem alcançar a cada ano como resultado das experiências de ensino e de aprendizagem intencionalmente previstas para essa finalidade.

Com base na Síntese da Avaliação Final da Unidade Escolar do ano anterior, e também considerando os resultados finais das avaliações internas e externas (aplicadas pela SME), anualmente a escola reorganiza seu Projeto Político Pedagógico (PPP), tendo em vista os aspectos do trabalho a serem mantidos ou aperfeiçoados no ano seguinte, definindo metas e eixos de ação.

Todos os anos, após sua reformulação pela equipe pedagógica, o PPP é apresentado ao Conselho de Escola, composto inclusive por pais que podem 
questioná-lo e fazer sugestões; entretanto, de fato, isso não se dá de forma significativa, dada a baixa representatividade das famílias na vida escolar.

Ao ser analisado pela Supervisão Escolar (Diretoria Regional de Educação Pirituba-Jaraguá da SME da Prefeitura Municipal de São Paulo), o Projeto Político Pedagógico de 2019 da EMEF Marechal Espiridião Rosas recebeu um parecer técnico, o qual destacava que ele contemplava os seguintes aspectos:

- As sínteses de análise de aproveitamento dos alunos (de acordo com avaliações internas e externas);

- A comparação entre as metas de aprendizagem estabelecidas para os alunos com as propostas estabelecidas pelo Sistema Municipal de Educação (SME) e pelo Indicador de Desenvolvimento da Educação Básica (IDEB);

- As estratégias previstas para o atendimento aos alunos com necessidades especiais, transtornos globais do desenvolvimento e altas habilidades/superdotação;

- O Plano de Gestão e Organização de modo a atender, com qualidade, às demandas da comunidade escolar;

- O Plano de implementação da Proposta Curricular, isto é, a implementação do Currículo da Cidade (a partir dos resultados das avaliações internas da escola, dos resultados das avaliações externas, com ênfase na Prova São Paulo 2018 e em seus indicativos sobre os níveis de aprendizagem dos estudantes; dos objetivos de aprendizagem por ciclo e por ano; da meta de alfabetizar $100 \%$ dos alunos até o final do Ciclo de Alfabetização; da recuperação das aprendizagens dos alunos e diminuição da reprovação escolar);

- As ações de estudo e de implementação do Currículo da Cidade por meio do PEA (Projeto Especial de Ação), o qual define diretrizes de aprendizagem para todos os alunos, garantindo a recuperação paralela e diminuindo a reprovação;

- Os projetos de ação para atividades curriculares desenvolvidas no contraturno escolar.

Ao analisarmos o referido Projeto, observamos que ele apresenta descritores claros a respeito de metas e de estratégias de ação; no entanto, deixa de considerar aspectos contextuais relevantes, ignorando que toda ação se dá em circunstâncias 
específicas, que determinam o sucesso - ou não - da concretização dos objetivos propostos. Nesse sentido, destacamos como ausência de dados importantes:

- O estudo diagnóstico da comunidade e do espaço em que a escola está inserida, isto é, dados referentes ao perfil socioeconômico dos alunos e de suas famílias, bem como sua correspondência com os indicadores de desenvolvimento da região em que a escola se encontra;

- O perfil sociocultural dos profissionais que atuam na escola e a indicação de como potencializar as condições de atendimento à comunidade;

- O mapeamento das adjacências da escola no que se refere ao entorno social, à saúde, ao lazer e à cultura da região, bem como sua articulação com a unidade escolar.

\subsection{Recursos didáticos do ensino de Língua Portuguesa}

Tendo em vista as orientações curriculares da Secretaria Municipal da Educação, as avaliações anteriormente descritas e o PPP da unidade escolar, procedemos à algumas considerações sobre os materiais e os recursos didáticos destinados ao alcance das metas de ensino e aprendizagem.

Entendendo que a aprendizagem da Língua Portuguesa se dá por meio de práticas sociais diversas (falar, ouvir, ler e escrever), o documento que orienta o ensino de Língua Portuguesa está organizado nos seguintes eixos: prática de leitura de textos, prática de produção de textos escritos, prática de escuta e produção de textos orais e prática de análise linguística. ${ }^{27}$

Esses eixos se encontram presentes no material distribuído aos alunos (livro didático) e no material de orientações didáticas disponibilizado aos professores de cada área do conhecimento. Ambos são entregues a toda a rede municipal, gratuitamente, no início do ano letivo.

Ao longo da pesquisa, foi possível observar o uso desse material em algumas aulas. No entanto, não houve, em circunstância alguma, alusão às orientações do material, verificando-se que cada professor faz uso da maneira como entende ser possível.

27 SÃO PAULO. (Cidade). Currículo de língua portuguesa para a cidade de São Paulo. 2017. Disponível em: http://patiodigital.prefeitura.sp.gov.br/wp-content/uploads/sites/4/2017/05/Leiturapr\%C3\%A9via_curr\%C3\%ADculo-LP_1\%C2\%BA-encontro.pdf. Acesso em: 19 jul. 2019. 
Tendo sido consultados os professores a esse respeito, foi unânime a explicação de que se trata de um material difícil para os alunos, uma vez que ainda não leem, nem escrevem.

Para resolver o problema, optaram por fazer uso de atividades no caderno e com fotocópias, muitas retiradas da internet ou idealizadas pelos próprios professores.

Decidiram, também, pela adesão a outro livro didático, considerado "mais fácil" que o material referenciado no Currículo da Cidade. Assim sendo, adotaram os livros da Coleção Buriti28, dentre os quais, para os fins desta pesquisa, destacamos o volume "Buriti Mais Português" como material didático a ser utilizado nas aulas de Língua Portuguesa.

Figura 11 - Livro didático dos alunos das séries iniciais do Ensino Fundamental

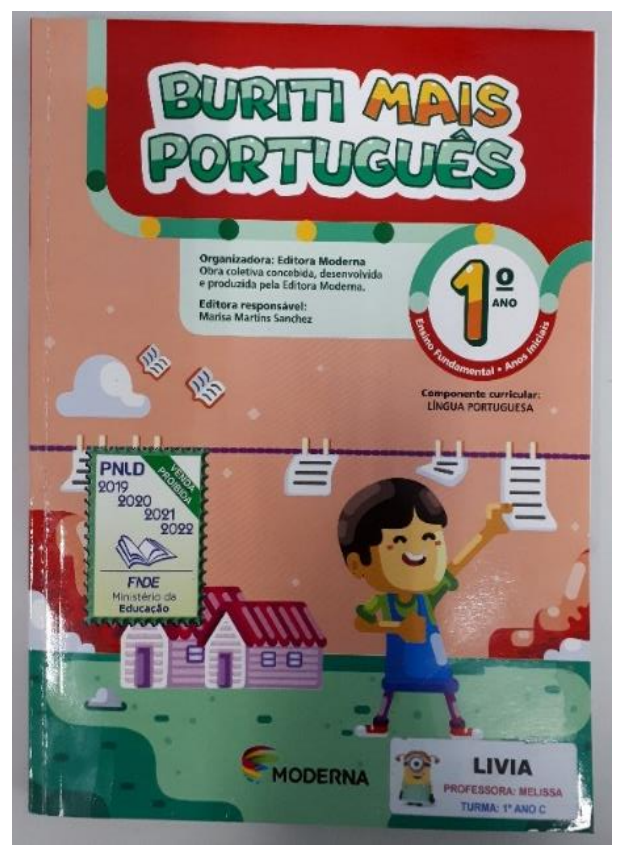

Fonte: a pesquisadora

Assim, ao longo do ano letivo, os alunos trabalham, simultaneamente, com dois materiais distintos, mas que partem de pressupostos teóricos não necessariamente convergentes. ${ }^{29}$

Tendo sido contextualizada a escola foco desta pesquisa, a seguir, descreveremos brevemente o perfil das turmas estudadas e o percurso pelo qual nos orientamos para realizar a análise dos dados.

${ }^{28}$ A referida coleção é de publicação da Editora Moderna, e seus títulos abordam conteúdos das diferentes áreas de conhecimento.

29 Os livros didáticos e guias de orientação ao professor do Currículo da Cidade encontram-se disponíveis em: http://portal.sme.prefeitura.sp.gov.br/Main/Page/PortalSMESP/Publicacoes InstitucionaisDIEFEM. Acesso em: 20 set. 2019. 


\section{PROFESSORES E ALUNOS NO CONTEXTO DA PESQUISA}

Com o objetivo de traçar um panorama contextual, este capítulo apresenta o perfil de cada turma investigada, bem como das professoras que participaram da pesquisa. Em alguns dias, foi possível observar mais de uma proposta em que a escrita se fez presente, assim como atividades que envolviam práticas de leitura e de oralidade.

\subsection{O primeiro ano}

A professora desta turma, a partir de agora chamada Bianca ${ }^{30}$, tem 38 anos de idade. Tem graduação em Pedagogia, mas não possui formação complementar. Há dez anos exerce cargo efetivo na rede pública municipal, atuando há três na unidade escolar foco desta pesquisa, no período da tarde. Atua também na rede pública estadual, exercendo, pela manhã, docência no Ensino Fundamental I.

Segundo ela, sua escolha profissional se justifica pelo apreço que sempre teve pelo ambiente escolar: desde que era bem pequena, gosta do dia a dia da escola. Apesar disso, inicialmente cogitou também enveredar para a Psicologia, mas, ao começar o curso de Pedagogia, apaixonou-se pela docência como carreira.

Integrante assídua da JEIF (Jornada Especial Integral de Formação) conduzida pela Coordenação Pedagógica, participa das reuniões semanais de estudo e de reflexão na escola, as quais perfazem o total de $1 \mathrm{~h} 40$ semanais. Sua percepção é de que esses encontros são formativos, mas pontua que têm muito a melhorar, pois pouco influenciam no trabalho efetivo em sala de aula. A seleção da bibliografia a ser estudada é feita pelos professores, mas, tendo estes pouco tempo disponível e parca clareza do que é relevante estudar, terminam por fazer escolhas de última hora, sem critérios bem definidos; aponta, também, que seria importante para os professores acessarem referenciais bibliográficos que não se restrinjam aos oferecidos pela rede pública, sendo interessante o acesso a um acervo que trate também de questões associadas mais à prática docente, e menos à teoria.

Durante a entrevista, observamos que Bianca se mostrou muito segura ao fazer comentários e observações, deixando evidente que sua ampla experiência

30 Os nomes aqui utilizados são fictícios, uma vez que os sujeitos da pesquisa tiveram seus nomes originais alterados com o objetivo de garantir sua privacidade. 
profissional the confere um lugar confortável na relação que mantém com a docência, e, particularmente, com o ensino de Língua Portuguesa.

Ao longo da observação, foi possível presenciar diversas situações em que se mostrou uma professora comprometida com a aprendizagem de seus alunos: preocupada em fazer com que avançassem, propunha atividades diferentes para os que apresentavam dificuldades, bem como os acompanhava enquanto trabalhavam, tentando esclarecer as dúvidas que apresentavam.

Mostrou-se presente na relação com eles, que a escutam com atenção e a obedecem prontamente. Contudo, bastante exigente e apresentando altas expectativas em relação ao próprio desempenho e ao deles, por vezes, demonstrava certa braveza, dirigindo-se a alunos com aparente zanga, o que não se confirmava pelo modo como se preocupava com eles quando tinham algum problema.

A turma do primeiro ano ${ }^{31}$ tem 29 alunos matriculados, sendo 12 meninas e 17 meninos, que têm, em média, seis anos de idade. Não há distorções significativas entre idade/série, a não ser pela presença de uma criança (um ano mais velha) que permaneceu por um ano fora da escola, retornando na ocasião desta pesquisa. Há, também, um aluno considerado "de práticas inclusivas", pois ele tem um laudo que atesta possuir necessidades educativas especiais. Apesar disso, a professora alega "não saber exatamente o que ele tem", o que parece justificar que não participe das propostas de trabalho feitas aos demais alunos. Durante a observação, foi constatado que ele permanecia a maior parte do tempo vagando pela sala, explorando objetos e espaços, sem que quaisquer adaptações curriculares lhe permitisse ser integrado à turma ou incluído ao trabalho pedagógico.

$\mathrm{Na}$ entrevista concedida à pesquisadora, Bianca explicou que não espera que este aluno aprenda a escrever ou a ler, uma vez que apenas rabisca; seu objetivo, no entanto, é que possa interagir com as demais crianças. Admite, também, "não dar conta dele", e afirma saber que o ideal seria dar-Ihe mais atenção, mas alega que os demais alunos também exigem muito dela; assim sendo, o aluno em questão fica mais a cargo da professora estagiária, que cuida dele enquanto Bianca atende às demandas das demais crianças da turma.

${ }^{31}$ As denominações originais das classes também foram alteradas a fim de garantir a privacidade; assim sendo, serão chamadas Turma do Primeiro Ano e Turma do Segundo Ano do Ensino Fundamental. 
Quanto à organização da sala de aula, observa-se, ao fundo, três pequenos armários, nos quais se encontram os livros e cadernos dos alunos, além de alguns livros de literatura. Na parte da frente da sala há uma lousa que ocupa toda a parede e, ao lado da mesa da professora, há outro armário, em que são guardados os materiais que ela utiliza com maior controle; daí permanecer fechado quando a turma não está em aula. Acima da lousa há um grande alfabeto, escrito em letra de imprensa - maiúscula e minúscula, além de letra cursiva.

Nas paredes é possível ver, à disposição dos alunos, alguns cartazes com material de consulta, como um quadro de números e a lista de nomes da turma. Não foi observada uma biblioteca de classe, nem qualquer espaço destinado à leitura dos alunos em sala.

Em geral, as carteiras estão dispostas em fileiras e cada aluno trabalha individualmente; há vezes, contudo, em que estas ficam dispostas em fileiras formadas por duplas de carteiras, o que não garante as interações, uma vez que os alunos seguem trabalhando sozinhos.

Figura 12 - Sala de aula $1^{\circ}$ ano - vista frontal

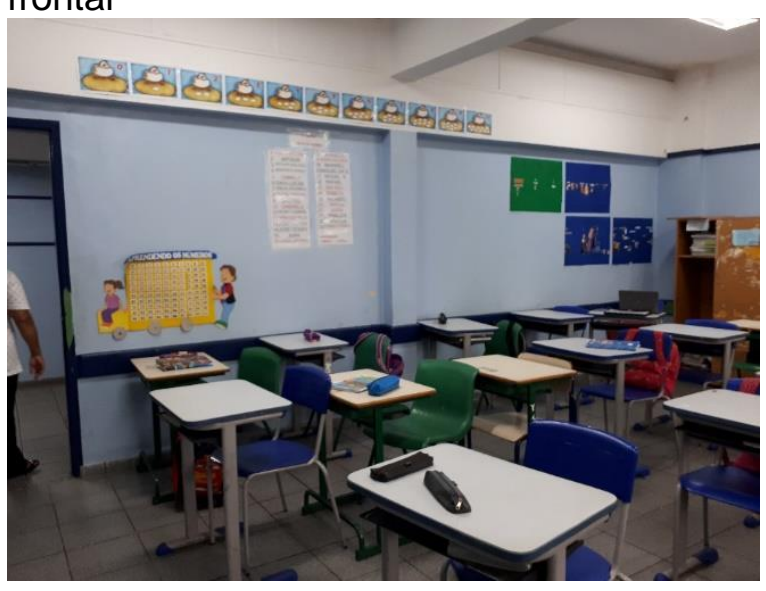

Figura 13 - Sala de aula $1^{\circ}$ ano - vista lateral a

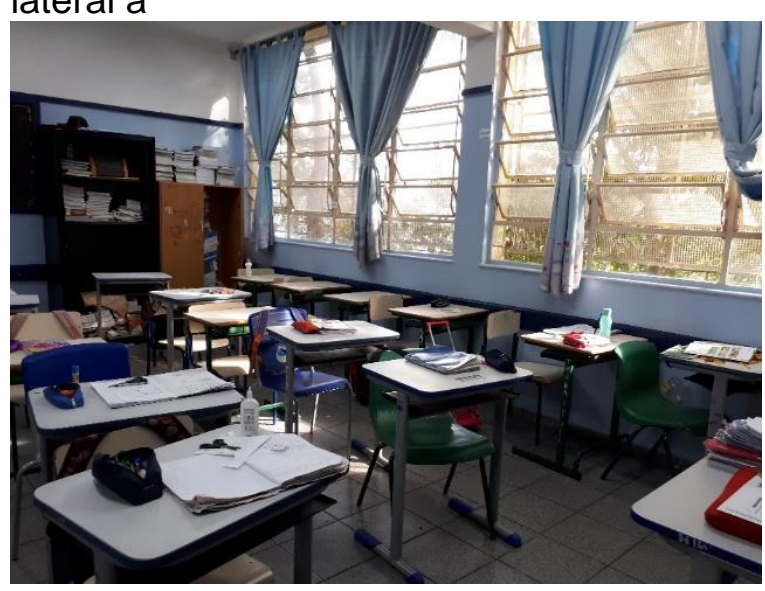


Figura 14 - Sala de aula $1^{\circ}$ ano - vista lateral b

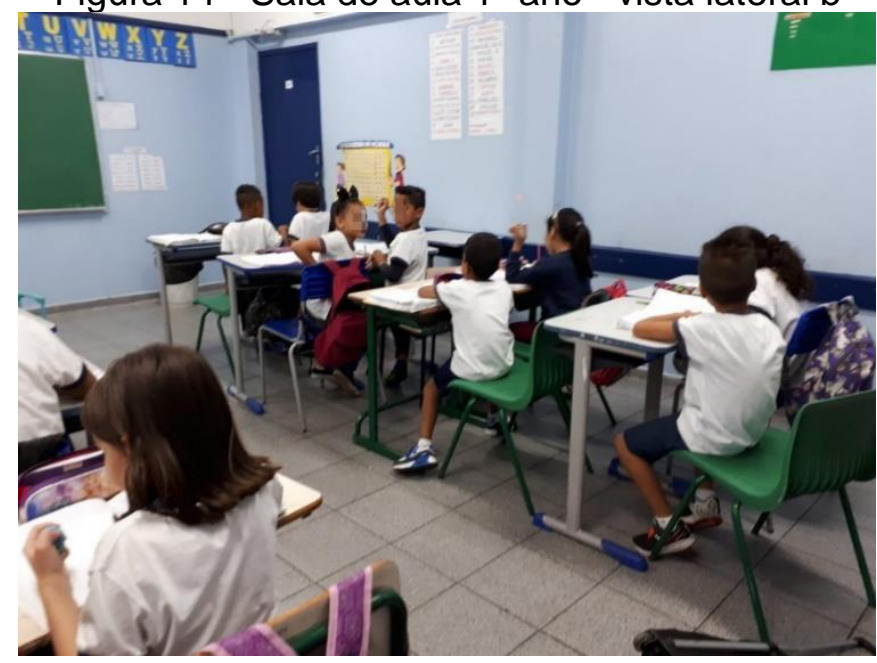

\subsection{O segundo ano}

A professora Raquel tem 44 anos e é a responsável por esta turma; formou-se primeiro no Curso de Magistério e, posteriormente, em Pedagogia, tendo se formado em 1998. Antes de ingressar na docência, atuou em empresas nas áreas de Contabilidade e de Recursos Humanos.

Ao justificar sua opção profissional, explicou que a mãe também foi professora, o que influenciou sua escolha pela carreira docente. Conta que, quando cursou o nível que atualmente corresponde ao Ensino Médio, deveria optar entre os cursos Colegial ou Magistério, e decidiu-se por este porque Ihe permitiria ter uma profissão ao concluilo, o que se deu quando já atuava em empresas. Com o tempo, foi se dando conta que a Matemática Financeira não a atraía o suficientemente para fazer disso uma profissão; daí, devido à formação anterior, decidiu enveredar para o curso de Pedagogia.

Há 13 anos atua como docente, sendo professora efetiva da rede pública estadual desde 1999 e, da rede pública municipal, desde 2006; na unidade foco desta pesquisa, exerce a docência há dez anos.

Sempre que the é possível, participa das reuniões de JEIF, cumprindo a carga horária suplementar à sala de aula por $1 \mathrm{~h} 40$ semanais. Entende que esses momentos são importantes porque lhe permitem o aperfeiçoamento profissional devido às leituras e às discussões que são promovidas. 
Contudo, avalia que os temas de estudo são muito amplos, genéricos, de forma que não permitem aos professores avançarem nas questões específicas da prática pedagógica. Aponta, também, que é muito difícil transpor para a prática o que é discutido a partir da teoria, o que não a auxilia a pensar sobre a forma como atua junto aos alunos.

Durante a entrevista, Raquel se mostrou disponível e, ao longo da conversa, fez, com segurança, observações ao justificar suas colocações. Tranquila e experiente, demonstrou apreço pela docência, ao mesmo tempo em que revelou certo desânimo diante das dificuldades que enfrenta no dia a dia com os alunos.

Ao longo da observação realizada pela pesquisadora, foi possível notar que a turma é muito agitada e falante; as crianças enfrentam diversos conflitos entre si, e a presença da professora Raquel pouco interfere na convivência e na aprendizagem dos alunos, uma vez que ela é pouco ouvida por eles.

Em sala de aula, Raquel se mostra preocupada em propor boas situações de aprendizagem aos alunos, mas, frequentemente, tem muitas dúvidas sobre as atividades que propõe, bem como a respeito da própria atuação. Como nem sempre planeja o trabalho de modo a contemplar as diferentes questões de aprendizagem, frequentemente, é difícil para ela atender às demandas que os alunos apresentam, o que a leva a fazer proposições genéricas de trabalho, iguais para todos.

Nesta turma há 28 alunos matriculados, sendo 20 meninas e 8 meninos. Não há casos de distorção entre idade/série, e não há alunos "de práticas inclusivas". A esse respeito, durante a entrevista, Raquel esclareceu que, embora alguns deles tenham muitas questões importantes de aprendizagem, nenhum tem laudo clínico ou psicológico que justifique considerá-lo "alunos de inclusão".

A sala de aula, na maior parte do tempo, está organizada para o trabalho individual, tendo as carteiras dispostas em fileiras.

$\mathrm{Na}$ parte da frente da sala, há um grande quadro branco que ocupa toda a parede, e três armários que acondicionam os pertences da professora e os materiais didáticos, acessados exclusivamente por ela. No fundo da classe, há dois armários com livros e outros recursos, que não foram utilizados pela turma durante a observação feita pela pesquisadora. Nas paredes, há poucos cartazes e materiais para pesquisa dos alunos, não havendo qualquer tipo de mural para uso do professor ou dos alunos. 
Figura 15 - Sala de aula $2^{\circ}$ ano - vista lateral

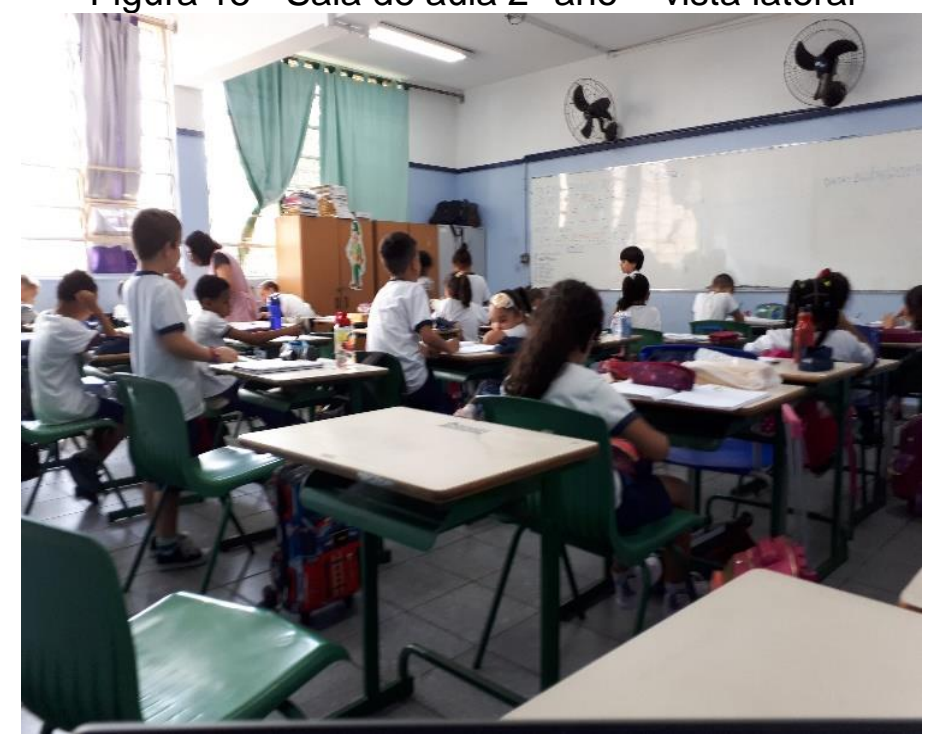

\subsection{Observações gerais}

A partir do que foi descrito, entendemos ser importante - para a análise dos eixos de investigação que se seguirão nos próximos capítulos - fazer algumas considerações sobre o que foi observado na organização das salas de aula; isso porque partimos do conceito de espaço como lugar.

Segundo Norberg-Schulz (1980 apud REIS, 2017), sob essa ótica, a noção de espaço e de arquitetura transcendem o aspecto físico funcional, abarcando as interrelações e intersubjetividades daqueles que ali habitam, uma vez que o homem transforma o ambiente ao mesmo tempo em que é por ele transformado.

Observamos a presença de materiais gráficos nas paredes das duas classes. Entretanto, chama a nossa atenção observar que, embora estes estejam à disposição dos alunos, durante a presença da pesquisadora, nenhum deles foi lido ou consultado pelas crianças durante o trabalho; de fato, elas pareciam não se dar conta de que esse material ali estava, tal as professoras, que nunca se remetiam a eles. Assim, ainda que não haja murais formalmente estruturados, as paredes cumprem o papel de ser cenários para a alocação de listas de nomes, do alfabeto, do quadro de números e dos cartazes temáticos.

Todavia, aqui vale apontar a existência de uma contradição: se esses materiais sequer eram observados, como se constituíram como referenciais de consulta aos alunos? Essa seria, a princípio, uma finalidade que justificaria sua presença. 
O mesmo ocorreu com os livros de literatura, sempre presentes nas classes, mas não à disposição direta dos alunos. E quando estavam à vista, os alunos não eram instigados a ler, dirigida ou espontaneamente, tampouco com ajuda do professor; pelo contrário, na maior parte do tempo, os livros estavam acondicionados em caixas de papelão ou guardados dentro do armário do professor.

Quanto aos aspectos físicos, as salas apresentavam boa luminosidade, mas a circulação de ar não era favorecida, o que interferia no envolvimento dos alunos em dias mais quentes; a acústica das classes não se mostrou um problema.

Carteiras e mesas encontravam-se em razoável estado de conservação, mas isto não ocorria com a limpeza, que, por vezes, não era a mais eficiente.

Segundo o que foi apontado pelos professores, dado que ambas turmas dividiam a classe com séries de outro segmento no período do contraturno, os armários tinham que estar sempre bem trancados; caso contrário, no dia seguinte à aula, não seria possível encontrar os materiais didáticos, nem pessoais. Como alguns armários tinham suas fechaduras violadas, os professores apelavam para um trancamento caseiro, utilizando fitas adesivas e cordas, o que também não garantia a segurança do que ali se encontrava.

Do poder público, as crianças recebiam materiais básicos, como cadernos, lápis, borracha, cola e tesoura. No entanto, a quantia e a qualidade destes eram insuficientes; mesmo assim, tais materiais não eram repostos ao longo do ano, o que exigia que os alunos os trouxessem de casa.

Segundo relatado pelos professores, essa situação fazia com que os alunos comprassem com recursos próprios os materiais, os quais ficavam escondidos nos armários.

Entendemos ser relevante apontar essas questões por compreender que a falta de subsídios - materiais ou não - interfere na qualidade do trabalho docente, bem como nas condições de aprendizagem discente. Isto é notório também quando se avaliam práticas pedagógicas, tais como espalhar cartazes e disponibilizar livros e outros recursos, com função didática ou não, o que faz pensar, especialmente, quando se trata de turmas de crianças que se encontram em processo de alfabetização.

Nos próximos capítulos, procederemos à análise de cada eixo de pesquisa, considerando também os pontos de observação levantados, buscando articulá-los às concepções e às práticas docentes. 


\section{PERCURSO DE ANÁLISE DOS DADOS}

Tendo sido, portanto, caracterizadas a escola e as turmas estudadas, neste capítulo pretendemos esclarecer o percurso de análise dos dados coletados durante a investigação. Para isso, organizamos o estudo das informações obtidas do seguinte modo:

1. Apresentação das concepções docentes (Quadro-síntese) sobre a língua escrita, a aprendizagem e as interações presentes nas entrevistas realizadas com cada professor;

2. Apresentação das propostas didáticas de ensino da escrita feitas aos alunos de cada uma das turmas observadas (Quadro-síntese);

3. Análise das tendências apontadas, buscando a relação entre as concepções docentes e as tarefas de escrita propostas aos alunos.

A seguir, apresentamos a organização dos dados de acordo com os âmbitos de análise descritos no capítulo cinco.

\section{1 Âmbito discursivo (entrevistas)}

Considerando a língua, a aprendizagem e as interações sociais como eixos de análise, no âmbito discursivo, tomamos as entrevistas realizadas com os professores para identificar as referências conceituais que subsidiam suas práticas, buscando evidenciar as concepções que norteiam seu trabalho.

As entrevistas realizadas tratam de identificar o que cada professor pensa e declara ensinar sobre a língua, isto é, delinear os critérios que fundamentam sua ação em sala de aula e as propostas didáticas que faz. Ademais, buscam indicar como tais docentes veem as interações entre professor e alunos, bem como destes entre si, no processo de aprender.

Como se verá adiante, os professores responderam às perguntas descritas no capítulo cinco. Além disso, ao longo da "conversa", outros aspectos ganharam relevância em vista do que era apontado pelos próprios professores. Houve casos também em que se fez oportuno compreender melhor algo observado em sala de aula, tendo este momento sido propício para esclarecer determinadas questões. Nesse sentido, optamos por acrescentar comentários dos professores, ou seja, observações 
que julgamos relevantes para a referida análise. Dentre esses excertos, destacamos os resultados das sondagens realizadas à época da presente investigação, assim como a leitura dos professores a esse respeito.

\section{2 Âmbito da prática pedagógica}

No âmbito da prática, analisamos o fazer pedagógico desses mesmos professores, averiguando o modo como suas concepções se articulam à prática pedagógica. Para isso, avaliamos as propostas didáticas que fizeram aos alunos, bem como de que modo a ação docente e as interações intervêm nos (ou afetam os) processos de aprendizagem.

Para analisar os dados coletados e entender como se dá, efetivamente, o ensino da língua nas classes observadas, destacamos os aspectos priorizados pelos professores.

Para sintetizar os dados, decidimos pela organização por turma, considerando os eixos de análise propostos inicialmente. Assim, procedemos ao estudo de cada classe apresentando um quadro-síntese das propostas de trabalho feitas aos alunos, a partir do qual buscamos pontos de referência para embasar a reflexão sobre a relação entre os âmbitos discursivo e prático.

Ao organizar, nos quadros-síntese, as atividades propostas aos alunos nas aulas de Língua Portuguesa, ordenamos as atividades por data. Contudo, diferenciamos as atividades que ocorreram pontualmente (apresentam apenas números isolados, como 1, 2 e 3) daquelas em que as proposições estavam articuladas entre si ou eram subsequentes (aparecem com numeração separada por pontos, como 1.1, 1.2 e 1.3); assim, procuramos separar as atividades independentes das que tinham alguma dependência entre si. Igualmente, indicamos por números seguidos de letras (como 1a, 1b) sempre que a professora fez propostas diversificadas, isto é, quando um grupo ou algum aluno fazia atividades de escrita que diferiam das dos demais alunos da classe.

Nas atividades de escrita, diferenciamos também aquelas em que os alunos escreveram sob circunstancias distintas; assim, aparecem no quadro-síntese as seguintes denominações: ESCRITA DE PALAVRAS/FRASES/TEXTO, a fim de explicitar quando os alunos escreveram segundo as próprias hipóteses; ESCRITA 
COLETIVA, para demonstrar quando a professora foi a escriba da turma; e CÓPIA DE PALAVRAS/FRASES/TEXTO, quando copiaram aquilo já escrito por outro.

Com base nas atividades observadas, organizamos as informações a partir da natureza das propostas, tipificando-as pelos eixos de investigação descritos no capítulo cinco.

No eixo de análise LíNGUA, abordamos como categorias de análise as Práticas de Linguagem e as Dimensões Linguísticas presentes nas propostas de escrita em sala de aula.

$\mathrm{Na}$ categoria Práticas de Linguagem são analisadas as ações em que a linguagem se faz presente nos âmbitos da oralidade (O), da leitura $(L)$ e da escrita (E). Cabe destacar que, sem desconsiderar a importância de compreender tais práticas como ações interligadas, para efeitos da presente pesquisa, ocupamo-nos especificamente da escrita por ser este nosso foco de investigação. Desse modo, os comentários tecidos sobre os âmbitos leitura e oralidade somente se fazem presentes quando entendemos que estes podem esclarecer elementos em relação ao ensino da língua.

Ao abordarmos as Dimensões Linguísticas das diferentes atividades, buscamos observar se o conhecimento linguístico em pauta diz respeito aos aspectos notacionais $(\mathrm{N})$ ou discursivos $(\mathrm{D})$ da língua.

Para tal, consideramos que os aspectos notacionais dizem respeito às características da representação gráfica da linguagem, mais especificamente, ao sistema de representação convencional da escrita alfabética; já os aspectos discursivos referem-se às características da linguagem em uso (a organização linguística da mensagem), em que são considerados, por exemplo, os propósitos e as situações comunicativas, a relação entre os interlocutores e o contexto sociocultural das produções.

Considerando que o alfabetismo compreende aprender $\mathrm{e}$ apreender simultaneamente as duas dimensões - a notacional e a discursiva, a seguir, apontamos suas particularidades. 
ASPECTOS NOTACIONAIS:

- Sistema de escrita (correspondência fonográfica);

- Separação entre palavras;

- Recursos do sistema de pontuação: maiúscula inicial, ponto final, exclamação, interrogação, reticências, dois pontos, travessão, aspas e vírgula;

- Discurso direto e indireto;

- Regularidades e irregularidades ortográficas;

- Acentuação das palavras: regras gerais relacionadas à tonicidade;

- Produção de textos utilizando estratégias de escrita: planejar o texto, redigir rascunhos, revisar e cuidar da apresentação.

- Controle da legibilidade do escrito.

ASPECTOS DISCURSIVOS:

- Características textuais de cada gênero;

- Recursos coesivos, conectivos e expressões temporais e causais;

- Substituições lexicais, manutenção do tempo verbal;

- Emprego de regência verbal e concordância verbal e nominal. (BRASIL, 1997, p. 3-4)

No eixo de análise APRENDIZAGEM, buscamos examinar os dados obtidos, considerando que os processos de ensino e de aprendizagem se encontram intimamente relacionados. Assim, a segmentação aqui apresentada tem apenas a finalidade de favorecer a análise das informações coletadas.

Haja vista a dificuldade de classificação precisa desses processos, optamos por critérios que, sem uma conotação dicotômica, procuram caracterizar o que prevaleceu na situação pedagógica em um continuum de possibilidades, posturas ou comportamentos (mais passivos ou mais reflexivos, mais transmissivos ou mais construtivos).

Ao abordar as Perspectivas de Aprendizagem, referimo-nos às concepções de ensino e aprendizagem apontadas no capítulo dois. Para tanto, buscamos distinguir quando a proposição e a realização da tarefa pressupunham uma atitude mais passiva do aprendiz $(\mathrm{P})$, de quando priorizava construção de conhecimentos por parte dele, por meio da reflexão (R). Apontamos, igualmente, as situações em que a tarefa pressupunha algum nível de reflexão, mas não garantia a mobilização de recursos de análise linguística por parte do aluno. Encontram-se aqui $(P-R)$ as atividades que, em alguma medida, acionavam o uso de recursos cognitivos, mas não asseguravam a 
análise das regularidades do sistema alfabético, nem promoviam a construção de conhecimentos pela elaboração e reelaboração de hipóteses sobre a língua.

Em relação às Perspectivas de Ensino, tratamos de observar quando a ação docente, na condução das atividades, embasava-se mais no ensino por transmissão $(T)$, isto é, implicava uma posição em que o professor detinha o saber e o informava ao aluno (principalmente pela repetição e memorização de informações), e quando as propostas se sustentavam mais no ensino pela participação ativa do sujeito, ou seja, favorecendo a construção do conhecimento (CC).

No eixo INTERAÇÃO, consideramos o modo como professor e alunos estavam organizados para cada tarefa e de que forma a interação verbal foi - ou não - mediada pelo diálogo.

Quanto à Organização da Turma, tratamos de analisar se os alunos trabalharam sozinhos, individualmente (I), em duplas (D), em pequenos grupos (PG) ou junto ao professor, todos em grande grupo (GG).

Quando observamos a categoria Processos de Interação, investigamos a presença ou não do diálogo mediando as relações, bem como quem eram os interlocutores em questão. Desse modo, procuramos diferenciar situações em que o diálogo não se fez presente (Práticas Não Dialogadas - PND) daquelas em que houve interação verbal (Práticas Dialogadas - PD), nas quais procedemos à especificação de quem eram os interlocutores; assim, temos Práticas Dialogadas entre professor e alunos (PD-PA) e Práticas Dialogadas entre alunos (PD-AA).

Tendo sido descrito o percurso de investigação das informações levantadas durante a pesquisa, bem como as categorias indicadas em cada eixo de investigação, nos próximos capítulos empreenderemos propriamente a análise dos dados obtidos, buscando entender como, a partir de mesmas diretrizes educacionais e pedagógicas, o projeto de alfabetização se concretiza e, eventualmente, modifica-se segundo as concepções docentes. 


\section{CONCEPÇÕES E PRÁTICAS DE ESCRITA NO PRIMEIRO ANO}

Neste capítulo, pretendemos analisar os dados do primeiro ano com base na entrevista realizada com a professora e nos registros de observação em classe, a fim de articular as concepções (explícitas ou implícitas) e a prática docente.

\subsection{Concepções Docentes e Práticas Pedagógicas}

No que diz respeito às concepções depreendidas da entrevista com a professora Bianca, responsável pelo $1^{\circ}$ ano, o Quadro 13, a seguir, sintetiza seus posicionamentos relativos à língua, ensino e aprendizagem e interação. 
Quadro 13 - Concepções assumidas pela professora Bianca - 1ํano (Entrevista) ${ }^{32}$

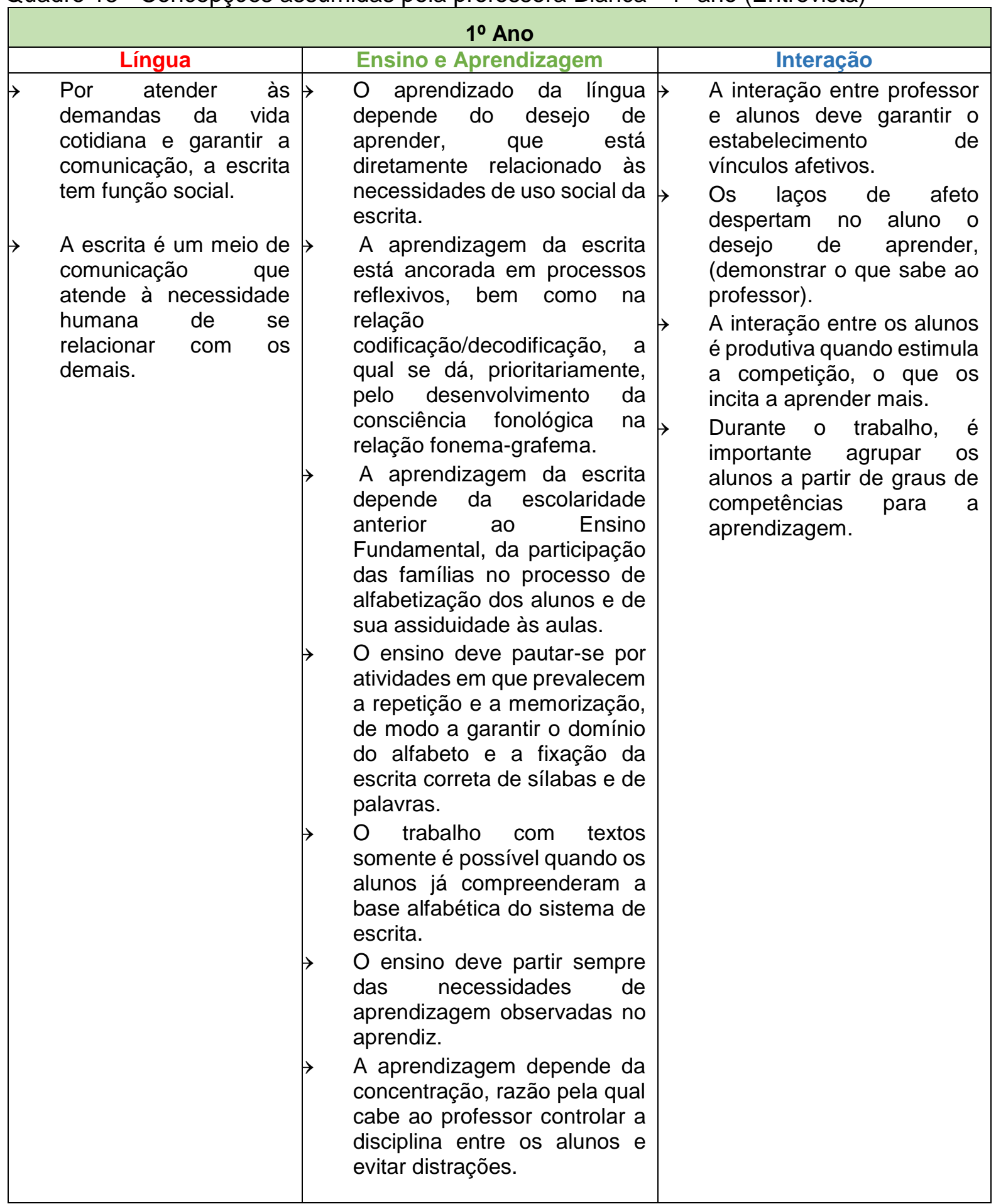

Fonte: elaborado pela pesquisadora.

No que diz respeito à prática em sala de aula, a professora propôs 26 atividades destinadas ao ensino da língua, sintetizadas no Quadro 14, a seguir.

32 Questões da entrevista (já mencionadas no capítulo 5): Para você, o que é a língua escrita? De que modo a criança aprende a língua escrita? Como a escrita deve ser ensinada na escola? Como você vê as interações (entre alunos e entre alunos e o professor) e a aprendizagem da língua? 
Quadro 14 - Propostas de escrita junto aos alunos do $1^{\circ}$ ano

\begin{tabular}{|c|c|c|c|c|c|c|c|c|}
\hline \multirow[b]{3}{*}{$\begin{array}{l}\text { Ordem } \\
\text { das } \\
\text { atividades } \\
\text { propostas }\end{array}$} & & & \multicolumn{2}{|c|}{ LÍNGUA } & \multicolumn{2}{|c|}{ APRENDIZAGEM } & \multicolumn{2}{|c|}{ INTERAÇÃO } \\
\hline & & & $\begin{array}{l}\text { Práticas de } \\
\text { Linguagem }\end{array}$ & $\begin{array}{l}\text { Dimensões } \\
\text { Linguísticas }\end{array}$ & $\begin{array}{c}\text { Perspectivas } \\
\text { de } \\
\text { Aprendizagem }\end{array}$ & $\begin{array}{l}\text { Perspectivas } \\
\text { de Ensino }\end{array}$ & $\begin{array}{l}\text { Organização } \\
\text { da turma }\end{array}$ & $\begin{array}{l}\text { Processos } \\
\text { de interação }\end{array}$ \\
\hline & Data & Descrição da atividade & $\begin{array}{l}\text { Oralidade } \\
\text { (O) } \\
\text { Leitura } \\
\text { (L) } \\
\text { Escrita } \\
\text { (E) }\end{array}$ & $\begin{array}{l}\text { Aspectos } \\
\text { Notacionais } \\
\text { (N) } \\
\text { Aspectos } \\
\text { Discursivos } \\
\text { (D) }\end{array}$ & $\begin{array}{l}\text { Passiva } \\
\quad(P) \\
\text { Reflexiva } \\
\quad(\mathrm{R}) \\
\\
\text { Passivo- } \\
\text { Reflexiva } \\
\text { (P-R) }\end{array}$ & $\begin{array}{c}\text { Construção } \\
\text { Cognitiva } \\
\text { (CC) } \\
\text { Transmissão } \\
\text { (T) }\end{array}$ & $\begin{array}{c}\text { Trabalho } \\
\text { Individual (I) } \\
\text { Trabalho em } \\
\text { Dupla (D) } \\
\text { Trabalho em } \\
\text { Pequenos } \\
\text { Grupos } \\
\text { (PG) } \\
\text { Grande Grupo } \\
\text { (GG) }\end{array}$ & $\begin{array}{c}\text { Práticas } \\
\text { Dialogadas } \\
\text { Professor- } \\
\text { Aluno } \\
\text { (PD-PA) } \\
\text { Práticas } \\
\text { Dialogadas } \\
\text { (PD-AA) } \\
\text { Aluno-Aluno } \\
\\
\text { Práticas Não } \\
\text { Dialogadas } \\
\text { (PND) }\end{array}$ \\
\hline $1 \mathrm{a}$ & $07 / 03$ & $\begin{array}{l}\text { Escrita de palavras a partir de figuras } \\
\text { (nomes de brinquedos) }\end{array}$ & $E$ & $\mathrm{~N}$ & $R$ & $\mathrm{CC}$ & 1 & PND \\
\hline $1 \mathrm{~b}$ & $07 / 03$ & $\begin{array}{l}\text { Escrita de palavras a partir de sílabas } \\
\text { desordenadas (objetos diversos) }\end{array}$ & $E$ & $\mathrm{~N}$ & P-R & $\mathrm{T}$ & D & PD-PA \\
\hline 2 & $08 / 03$ & $\begin{array}{l}\text { Escrita de nomes de brinquedos (pelo } \\
\text { número de sílabas que os compõem) }\end{array}$ & $\mathrm{E}$ & $\mathrm{N}$ & P-R & $\mathrm{T}$ & GG & PD-PA \\
\hline
\end{tabular}




\begin{tabular}{|c|c|c|c|c|c|c|c|c|}
\hline 3 & 08/03 & $\begin{array}{l}\text { Cópia de palavras separando-as em } \\
\text { sílabas (nomes de brinquedos) }\end{array}$ & $E$ & $\mathrm{~N}$ & $P$ & $\mathrm{~T}$ & 1 & PD-PA \\
\hline 4 & $12 / 03$ & $\begin{array}{l}\text { Escrita de palavras com mudança de } \\
\text { sentido pela troca de letras (BOLA, } \\
\text { COLA) }\end{array}$ & $E$ & $\mathrm{~N}$ & P-R & $\mathrm{T}$ & GG & PD-PA \\
\hline 5 & $13 / 03$ & $\begin{array}{l}\text { Leitura de parlenda (Um, dois, feijão } \\
\text { com arroz) }\end{array}$ & $\mathrm{L}$ & D & $\mathrm{R}$ & CC & 1 & PD-PA \\
\hline $5.1 \mathrm{a}$ & $13 / 03$ & $\begin{array}{l}\text { Cópia dos nomes dos números de } 1 \text { a } \\
\text { 10, escritos por extenso em uma } \\
\text { parlenda (Um, dois, feijão com arroz) }\end{array}$ & $E$ & $\mathrm{~N}$ & P & $\mathrm{T}$ & 1 & PND \\
\hline $5.1 b$ & $13 / 03$ & $\begin{array}{l}\text { Escrita de palavras (objetos diversos) a } \\
\text { partir de sílabas desordenadas }\end{array}$ & $E$ & $\mathrm{~N}$ & P-R & $\mathrm{T}$ & $\mathrm{GG}$ & PD-PA \\
\hline 6 & $14 / 03$ & $\begin{array}{l}\text { Leitura de cantiga (Com quem você } \\
\text { pretende se casar?) }\end{array}$ & $\mathrm{L}$ & D & $\mathrm{R}$ & $\mathrm{CC}$ & GG & PD-PA \\
\hline 6.1 & $14 / 03$ & $\begin{array}{c}\text { Cópia do alfabeto a partir de uma } \\
\text { cantiga (Com quem você pretende se } \\
\text { casar?) }\end{array}$ & $\mathrm{E}$ & $\mathrm{N}$ & $\mathrm{P}$ & $\mathrm{T}$ & 1 & PND \\
\hline 6.2 & $15 / 03$ & $\begin{array}{l}\text { Reorganização dos versos de cantiga } \\
\text { (Com quem você pretende se casar?) }\end{array}$ & $\mathrm{L}$ & D & $\mathrm{R}$ & $\mathrm{CC}$ & 1 & PND \\
\hline $7 a$ & $19 / 03$ & $\begin{array}{l}\text { Escrita de palavras (nomes de } \\
\text { brinquedos) a partir de consulta em } \\
\text { bancos de palavras }\end{array}$ & E & $\mathrm{N}$ & P-R & $\mathrm{CC}$ & 1 & PD-PA \\
\hline $7 b$ & $19 / 03$ & $\begin{array}{l}\text { Escrita de palavras (nomes de frutas) a } \\
\text { partir de sílabas desordenadas }\end{array}$ & $E$ & $\mathrm{~N}$ & P-R & $\mathrm{T}$ & D & PD-PA \\
\hline 8 & $20 / 03$ & $\begin{array}{l}\text { Cópia de palavras da rotina a partir de } \\
\text { sílabas isoladas }\end{array}$ & $\mathrm{E}$ & $\mathrm{N}$ & $\mathrm{P}$ & $\mathrm{T}$ & GG & PD-PA \\
\hline
\end{tabular}




\begin{tabular}{|c|c|c|c|c|c|c|c|c|}
\hline 9 & $21 / 03$ & Leitura de uma lista (nomes próprios) & $\mathrm{L}$ & $\mathrm{N}$ & $\mathrm{R}$ & $\mathrm{CC}$ & 1 & PND \\
\hline 9.1 & $21 / 03$ & $\begin{array}{l}\text { Cópia, em ordem alfabética, de nomes } \\
\text { próprios }\end{array}$ & $E$ & $\mathrm{~N}$ & $P$ & $\mathrm{~T}$ & GG & PD-PA \\
\hline 10 & $22 / 03$ & Leitura de poema (Minha escola) & $\mathrm{L}$ & $\mathrm{D}$ & $\mathrm{R}$ & $\mathrm{T}$ & GG & PD-PA \\
\hline 10.1 & $22 / 03$ & $\begin{array}{l}\text { Conversa sobre o que gostam de fazer } \\
\text { na escola }\end{array}$ & $\mathrm{O}$ & $\mathrm{D}$ & $\mathrm{R}$ & $\mathrm{CC}$ & GG & PD-AA \\
\hline 10.2 & $22 / 03$ & $\begin{array}{l}\text { Escrita de palavras (O que gostam de } \\
\text { fazer na escola) }\end{array}$ & $E$ & $\mathrm{~N}$ & $\mathrm{R}$ & $\mathrm{CC}$ & 1 & PND \\
\hline 11 & $26 / 03$ & Leitura de parlenda (Rei, Capitão) & $\mathrm{L}$ & $\mathrm{D}$ & $\mathrm{R}$ & $\mathrm{CC}$ & GG & PD-PA \\
\hline 11.1 & $26 / 03$ & $\begin{array}{l}\text { Cópia de palavras da parlenda Rei, } \\
\text { Capitão }\end{array}$ & $E$ & $\mathrm{~N}$ & $P$ & $\mathrm{~T}$ & 1 & PND \\
\hline $11.2 \mathrm{a}$ & $27 / 03$ & $\begin{array}{l}\text { Escrita de palavras a partir de figuras } \\
\text { (parlenda Rei, Capitão) }\end{array}$ & $E$ & $\mathrm{~N}$ & P-R & $\mathrm{T}$ & $\mathrm{D}$ & PD-PA \\
\hline $11.2 b$ & $27 / 03$ & $\begin{array}{c}\text { Escrita da letra inicial de palavras a } \\
\text { partir de figura (personagens parlenda } \\
\text { Rei, Capitão) }\end{array}$ & $\mathrm{E}$ & $\mathrm{N}$ & P-R & $\mathrm{T}$ & 1 & PD-PA \\
\hline 12 & $29 / 03$ & $\begin{array}{l}\text { Escrita coletiva de texto instrucional } \\
\text { (confecção brinquedo bilboquê) }\end{array}$ & $E$ & $\mathrm{D}$ & P-R & $\mathrm{T}$ & GG & PD-PA \\
\hline 12.1 & $29 / 03$ & $\begin{array}{l}\text { Cópia de texto instrucional (confecção } \\
\text { de bilboquê) }\end{array}$ & $E$ & $\mathrm{~N}$ & $P$ & $\mathrm{~T}$ & 1 & PND \\
\hline 13 & $01 / 04$ & $\begin{array}{l}\text { Escrita coletiva de bilhete (para } \\
\text { descobrir uma cantiga preferida de } \\
\text { outro professor) }\end{array}$ & $E$ & $\mathrm{D}$ & P-R & $\mathrm{T}$ & GG & $P+A$ \\
\hline \multicolumn{4}{|c|}{ Total de atividades observadas } & \multicolumn{5}{|c|}{26} \\
\hline
\end{tabular}

Fonte: elaborado pela pesquisadora. 


\subsection{Língua no $1^{\circ}$ ano}

Ao ponderarmos sobre as afirmações da professora Bianca, parecem-nos oportunas suas considerações acerca da função social da escrita, uma vez que, conforme verificado no capítulo três, diversos estudos (BAKHTIN, 1988; VOLÓCHINOV, 2017; VIGOTSKI, 2007) demonstram que o indivíduo se constitui na relação com os outros e que, nesse processo, a linguagem tem papel preponderante.

Assim sendo, na escola, as práticas pedagógicas devem se aproximar, ao máximo, da vida social; nesse sentido, dentre diversos autores (COLELLO, 2007, 2011; FERREIRO, 1986; GERALDI, 1997; LERNER, 2002; SOARES, 2008; TEBEROSKY; TOLCHINSKY, 1997), há um consenso de que, desde a alfabetização, é fundamental introduzir as crianças nas culturas do escrito, criando situações didáticas em que se façam presentes as diferentes funções da escrita (tais como auxiliar a memória, fazer registros, organizar o pensamento, permitir a comunicação com pessoas ausentes etc.), os comportamentos leitores e escritores, os diferentes propósitos, as especificidades dos interlocutores e os suportes das situações comunicativas. Do mesmo modo, indissociável ao letramento, é preciso que a criança compreenda a organização e o funcionamento do sistema de escrita.

Contudo, apesar de assumir que a língua constitui uma prática social, ao propor aos alunos o trabalho com a escrita, Bianca se distancia desse princípio, conforme foi possível observar pelos aspectos complementares e indissociáveis destacados nas práticas pedagógicas, que apontam para a:

\section{a) A valorização da escrita como prática social}

Durante a entrevista, Bianca afirma que o desejo de aprender a língua está vinculado ao sentido que a criança constrói sobre as práticas sociais de escrita. Observamos, contudo, que as atividades propostas por ela estão fundamentadas, implicitamente, no pressuposto de que a escrita escolar deve promover exercícios para se aprender a escrever - e não para aprender escrevendo.

As tarefas propostas aos alunos, distanciadas da introdução às culturas do escrito, em sua maioria, não se aproximavam de práticas sociais de uso; pelo contrário, enfatizavam a aprendizagem do sistema de escrita com um fim em si 
mesmo, sem evidenciar situações ou propósitos comunicativos, de modo a não ficar evidente para que ou para quem os alunos deveriam escrever.

Os alunos, ao serem convocados para a realização das tarefas de escrita, deveriam estar atentos prioritariamente "ao que e como" escrever, ocupando-se de seguir a orientação da professora, a qual estava situada como destinatário final das escritas, que eram produzidas com a finalidade de serem por ela corrigidas.

\section{b) A valorização da escrita como meio de comunicação}

Bianca destaca também a função comunicativa da escrita, e afirma sua relevância na relação humana, uma concepção que está de acordo com a perspectiva teórica assumida no presente trabalho, qual seja, de Vigotski $(2007,2008)$, Bakhtin (1988) e Oliveira (1997), segundo a qual o homem produz cultura por meio da construção compartilhada de sentidos e significados e nas relações que estabelece com e pela linguagem.

Entendendo a conversação e o diálogo como formas de encontro, defendemos o potencial da palavra - oral e escrita - de aproximar pessoas na situação de interlocução.

A esse respeito, Cavalcante (2020) esclarece que toda situação comunicativa ocorre entre sujeitos com conhecimentos diversos (culturais, sociais, linguísticos, ideológicos), além de valores e crenças, que permeiam as situações comunicativas e se concretizam em função de determinados propósitos, com base em um gênero discursivo nos diferentes contextos sócio históricos.

$\mathrm{Na}$ vida cotidiana, vivemos diferentes modos de comunicação, que se alteram ao longo do tempo, enquanto igualmente nos modificam. Lembramos, a título de exemplo, as profundas mudanças socioculturais que a comunicação escrita vem sofrendo com as mídias digitais, as quais também modificam nossa forma de estabelecer comunicação e viver relações.

\section{c) Valorização da escrita em detrimento de outras práticas de linguagem}

De acordo com o quadro-síntese que apresenta as atividades observadas nas aulas de Língua Portuguesa, é possível notarmos a prevalência da escrita sobre outras práticas linguísticas. 
Gráfico 6 - Distribuição das práticas de linguagem

\section{Práticas de Linguagem}

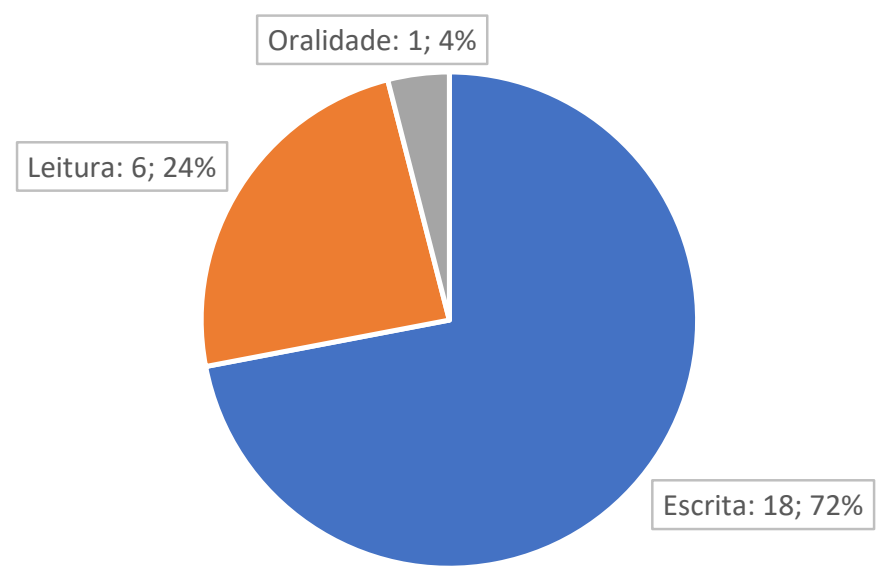

Fonte: elaborado pela pesquisadora

A escola, ao privilegiar uma prática de linguagem em detrimento de outras, deixa de investir no desenvolvimento de habilidades complementares, que, juntas, permitem o uso competente da língua nas diferentes demandas da vida. Isso porque

A relação entre a oralidade e a escrita é compreendida em forma de um continuum das práticas sociais de produção textual (oral e escrita) e não como se concebia tradicionalmente, dicotomizando as duas práticas discursivas (MARCUSCHI, 2008, p. 22)

Assim, tal como já postulado pelos PCNs (BRASIL, 1997), BNCC (BRASIL, 2017) e Currículo da Cidade (SÃO PAULO, 2018), cabe à escola promover práticas planejadas, nas quais os alunos possam vivenciar a fala e a escuta, tanto quanto a escrita e a leitura, produzindo e compreendendo textos sob diferentes modalidades de linguagem.

Além disso, privilegiar a escrita em detrimento de outras modalidades da língua reflete uma postura ideológica elitista, visto que pressupõe a supremacia do mais formal sobre as práticas informais cotidianas, como se estas não merecessem um lugar legítimo na cultura linguística. Em outras palavras, pressupõe uma hierarquia entre as possibilidades do dizer ao invés de admitir a natureza plural da língua. 


\subsection{Ensino e aprendizagem no $1^{\circ}$ ano}

Apesar de, no âmbito discursivo, Bianca declarar que valoriza as necessidades de aprendizagem dos alunos, na esfera prática, foi possível observar outros indícios que parecem nortear as propostas de escrita em um sentido diferente. Assim, considerando as concepções que assume e aquelas que aparecem implicitamente no trabalho com a língua, destacamos os seguintes aspectos:

\section{a) Fragilidade na articulação entre afetividade e cognição}

Ao revelar uma concepção integradora, na entrevista, Bianca traz como consideração importante uma ponderação que evidencia o lugar da afetividade na relação com o conhecimento. ${ }^{33}$

Ao enfatizar o desejo, aponta para a necessidade de um ensino que não dissocie o racional e o emocional, uma vez que aquele que aprende traz, em si, uma integralidade e completude que não devem ser ignoradas por quem ensina.

De fato, sua concepção original ficou reduzida na prática, já que sua preocupação com a afetividade se encontrava restrita ao relacionamento pessoal, pouco incluindo o objeto de conhecimento, no caso, a escrita. Desse modo, o prazer em descobrir - bem como a energia e o empenho necessários à construção de conhecimentos - não apareciam como valores em si.

O domínio e a valorização da escrita como instrumentos que potencializam a relação com o mundo também não se fizeram presentes, o que reverberava entre os alunos, que, sem perceberem o sentido das propostas de trabalho, optavam, sempre que possível, por escrever o mínimo necessário.

${ }^{33}$ Nesse sentido, Vigotski apontava para o lugar da afetividade na constituição do ser humano, uma pessoa como um todo, organizada sistemicamente pela articulação de dimensões diferentes, como mente/alma, corpo/alma, pensamento/linguagem. Wallon (1879-1962), igualmente entendia que o homem deve ser visto em sua completude, considerando-se as dimensões cognitiva, afetiva e motora. Segundo ele, o ser humano traz a afetividade em sua origem, que se diferencia, lentamente, da vida racional, mas nunca dela se dissocia; desse modo, há reciprocidade entre os dois desenvolvimentos, e as aquisições de cada um repercutem permanentemente sobre o outro. (LA TAILLE; OLIVEIRA; DANTAS, 1992). 


\section{b) Distanciamento da escrita como efetiva prática social}

Ao apontar que o desejo de aprender a língua está relacionado à compreensão dos usos sociais da escrita, a professora retoma o letramento como processo concomitantemente à compreensão do funcionamento do sistema alfabético (conforme descrito no capítulo três), processo este que, na escola, deve ocorrer por meio de práticas de escrita que se aproximem, ao máximo, das práticas sociais reais de uso da língua.

No entanto, as atividades de língua observadas em sala de aula mostraram-se artificiais e pouco relacionadas às funções sociais da língua; pelo contrário, tal como ilustra o exemplo da Figura 16, a seguir, eram tarefas fundamentadas na aprendizagem da mecânica da escrita, e não em seus usos sob diferentes contextos e situações comunicativas.

Figura 16 - Atividade 2

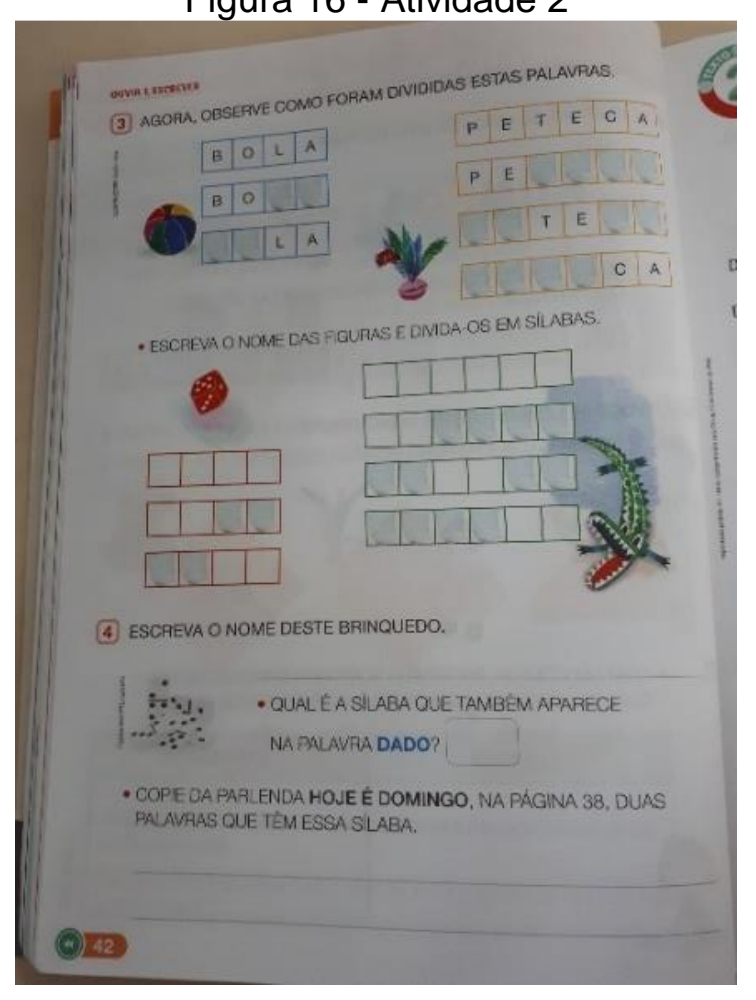

\section{c) Fragilidade na abordagem integrada dos contextos linguísticos}

Em oposição à concepção assumida na entrevista, qual seja, de valorização da escrita sobre outras modalidades linguísticas, a professora, em certos momentos, busca algumas articulações na proposição das atividades, provavelmente, por ter 
assimilado a diretriz prática de que a leitura e a oralidade podem, com efeito, contribuir para a contextualização da escrita.

Observamos, em várias situações, a intenção de articulação da escrita a outras dimensões da língua, como quando a professora buscou, por exemplo, vincular a escrita à leitura, como fez nas atividades 5 e $5.1 \mathrm{a} ; 6$ e 6.1 ; 9 e 9.1; 11 e 11.1, 11.2a, 11.2b.

Em outras atividades (10, 10.1, 10.2 e em 12 e 12.1), a escrita foi proposta como um desdobramento da oralidade, de modo a estar relacionada à uma discussão anterior (o que as crianças gostavam de fazer na escola) e a um texto ditado, respectivamente ilustradas pelas Figuras 17 e 18, a seguir:

Figura 17 - Atividade 10

VAMOS RECITAR A POESIA.

" MINHA ESCOLA "

(Jane Enirenes)

QUANDO EU VOU PRA MINHA ESCOLA

TENHO MUITO O QUE FAZER

PULO, BRINCO, FAÇO ARTE

MAS TAMBÉM QUERO APRENDER

MEUS AMIGOS LÁ DA SALA

SÃO PEQUENOS COMO EU

DÃORISADAS, SÃO ALEGRES,

SÃo BACANAS... E OS SEUS?

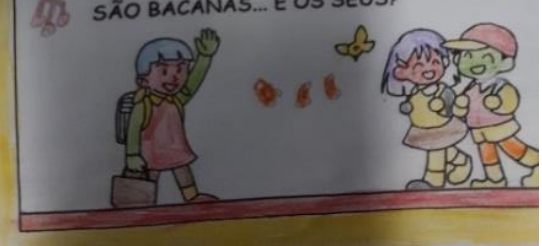

Figura 18 - Atividade 10.2

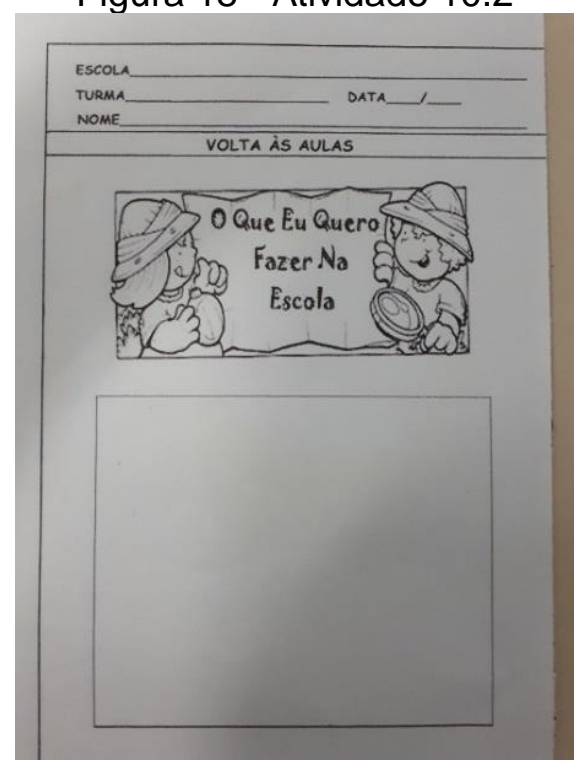

Faz-se importante destacar, contudo, que em ambas as atividades, apesar da relação evidente entre as situações, as manifestações linguísticas (leitura e oralidade) que precediam a escrita constituíram, na verdade, um pretexto para que os alunos se pusessem a escrever, não havendo uma articulação real entre a produção escrita e as situações comunicativas que as geraram.

Os exemplos sugerem que, quando uma diretriz prática é assimilada sem que haja uma base teórica, o fazer pedagógico tende a perder o foco que, a princípio, justificaria a proposição didática. 


\section{d) Fragilidade na exploração e uso dos gêneros textuais}

Durante a observação em sala, foi possível observar que, em alguns momentos, as tarefas de escrita estiveram atreladas a determinados gêneros textuais, entre os quais destacamos as listas e os bilhetes, textos cuja exploração mostrou-se frágil frente ao trabalho priorizado pela professora.

As listas são textos enumerativos, de ampla circulação social, que se organizam em itens, tendo por função apoiar a memória ou elencar uma relação de dados.

No processo de alfabetização, podem ser potentes para gerar investigação e reflexão sobre o sistema alfabético, uma vez que são modelos estáveis de escrita, o que permite aos alunos recorrer a elas para grafar novas palavras. Do mesmo modo, aprender a consultar e analisar palavras escritas pode favorecer sua organização interna e autonomia para se disporem ao trabalho.

No que diz respeito ao papel da lista no processo de aprendizagem, vale lembrar que

Listar significa relacionar nomes de pessoas ou coisas para a
organização de uma ação. [...] Por ter uma estrutura simples, a lista é
um texto privilegiado para o trabalho com alunos que não sabem ler e
escrever convencionalmente, mas é necessário que o professor
proponha a escrita de uma lista que tenha alguma função de uso na
comunidade ou na sala de aula. A escrita de listas de palavras que
começam com a mesma letra ou outras similares são inadequadas,
pois descaracterizam a função social desse texto. [...] (ABREU et al.,
2000, p. 108)

Ao longo do período observado, os alunos tiveram contato com listas diversas vezes: além de estarem presentes na escrita da rotina do dia e na lista de nomes da turma afixada na parede, ocorreram também nas atividades propostas pela professora, como em 1a, 1b, 4, 5.1a, 5.1b, 7b, 8, 9.1, 10.2 e 11.2a.

Apesar de tão frequentes, as listas não pareciam pertencer a um gênero familiar às crianças, que não tinham muita clareza sobre a sua estrutura, bem como não as tinham como referência para refletir sobre a língua. Desse modo, na maioria das vezes, liam e produziam listas de palavras sem ter claro o que faziam, bem como sem entenderem com que propósitos e em que situações comunicativas o faziam.

A respeito da lista com nomes próprios, Ferreiro $(1989,2001 b, 2013)$ afirma a relevância de compreendê-los como marcas identitárias e fonte de conflitos cognitivos 
importantes, que permitem à criança elaborar e reelaborar hipóteses, construindo conhecimentos sobre o sistema de escrita.

Não me canso de insistir na importância que tem o nome próprio. Aprender a ser a gente mesmo, por escrito, é algo absolutamente insubstituível. [...] O "ser por escrito" é uma descoberta absolutamente sensacional, que é própria e singular. [...] ( $\mathrm{O}$ trabalho com os nomes), entre outras coisas, ajuda a reconhecer que a ordem das letras no interior de uma palavra não é aleatória e que a primeira tem um valor de indicador fundamental para o restante. [...] (O nome próprio) é também fonte de informação sobre as próprias letras [...] (que) permite ter uma espécie de abecedário básico, com o qual algumas crianças conseguem escrever quase tudo, utilizando as letras de seu nome, mas em outra ordem. (FERREIRO, 2001b, p. 81)

A esse respeito, destacamos a atividade 9.1, ilustrada na Figura 19, a seguir; nessa proposta os alunos deveriam copiar uma lista de nomes próprios, ordenandoos alfabeticamente. Salientamos que os nomes eram fictícios (não pertenciam ao universo do grupo) e destinavam-se, supostamente, à elaboração de uma agenda, um gênero textual que tampouco foi explorado em classe.

Figura 19 - Atividade 9.1

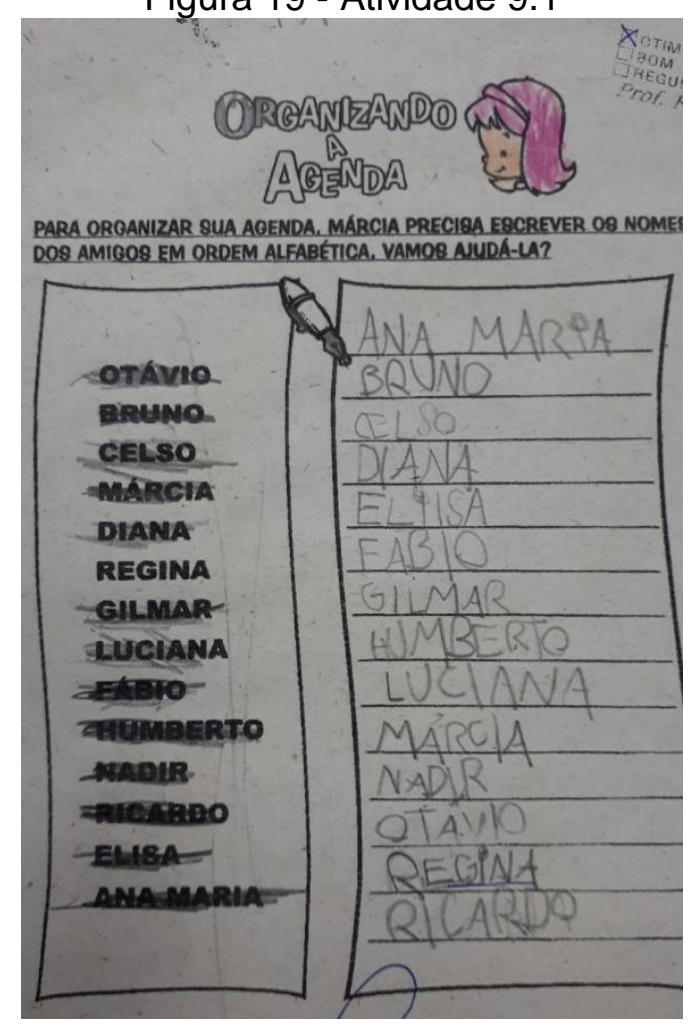


Ao explicar o trabalho com os nomes da turma do primeiro ano, Bianca explica que estes "somente são foco de trabalho no início do ano", tendo ficado para trás há tempo, caso contrário, "o trabalho não anda!". Esclarece que a maioria das crianças já sabe grafar o próprio nome, o que é esperado para este momento da vida escolar. Essa posição dá indícios de que a professora entende o trabalho com nomes com o propósito específico de saber grafá-los, sem considerar o potencial dessas escritas como fonte de consulta ou pelo seu significado de constituição da identidade da turma, razões pelas quais a lista de nomes permanecia na sala como mero adorno

Também as atividades da rotina listadas na lousa poderiam constituir-se em palavras estáveis, fonte de consulta para que os alunos se lançassem à novas escritas. Contudo, quando copiadas mecânica e irrefletidamente pelos alunos, parecem ter a mesma função das demais atividades em que predomina a cópia de palavras, restringindo-se ao treino da escrita. Assim, o texto "lista", desprovido de função social e de função reflexiva, passou a se constituir como um mero exercício de grafar palavras.

Além das listas, em nossa vida cotidiana, diversos gêneros nos permitem a comunicação com os demais, seja para informar ou para compartilhar ideias, sentimentos e experiências e podem contribuir para fortalecer o processo de letramento mesmo no caso de crianças que não saibam escrever de modo convencional e autônomo (nesse caso, tendo a professora como escriba). A esse respeito, Abreu et al. (2000) esclarecem que a produção de cartas e de bilhetes é importante já na alfabetização e desde que preservem a função comunicativa para efetivos interlocutores.

Enfatizam, igualmente, como é relevante que todos os alunos conheçam o conteúdo da mensagem a ser abordado, além de terem a oportunidade de refletir sobre a escrita e a organização textual, o que favorece aprendizagens sobre o sistema articuladas à situação, aos propósitos comunicativos e aos interlocutores.

Bianca lança mão desse gênero na atividade 13, quando os alunos foram convidados a produzir um bilhete fictício para descobrir a cantiga preferida de outro professor, como se vê no exemplo que se segue: 
Figura 20 - Atividade 13

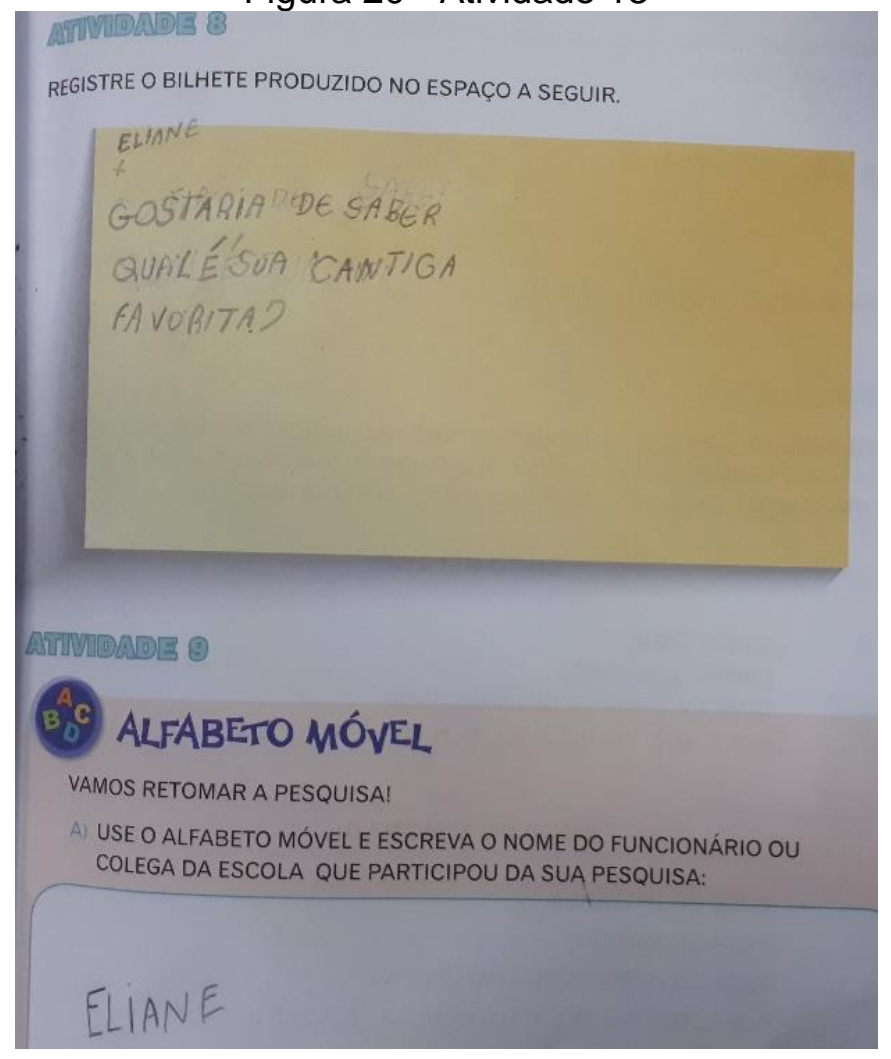

Essa proposta chamou nossa atenção, uma vez que, ao invés de ser destinado a um interlocutor ausente (como é o mais típico na escrita que se justifica pelo formato desse gênero), o bilhete foi escrito para a professora estagiária em sua presença, o que artificializou o propósito comunicativo desde a origem da atividade. Além disso, antes da produção, não houve um momento de planejamento compartilhado, em que as crianças pudessem refletir e organizar o conteúdo da mensagem, sequer socializar ideias sobre o que e como poderiam dizer.

Finalmente, por ser uma produção coletiva, em que a professora era escriba da turma, entendemos que a voz dos alunos deveria estar ali presente, enquanto ditavam o texto ao professor.

Observamos, contudo, que ao escrever, Bianca induzia as crianças na escolha do que e como dizer, assim como alterava palavras e a construção gramatical, traindo a construção original dos alunos sem qualquer reflexão. Em outras palavras, grande parte do texto acabou sendo uma produção da professora. Tais encaminhamentos intervieram nas possibilidades de as crianças planejarem e revisarem o texto, de modo a compreenderem sua estrutura e organização, o que tornou frágil a exploração do gênero. 


\section{e) Professor como centro do processo educativo}

Ao longo da observação, verificamos que Bianca parecia ter ciência de que a gestão dos processos de ensino e aprendizagem é de responsabilidade docente; desse modo, ela ocupava um lugar de referência no grupo: planejava e conduzia o trabalho, definindo o que e como os alunos trabalhariam, além de orientá-los a cada momento.

Porém, sua prática apontava, implicitamente, para uma concepção de aprendizagem guiada pela diretividade do professor, que, como sujeito detentor do conhecimento, determina conteúdos, sustenta metodologias e elabora mecanismos de controle da aprendizagem independentemente dos saberes, das potências e demandas discentes.

Essa constatação corrobora a constatação de outros pesquisadores, como Weisz e Sanchez (2002, p. 32) que, na análise de práticas docentes afirmavam já no começo desse século: "o discurso era construtivista, mas a prática era - às claras ou disfarçadamente - empirista".

Alguns indícios revelavam essa visão na turma de Bianca, como por exemplo, o fato de os alunos quase sempre estarem sentados em fileiras, e de frente para a lousa e para Bianca. Cabia-Ihes, como evidente expectativa docente, ouvir com atenção tudo o que ela dizia e, posteriormente, seguir suas orientações para a execução das atividades a serem entregues.

Pouco engajados com a própria aprendizagem, os alunos seguiam a rotina diária dirigindo-se constantemente à professora para lhe fazer perguntas que tratavam de confirmar se o que estavam a fazer era, ou não, o esperado, assim como pediam orientação de como proceder para executar as tarefas, passo a passo. Com parcas iniciativas, demonstravam pouco protagonismo e disposição para escrever por si mesmos, bem como para participar das aulas socializando ideias. 


\section{f) Pouca clareza sobre as necessidades de aprendizagem dos alunos}

Preocupada com o "bem ensinar", Bianca parecia ter noção dos objetivos a serem alcançados. Contudo, apesar de afirmar que a aprendizagem está ancorada na construção cognitiva, deixa implícita no processo de ensino a desarticulação entre o que entende ser importante ensinar, os saberes e as necessidades de aprendizagem dos alunos, que se encontravam em diferentes níveis de conceitualização da escrita.

A esse respeito, vale mencionar a crítica feita por Weisz e Sanchez (2002, p. 42), que apontam:

Se o professor não sabe nada sobre o que o aluno pensa a respeito do conteúdo que quer que ele aprenda, o ensino que oferece não tem "com que dialogar". Restará a ele atuar como numa brincadeira de cabra-cega, tateando e fazendo sua parte, na esperança de que 0 outro faça a dele: aprenda. (WEISZ; SANCHEZ, 2002, p. 42)

A constatação desse descompasso torna-se evidente tanto na ocasião das atividades de avaliação, quanto na correção das tarefas de escrita, que igualmente ofereciam poucos indícios capazes de promover alterações no planejamento docente, já definido a priori.

Diversas vezes todos realizaram as mesmas propostas, independentemente de quais conjecturas sustentavam seus processos reflexivos; e poucas foram as situações observadas em que as crianças puderam colocar em jogo o que sabiam para poder resolver problemas reais vinculados à aprendizagem da língua.

De fato, apenas nas propostas 1a (ilustrada na Figura 21, a seguir), $10.2 \mathrm{e}$ $11.2 \mathrm{a}$ as crianças puderam, a partir de seus conhecimentos prévios, elaborar e reelaborar hipóteses ao refletirem sobre a língua.

Contudo, isso não ocorreu, necessariamente, pois as intervenções docentes limitaram-se a orientar a execução da tarefa em si, de maneira que não ofereceram subsídios outros (como por exemplo, procedimentos de consulta aos nomes da turma) que pudessem promover avanços cognitivos. 
Figura 21 - Atividade 1a

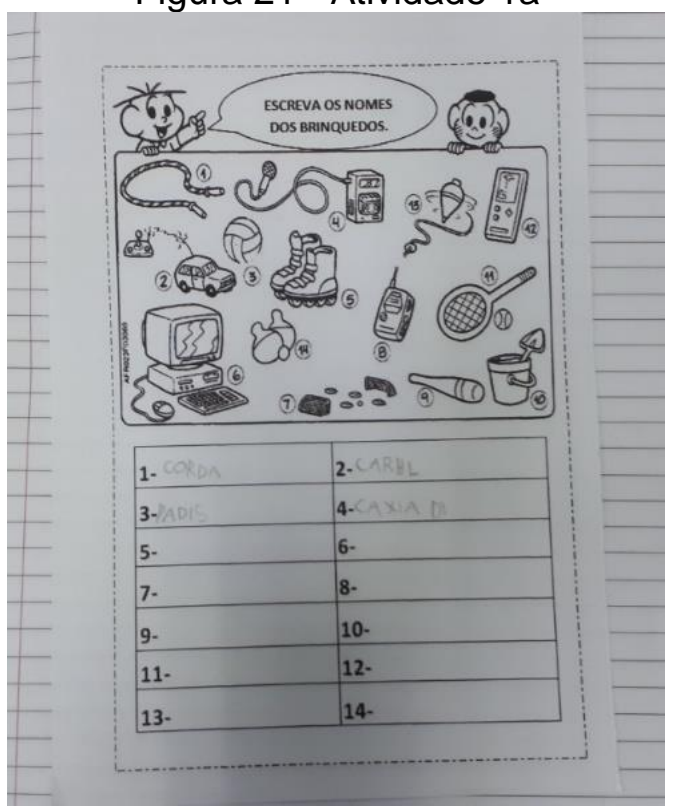

Observamos também que, apesar de declarar que o ensino deve partir das necessidades de aprendizagem do aluno, na prática, essa preocupação tendia a se perder. Foi o que ocorreu, por exemplo, nas atividades diversificadas apresentadas a seguir, nas Figuras 22 e 23, em que alunos silábico-alfabéticos e alfabéticos deveriam copiar palavras de uma parlenda, enquanto alunos pré-silábicos deveriam ordenar sílabas para compor palavras.

Figura 22 - Atividade 5.1a

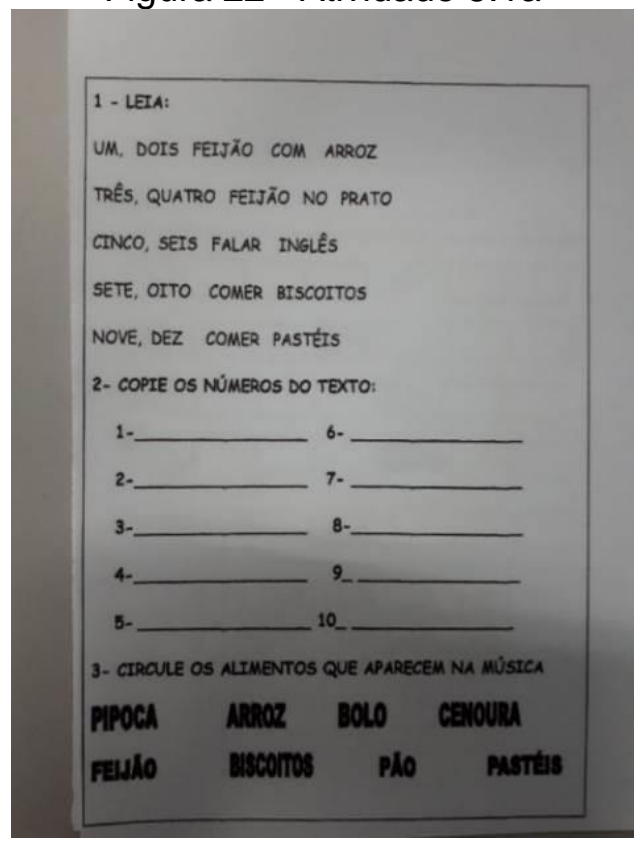

Figura 23 - Atividade 5.1b

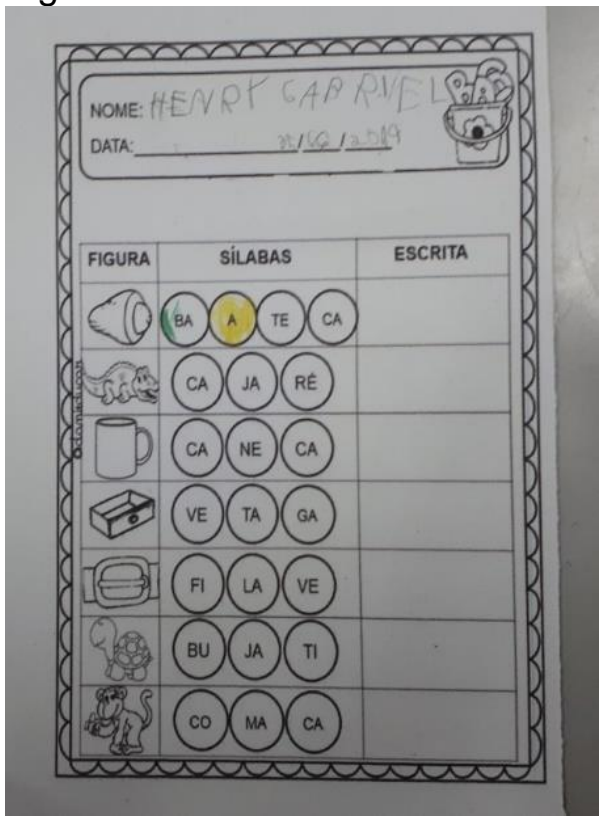




\title{
g) Ênfase nos aspectos notacionais da escrita
}

Considerando, especificamente, as atividades de escrita observadas, em relação às dimensões linguísticas, verificamos que $100 \%$ das atividades propostas referiam-se a aspectos notacionais, predominando tarefas associadas às características da representação gráfica da linguagem, mais especificamente, ao sistema de representação convencional da escrita alfabética.

\begin{abstract}
É interessante notar que a natureza essencialmente comunicativa da linguagem nos leva a esperar exatamente o oposto: eventos de letramento associados a formas criativas e prazerosas de interação. Nota-se, assim, um desvio: a ausência de dialogia nas atividades de leitura e escrita tipicamente escolares. Isso tira da maioria das atividades de uso da língua escrita na escola a sua essência comunicativa, de abertura ao novo, das possibilidades criativas mais ricas. Trata-se, efetivamente, da supremacia da "escrita represada" sobre a "escrita libertadora". (TEIXEIRA, 2011, p. 98)
\end{abstract}

Assim, o aprender a escrever prevalece nas dezoito atividades de escrita observadas: em seis delas, as crianças deveriam escrever tendo por base as sílabas (1b, 2, 3, 5.1b, 7b, 8); e, em quatro delas, o que orientava a escrita eram as letras. Nestas, o foco se alterava, havendo ênfase ora na ordem alfabética $(6.1,9.1)$, ora na letra inicial (11.2b) e ora na mudança de sentido do escrito pela alteração das letras que compunham as palavras (4). Exemplos disso podem ser comprovados pelas atividades que se seguem, representadas pelas Figuras 24 e 25: 
Figura 24 - Atividade 1b

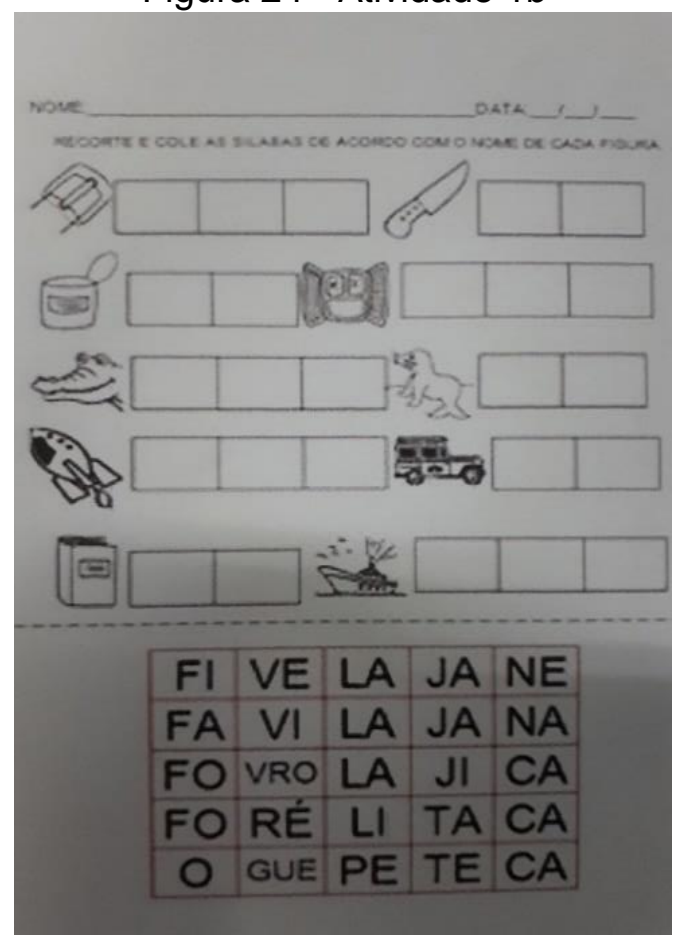

Figura 25 - Atividade 11.2b

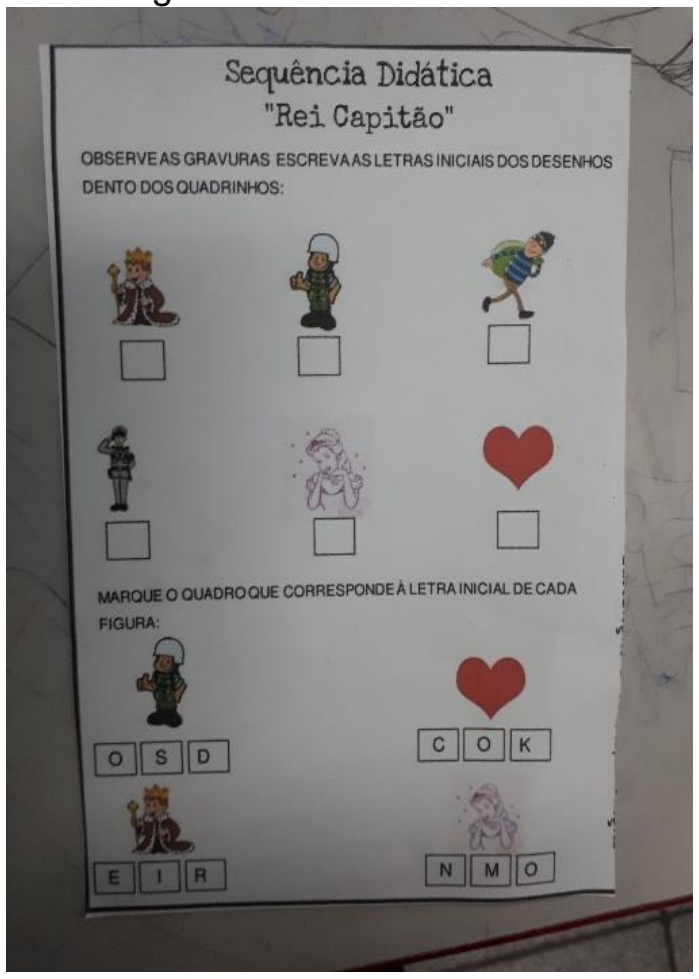

$\mathrm{Na}$ atividade $5.1 \mathrm{a}$, as crianças procederam diretamente à cópia de palavras, tendo por base uma parlenda lida e memorizada anteriormente. A cópia de um texto também se fez presente (12.1), e os alunos foram chamados a observar a escrita correta das palavras, devendo conferir o próprio escrito com o texto referência, grafado na lousa pela professora.

Como já dissemos, apenas três atividades propunham aos alunos escrever espontaneamente, isto é, segundo as próprias hipóteses (1a, 10.2, 11.2a); nesta última, porém, o processo reflexivo esteve relativizado, visto que as crianças já conheciam de memória a escrita das palavras em questão.

Vale destacar aqui as atividades 12 e 12.1, nas quais os alunos deveriam ditar um texto instrucional à professora. Nesse contexto, especialmente, a reflexão sobre os aspectos discursivos da língua foi garantida, uma vez que teriam que se ocupar de pensar sobre o que dizer e como fazê-lo por escrito.

No entanto, ao longo da proposta, foi possível observar que o que foi escrito pela professora não era exatamente aquilo ditado pelos alunos, pois, ao escrever, ela fazia correções gramaticais e sintáticas, sem compartilhar as alterações junto aos ditantes. Os alunos, que posteriormente copiaram a escrita da professora, não tinham clareza sobre os acertos feitos. 


\section{h) Foco na correção das tarefas}

Durante a observação das práticas de escrita, verificamos um pressuposto subjacente às propostas de escrita da professora aos alunos: o propósito das atividades de escrita era ensinar a escrever - e a escrever corretamente.

Constituindo tarefas com finalidade em si mesmas, estas deveriam sempre ser corrigidas na lousa, pela professora, e posteriormente retificadas pelos alunos, até que o resultado de cada um, em seus respectivos cadernos, ficasse correto. Desse modo, também se justificava a preocupação implícita de que o resultado da atividade é mais importante do que os processos reflexivos que ela pode desencadear, tendo o aluno, então, que se ocupar em conferir, sem questionar, seus acertos e enganos em relação aos modelos corretos oferecidos por Bianca. Ora,

Quando o professor desconsidera o esforço de seu aluno, dizendo apenas que o que ele fez não está correto, sem lhe devolver uma questão, algo sobre o que pensar, acaba, mesmo sem querer, desvalorizando sua tentativa, seu esforço. E, se cada investimento que o aluno fizer não tiver seu valor reconhecido, ele provavelmente vai acabar pensando duas vezes antes de investir de novo. (WEISZ; SANCHEZ, 2002, p. 40-41)

Foi o que observamos nas atividades de escrita espontânea, quando vários alunos receavam se enganarem e, desestimulados, não se arriscavam a escrever segundo as próprias hipóteses, preferindo copiar de um colega ou o que a professora havia grafado na lousa. A atividade da Figura 26, a seguir, exemplifica tal situação e revela como o processo reflexivo sobre a escrita fica preterido em relação à escrita correta, isto é, a do professor: 
Figura 26 - Atividade $11.2 \mathrm{a}$

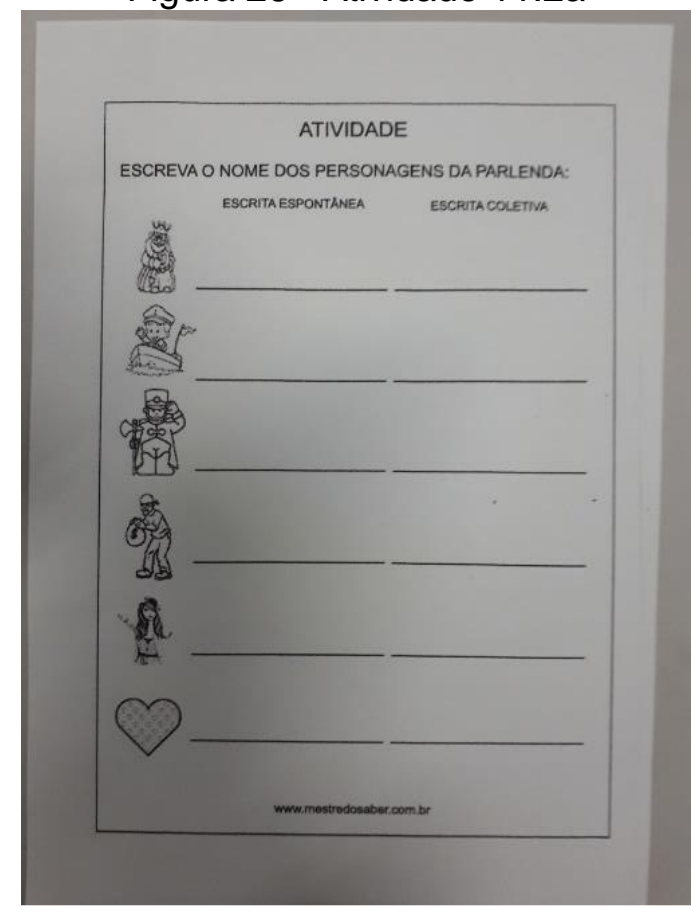

A esse respeito, vale mencionar que observamos a cristalização de lugares entre as crianças, que sabiam, de antemão, quem eram os alunos "mais e menos sabidos"; eram frequentes os comentários espontâneos, em que alunos e a professora manifestavam a importância de acertar, de ser um bom aluno por cometer poucos erros.

\section{i) Ênfase na aprendizagem pela repetição e memorização}

Ao partir do princípio de que os alunos aprendem mais e melhor pela recorrência de práticas que os ajudam a reter "o correto", durante a entrevista, Bianca explicita uma concepção de ensino prescritivo, sustentado no planejamento de contextos que favoreceriam a percepção e a fixação do objeto de conhecimento, neste caso, a escrita.

Assim, segundo Bianca, boas situações de aprendizagem precisam ser repetidas, o que ela confirma ao apontar a importância das rotinas criadas pelo professor, as quais estão pautadas na repetição, de "mais do mesmo", até que o aluno possa aprender pela memorização do correto (a relação fonema-grafema).

Embora Bianca afirme não valorizar a cópia como estratégia de ensino, durante a observação, verificamos a existência desse tipo de atividade como recurso de fixação; a cópia, ora era diretamente solicitada pela tarefa em si, ora não, ficando 
subjacente ao processo de correção, momento em que os alunos deveriam apagar o que haviam grafado equivocadamente, copiando a escrita da professora.

\begin{abstract}
A esse respeito, é preciso deixar claro que o problema não está na cópia, mas, uma vez mais, na precária consciência dos critérios que sustentam as práticas escolares. Tomados pela superficialidade dos "modismos pedagógicos", muitos professores tendem a centrar sua atenção nas atividades em si, aceitando-as ou rejeitando-as em bloco, sem perceber os princípios que as subsidiam nem as possibilidades de uso que condicionam a legitimidade e a coerência do fazer pedagógico. (COLELLO, 2007, p. 129)
\end{abstract}

Observamos, também, a repetição na escrita diária do cabeçalho e da rotina do dia, atividades defendidas e justificadas pela professora - sob o pretexto de permitir que os alunos se situem na dinâmica de trabalho - como uma forma de treinarem a escrita correta.

\title{
j) Abordagem da consciência fonológica pela relação grafema-fonema
}

Ao definir como se aprende a língua, Bianca enfatiza a percepção e a discriminação fonêmica, bem como sua correta relação com a grafia das letras, como bases para a alfabetização; sua concepção, a qual subentende a aprendizagem da escrita pelos processos de codificação e decodificação, incorpora uma postura já criticada por Paulo Freire (1921-1997) ainda no século passado:

[...] Sempre vi a alfabetização [...] como um ato político e um ato de conhecimento, por isso mesmo, como um trabalho criador. Para mim, seria impossível engajar-me em um trabalho de memorização mecânica dos ba-be-bi-bo-bu, dos la-le-li-lo-lu... Daí que também não pudesse reduzir a alfabetização ao ensino puro das palavras, das sílabas ou das letras. (FREIRE, 1983, p. 21)

A professora, acreditando que o conhecimento vem do objeto (neste caso, a pauta sonora que constitui a língua falada), percebido por meio dos sentidos, procura planejar e encaminhar o processo de ensino da língua por uma lógica, sob a ótica docente, que caminha "do mais fácil ao mais difícil", o que corresponderia à exploração primeira das letras, depois das sílabas, palavras e textos, respectivamente.

Pudemos constatar essa dinâmica também ao longo das observações em classe, e não só durante a entrevista, quando a professora explicou que gostaria de trabalhar mais a partir de textos, como parlendas e cantigas, mas que não poderia fazê-lo até que todos os alunos estivessem alfabéticos. 
A mesma concepção fica evidente quando Bianca comenta ter recebido, no início do ano, uma turma com muitas crianças pré-silábicas, o que a obrigou a iniciar o processo de alfabetização pela exploração do alfabeto, focando posteriormente na formação das sílabas e, em seguida, no trabalho com os nomes próprios da turma, atualmente, não mais foco de trabalho em classe. Assim, ao trabalhar com textos, ainda nos dias de hoje investe na identificação de palavras específicas para que os alunos aprendam a ler, uma vez que, em sua visão, ler palavras é mais simples do que ler textos.

\section{k) Distanciamento de uma perspectiva de aprendizagem reflexiva}

Embora, na entrevista, Bianca assuma que os alunos também aprendem por construção cognitiva, foi possível observar que, no âmbito prático, o que sustenta sua prática cotidiana parece ser o pressuposto de que o aluno, que não sabe, absorve o conhecimento de fora para dentro, ou seja, em uma atitude passiva de aprendizagem.

Nesse sentido, Bianca revela a crença de que, sem o professor, a criança não é capaz de refletir sozinha, o que confirma o princípio de que não tem condição de saber se não for informada por um outro. Desse modo, muitas vezes, seu esforço para transmitir conhecimentos desconsidera tanto a compreensão do aluno quanto suas possibilidades de reflexão.

Durante a observação das práticas, pudemos notar uma desarticulação entre as perspectivas de aprendizagem e de ensino, já que prevaleceram atividades de escrita destinadas a um aluno passivo, enquanto o professor assume o papel de transmissor de conhecimentos. Em contrapartida a esse tipo de ocorrência, vale ressaltar o construtivismo como

\footnotetext{
Uma situação problema (que) se define sempre em relação ao aprendiz. Deve ser uma situação na qual a solução não vá ser buscada na memória, nem a resposta possa ser imediata, pois o aluno precisará mobilizar conhecimentos que já tem e usá-los de tal forma que acabará construindo uma solução não previamente determinada. (WEISZ; SANCHEZ, 2002, p. 36-37)
}

Observamos também a existência de atividades que, a princípio, poderiam provocar algum nível de reflexão sobre a língua, mas, em decorrência de sua condução e pela qualidade das intervenções docentes, remeteram à passividade do aluno, como por exemplo, nos casos em que deveriam repetir informações. 
Assim, o Quadro 15, a seguir, procura fazer o cruzamento entre as perspectivas de aprendizagem contempladas em aula e os processos de ensino que efetivamente ocorreram.

Quadro 15 - Perspectivas de Ensino e de Aprendizagem - $1^{\circ}$ ano
\begin{tabular}{|c|c|c|c|}
\hline & $\begin{array}{c}\text { Ensino pautado pela } \\
\text { Construção Cognitiva }\end{array}$ & $\begin{array}{c}\text { Ensino pautado pela } \\
\text { Transmissão de saberes }\end{array}$ & \\
\hline $\begin{array}{c}\text { Aprendizagem } \\
\text { Reflexiva }\end{array}$ & 2 & 0 & \multirow{2}{*}{$\begin{array}{c}\text { Total de } \\
\text { atividades }\end{array}$} \\
\cline { 1 - 3 } Aprendizagem Passiva & 0 & 7 & \\
\hline $\begin{array}{c}\text { Aprendizagem Passivo- } \\
\text { Reflexiva }\end{array}$ & 1 & 8 & 18 \\
\hline
\end{tabular}

Fonte: elaborado pela pesquisadora

\section{l) Preocupação com o controle do ensino em função da aprendizagem}

\section{dos alunos}

Preocupada com a assimilação de informações por parte dos alunos, Bianca permanecia próxima a eles e se dedicava à tentativa de guiar seu processo reflexivo. Assim, na intenção de controlar o que aprendiam, fazia-lhes perguntas indutivas, esperando que as respostas correspondessem ao que ela havia ensinado.

Do mesmo modo, acompanhava-os, passo a passo, na realização das atividades, corrigindo-os e orientando-os, declarando o que entendia que deveriam saber.

Assim como nas situações cotidianas de controle da aprendizagem, a concepção implícita de Bianca sobre a necessidade de "conduzir esse processo", a longo prazo, por um percurso linear e pré-determinado, transpareceu em sua fala sobre um planejamento que se pauta por momentos de ensino que vão sendo progressivamente superados (primeiro trabalhar com as letras, depois com os nomes próprios, a seguir com as sílabas etc.). Nesse caso, o que se observa é a desconsideração de especificidades e da pluralidade das frentes cognitivas que se entrelaçam na construção da língua escrita. 
A esse respeito, Colello (2014, p. 181), levando em conta a amplitude e a complexidade dos processos de aprendizagem, questiona a pretensão de controle implícita em muitas práticas de alfabetização:

[...] o sujeito que lê ou escreve deve considerar diferentes pontos de vista, na busca de garantir ou ajustar a sua produção ou de interpretar um texto, relacionando-a aos propósitos, contextos ou interlocutores. Como fios de uma teia que se entretece de modo singular, as diversas frentes de processamento cognitivo em cada aluno ${ }^{34}$ se cruzam ou se afastam; avançam ou resistem; complementam-se, fortalecendo novas estratégias; ou trombam, fazendo emergir contradições e talvez a necessidade de novas tessituras em um significativo processo de fazer e refazer. Em cada caso, a alfabetização merece ser vista como um bordado artesanal, único e sem receitas, já que não se pode controlar os inúmeros percursos do sujeito aprendiz.

\section{m) Preocupação com o controle da disciplina}

No âmbito discursivo, Bianca esclarece que cabe ao professor controlar e garantir a disciplina, a fim de evitar distrações por parte dos alunos.

Tal concepção foi observada pela pesquisadora durante o período em que esteve em classe, momento em que verificou a preocupação constante da professora em evitar que os alunos perdessem o que era dito por ela, exigindo que se mantivessem sentados e não conversassem entre si enquanto trabalhavam.

Observa-se aqui uma concepção subjacente à ação docente: a de que a aprendizagem é incompatível com a disciplina, o que suscita um questionamento: sob essa ótica, de que disciplina estamos falando? Ao que parece, o princípio implícito aqui compreende por "disciplina" a passividade e a submissão frente à autoridade docente, e não a organização para o trabalho, como deveríamos supor.

Entendemos que essa perspectiva tende a ir de encontro a uma visão emancipatória, na qual o aluno é sujeito e aprende a regular sua atuação pautada em valores. A esse respeito, Tognetta (2001, p. 169) esclarece que

$\mathrm{Na}$ comunidade, as regras e todo o trabalho devem ser formulados pelos seus membros; portanto, crianças e professora têm papel fundamental haja vista que a disciplina é orientada pelo respeito, e não, pela obediência cega. O professor é autoridade, sabe onde quer

${ }^{34}$ A autora, no referido texto, a título de exemplo (sem a pretensão de esgotar o tema), enumera e descreve 23 frentes de processamento cognitivo no processo de alfabetização, o que desestabiliza os princípios de um ensino linear, controlado e preconcebido (das letras às sílabas, às palavras, à ortografia, à gramática para se chegar à produção e à interpretação de textos). 
chegar; porém, dá oportunidades para que a criança cresça em suas responsabilidades e participação efetiva. (TOGNETTA, 2001, p. 169)

\section{n) Incompatibilidade entre as perspectivas de aprendizagem e a condução das propostas}

Ao analisarmos as posturas declaradas da professora sobre os processos de ensino e de aprendizagem, notamos uma contradição, uma vez que, se o ensino deve partir das demandas de aprendizagem dos alunos, não pode, ao mesmo tempo, sustentar-se na memorização e repetição.

Ao longo da observação das práticas, no entanto, verificamos que, apesar de Bianca manifestar a intenção de acompanhar os alunos por meio de intervenções produtivas, isto é, que favorecessem processos de reflexão, ela, na maioria das vezes, ocupava-se mais em oferecer-lhes informações corretas e corrigi-los.

Tal dinâmica revela como - embora se ocupe, algumas vezes, de oportunizar situações capazes de promover uma aprendizagem pautada na construção cognitiva - a intervenção pedagógica não garante que isso ocorra, especialmente quando incide sobre mecanismos repetitivos ou de pura memorização.

Nesse sentido, observamos a existência de inconsistência e incoerências entre os objetivos de aprendizagem calcados na construção de conhecimentos por parte do aluno e as práticas de Bianca, as quais se apoiavam em práticas diretivas e transmissivas.

\section{o) Fracasso escolar justificado pelos aspectos extraescolares}

Ao ser questionada sobre as motivações do fracasso escolar, a professora explica, durante a entrevista, que as crianças avançam pouco devido a diferentes razões. Dentre estas, destaca, primeiramente, o grande número de faltas desses alunos na escola, e acrescenta que a pouca participação das famílias interfere também na aprendizagem: por não serem acompanhados em seus processos de aprendizagem pelos responsáveis, os alunos deixam de estudar e de fazer tarefas de casa propostas, de uma a duas vezes por semana, pela professora.

Bianca complementa, ainda, que a escolaridade anterior afeta as condições infantis de avançar nos conhecimentos sobre a escrita. Muitos vêm de Escolas 
Municipais de Educação Infantil sem saber nomear as letras e desconhecendo o alfabeto, o que, segundo ela, atrasa o processo de alfabetização.

$O$ aspecto que chama nossa atenção aqui, assim como em suas declarações, é que está claro para a professora que os problemas enfrentados pelo aluno na escola advêm de fatores externos; logo, não é preciso - nem possível - modificar cenários educativos a fim de resolver o problema.

A mesma concepção foi identificada nas práticas docentes, direcionadas à cobrança, de alunos e famílias, pelo sucesso dos processos de aprendizagem.

\subsection{Interação no $1^{\circ}$ ano}

Bianca, durante a entrevista, ao declarar o modo como compreende o papel das interações no ensino, revela a importância que atribui ao convívio com os alunos, enxergando-o como um fator que favorece a aprendizagem.

De modo consonante, durante a observação em classe, foi possível verificar como se preocupa em estar presente na relação com as crianças, que por ela demonstram apreço e parecem ter na professora uma referência de cuidado e de orientação, ou seja, alguém em quem podem confiar.

Contudo, observamos que suas considerações têm implícitas acepções que intervêm no cotidiano da relação entre professor e alunos, bem como entre os alunos. Trataremos de analisá-las, bem como os princípios que declara, e o faremos destacando a relevância dos seguintes aspectos:

\section{a) Interação como vínculo afetivo}

Ao compreender que o aprendiz constrói conhecimentos não somente a partir da cognição, mas, também, por meio dos processos psicológicos subjacentes (emocionais e motivacionais), Bianca valoriza a afetividade.

Estamos de acordo com a importância de se estabelecer uma interação afetiva de boa qualidade visando oportunizar a aprendizagem. Entretanto, entendemos que o bom vínculo afetivo potencializa e nutre o desejo de aprender quando há confiança mútua e valoração do conhecimento, sem que seja preciso "provar" algo a alguém, como expressou a professora durante a entrevista. 
Pelo contrário, cabe ao docente ser aquele que estimula a descoberta e o prazer em conhecer, de modo a compartilhar ferramentas para que o aluno "aprenda a aprender", com autonomia crescente. Atrelar o desejo de aprender ao sentimento de ter que "mostrar o que se sabe ao professor" aponta para uma concepção que desvia a motivação primeira do ensino, qual seja, a de fomentar a curiosidade em desvendar o mundo. A esse respeito, afirmam Davis e Oliveira (2010):

O bom professor procura fazer com que o processo de aprendizagem
seja motivador em si mesmo: as crianças devem ser levadas a colocar
em jogo toda a sua energia para enfrentar o desafio intelectual que a
escola Ihes coloca. O prazer vem, assim, da própria aprendizagem, do
sentimento de competência pessoal, da segurança de ser hábil para
resolver problemas. (DAVIS; OLIVEIRA, 2010, p. 107)

Além disso, ao considerarmos o "desejo de aprender para mostrar" a outrem, podemos inferir o raciocínio linear do "desejo de mostrar", o que não implica, necessariamente, "aprender" no sentido de construir conhecimento. Assim, devolver ao professor a informação por ele fornecida pareceria suficiente para ser valorizado como aluno, o que nos coloca a questão: será mesmo disso que se trata?

Diante do exposto, é preciso ir além da visão de relevância das interações pelo afeto e colocar em pauta o papel formativo que estas assumem quando há, na classe, uma rede de participações, em que os indivíduos se consideram, reciprocamente, interlocutores que constroem o conhecimento pelo diálogo. É tarefa docente garantir condições e intencionalmente oportunizar situações, a fim de que todos trabalhem em cooperação e colaboração, a partir da comunicação produtiva.

\section{b) Interação por competição}

Bianca aponta a competição entre os alunos como fator de estímulo à aprendizagem e esclarece que tal fato ocorre porque "crianças dessa idade são naturalmente competitivas".

Considerando essa visão sob um contexto mais amplo, é importante lembrar que vivemos em uma sociedade fundamentada na rivalidade, na disputa e na valorização do êxito, o que nos conduz diretamente à distinção por desempenho e resultado das ações, e, em consequência, à desvalorização dos processos. Contrapondo-se a essa postura, Mauri (2006, p. 106) afirma que "a construção do conhecimento conceitual não se faz contra os outros, mas com os outros (poder sentir- 
se bem perguntado e sendo perguntado, resolvendo dúvidas e ajudando a outros a realizar a mesma tarefa etc.)".

Esse argumento permite desmistificar essa questão da "natureza competitiva" das crianças, uma vez que estão inseridas no contexto da cultura. Igualmente, permite avançar na compreensão do tema quando retomamos o papel da escola como um lugar de contraponto e de ampliação de perspectivas de leituras de mundo, bem como de resistência ao que vai de encontro à desumanização, de modo a contribuir para a meta de uma sociedade mais justa e igualitária.

Nesse sentido, entendemos ser importante fazer duas ponderações, quais sejam: primeiramente, vale lembrar que, para estar em relação, em efetiva interação, é preciso conectar-se, ato que implica estar "ligado a, junto com", e não "acima de". Logo, é também papel da escola criar ambientes mais colaborativos, em vez de competitivos; em segundo lugar, a ideia de que um aluno pode, na aprendizagem, obter sucesso pela superação de outro contribui para um desvio importante na motivação do aprender: conhecer o mundo nos conduz à própria superação, haja vista que amplia a possibilidade de uso de novas lentes para compreendermos a nós próprios, ao outro, bem como a realidade. E o melhor modo de fazermos isso é na relação com o outro, mas como um parceiro, não como um adversário. Logo, não se trata de superar um colega que "sabe mais", e sim de superar a si mesmo, em parceria com um colega.

Abordar esses pontos é importante, uma vez que, ao longo da observação, pudemos constatar, no dia a dia da escola, como a comparação entre as crianças se faz presente; e comentários de alunos e de professores tendem a reforçar lugares estereotipados no grupo.

Do ponto de vista de Bianca, as concepções de aprender para agradar ao professor e de estar à frente na competição com os demais colegas podem até ser coerentes. Contudo, ao refletir sobre a práxis pedagógica, é necessário observar também quais atitudes docentes podem validar uma rivalidade entre as crianças ou podem estimulá-las a caminhar juntas, ainda mais quando esse tema diz respeito ao ato de aprender como motivação legítima em si. Sob essa perspectiva, é fundamental que o professor proponha situações em que os alunos possam atuar em parceria e com objetivos comuns, o que os auxiliaria a estabelecer trocas mais significativas na construção de conhecimentos. 


\section{c) Predomínio do trabalho individual}

Embora Bianca não tenha feito menção à modalidade de trabalho quando tratamos do tema na entrevista, durante a observação em classe, verificamos que, na realização de atividades de escrita, os alunos foram organizados de diferentes modos, como mostra o Quadro 16, a seguir:

Quadro 16 - Organização da turma $1^{\circ}$ ano

\begin{tabular}{|c|c|c|c|}
\hline Trabalho individual & Trabalho em duplas & $\begin{array}{c}\text { Trabalho em } \\
\text { pequenos grupos }\end{array}$ & Trabalho em grande grupo \\
\hline 9 & 3 & 0 & 6 \\
\hline \multicolumn{2}{|l}{ Total de atividades observadas } \\
\hline
\end{tabular}

Fonte: elaborado pela pesquisadora

Como se verifica, o trabalho dos alunos ocorreu predominantemente de modo individual. As aulas costumavam ser centralizadas no professor, com foco nas tarefas, sendo as crianças desestimuladas a conversar, mesmo quando se tratava de algo relativo à atividade que realizavam. $\mathrm{O}$ mesmo ocorreu quando um aluno tomava a iniciativa de ajudar o outro, o que era inibido sob a alegação de que "cada um tem que pensar por si mesmo". Esse cenário é justamente o oposto daquilo mais indicado pelos paradigmas interacionistas:

[...] a aprendizagem é definida situacionalmente por meio de padrões e práticas discursivas com os quais professores e alunos constroem a vida de cada sala de aula. [...]. Os processos de ensino e aprendizagem são vistos como processos sociais e interativos que ocorrem no interior de uma cultura específica produzida na escola, devendo, portanto, ser explorados dentro das situações reais em que ocorrem. (MACEDO, 2005, p. 15)

O trabalho em duplas foi proposto em três situações, mas sem que Bianca tivesse estipulado previamente algum critério para que houvesse a definição das parcerias. Embora estivessem sentados lado a lado, os alunos não trabalhavam, de fato, juntos, e tampouco tinham desafios cognitivos a enfrentar conjuntamente.

Verificamos que, por um lado, Bianca reconhece a importância das interações para a aprendizagem e crê atuar de modo a promovê-las; por outro lado, no entanto, privilegia o trabalho individual, pois entende que este seja o melhor modo de evitar que as crianças se distraiam e deixem de assimilar o que devem aprender. 
Essa contradição, tal como uma interação em que professor e alunos se ocupam mais da tarefa em si e menos da articulação intelectual que promove avanços conceituais, exige que se repense o papel das relações sociais nos processos de aprendizagem. Isso porque, como já discutido em capítulos anteriores, quando estão em situações interativas, mediadas pela linguagem e em condições colaborativas, professor e alunos podem se envolver em uma série de atividades para, progressivamente, desestabilizarem concepções prévias, e, assim, construírem significados em diferentes tarefas.

Em razão da diversidade existente entre os sujeitos, é possível, por meio da troca de ideias, desestabilizar concepções prévias, assim como ampliar capacidades. Em outras palavras, é possível assumir que as relações sociais são formativas quando a interação com o outro - seja este um adulto ou uma criança - fornece, além da dimensão afetiva, desafio e apoio para a atividade cognitiva. É dessa forma que as interações em sala de aula possibilitam o desenvolvimento de processos maturacionais, fazendo com que venham a se completar pela coordenação de diferentes pontos de vista e também pela elaboração e reelaboração de ideias.

Por isso, há que se considerar que todos os envolvidos no processo de ensino e aprendizagem devem estar em diálogo. Em uma relação na qual impera a equidade de papéis entre o discurso do professor e o dos alunos, é importante que não esteja definido, a priori, quem tem direito à voz (geralmente, o professor), ou quais enunciados serão ou não aceitos, sem que a criança tenha que se ocupar, previamente, de responder "o certo" ou "o que o professor deseja ouvir".

$E$, também, em virtude de os saberes dos alunos serem diferentes, as trocas de informações e de estratégias de pensamento entre eles deveriam ser bem-vindas e desejáveis.

\section{d) Diálogo nem sempre se constitui como processo interativo eficiente para a construção cognitiva}

Ao postularmos a interação como eixo relevante da relação entre os processos de aprendizagem e de ensino, justifica-se a necessidade de verificar não só as formas de organização e de agrupamento entre alunos (e, destes, com o professor), mas, também, como se dão os processos dialógicos entre os atores da sala de aula, pois, tal como asseveram García e Puig (2010), entendemos que 
Viver em comunidade é viver falando. A convivência é sempre transpassada pela palavra, uma vez que, por meio da linguagem, é possível elaborar uma compreensão conjunta de tudo o que afeta a coletividade e cada um de seus membros. Isso acontece porque a linguagem facilita a construção de soluções para os conflitos e de projetos comuns, e também porque, dialogando, cada um se sente comprometido com aqueles com quem fala. (GARCíA; PUIG, 2010, p. 68)

Logo, ainda que o papel da interação no processo de aprendizagem não tenha sido explicitamente tratado pela professora durante a entrevista, julgamos ser importante lançar luz sobre a natureza e a qualidade da interação predominante em sala de aula. O Quadro 17, a seguir, visa explicitar a dinâmica relacional observada.

Quadro 17 - Processos interativos presentes nas atividades de escrita - $1^{\circ}$ ano

\begin{tabular}{|c|c|c|}
\hline $\begin{array}{c}\text { Práticas dialogadas entre a } \\
\text { professora e os alunos }\end{array}$ & $\begin{array}{c}\text { Práticas dialogadas entre } \\
\text { alunos }\end{array}$ & Práticas não dialogadas \\
\hline 12 & 0 & 6 \\
\hline Total de atividades observadas & 18 \\
\hline
\end{tabular}

Fonte: elaborado pela pesquisadora

A partir do exposto, verifica-se que, ora a professora dava atenção especial aos alunos, ora circulava entre duplas de alunos e os orientava enquanto realizavam as tarefas e ora voltava-se ao grande grupo, dirigindo-se simultaneamente a todos os alunos, situação que prevaleceu sobre as demais e que parece compatível com o princípio (anteriormente discutido) de centralização do ensino na figura do professor, com foco nas tarefas.

Essa constatação pressupõe que, implicitamente, o tipo de interação predominantemente valorizado por Bianca diz respeito às situações em que o professor "dá aula", o que se justifica quando verificamos que é o professor quem fala na maior parte do tempo, instruindo os alunos ou explicando-lhes sobre assuntos diversos. De modo geral, estes estavam todos voltados para a frente da sala, mais especificamente, para a lousa, de onde a professora orientava a realização das propostas, tirava dúvidas, explicava conteúdos e mantinha o controle do grupo. Nessas ocasiões, foi comum vê-los acompanhando a professora que, por meio de perguntas, buscava conduzi-los em seu pensamento - intervenção declarada por ela como necessária e importante para que os alunos avancem em relação ao 
conhecimento; observa-se aqui, novamente, como é latente a crença de que a criança nada sabe, não tendo condições de ser protagonista do próprio pensar.

Observamos, também, momentos em que professora e alunos estavam em interação verbal de diferentes maneiras, as quais podem ser agrupadas ainda pela configuração da classe durante o trabalho, como se verifica no Quadro 18, a seguir:

Quadro 18 - Práticas dialogadas entre professora e alunos - $1^{\circ}$ ano

\begin{tabular}{|c|c|c|}
\hline $\begin{array}{c}\text { Diálogo entre a professora e o } \\
\text { grande grupo }\end{array}$ & $\begin{array}{c}\text { Diálogo entre a professora e } \\
\text { duplas de alunos }\end{array}$ & $\begin{array}{c}\text { Diálogo entre a professora e um } \\
\text { aluno }\end{array}$ \\
\hline 6 & 3 & 3 \\
\hline
\end{tabular}

Fonte: elaborado pela pesquisadora

Como se pode constatar por meio do quadro de observação, prevaleceram as situações em que Bianca se dirigia ao grupo classe como um todo. É preciso salientar, contudo, que a interação verbal nem sempre é capaz de garantir um diálogo em que prevaleça a troca de ideias e a busca conjunta de soluções para algum problema. Foi precisamente o que ocorreu, por exemplo, nas conversas entabuladas pela professora e que seguiam como padrão a realização de perguntas óbvias ou previsíveis aos alunos. A esse respeito, Pontecorvo, Ajello e Zuccermaglio apontam que

A estrutura usual das conversações em sala de aula - com a típica sequência pergunta do professor, resposta do aluno, comentário do professor - responde, sobretudo, ao objetivo de avaliar o aluno, verificando os conhecimentos que ele possui. Esse tipo de interação verbal não é "feito" para favorecer a construção de novos conhecimentos, muito menos a contraposição de pontos de vista. (PONTECORVO; AJELLO; ZUCCERMAGLIO, 2005, p. 67)

Diversas foram, também, as situações em que a professora e os alunos vivenciavam uma troca intensa por meio de perguntas de Bianca, que esperava a resposta "certa" das crianças e, por conseguinte, elogiava-as. Nessa dinâmica, por vezes, a professora também realizava uma pergunta e, imediatamente, já a respondia ela própria. Em outros momentos, questionava as crianças e, posteriormente, iniciava a resposta, como ocorreu nos exemplos explicitados a seguir: 
Situação 1:

- Professora: "Quem sabe como se escreve MACACO? Isso... começa com MA, M A!"

Situação 2:

- Professora: "Como é que vocês devem fazer a lição? Com CA..."

- Crianças: "PRICHO!"

Consciente ou inconscientemente, para Bianca parece relevante informar e induzir os alunos a respostas que já foram previamente concebidas por ela.

Diante da complexidade das situações que concorrem na vida pulsante de uma sala de aula, é possível compreender as contradições existentes na intenção de se instaurar o diálogo (entre e com os alunos) e, com efeito, dar conta de fazê-lo, uma vez que a oralidade pode ocorrer sem necessariamente permitir as trocas que a relação dialógica imprime.

Sob esse contexto, García e Puig (2010, p. 68) apontam o papel e a relevância de "reinventar a aula como espaço para o diálogo". Advertem, no entanto, que esse processo se dá somente pelo reconhecimento do protagonismo do grupo, e pela abordagem de temáticas significativas aos alunos, visando promover discussões e a procura conjunta de soluções.

Ressaltam, ainda, que é preciso buscar caminhos para se instaurar relações dialógicas em sala de aula, um caminho que não é simples, uma vez que

Colocar o diálogo no centro da vida coletiva requer, por parte dos professores, uma disposição coerente com o espírito democrático que está implícito nele e, por outro lado, implantar uma série de práticas que favoreçam o debate e o confronto de opiniões [...] (o que) obriga ao desenvolvimento de determinadas capacidades procedimentais, como: escutar, reconhecer os argumentos dos demais, confrontá-los com os próprios e elaborar mensagens claras. (GARCÍA; PUIG, 2010, p. 68)

Trazer a relevância do diálogo como prática pedagógica constitui uma oportunidade ímpar de repensar a atuação docente. Entendemos que, a fim de conseguir, efetivamente, alcançar uma relação dialógica com seus alunos, Bianca teria que se deslocar do centro do processo educativo e, assim, legitimar a voz dos alunos como seres pensantes, isto é, capazes de desenvolver recursos para poderem avançar na construção de conhecimentos. 


\section{e) Divisão da turma em dupla/grupos conforme a competência dos alunos}

Ao longo da investigação em sala de aula, observamos que, em alguns momentos, as crianças foram separadas em dois grupos distintos: as mais avançadas na aprendizagem dedicavam-se a uma tarefa de escrita, enquanto as menos avançadas, realizavam outra tarefa. Foi o que ocorreu nas atividades $1 \mathrm{a}$ e 1b, $5.1 \mathrm{a}$ e 5.1b, 7a e 7b e 11.2a e 11.2b; segundo Bianca, essa distinção visava ajudar os mais atrasados, para que estes avançassem na alfabetização, com ajuda da professora, ao mesmo tempo em que permitiria aos que sabiam mais, seguir caminhando na aprendizagem.

Notamos, no entanto, que a divisão dos grupos não garantia a troca entre os alunos; pelo contrário, eram situações em que, supostamente (uma concepção implícita da docente), só o foco na professora garantiria a realização acertada das tarefas.

Observamos aqui, também, mais uma concepção implícita na prática de Bianca, que, ao dividir os alunos por grupos de competência, subentende não ser produtivo aproximar alunos com diferentes níveis de conhecimento, isto é, pressupõe que a heterogeneidade dificulta as possibilidades de aprender.

Corrobora-se aí um princípio já discutido por Colello (2017), de que a aproximação de alunos mais competentes e daqueles "com dificuldade" poderia prejudicar os primeiros (que teriam que esperar e auxiliar os demais, deixando, assim, de aprender), ao passo que desperdiçaria o tempo dos menos competentes, que provavelmente não conseguiriam acompanhar os mais avançados.

Por ser a heterogeneidade de saberes um complicador, o objetivo do trabalho passa a ser, então, homogeneizar o conhecimento do grupo, de modo que todos atinjam as mesmas metas, ao mesmo tempo (o que, neste caso, significaria o domínio da base alfabética até o final do primeiro ano).

Observamos também que, ao supervisionar direta e proximamente os alunos, pressupõe que os conhecimentos prévios das crianças, bem como seus recursos reflexivos, não são necessariamente suficientes para que avancem sozinhos em suas hipóteses sobre a escrita, o que parece compatível com o princípio anteriormente discutido de controlar a aprendizagem: o acompanhamento, passo a passo, da professora parece, de fato, nortear sua conduta pedagógica. Por conta disso, entende ser mais adequado que trabalhem individualmente, e não com os pares. 
Tais acepções, embora implícitas, revelam as perspectivas conflitantes de Bianca: por um lado, é ineficaz juntar alunos com níveis desiguais de conhecimento, pois a diferença de saberes pode prejudicar os que sabem mais; por outro, também parece contraindicado juntar alunos com níveis semelhantes, uma vez que não há o que acrescentar entre um e outro.

Parece-nos que, do ponto de vista de Bianca, a possibilidade de aproximar alunos com níveis semelhantes de conhecimento se apresenta como melhor estratégia justamente porque vem acompanhada de menor interação entre as crianças.

Isso porque, nas situações de ensino, o professor coloca-se como principal informante, buscando transmitir conhecimento aos alunos em um grupo menor, sobre o qual exerce mais controle, ao mesmo tempo em que pode mais facilmente avaliar a todos e a cada um. Não se trata, pois, de pensar nos agrupamentos mais produtivos tendo em vista a qualidade das trocas possíveis entre os discentes, e sim dos agrupamentos em que o ensino centralizado na figura do professor fica mais garantido.

A título de conclusão parcial, salientamos alguns aspectos relevantes no contexto da presente pesquisa.

Se, por um lado, os vínculos socio afetivos são fundamentais para a aprendizagem, há que se abordar igualmente o papel do professor como aquele que favorece o vínculo do aluno com o conhecimento, despertando nele o desejo de aprender sempre mais e instrumentalizando-o para que desenvolva autonomia intelectual.

Do mesmo modo, é essencial valorizar e promover interações em que as diferenças entre os aprendizes possam, com efeito, contribuir para novas aprendizagens, as quais devem pautar-se na cooperação e no diálogo produtivo entre os alunos e, destes, com o professor.

Com a expectativa de avaliar as perspectivas de progressão dos anos escolares no que concerne à língua, ao ensino e aprendizagem e às interações em sala de aula, no próximo capítulo, pretendemos analisar os dados da turma de segundo ano. 


\section{CONCEPÇÕES E PRÁTICAS DE ESCRITA NO SEGUNDO ANO}

Neste capítulo pretendemos analisar os dados do segundo ano com base na entrevista realizada com a professora e nos registros de observação em classe, a fim de buscar as relações entre as concepções e a prática docente.

\subsection{Concepções Docentes e Práticas Pedagógicas}

No que diz respeito às concepções depreendidas da entrevista com Raquel, professora do $2^{\circ}$ ano, o Quadro 19, a seguir, sintetiza seus posicionamentos relativos à língua, ensino e aprendizagem e interação: 
Quadro 19 - Concepções assumidas pela professora Raquel - $2^{\circ}$ ano (Entrevista) ${ }^{35}$

\begin{tabular}{|c|c|c|}
\hline \multicolumn{3}{|c|}{ 20 Ano } \\
\hline Língua & Ensino e Aprendizagem & Interação \\
\hline $\begin{array}{l}\text { A escrita permite o } \\
\text { registro, o qual leva à } \\
\text { preservação da } \\
\text { memória. } \\
\text { A escrita é um meio de } \\
\text { comunicação que } \\
\text { atende à necessidade } \\
\text { de se relacionar com os } \\
\text { demais. } \\
\text { Por meio da escrita é } \\
\text { possível atender às } \\
\text { demandas da vida } \\
\text { cotidiana e participar } \\
\text { da vida em sociedade, } \\
\text { fazendo valer direitos. }\end{array}$ & 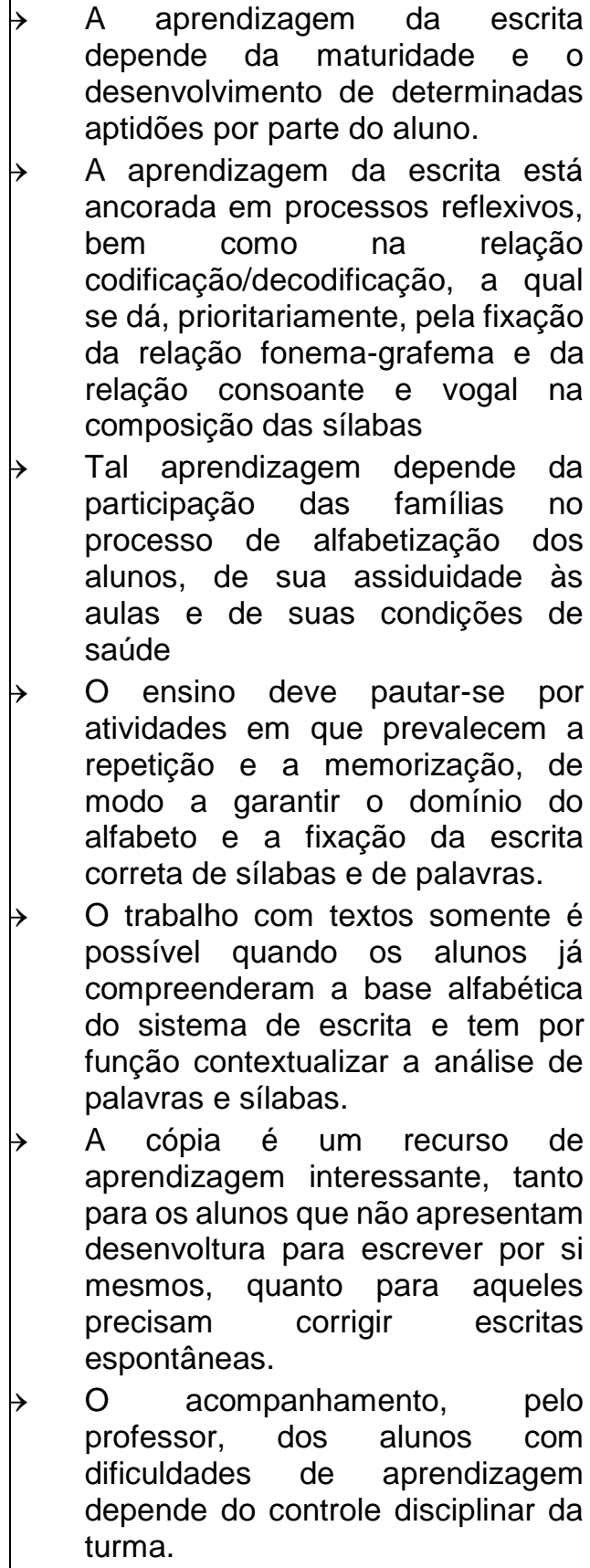 & 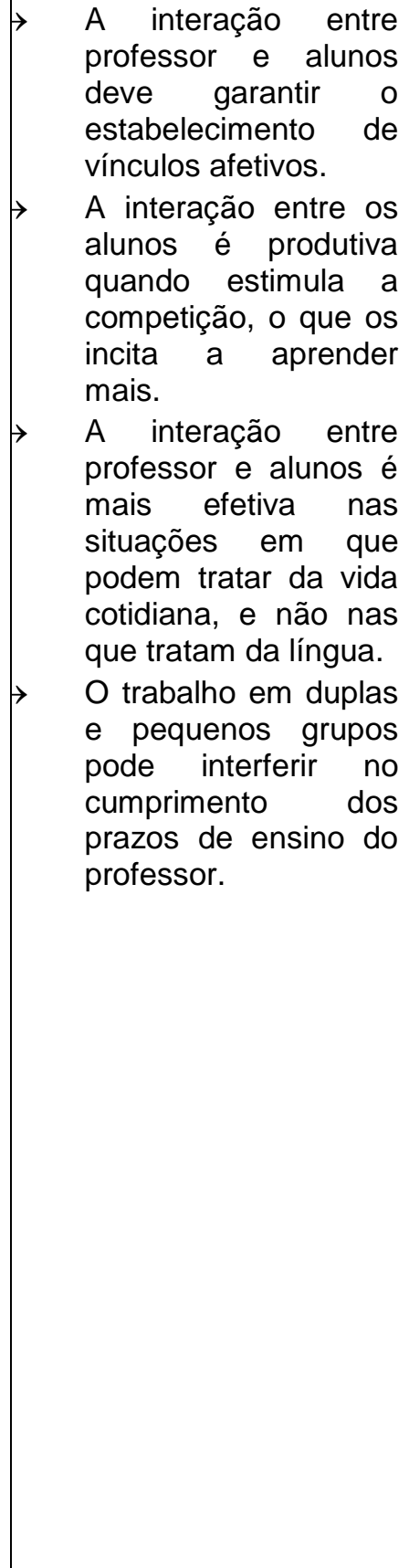 \\
\hline
\end{tabular}

Fonte: elaborado pela pesquisadora

No que diz respeito à prática em sala de aula, a professora propôs 28 atividades destinadas ao ensino da língua, organizadas conforme os critérios de análise, no Quadro 20, que segue:

35 Questões da entrevista (apresentadas no capítulo 5): Para você, o que é a língua escrita? De que modo a criança aprende a língua escrita? Como a escrita deve ser ensinada na escola? Como você vê as interações (entre alunos e entre alunos e o professor) e a aprendizagem da língua? 
Quadro 20 - Propostas de escrita junto aos alunos do $2^{\circ}$ ano

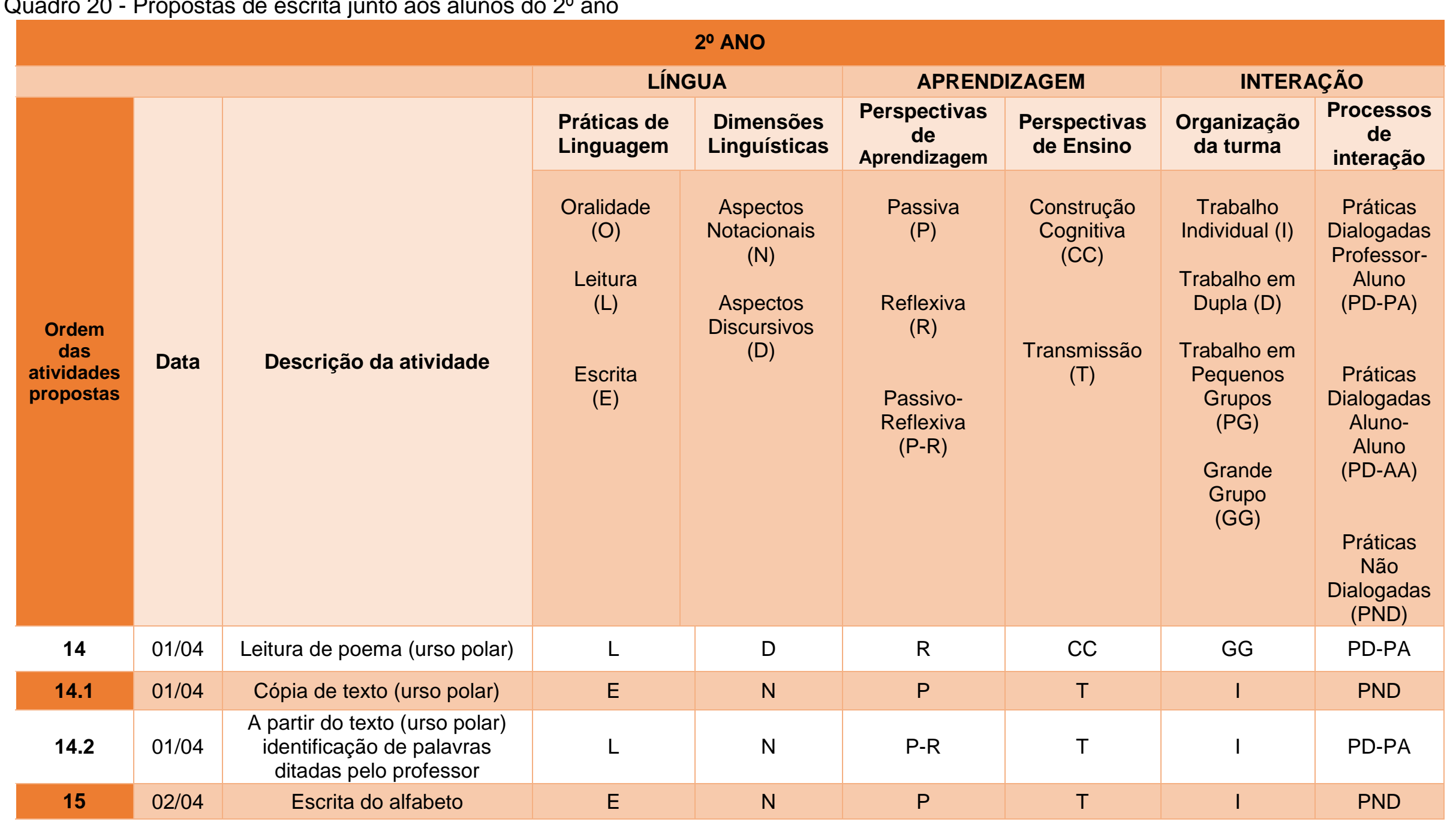




\begin{tabular}{|c|c|c|c|c|c|c|c|c|}
\hline 16 & $03 / 04$ & $\begin{array}{c}\text { Escrita de uma lista de } \\
\text { palavras (Coisas que precisam } \\
\text { quando vão à praia) }\end{array}$ & $\mathrm{E}$ & $\mathrm{N}$ & $\mathrm{P}-\mathrm{R}$ & $\mathrm{T}$ & 1 & PD-PA \\
\hline 17 & 05/04 & $\begin{array}{l}\text { Escrita de texto memorizado } \\
\text { (cantiga Corre Cotia) }\end{array}$ & $\mathrm{E}$ & $\mathrm{N}$ & P-R & $\mathrm{T}$ & D & PD-PA \\
\hline 18 & $08 / 04$ & $\begin{array}{l}\text { Escrita de bilhete (alertar João } \\
\text { e Maria sobre a casa de doces } \\
\text { da bruxa) }\end{array}$ & $\mathrm{E}$ & $\mathrm{D}$ & $\mathrm{R}$ & CC & I & PND \\
\hline 19 & $09 / 04$ & Leitura de poema (vaga-lume) & $\mathrm{L}$ & $\mathrm{D}$ & $\mathrm{R}$ & $\mathrm{CC}$ & 1 & PND \\
\hline 19.1 & $09 / 04$ & Cópia de texto (vaga-lume) & $\mathrm{E}$ & $\mathrm{N}$ & $\mathrm{P}$ & $\mathrm{T}$ & 1 & PND \\
\hline 19.2 & 09/04 & $\begin{array}{l}\text { A partir do texto (vaga-lume) } \\
\text { identificação de palavras } \\
\text { ditadas pelo professor }\end{array}$ & $\mathrm{L}$ & $\mathrm{N}$ & P-R & $\mathrm{T}$ & I & PD-PA \\
\hline 20 & $10 / 04$ & $\begin{array}{l}\text { Leitura de parlenda (Dom } \\
\text { Frederico) }\end{array}$ & $\mathrm{L}$ & $\mathrm{D}$ & $\mathrm{R}$ & CC & GG & PD-PA \\
\hline 20.1 & $10 / 04$ & $\begin{array}{l}\text { Cópia dos versos de uma } \\
\text { parlenda (Dom Frederico) }\end{array}$ & $E$ & $\mathrm{~N}$ & $P$ & $\mathrm{~T}$ & I & PND \\
\hline 20.2 & $10 / 04$ & $\begin{array}{c}\text { Identificação de palavras que } \\
\text { rimam (Parlenda Dom } \\
\text { Frederico) }\end{array}$ & $\mathrm{O}$ & $\mathrm{N}$ & $\mathrm{P}-\mathrm{R}$ & $\mathrm{T}$ & I & PD-PA \\
\hline 21 & $11 / 04$ & $\begin{array}{l}\text { Completar com vogais uma } \\
\text { lista de palavras (nomes de } \\
\text { brinquedos) escritas só com } \\
\text { consoantes }\end{array}$ & $E$ & $\mathrm{~N}$ & P-R & $\mathrm{T}$ & I & PD-PA \\
\hline 22 & $12 / 04$ & $\begin{array}{l}\text { Cópia do alfabeto, separando } \\
\text { vogais e consoantes }\end{array}$ & $\mathrm{E}$ & $\mathrm{N}$ & $P$ & $\mathrm{~T}$ & 1 & PND \\
\hline 22.1 & $12 / 04$ & Leitura de nomes próprios & $\mathrm{L}$ & $\mathrm{N}$ & $\mathrm{R}$ & $\mathrm{CC}$ & I & PND \\
\hline 22.2 & $12 / 04$ & $\begin{array}{l}\text { Cópia de nomes próprios, } \\
\text { separando os que iniciam com } \\
\text { vogal e consoante }\end{array}$ & $E$ & $\mathrm{~N}$ & $\mathrm{P}$ & $\mathrm{T}$ & I & PND \\
\hline 23 & $15 / 04$ & $\begin{array}{c}\text { Leitura de conto (Dudu e a } \\
\text { tagarela Bac) }\end{array}$ & $\mathrm{L}$ & $\mathrm{D}$ & $\mathrm{R}$ & CC & GG & PD-PA \\
\hline 24 & $16 / 04$ & $\begin{array}{l}\text { Leitura de conto (O abraço do } \\
\text { gigante) }\end{array}$ & $\mathrm{L}$ & D & $\mathrm{R}$ & CC & GG & PD-PA \\
\hline
\end{tabular}




\begin{tabular}{|c|c|c|c|c|c|c|c|c|}
\hline 24.1 & $16 / 04$ & $\begin{array}{l}\text { Cópia de palavras que } \\
\text { começam com G, de } \\
\text { GIGANTE }\end{array}$ & $E$ & $\mathrm{~N}$ & $\mathrm{P}$ & $\mathrm{T}$ & I & PND \\
\hline 25 & $17 / 04$ & $\begin{array}{l}\text { Escrita de palavras a partir de } \\
\text { figuras (formas de lazer } \\
\text { vividas pelos alunos: } \\
\text { PARQUE, PISCINA, } \\
\text { CINEMA...) }\end{array}$ & $E$ & $\mathrm{~N}$ & $\mathrm{R}$ & $\mathrm{CC}$ & $\mathrm{D}$ & PD-PA \\
\hline $26 a$ & $23 / 04$ & $\begin{array}{l}\text { Leitura de palavras (nomes de } \\
\text { frutas) escritas sem } \\
\text { segmentação entre elas }\end{array}$ & $\mathrm{L}$ & $\mathrm{N}$ & P-R & $\mathrm{T}$ & $P G$ & PD-PA \\
\hline $26.1 \mathrm{a}$ & $23 / 04$ & $\begin{array}{l}\text { Cópia de palavras (nomes de } \\
\text { frutas) separando-as entre si }\end{array}$ & $E$ & $\mathrm{~N}$ & P-R & $\mathrm{T}$ & $P G$ & PND \\
\hline $26 \mathrm{~b}$ & $23 / 04$ & $\begin{array}{l}\text { Leitura de frases (sobre } \\
\text { brinquedos) }\end{array}$ & $\mathrm{L}$ & $\mathrm{N}$ & $\mathrm{R}$ & $\mathrm{CC}$ & I & PD-PA \\
\hline $26.1 \mathrm{~b}$ & $23 / 04$ & $\begin{array}{c}\text { Cópia de frases segmentando } \\
\text { palavras entre si (sobre } \\
\text { brinquedos) }\end{array}$ & $E$ & $\mathrm{~N}$ & P-R & $\mathrm{T}$ & I & PND \\
\hline 27 & $25 / 04$ & $\begin{array}{l}\text { Leitura de conto (Quando o } \\
\text { lobo tem fome) }\end{array}$ & $\mathrm{L}$ & $\mathrm{D}$ & $\mathrm{R}$ & $\mathrm{CC}$ & GG & PD-PA \\
\hline 27.1 & $25 / 04$ & $\begin{array}{l}\text { Conversa coletiva- Descrição } \\
\text { e comparação de personagem } \\
\text { a partir de duas histórias (o } \\
\text { lobo do conto anterior e o de } \\
\text { Chapeuzinho Vermelho) }\end{array}$ & $\mathrm{O}$ & $D$ & P-R & $\mathrm{T}$ & $\mathrm{GG}$ & PD-PA \\
\hline 27.2 & $25 / 04$ & $\begin{array}{c}\text { Cópia da descrição e } \\
\text { comparação de personagem a } \\
\text { partir de duas histórias (o lobo } \\
\text { do conto anterior e o de } \\
\text { Chapeuzinho Vermelho) }\end{array}$ & $E$ & $\mathrm{D}$ & $\mathrm{P}$ & $\mathrm{T}$ & I & PND \\
\hline & \multicolumn{2}{|c|}{ Total de atividades observadas } & \multicolumn{6}{|c|}{28} \\
\hline
\end{tabular}




\subsection{Língua no $2^{\circ}$ ano}

Logo no início da entrevista, Raquel, professora do $2^{0}$ ano, destaca a importância da escrita em sociedades letradas, apontando para seus usos sociais. Entretanto, se por um lado, suas considerações dizem respeito ao reconhecimento da escrita como prática social, por outro, em alguns momentos, suas práticas parecem desviar-se desse princípio, enveredando para abordagens mais técnicas relacionadas ao sistema da escrita.

Assim, a análise dos dados obtidos durante a pesquisa permite-nos destacar aspectos contraditórios entre o discurso e a prática pedagógica, dentre os quais salientamos:

\section{a) A valorização da escrita como meio de comunicação e de socialização}

Ao tratar a escrita como um meio de comunicação, Raquel, assim como Bianca, expõe seu caráter de amplificação de informações e ideias, o que se dá por distintos meios, como também aponta Colello (2007, p. 11):

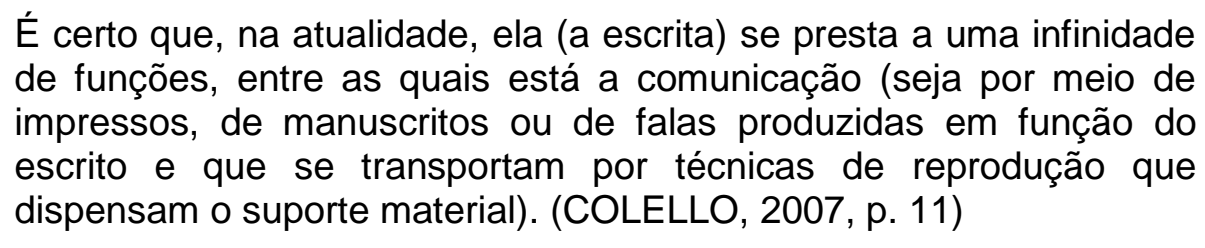

Segundo o dicionário Houaiss da Língua Portuguesa, a palavra "comunicação" tem origem no latim communicatio.onis e significa "ação de participar" (HOUAISS, 2020). Em outras palavras, ao comunicarem, os indivíduos compartilham ideias, emoções e saberes, de modo que estes passam a fazer parte de um universo comum, podendo decorrer daí sentimentos de união e pertença o que estreita os vínculos sociais.

Distintos são os meios pelos quais a comunicação escrita se manifesta em função de diferentes propósitos, havendo instrumentos diversos capazes de propagar informações, como o jornal e os livros, além daqueles que permitem a aproximação mais pessoal, como as cartas, os bilhetes e telegramas.

No contexto da modernidade, novas demandas sociais, atreladas ao avanço tecnológico, têm dado lugar a formas inéditas de comunicação, as quais originam novas mídias digitais, como as redes sociais, dentre as quais destacam-se, 
atualmente, blogs, sites e aplicativos que visam contatar pessoas. Tais mídias garantem, ainda que virtualmente, a proximidade entre os indivíduos, que estando cada vez mais conectados, têm a sensação de proximidade.

\section{b) A escrita como perpetuação da memória}

Ao situar a escrita como recurso de comunicação, Raquel aprofunda a sua concepção sobre língua apontando ainda o caráter de permanência da escrita, a qual ultrapassa os limites do tempo e do espaço, viabilizando a construção de legados que ficam para a posteridade.

Sua consideração se faz relevante por chamar à atenção para uma das funções da escrita: garantir a memória, tanto individual, quanto coletiva. Por meio da escrita, bem como da fotografia e de filmagens, por exemplo, ideias, acontecimentos e experiências se eternizam, imortalizando as lembranças por meio de registros.

Quando os homens sentiram pela primeira vez a necessidade de registrar, contar, perpetuar um fato, acontecimento ou simplesmente controlar a quantidade de grãos existentes em um estoque ou contabilizar uma dívida, inventaram signos e símbolos capazes de auxiliar na memorização. Assim, a escrita foi se construindo como elemento indispensável na história da civilização, primeiro como traços, desenhos, pequenas marcações nas rochas e no barro, depois, já como alfabeto, sobre o papiro ou o pergaminho. A partir desse momento, o homem não cessa de reinventar senão a escrita, os suportes para armazená-la. Nossas últimas invenções dão um salto imenso para a conservação da história da humanidade: a web e o ebook. [...] A utilização da linguagem escrita é, sem dúvida, uma ampliação considerável da capacidade de armazenamento de nossa memória, o que permite ultrapassar os limites do corpo para outras formas de preservação (VARANDA; MAGRI, 2011, s/p)

Colello (2007) salienta como, além de perpetuar lembranças, a escrita, quando ancorada nas funções de registro e resgate da memória, potencializa o pensamento descontextualizado das situações imediatas, sustentando ainda mais possibilidades humanas de reflexão.

Um [...] aspecto a considerar diz respeito às formas de organização do pensamento e da própria fala. Os sistemas de escrita, bem como os meios modernos de tecnologia que os incorporam, são um poderoso instrumento de expansão e registro de memória. Essa expansão da memória permite aos indivíduos e grupos maior atuação intelectual e maior intervenção no espaço, uma vez que, não sendo preciso guardar na mente todas as informações, mensagens, ideias, raciocínios, armazena-se a "informação" fora do corpo, embora ao alcance do 
sujeito, desde que ele domine a tecnologia. O desenvolvimento dessa tecnologia extremamente poderosa, que permite a fixação dos modos de pensar e de organizar o pensamento pela representação das palavras, implicou profundas transformações na forma de ser e viver dos homens, incluindo o pensamento descontextualizado, abstrato, dissociado da situação imediata. (COLELLO, 2007, p. 11-12)

Vale apontar ainda como a escrita, pela possibilidade do registro que garante a memória "fora do corpo, mas ao alcance do sujeito" (COLELLO, 2007, p. 11), permite alcançar uma visão processual das situações, concretizando a historicidade, justamente porque oportuniza não começar percursos do zero.

\section{c) A valorização da escrita como prática social}

Tal como como a professora do primeiro ano, Raquel aponta a importância da escrita por sua funcionalidade em situações corriqueiras da vida. Por meio de exemplos, como a possibilidade de fazer uso do transporte público e de preencher documentos e formulários, justifica a relevância do domínio dessa modalidade linguística justamente por sua falta, alegando como a vida daqueles que não dominam a leitura e a escrita é difícil, especialmente àqueles que vivem em grandes centros urbanos.

As considerações da professora merecem ponderação, pois trazem à luz o domínio da escrita em seu caráter instrumental, na realização de tarefas cotidianas. Situando a escrita como prática social, ela toca em um ponto que exige maior reflexão e compromisso da instituição escolar: a questão do analfabetismo funcional, que assola muitas pessoas que frequentaram a escola. Dados do INEP e de outros órgãos, governamentais e civis, constatam como o analfabetismo funcional tem diminuído ao longo do tempo, mas revelam que a situação ainda é preocupante e corroboram as demandas por maior eficiência do trabalho escolar.

A cada 10 brasileiros, três não conseguem resolver operações básicas que envolvam, por exemplo, o total de uma compra, o cálculo do troco ou valor de prestações sem juros quando vão ao supermercado. Para essas pessoas, muitas tarefas do cotidiano são grandes desafios, dificultando a cidadania crítica e uma vida com autonomia. (CAMPOS JÚNIOR, 2018, s/p)

A esse respeito, Colello (2007) reconhece o caráter instrumental da alfabetização, mas amplia a reflexão, alegando que é preciso atribuir à aprendizagem 
da língua a condição de legítimo conhecimento com conotação educativa, fundamental ao ser humano.

É no conjunto das práticas sociais que a escrita revela-se na plenitude de seu potencial, infelizmente nem sempre acessível a todos os que aprendem a ler e escrever, razão pela qual as práticas de alfabetização, superando a esfera pedagógica, revestem-se de significado político. No contexto de nossa sociedade, alfabetizar é também dar voz ao sujeito, assim como favorecer meios críticos de participação social. (COLELLO, 2007, p. 29)

É importante registrar aqui que, embora Raquel assuma e valorize a língua como prática social, ao tratar do ensino da escrita, durante o período observado pela pesquisadora, distanciou-se desse pressuposto, promovendo, prioritariamente, como se verá adiante, atividades artificiais e mecânicas junto aos alunos. De fato, as atividades concentraram-se mais na ênfase notacional da escrita do que no uso da escrita como prática social.

\section{d) A escrita como possibilidade de exercício da cidadania}

Ao longo da entrevista, Raquel também declara a importância da escrita para o efetivo exercício de direitos. Alegando que estar alfabetizado permite resolver problemas que se apresentam na vida cotidiana, bem como promove o sentimento de pertença à vida em comunidade letrada, pois "quem sabe ler pode ler placas, entender contratos e não ser passado para trás", especialmente em vivências comerciais.

Parece-nos bastante oportuna sua observação, evidenciando a dimensão política da aprendizagem da língua, já que dominá-la, ou não, em seus usos e práticas sociais, permite a participação no mundo em maior ou menor grau. Daí a importância de compreender o alfabetismo como um direito a ser garantido a todos os sujeitos, de modo que possam exercer a cidadania nos mais diversos contextos sociais. Trata-se de reconhecer o domínio da palavra como instrumento de poder, no sentido de "empoderamento para pertencer". A esse respeito, Fiorin (2009, p. 164) lembra que

Os usos linguísticos podem ser o espaço da pertença, mas também da exclusão, da separação e até da eliminação do outro. Por isso, a língua não é um instrumento neutro de comunicação, mas é atravessada pela política, pelo poder, pelos poderes. (FIORIN, 2009, p. 164) 
Com base nos tópicos elencados sobre a concepção de escrita de Raquel (itens a, b, c, d), é possível destacar uma diferença entre ambas as professoras estudadas. Embora Bianca, do $1^{\circ}$ ano, faça referência explícita e genérica ao papel social da escrita e à comunicação, seu discurso parece mais vago do que o de Raquel, que faz questão de mencionar a escrita, de forma mais detalhada, chamando atenção para diferentes dimensões: a escrita como prática social e constituição da cidadania, como processo comunicativo com potencial para garantir a socialização, o vínculo de proximidade na relação entre as pessoas e a garantia da memória. Tal postura não garante, como veremos a seguir, que as práticas de ensino possam contemplar todas essas condições e significados.

\subsection{Ensino e aprendizagem no $2 \stackrel{0}{2}$ ano}

Ainda que Raquel aponte aspectos importantes ao se referir à língua, na prática, foi possível observar concepções implícitas e princípios pedagógicos que parecem nortear as propostas de escrita em um sentido diferente. Assim, considerando as concepções assumidas no âmbito do discurso e aquelas que aparecem implicitamente no trabalho junto aos alunos, destacamos os seguintes aspectos:

\section{a) Ênfase na aprendizagem pela maturação e desenvolvimento de aptidões}

Ao definir as condições fundamentais de aprendizagem da escrita, Raquel aponta que os alunos devem estar aptos para se alfabetizarem, o que, em sua perspectiva, implica "pegar corretamente o lápis, saber usar corretamente o caderno e ter habilidade de copiar da lousa".

Como a aprendizagem, nessa ótica, está atrelada à percepção, coordenação motora e discriminação sensorial, subentende-se que, enquanto as crianças ainda não amadureceram tais capacidades, poderiam ter dificuldades para se alfabetizar. Raquel afirma também que, como se aprende a partir de estímulos orais e visuais, cabe ao professor oferecê-los, o que implica explicitar aos alunos a relação entre os sons dos fonemas e seu "desenho", visualmente reconhecível por meio das letras. 
De fato, ao longo da observação em classe, foi possível presenciar a preocupação da professora em promover atividades que envolviam o conhecimento sobre letras, como se vê nas propostas 15, 21, 22, 22.2, 24.1.

A esse respeito, retomamos os estudos da Psicogênese da aquisição da escrita, os quais demonstram que a complexidade dos processos de construção cognitiva pela criança que aprende a escrita são incompatíveis com os princípios de "prontidão para a alfabetização", uma vez que a apropriação da escrita está ancorada em hipóteses formuladas e reformuladas pelo aprendiz, a partir de seus conhecimentos prévios e das assimilações e generalizações de seu pensamento. Weisz e Sanchez (1999, p. VIII), lembrando as concepções já ultrapassadas do século $X X$, foca especificamente nessa ideia, criticando-a:

Outra ideia corrente na época era a de que havia pré-requisitos para que alguém pudesse aprender a ler (e escrever). Um conjunto de habilidades perceptuais conhecidas como "prontidão para a alfabetização". O que Emília Ferreiro e Ana Teberosky demonstraram é que a questão crucial da alfabetização inicial é de natureza conceitual. Isto é, a mão que escreve e o olho que lê estão sob o comando de um cérebro que pensa sobre a escrita que existe em seu meio social e com a qual toma contato através de sua própria participação em atos que envolvem o ler e o escrever, em práticas sociais mediadas pela escrita.

Ferreiro (2002, p. 27) vai mais longe nessa mesma crítica, ponderando os resultados disso a longo prazo e em larga escala:

Há crianças que ingressam na língua por meio da magia (uma magia cognitivamente desafiante) e crianças que entram na língua escrita pelo treino de "habilidades básicas". Em geral, as primeiras se tornam leitoras; as outras têm um destino incerto.

\section{b) Professor como centro do processo pedagógico}

Como a professora do primeiro ano, Raquel parecia compreender a importância de seu papel como responsável pelo encaminhamento do trabalho pedagógico junto aos alunos. Suas considerações no âmbito discursivo sugeriam concepções relevantes no trabalho com a língua.

No entanto, sua prática apontava, implicitamente, para uma concepção de aprendizagem sustentada pela diretividade do professor, que definia os conteúdos independentemente dos saberes e dos processos cognitivos dos alunos. Ignorando o 
que as crianças sabiam, bem como suas demandas de aprendizagem, por conceber que os alunos aprendem pela estimulação e o desenvolvimento de habilidades, Raquel se colocava na posição daquela que fomenta a aprendizagem por meio de "estímulos", centralizando o desenvolvimento das tarefas. Mais uma vez, trata-se de uma postura que faz sentido na ótica docente, mas não necessariamente, adequadas do ponto de vista de quem aprende.

Para Weisz e Sanchez (2002, p. 19) essa postura faz parte de um momento histórico em que

Não havia um conhecimento científico acumulado que [...] permitisse superar um ponto de vista adultocêntrico: a forma pela qual se costuma conceber a aprendizagem das crianças a partir da própria perspectiva do adulto que já domina o conteúdo que quer ensinar. Dessa forma, não é possível compreender o ponto de vista do aprendiz, pois não se pode "enxergar" o objeto de seu conhecimento com os olhos de quem ainda não sabe.

\section{c) Pouca clareza sobre as necessidades de aprendizagem dos alunos}

Estreitamente vinculado ao tópico anterior é possível situar a fragilidade do ponto de vista da professora na compreensão de seus alunos. Embora mostrasse preocupação em promover um "bom ensino", Raquel, assim como sua colega Bianca, nem sempre parecia ter claro quais eram as necessidades de aprendizagem dos alunos, que se encontravam em diferentes níveis de conceitualização da escrita. Ao planejar o trabalho, igualmente, desconsiderava seus conhecimentos prévios, o que a levava, diversas vezes, a propor atividades em que faltava articulação entre o que entendia ser importante ensinar e os saberes e demandas de aprendizagem das crianças.

Ora, sabemos que

Compreender a perspectiva pela qual a criança enxerga o conteúdo é algo que, em muitos casos só é possível se o professor se colocar numa posição de observador cuidadoso daquilo que o aluno diz ou faz em relação ao que está sendo ensinado (WEISZ, SANCHEZ, 2002, p. 43)

Quando isso não acontece temos um verdadeiro distanciamento entre o ensinar e o aprender. A constatação desse descompasso torna-se evidente em diversas situações, como naquelas em que todos os alunos realizaram as mesmas propostas, 
independentemente de quais conjecturas sustentavam seus processos reflexivos; e poucas foram as situações observadas em que as crianças puderam colocar em jogo o que sabiam para poder resolver problemas reais vinculados à aprendizagem da língua.

De fato, apenas nas propostas $26.1 \mathrm{a}$ e $26.1 \mathrm{~b}$ os alunos forma divididos segundo suas competências de aprendizagem, realizando atividades diferentes. No entanto, ambas situações se referiam à cópia, a qual focava palavras (para os alunos que se encontravam nos níveis pré-silábico e silábico) e frases (para os alunos que se encontravam nos níveis silábico-alfabético e alfabético). Observamos também que, apenas nas propostas 16, 18 e 25 , as crianças puderam, a partir de seus conhecimentos prévios, elaborar e reelaborar hipóteses ao refletirem sobre a língua.

\section{d) Distanciamento de uma perspectiva de aprendizagem reflexiva}

Apoiadas no referencial piagetiano, Weisz e Sanchez (2002, p. 45) explicam que a construção do conhecimento é "um casamento entre a disponibilidade da informação externa e a possibilidade da construção interna", o que pressupõe um constante processo reflexivo de elaboração pessoal. Esse "casamento" nem sempre é bem entendido pelos professores que supervalorizam a informação como eixo prioritário da aprendizagem

Durante a entrevista, Raquel assume que os alunos aprendem por construção cognitiva; entretanto, afirma em seguida, que a aprendizagem da escrita está ancorada na relação codificação/decodificação, e justifica, alegando que "a criança pensa e constrói hipóteses sobre a escrita quando o professor lhe mostra que cada letra tem um som, e que uma letra sozinha não dá para escrever direito; somente aí percebe que precisa juntar uma vogal com uma consoante."

A perspectiva de que a capacidade reflexiva do aluno depende, diretamente, do grau de informatividade oferecido pelo professor fica evidente também na seguinte afirmação da professora: "Como muitos alunos não têm desenvoltura para escrever sozinhos, o professor pode escrever na lousa para eles pensarem junto com ela, e copiarem no próprio livro depois."

Nesse momento, a professora revela a crença de que algumas crianças, pelo seu estágio de desenvolvimento cognitivo, são incapazes de refletir sozinhas, o que confirma o princípio de que não têm condições de aprender se não forem informadas 
por um outro. Desse modo, muitas vezes, seu esforço para transmitir conhecimentos desconsidera tanto a compreensão do aluno quanto suas possibilidades de reflexão.

Durante a observação das práticas, observamos a desarticulação entre as perspectivas de aprendizagem e de ensino, já que mesmo diante de atividades de escrita, orientadas pelo princípio da reflexão, o professor assume o papel de transmissor de conhecimentos, remetendo os alunos a uma condição mais passiva.

O Quadro 21, a seguir, procura fazer o cruzamento entre as perspectivas de aprendizagem contempladas pelas tarefas e os processos de ensino que efetivamente ocorreram.

Quadro 21 - Perspectivas de Ensino e de Aprendizagem - $2^{\circ}$ ano

\begin{tabular}{|c|c|c|c|}
\hline $\begin{array}{c}\text { Perspectivas de } \\
\text { Aprendizagem }\end{array}$ & $\begin{array}{c}\text { Ensino pautado pela } \\
\text { Construção Cognitiva }\end{array}$ & $\begin{array}{c}\text { Ensino pautado pela } \\
\text { Transmissão de saberes }\end{array}$ & \\
\hline $\begin{array}{c}\text { Aprendizagem } \\
\text { Reflexiva }\end{array}$ & 2 & 0 & $\begin{array}{c}\text { Total de } \\
\text { atividades } \\
\text { de escrita } \\
\text { observadas }\end{array}$ \\
\cline { 1 - 2 } Aprendizagem Passiva & 0 & 8 & \\
\hline $\begin{array}{c}\text { Aprendizagem Passivo- } \\
\text { Reflexiva }\end{array}$ & 0 & 5 & 15 \\
\hline
\end{tabular}

Fonte: elaborado pela pesquisadora

Como se pode ver, as expectativas de aprendizagem de duas propostas (18 e 25) previam um aluno reflexivo, havendo coerência com a perspectiva de ensino, a qual se pautava na construção cognitiva.

Em oito propostas $(14.1,15,19.1,20.1,22,22.2,24.1,27.2)$, ainda que o professor não tenha declarado como perspectiva de aprendizagem a passividade do aluno, esta aparece implícita em sua prática, fundamentada em um ensino transmissivo.

Em cinco propostas $(16,17,21,26.1 \mathrm{a}, 26.1 \mathrm{~b})$ a perspectiva de aprendizagem previa um aluno reflexivo, capaz de elaborar e reelaborar hipóteses; no entanto, o modo e o encaminhamento das atividades, mais uma vez estiveram ancorados na transmissão e/ou repetição e memorização, constituindo uma postura transmissiva e diretiva de ensino. 


\section{e) Controle do ensino em função da aprendizagem dos alunos}

No âmbito discursivo, segundo Raquel, é preciso que o professor conduza o pensar do aluno, o qual nem sempre tem condições de avançar cognitivamente por si mesmo, principalmente se não estiver amadurecido ou não possuir habilidades específicas.

A preocupação de informar o aluno, desconsiderando seu potencial reflexivo, fica evidente também quando explica como planeja o trabalho didático, quando parte do plano mensal, elaborado por ela junto às demais professoras do ano, e segue, dividindo os conteúdos a serem tratados a cada mês em semanas, seguindo depois para o plano diário. Desse modo, o conteúdo a ser ensinado, estabelecido à priori e independentemente dos saberes e demandas de aprendizagem dos alunos, desconsidera as possibilidades de diálogo entre o que a professora pretende ensinar e o modo como as crianças vão explicitando a maneira particular em que constroem conhecimentos.

Assim, ao desconsiderar o que os alunos sabem, o trabalho proposto pela professora caminha em outra direção, o que parece interferir no envolvimento dos alunos com as atividades propostas e na disciplina - ou na falta dela - que se instaura na turma.

\section{f) Ênfase na aprendizagem pela repetição e memorização}

Com a intenção de que os alunos fixem "o correto", durante a entrevista, Raquel explicita uma concepção de ensino prescritivo (que, aliás é compatível com a centralização do professor na sala de aula), sustentado no planejamento de situações que favoreceriam a percepção e a memorização da escrita por meio de exercícios de repetição.

Observamos que, para Raquel, esse é um ponto de conflito, já que ela demonstra não ter clareza sobre o valor e a função da cópia; desse modo, ora afirma não valorizá-la como estratégia de ensino, ora alega seu valor, como ocorreu ao explicar que: "a cópia ajuda a melhorar a letra, que tem que ficar adequada, mas não ensina. Copiar as frases do que tem que fazer é bom (referindo-se às orientações das atividades), mas copiar um texto inteiro não é válido. A não ser quando é um texto curto, que ajuda a aprender as letras do alfabeto. Quando um texto trabalha mais com uma letra, como o V ou o F, por exemplo, ajuda a criança a fixar as letras; daí vale a 
pena copiar e depois o professor pode propor outras atividades ligadas ao texto para ajudar a fixar mais.".

Apesar disso, durante a observação, verificamos como enfatiza a presença desse recurso na maioria das atividades propostas, o que contraria a compreensão de que a aprendizagem da escrita ocorre por meio de construções conceituais, como afirmam Ferreiro e Teberosky (1999, p. 37):

Quando se encara a escrita como uma técnica de reprodução do
traçado gráfico ou como um problema de transcrição de regras de
transcrição do oral, se desconhece que, além do aspecto perceptivo-
motor, escrever é uma tarefa de ordem conceitual. Portanto, se bem
que seja necessária a presença de modelos - enquanto ocasião de
desenvolvimento dos conhecimentos - a escrita não é cópia passiva,
e sim interpretação ativa dos modelos do mundo adulto. Longe da
caligrafia e da ortografia, quando uma criança começa a escrever,
produz traços visíveis sobre o papel, mas, além disso, e
fundamentalmente, põe em jogo suas hipóteses acerca do próprio
significado da representação gráfica.

\section{g) Distanciamento da escrita como efetiva prática social}

A ideia da escrita como prática social, que tem como decorrente o princípio pedagógico de aproximar o ensino dos propósitos é um consenso entre diversos autores (COLELLO, 2010, 2012, 2015, 2017; FERREIRO, 2001b; LERNER, 2002; WEISZ; SANCHEZ, 2002; SOARES, 1998; SMOLKA; NOGUEIRA, 2008) que o ensino da língua escrita deve incorporar as cotidianas de uso da língua.

Na prática, isso significa não só abrir a escola para os usos sociais cada vez mais articulados aos objetivos escolares, mas também superar a mediocridade do ensino centrado nas letras, admitindo de uma vez por todas a complexidade dessa aprendizagem. (COLELLO, 2010, p. 109)

Durante a entrevista, Raquel reafirma essa concepção, apontando a escrita como efetiva prática social e, ainda, se preocupa em explicar seu papel na vida cotidiana, posição que vai ao encontro da importância do letramento concomitantemente à compreensão do funcionamento do sistema alfabético.

No entanto, as atividades de língua observadas em sala de aula mostraram-se, na maior parte, artificiais e pouco relacionadas às funções sociais da língua, tal como ilustram os exemplos das Figuras 27 e 28: tarefas fundamentadas na aprendizagem 
da mecânica da escrita, e não em seus usos sob diferentes contextos e situações comunicativas.

Figura 27 - Atividade 19.1

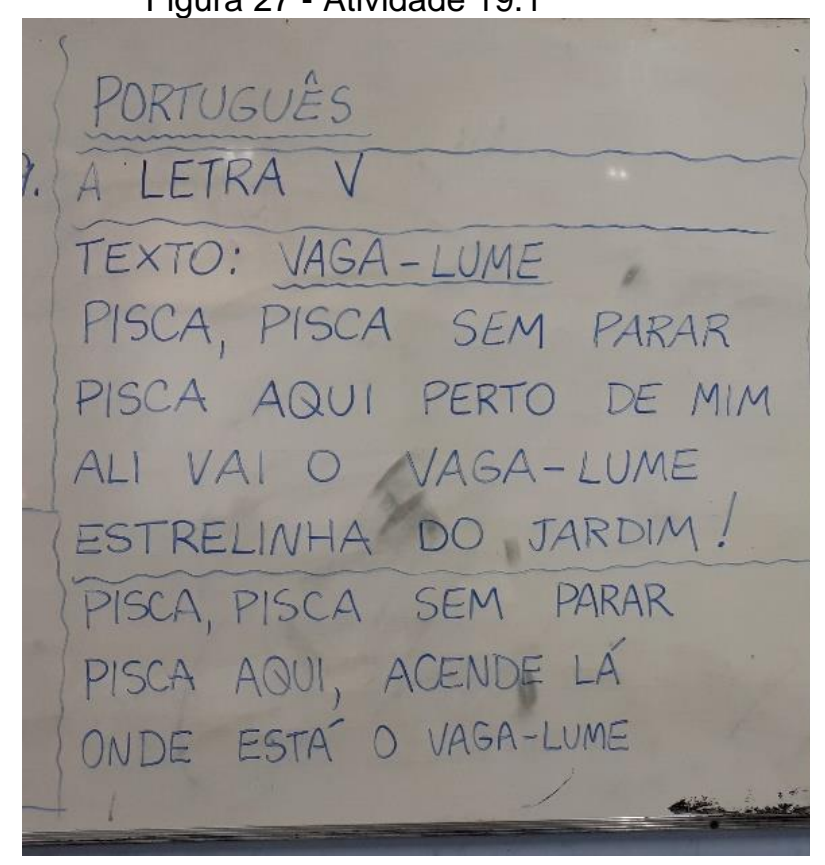

Figura 28 - Atividade 22

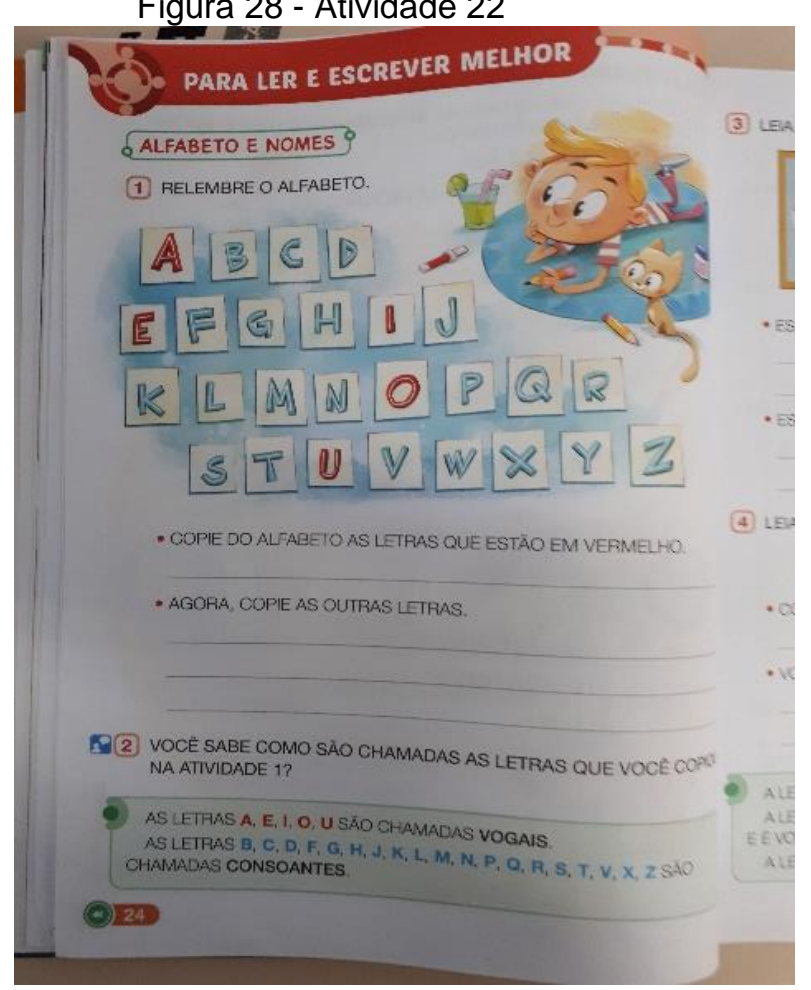

Observamos que, nas duas propostas, o propósito comunicativo se distancia de sua função social, uma vez ambas pressupunham a cópia e destinavam-se apenas à correção da professora, que visava treinar a escrita isolada de letras pela diferenciação vogais e consoantes (como se deu na tarefa 22) e enfatizar a escrita correta de palavras (como se deu na tarefa 19.1). Como ocorreu em outras circunstâncias, nestas, trata-se de uma prática pedagógica sustentada na escrita mecânica garantida pela cópia, em que a produção escrita estava distante das situações sociais de uso da língua.

\section{h) Ênfase nos aspectos notacionais da escrita}

Considerando as 15 atividades de escrita observadas, verificamos que 13 referiam-se a aspectos notacionais, predominando tarefas associadas às características da representação gráfica da linguagem, mais especificamente, ao sistema de representação convencional da escrita alfabética. O Quadro 22, a seguir, identifica tais prevalências: 
Quadro 22 - Aspectos notacionais priorizados nas atividades de escrita

\begin{tabular}{|l|c|c|}
\hline \multicolumn{1}{|c|}{ Conteúdo trabalhado } & Escrita de & Atividade \\
\hline Ordem alfabética & Letras & 15 \\
\hline \multirow{2}{*}{ Distinção consoante e vogal } & Letras & 22 \\
\hline Segmentação entre palavras & Palavras & $21,22.2$ \\
\hline Letras específicas & Palavras & $26.1 \mathrm{a}, 26.1 \mathrm{~b}$ \\
\hline \multicolumn{2}{|c|}{ Palavras } & 24.1 \\
\hline Consciência fonológica & Textos & $14.1,19.1$ \\
\hline Reflexão sobre o sistema alfabético & Frases/Versos & 20.1 \\
\cline { 2 - 3 } $\begin{array}{l}\text { Reflexão sobre características } \\
\text { textuais de gênero }\end{array}$ & Palavras & 17 \\
\hline Total de atividades - & Texto & $18,27.2$ \\
\hline
\end{tabular}

Fonte: elaborado pela pesquisadora

Em relação aos aspectos notacionais abordados, destacamos algumas proposições para favorecer a compreensão sobre como foram encaminhadas.

Em quatro atividades, o que orientava a escrita eram as letras. Nestas, o foco se alterava, ora com ênfase na ordem alfabética (15), ora na distinção consoante e vogal $(21,22,22.2)$.

$\mathrm{Na}$ atividade 17 os alunos procederam à escrita de um texto memorizado, onde poderiam dedicar-se à reflexão sobre o sistema alfabético. Esta teria sido uma boa oportunidade para que pudessem escrever segundo as próprias hipóteses, mas várias crianças deixaram de usufruir do trabalho por não terem garantido a memorização da cantiga a ser escrita.

As atividades 16 (escrita de uma lista de coisas para levar à praia), 18 (bilhete para João e Maria) e 25 (escrita de palavras a partir de figuras) propunham aos alunos escrever espontaneamente, isto é, segundo as próprias hipóteses; porém, devido à ausência de intervenções que pudessem ajudá-los a refletir sobre o que e como desejavam escrever, nem todos os alunos puderam se envolver e desfrutar do trabalho.

Destacamos a atividade 27.2, na qual as crianças deveriam copiar a descrição e comparação do lobo a partir de dois contos diferentes. Essa descrição foi realizada coletivamente antes, em grande grupo, quando a professora foi escriba da turma, que Ihe ditava o que escrever. Ao longo da proposta, foi possível observar que o que foi escrito pela professora não era exatamente o que era ditado pelos alunos, e ao escrever, ela fazia correções gramaticais e sintáticas, sem compartilhá-las junto aos 
ditantes. Observamos que os alunos, ao copiarem posteriormente a escrita da professora, não tinham clareza sobre os acertos realizados.

Apenas duas atividades (18 e 27.2), que favoreceriam a observação dos alunos sobre a dimensão discursiva da língua, não se concretizaram na amplitude de suas possibilidades pedagógicas pela ausência de intervenções didáticas no encaminhamento das propostas.

\section{i) Fragilidade na exploração e uso dos gêneros textuais}

Durante a observação em sala, foi possível observar que, em alguns momentos, as tarefas de escrita foram atreladas a determinados gêneros textuais, como as listas $(16,21,22.2,24.1,26.1 \mathrm{a})$ e os bilhetes (18).

Como se vê na Figura 29, a seguir, apenas na atividade 16 (escrever uma lista de coisas que as crianças precisam quando vão à praia) houve a proposta explícita de escrita de uma lista com efetivo propósito social.

Figura 29 - Atividade 16 (escrita de lista)

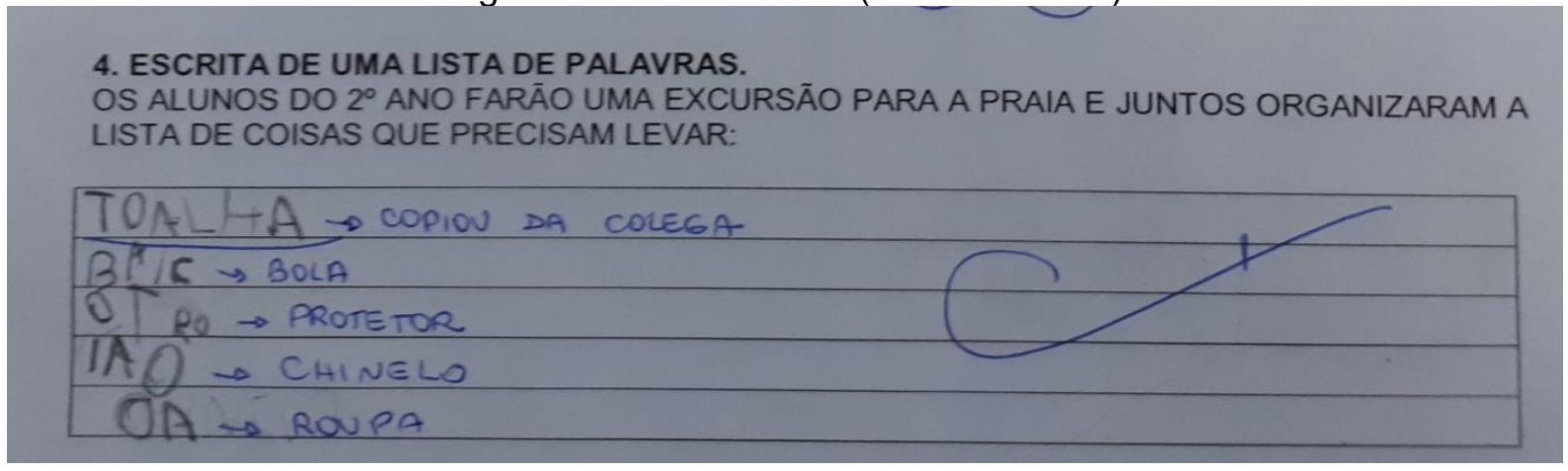

Embora essa atividade seja, em si, potente para explorar a função social desse gênero textual, além de permitir a reflexão sobre a língua, durante a proposição e condução da atividade, não houve intervenções que repertoriassem os alunos sobre esse texto como prática social, o que tornou frágil a exploração e o uso da proposta de trabalho. Podemos supor que a atividade, do ponto de vista da professora, parecia ser tão óbvia, que ela, exceto pelo desafio do notacional, não considerou que pudesse explorar as perspectivas do contexto e do propósito no trabalho junto aos alunos. Por isso, nem todas as crianças puderam se envolver com a proposta.

Nas demais atividades, os alunos produziam também outras listas, mas sem ter conhecimento de que o faziam, ou por que e para quem. 
Foi o que ocorreu, por exemplo, com as palavras da rotina, escritas diariamente junto ao cabeçalho, proposta ilustrada a seguir. Segundo ambas professoras, essa prática favorece a aprendizagem da escrita, pois "ajuda a gravar as letras das palavras", "ensina a desenhar melhor as letras", "faz com que as crianças prestem mais atenção no jeito certo de escrever as palavras". Algumas variações se fazem presentes entre as salas, como acrescentar ou não itens ao cabeçalho ou posteriormente a ele, como o dia da semana, a previsão do tempo, a escrita do alfabeto ou os números de 1 a 30 :

Figura 30 - Escrita de cabeçalho e rotina

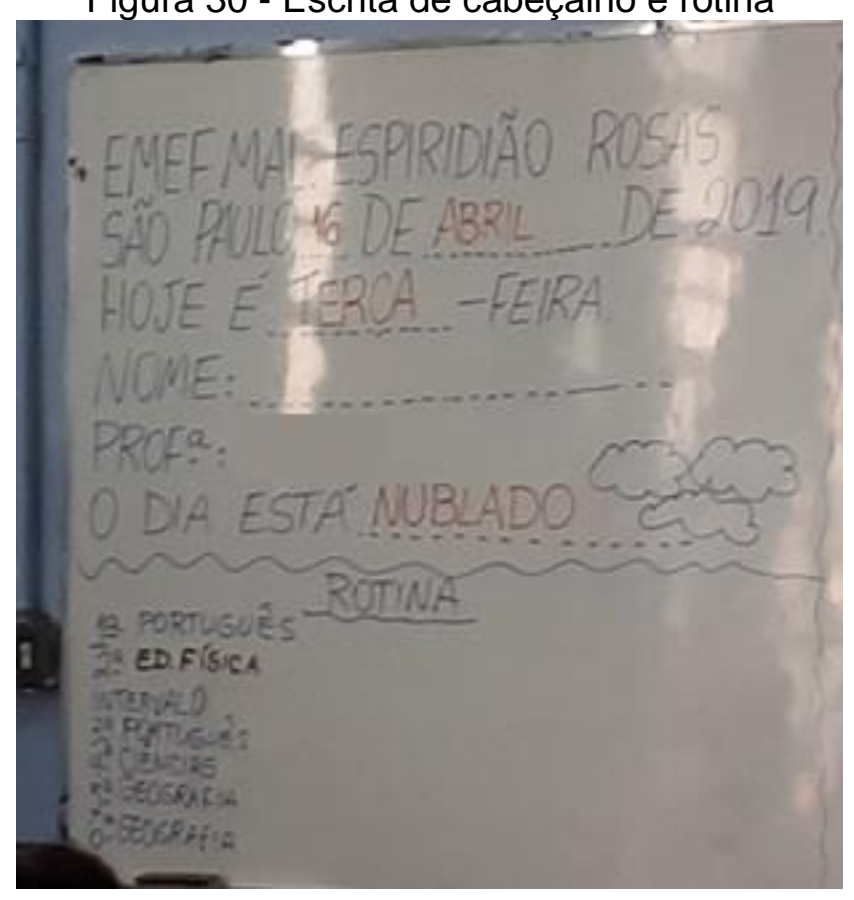

As duas professoras apontam que a rotina descrita na lousa tem por objetivo situar os alunos sobre o que farão ao longo do período letivo; no entanto, observa-se que não há socialização do escrito, limitando-se esta prática a uma atividade de cópia. Como se vê na Figura 31, a seguir, nas duas classes verifica-se também que, em geral, a nomenclatura utilizada diz respeito às áreas disciplinares, e não necessariamente, aos momentos da rotina: 
Figura 31 - Escrita da rotina

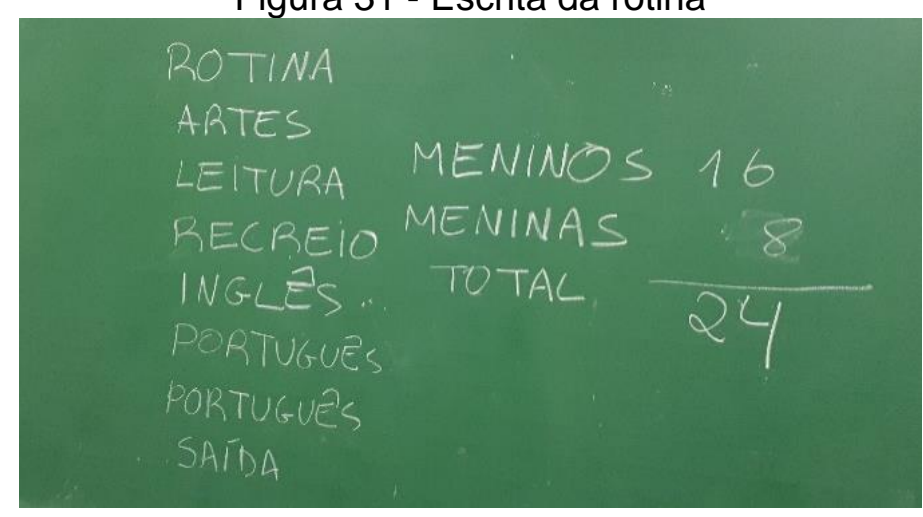

Vale apontar ainda a suposição da docente de que, ao disponibilizar textos pela sala, ela estaria promovendo um ambiente alfabetizador, um estímulo à leitura, pela disponibilização de materiais gráficos aos alunos. No entanto, o que define um ambiente alfabetizador não é somente a presença de textos em classe, e sim o grau de significado e de uso que estes têm na relação com os alunos, constituindo-se para eles fonte de consulta valiosa, tanto para a compreensão do funcionamento do sistema de escrita, quanto para o processo de letramento. A esse respeito, afirmam Weisz e Sanchez (1999):

Cabe, portanto, à escola, garantir a quem precisa, este ambiente alfabetizador. [...] Aqui cabe uma ressalva: é importante frisar que não é o ambiente que alfabetiza, tampouco o fato de pendurar coisas escritas nas paredes que produz por si só um efeito alfabetizador. Essa expressão designa, de maneira condensada, um ambiente pensado para propiciar inúmeras interações com a língua escrita, interações mediadas por pessoas capazes de ler e de escrever. (WEISZ; SANCHEZ;1999, p. VIII)

Outros gêneros textuais podem ter uma presença marcante na escola, desde que tenham uma clara função social e apresentam uma estrutura textual apropriada ao trabalho durante a alfabetização. Cartas e bilhetes, por exemplo, prestam-se muito bem a esse propósito.

Assim como a professora do primeiro ano, Raquel lança mão dessa proposta na atividade 18, quando os alunos foram convidados a produzir um bilhete fictício para alertar João e Maria sobre a casa de doces da bruxa, uma armadilha preparada para capturá-los, como se vê na Figura 32, a seguir: 
Figura 32 - Atividade 18 (escrita de bilhete)

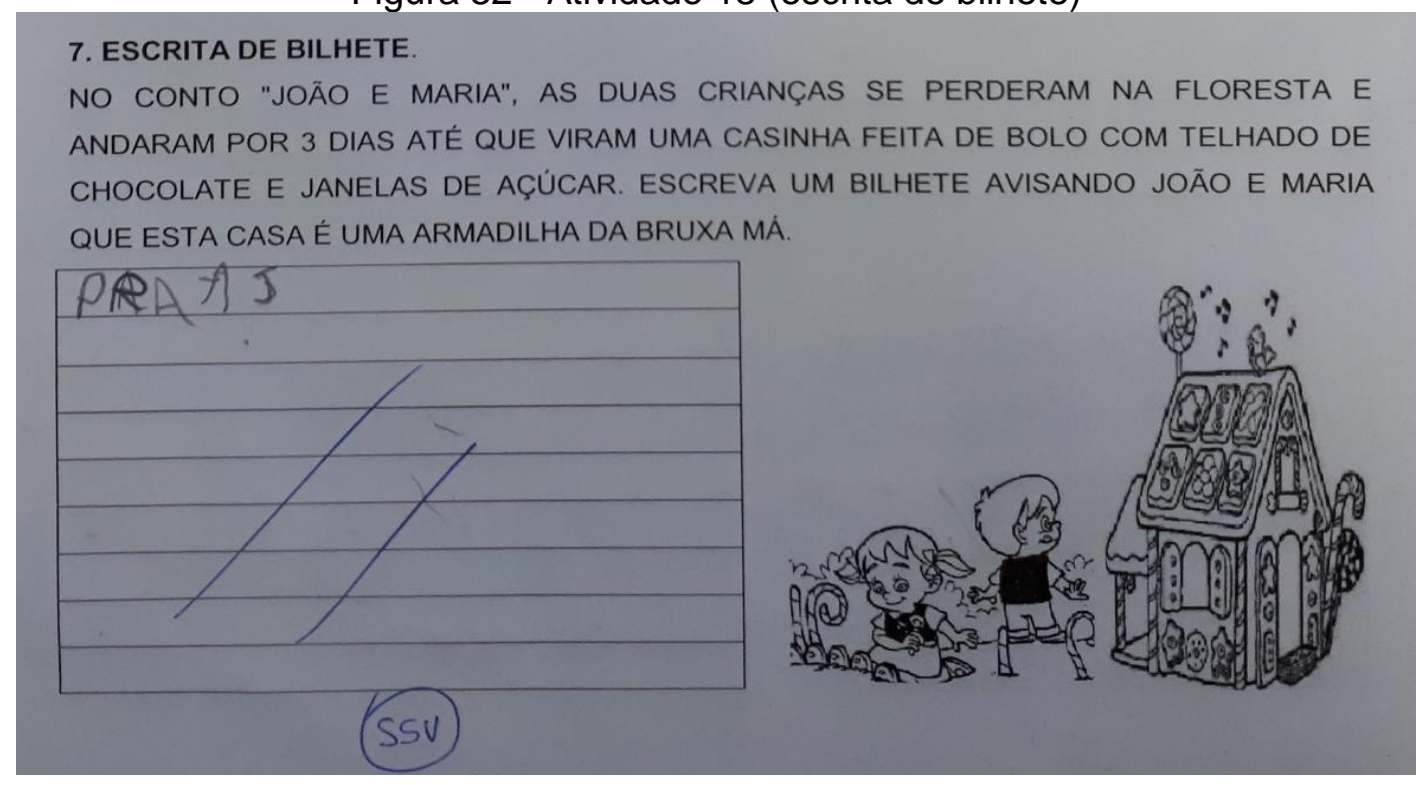

Embora a produção em contexto fictício pudesse ser justificada, as condições básicas do "alfabetizar letrando" - propósito comunicativo, interlocutores explícitos além da reflexão sobre o sistema - não foram assimiladas na proposta de trabalho, já que o texto referência não havia sido bem compreendido, assim como a consigna sobre o que escrever. Dessa forma, embora a proposição fosse potente, sua realização mostrou-se frágil na exploração e uso do gênero, e muitas crianças ficaram perdidas, não chegando a se envolver com a tarefa. Em função disso e do pouco apoio para as crianças com mais dificuldade, algumas se arriscaram sem muita efetividade,

A partir do exemplo, é possível depreender como diversos modelos de atividades foram sendo incorporados pela professora sem a mediação adequada para que os alunos pudessem fazer o trabalho maximizando as possibilidades de reflexão, aprendizagem e envolvimento com a língua.

\section{j) Abordagem da consciência fonológica pela relação grafema-fonema}

Consoante à professora do primeiro ano, Raquel afirma a percepção e a discriminação fonêmica como bases para a alfabetização, bem como sua correta relação com a grafia das letras. 
Segundo essa concepção, a escrita é concebida como um código a ser aprendido pela relação letra-som, de modo que seja possível apreender a escrita pelos processos de codificação e decodificação. Ou nas palavras de Miranda (2008, p. 2):

\begin{abstract}
A simples aplicação de cartilhas, de livros didáticos ou de métodos pré-definidos não garante a aprendizagem dos alunos. É o caso dos chamados métodos sintéticos (alfabético, fônico e silábico) que centram o ensino nas partes que compõem as palavras (letras, sons e sílabas), privilegiando o processo de codificação e decodificação, assim como a redundância sem sentido de palavras e frases descontextualizadas. Nessa perspectiva, a aprendizagem é considerada como resultado do acúmulo de informações e não como reorganização e reestruturação dos conhecimentos disponíveis. Da mesma forma, os interesses e a realidade cognitiva, emocional e social dos alunos são desconsiderados, como se eles não tivessem noções e hipóteses acerca do funcionamento da língua.
\end{abstract}

Apesar das inúmeras críticas feitas aos métodos de alfabetização (FERREIRO; TEBEROSKY, 1986; FERREIRO, 2001b; GERALDI, 1997; COLELLO, 2015; LERNER, 2002; SOARES, 2017; WEISZ; SANCHEZ, 2002; MORTATTI, 2004), a professora parece se enquadrar nessa forma de trabalho. De fato, ela relata planejar e encaminhar o processo de ensino da língua seguindo a lógica que caminha "do mais fácil ao mais difícil", e explica: "O professor precisa trabalhar o som de cada letra, e não pela ordem alfabética, mas começando pelas vogais. Depois, mostra os pedaços de palavra e o texto.".

Nas observações em classe, pudemos constatar que essa dinâmica linear de ensino nem sempre se concretizou na progressão de propostas de escrita feitas aos alunos, as quais abordavam ora o conhecimento sobre as letras, ora as palavras e os textos em sucessão aleatória; não foram observadas atividades que partiam ou exploravam sílabas. De qualquer forma, sua prática pedagógica mostrou-se distante das proposições dos referidos autores e até mesmo dos princípios do Currículo da Cidade.

\title{
k) Fragilidade na abordagem integrada dos contextos linguísticos
}

Durante a entrevista, Raquel não fez menção às modalidades linguísticas presentes no trabalho com a linguagem. Em princípio, a relação entre leitura, escrita e oralidade não parecia ser um foco de preocupação assumido no plano pedagógico. 
Observamos, no entanto, que em diversas propostas de escrita, a professora buscava articulação entre esses contextos, prevalecendo o encadeamento entre a leitura e a escrita (como nas atividades 14- 14.1-14.2, 19-19.1-19.2, 20-20.1-20.2, 22.1-22.2, 24-24.1). Nessas ocasiões, a escrita foi proposta como um desdobramento da leitura, de modo que o conteúdo do que seria escrito estava a ela vinculado. Tratava-se, pois, de um modo de contextualizar a tarefa, o que é uma iniciativa válida e recomendada tanto pelos pesquisadores (GERALDI, 1997; TEBEROSKY, TOLCHINSKY, 1997; LERNER, 2002; COLELLO, 2012). Em apenas uma das situações, ilustrada a seguir, foi possível ver a articulação entre leitura, oralidade e escrita (27-27.1-27.2).

\section{Figura 33 - Atividade 27}

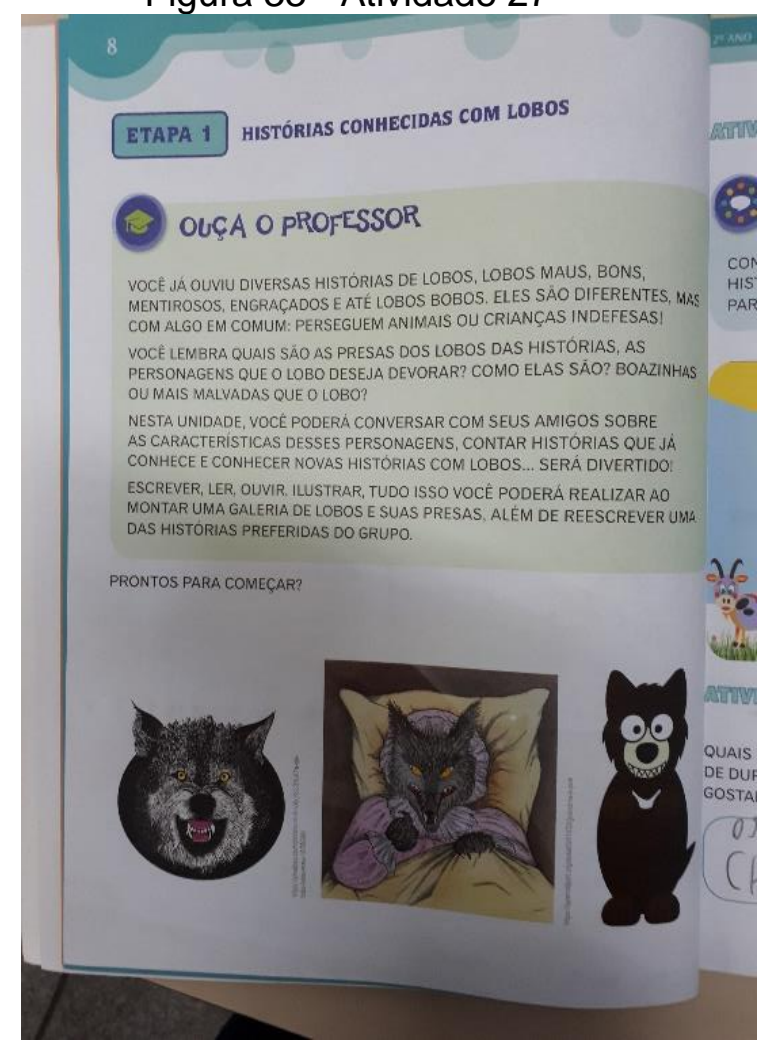

Figura 34 - Atividade 27.1

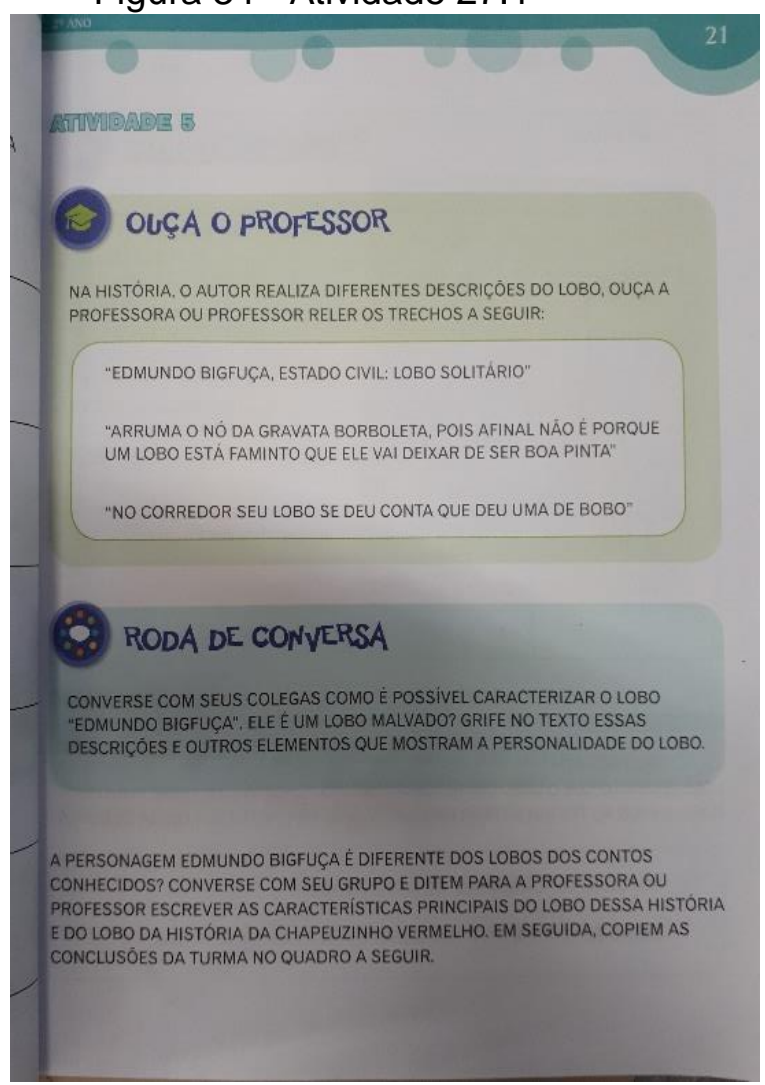


Figura 35 - Atividade 27.2

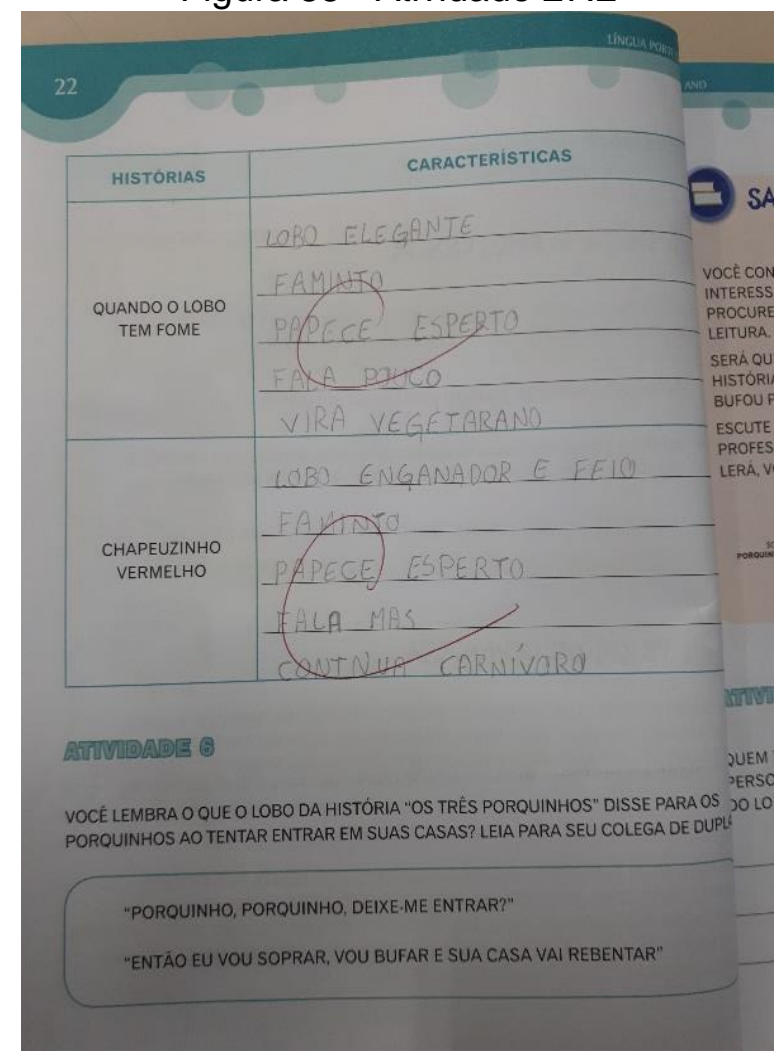

Faz-se importante destacar, contudo, que assim como na classe de primeiro ano, apesar da visível relação entre dimensões linguísticas nas situações de ensino, as manifestações de leitura e oralidade que precederam a escrita constituíram, na verdade, um pretexto para que os alunos se pusessem a escrever, não havendo uma articulação real entre a produção escrita e as situações comunicativas que as produziram.

\section{I) Incompatibilidade entre as perspectivas de aprendizagem e a condução}

\section{das propostas}

No âmbito discursivo, Raquel aponta que a aprendizagem está ancorada em processos reflexivos, bem como na maturidade e nas aptidões que permitiriam ao aluno avançar no conhecimento.

Ao longo da observação das práticas, verificamos que, apesar de Raquel manifestar a intenção de acompanhar os alunos por meio de intervenções produtivas, isto é, que favorecessem processos de reflexão, ela, na maioria das vezes, ocupavase mais de oferecer-Ihes informações, atuando para que estas fossem "guardadas na mente das crianças". 
Tal dinâmica revela como a intervenção pedagógica nem sempre favorece a construção cognitiva, especialmente quando incorre em mecanismos de pura memorização.

Observamos, assim, incoerências entre os objetivos de aprendizagem calcados na construção de conhecimentos por parte dos alunos e as práticas de Raquel, apoiadas em práticas prioritariamente diretivas e transmissivas.

\section{m) Preocupação com o controle da disciplina}

Ao longo da observação, era visível a expectativa de Raquel (a mesma de Bianca) de que as crianças a ouvissem com atenção e seguissem suas orientações na realização das atividades; contudo, isso poucas vezes ocorreu, uma vez que a turma se mostrava bastante agitada e pouco interessada pelo que era trazido pela professora. De fato, justamente por dialogarem com suas necessidades de aprendizagem, as atividades pareciam pouco significativas, não merecendo grande investimento das crianças.

Pouco engajados com a própria aprendizagem, notamos que os alunos se dirigiam à professora apenas quando precisavam de alguma orientação específica para seguir a atividade, ou para tirar dúvidas a respeito dela. Com pouca iniciativa, elas demonstravam baixo protagonismo e pouca disposição para escrever por si mesmos, bem como para participar das aulas socializando ideias.

A professora, por sua vez, empenhava-se para manter a disciplina, compreendida aqui como obediência e respeito às regras, e não como organização para o trabalho. Desse modo, constantemente, pedia-Ihes silêncio, chamava sua atenção e solicitava que colaborassem com ela, "que já estava cansada de tanto ter que repetir as mesmas coisas todo o tempo".

Entendemos ser importante apontar a relevância da disciplina como organização do grupo e de cada criança para o trabalho, e não como a imposição do silêncio, da passividade e da submissão sujeitada à autoridade do professor.

Isso porque o cumprimento de regras decorre da compreensão de porque é importante segui-las, e não da cega imposição do professor ao aluno.

Tal consideração desloca o lugar do professor, que deixa de exercer as funções de controle e punição para assumir o papel daquele que propõe desafios cognitivos adequados, enquanto coordena e media as situações de aprendizagem, de modo que 
os alunos possam desenvolver a autorregulação e a consciência ética, ao mesmo tempo em que trabalham e estudam.

Vinha e Tognetta (2009, p. 4) contribuem com essa reflexão, afirmando que

Ao relacionarmo-nos uns com os outros, é imprescindível a existência de regras que visam garantir a harmonia do convívio social. Aliás, as regras só existem em função da convivência humana e da necessidade de regulá-la. Contudo, para Piaget, o importante não são as normas em si, mas sim, o porquê as seguimos. [...]-Desta forma, o valor moral de uma ação não está na mera obediência às regras determinadas socialmente, mas sim no princípio inerente a cada ação. (VINHA; TOGNETTA, 2009, p. 4)

No caso, as normas e os combinados com o grupo deveriam estar a serviço do bom desenvolvimento do trabalho e do respeito ao trabalho dos colegas de um modo coerente com o interesse e o envolvimento nas tarefas, e não como um pré-requisito ou disposição paralela.

\section{n) Fracasso escolar justificado pelos aspectos extraescolares}

Ao comentar sobre as razões do fracasso escolar, a professora aponta a quantidade de faltas de alunos, além do parco acompanhamento de suas famílias, que não vêm às reuniões pedagógicas, não os ajudam nas lições de casa, não verificam seus cadernos, nem os acompanham nos estudos, deixando de responder suas dúvidas quando não sabem algo. Logo, esses alunos não se envolvem com a aprendizagem, uma vez que ninguém exige que se comprometam com a escola. Segundo ela, na idade em que seus alunos se encontram, é esperado que só se interessem pelo conhecimento se os pais ou responsáveis cobrarem deles participação e envolvimento. A mesma concepção foi identificada nas práticas docentes, direcionadas à cobrança, de alunos e famílias, pelo sucesso dos processos de aprendizagem.

Acrescenta que algumas crianças têm problemas de saúde, como de visão e audição, e os pais não tomam providências para resolver o problema. Diz também que há crianças que sofrem de anemia e estão permanentemente cansadas, sem energia, o que interfere em suas condições de aprendizagem. A esse respeito, entendemos que seu apontamento faz sentido apenas na perspectiva de que o indivíduo percebe o objeto de conhecimento e o apreende pela discriminação e memorização, o que corrobora para uma concepção empirista de ensino e aprendizagem. 
Em sua perspectiva, os alunos que não têm problemas de saúde poderiam avançar mais na aprendizagem se fossem acompanhadas individualmente no horário regular de aulas, o que seria possível se as professoras do segundo ano pudessem contar com uma professora estagiária, como ocorre no primeiro ano. Sobre essa observação, apontamos como essa situação pode ser contraproducente se representar a possibilidade de haver terceirização dos alunos com dificuldades de aprendizagem.

Chama nossa atenção que, indo além da assiduidade discente, a professora entenda que os alunos somente se envolvem com a aprendizagem se forem cobrados por isso, não aventando a possibilidade de que conhecer, por si só, seja objeto de desejo pelo empoderamento que permite ao aprendiz.

\subsection{Interação no $2^{\circ}$ ano}

Entre as concepções assumidas e as posturas em sala de aula indicadoras de princípios implícitos, é possível destacar os seguintes aspectos:

\section{a) Interação como vínculo afetivo}

Durante a entrevista, ao declarar a importância atribuída às interações para o ensino, Raquel, assim como sua colega Bianca, revela a importância do estabelecimento de vínculos afetivos como elemento favorecedor da aprendizagem, vínculos estabelecidos como forma de respeito (e não de medo).

Em consonância com a valorização de Raquel da interação afetiva, entendemos o seu papel na promoção da aprendizagem, já que os vínculos de confiança e proximidade fomentam o desejo de aprender. Nas palavras de Davis e Oliveira (2010, p. 105):

O afeto pode, assim ser entendido como a energia necessária para que a estrutura cognitiva passe a operar. E mais: ele influencia a velocidade com que se constrói conhecimento, pois, quando as pessoas se sentem seguras, aprendem com mais facilidade. (DAVIS; OLIVEIRA, 2010, p. 105)

No entanto, ao longo da observação, ficava evidente certo distanciamento entre professor e alunos, que não pareciam compartilhar metas e procedimentos de trabalho, ao mesmo tempo em que pouco se ouviam em suas necessidades e 
possibilidades de atuação. Queixas da professora quanto à agitação e desinteresse da turma eram frequentes, ao mesmo tempo em que era possível ver também que professora buscava mais o controle e a punição, do que propriamente uma relação afetiva. O vínculo dos alunos com o conhecimento era frágil, uma vez que as propostas didáticas nem sempre faziam sentido estando pouco vinculadas à sua vida. A esse respeito, vale lembrar a afirmação de Davis e Oliveira (2010, p. 107) de que "o trabalho intelectual feito sobre materiais ou conteúdos significativos é sempre mais produtivo do que aquele envolvendo conteúdos ou materiais sem nenhuma significação para quem aprende."

A mesma tensão se apresentava na relação entre os alunos, que viviam muitos conflitos entre si. Constituída por pequenos subgrupos, a turma não conseguia se unir e várias crianças pareciam disputar espaço e atenção na relação com Raquel pela provocação e pela indisciplina.

Nesse processo, os alunos pareciam ter papeis marcados, reconhecidos inclusive pela professora, o que thes conferia um lugar no grupo: os bagunceiros, os provocadores, os mais bem comportados etc.

Chamou nossa atenção a pouca escuta entre professor e alunos e deles entre si: era comum ver todos falando ao mesmo tempo, de diferentes assuntos, bem como subir a voz para ser ouvido, posição que se alternava entre a professor e os alunos. De fato, os únicos momentos em que a professora conseguia ser ouvida ocorriam sob ameaça de perda do recreio ou de uma conversa com a mãe do aluno, o que tinha efeito momentâneo, e evidenciava como a comunicação produtiva não se estabelecia.

Frente a esse cenário, é possível constatar inconsistência entre o discurso de Raquel - que valoriza a relação entre afetividade e aprendizagem - e suas práticas em sala de aula, as quais tendem a caminhar em direção oposta ao que se propõe.

\section{b) Interação eficiente apenas fora do contexto de ensino}

Durante a entrevista, Raquel afirma entender que a interação entre professor e alunos é mais efetiva nas situações em que podem tratar da vida cotidiana, quando discutem assuntos diversos, o que não é possível quando estudam a língua. Explica que "os assuntos de ciências" permitem um diálogo mais efetivo, posto que muitas vezes tratam da vida corriqueira das pessoas, e complementa que o mesmo só ocorre 
nas aulas de Língua Portuguesa quando a professora lê alguma história aos alunos que trate de temas dessa natureza.

Consoante com sua declaração, ao longo da observação, verificamos que Raquel parecia pouco conectada aos alunos enquanto orientava o trabalho ou expunha algo que esperava que aprendessem. Assumindo um tom mais "professoral", permanecia distante, o que era aliviado nos momentos mais descontraídos, quando se aproximava dos alunos mais efetivamente, ao comentarem, por exemplo, situações e experiências da vida pessoal.

Assim, foi possível detectar uma concepção implícita de que a aprendizagem de conteúdo e, particularmente a reflexão sobre a língua pouco se articulam com a interação e a afetividade. Observamos aí uma cisão minimamente curiosa se entendemos que não há separação na vida da criança quando está dentro e fora da escola, quando está aprendendo ou quando está se relacionando com os outros. Pelo contrário, justamente por constituir-se holisticamente, é mais fácil para a ela transitar entre os diversos espaços de convivência.

\section{c) A interação pela competição}

Assim como se deu na turma de primeiro ano, também na classe do segundo ano se faz presente a crença de que os alunos se dispõem mais e melhor quando se comparam a um colega mais avançado na aprendizagem.

Durante a entrevista, Raquel afirma que "ver que um colega leu mais, ou sabe mais" estimula os alunos a quererem aprender mais, para poderem depois trocar impressões e fazer comentários.

A motivação aparente parece ser o desejo de equiparação entre indivíduos por aquilo que sabem, o que Ihes conferiria algum status frente ao professor.

Como já dito no capítulo 9 , entendemos que essa leitura provoca um desvio nas reais motivações que guiam a relação com o saber, que quando construído cooperativamente, provoca a realização do aprendiz pela própria natureza dos atos de conhecer, cooperar, construir coletivamente e partilhar informações, estabelecendo efetivas parcerias. 


\section{d) Divisão da turma em dupla/grupos conforme a competência dos alunos}

Conforme já foi dito, sabemos que uma possibilidade interessante em sala de aula é o trabalho em duplas e pequenos grupos, desde que oportunizem a coordenação de diferentes pontos de vista para alcançar metas comuns. A esse respeito, esclarecem Davis e Oliveira (2010, p. 118):

Uma das alternativas mais ricas com que os adultos contam para
amparar e orientar as gerações mais novas é o trabalho
supervisionado em grupo, em que diferentes crianças e jovens
interagem em busca de um objetivo comum, dividindo e
compartilhando esforços. Durante as horas em que passam juntos [...]
os alunos se tornam mais conscientes de si mesmos, aprendem a
ouvir e incorporar críticas às sugestões dadas, a defender suas ideias
e seu espaço no grupo, a dividir tarefas de modo produtivo. (DAVIS;
OLIVEIRA, 2010, p. 118)

Apesar do princípio da parceria em sala de aula ser amplamente difundido, ao longo da investigação em sala de aula, raramente as crianças foram, conforme suas competências, separadas em subgrupos; de fato, apenas da sequência de atividades 26.1a e 26.1b isso ocorreu. Observamos, no entanto, que no caso dessas atividades, essa organização não foi eficaz para promover avanços cognitivos nos alunos, uma vez que ambas consistiam na cópia (de palavras/frases a serem segmentadas).

Como nas demais propostas não houve a divisão dos alunos por competências, poderíamos, logo, supor que a professora considera a heterogeneidade da turma como um fator positivo, capaz de agregar à aprendizagem. No entanto, não é o que se verifica, posto que as atividades de escrita foram realizadas, em sua maioria, ou individualmente, ou em grande grupo, situações em que a heterogeneidade ou não aparecia, ou se diluía no coletivo do grupo classe. Nos dois casos, observou-se que a professora assumia o controle da aprendizagem dos alunos, acompanhando-os, como já dissemos, passo a passo, na orientação das atividades, a fim de que realizassem as propostas do modo mais acertado.

Notamos, no entanto, que em apenas duas ocasiões (atividades 17 e 25) as crianças foram convocadas a trabalhar em duplas. Raquel explica que evita promover esse tipo de agrupamento porque, em vista da agitação do grupo, não tem condições de acompanhar a todos, pois precisa priorizar a disciplina e cumprir o programa previsto. 
Tais acepções, embora implícitas, revelam perspectivas inconsistentes e conflitantes de Raquel, a qual parece ter pouco claro quais estratégias de agrupamento favorecem mais ou menos seus objetivos de ensino e a aprendizagem dos alunos.

\section{e) Predomínio do trabalho individual}

Refletir sobre as diferentes modalidades de organização dos alunos para o trabalho pressupõe considerar os contextos de interação que melhor se adequam aos objetivos de aprendizagem. Assim, em alguns momentos, trabalhar individualmente pode ser mais produtivo do que estar em dupla ou em pequenos grupos, particularmente quando o foco do trabalho exige autorregulação da atenção.

No entanto, os critérios de divisão e organização da turma, assim como o de potencial pedagógico dos agrupamentos, parecem não estar claros para Raquel, razão pela qual predominaram as atividades individuais que, por sua vez, foram pouco otimizadas, conforme ilustra o Quadro 23, a seguir:

Quadro 23 - Organização da turma 2ำ ano

\begin{tabular}{|c|c|c|c|}
\hline Trabalho individual & Trabalho em duplas & $\begin{array}{c}\text { Trabalho em } \\
\text { pequenos grupos }\end{array}$ & Trabalho em grande grupo \\
\hline 13 & 2 & 0 & 0 \\
\hline \multicolumn{2}{|l}{ Total de atividades observadas } \\
\hline
\end{tabular}

Fonte: elaborado pela pesquisadora

Como se vê, os alunos dedicaram-se às propostas predominantemente de modo individual. Assim como ocorreu na classe de primeiro ano, na maior parte do tempo, faziam a mesma tarefa e simultaneamente, situação didática ancorada em princípios de ensino diretivos e empiristas, em que as diferenças individuais são minimizadas e inibidas.

Desse modo, as aulas eram ser centralizadas no professor, e o foco de trabalho tendia mais à realização das tarefas do que aos processos de construção de conhecimentos vivenciados pelos alunos.

As crianças eram desencorajadas a conversar entre si, mesmo quando se tratava de algo relativo à atividade que faziam; a ajuda interpessoal também não era bem vinda, sob a alegação que cada um deveria cuidar da própria tarefa. 
Com a professora ocorria o oposto: por vezes ela transitava entre as crianças, orientando-as e corrigindo-as, e ora se dirigia ao grupo classe como um todo.

Verificamos que, se no âmbito discursivo, Raquel reconhece a importância das interações para a aprendizagem, na prática, privilegia o trabalho individual, dando a entender que este seja o melhor modo de evitar que as crianças se distraiam e deixem de assimilar o que devem aprender.

\section{f) Diálogo nem sempre se constitui como um processo interativo eficiente para a construção cognitiva}

Analisar a relação entre as concepções implícitas e os processos de ensino implica não apenas em verificar as formas de organização e agrupamento em sala de aula, como também observar a qualidade da interação, isto é, a constituição dos processos dialógicos, O Quadro 24 , a seguir, visa explicitar a dinâmica relacional observada.

Quadro 24 - Processos interativos presentes nas atividades de escrita - $2^{\circ}$ ano

\begin{tabular}{|c|c|c|}
\hline $\begin{array}{c}\text { Práticas dialogadas entre } \\
\text { professor e alunos }\end{array}$ & $\begin{array}{c}\text { Práticas dialogadas entre } \\
\text { alunos }\end{array}$ & Práticas não dialogadas \\
\hline 4 & 0 & 11 \\
\hline Total de atividades observadas & & 15 \\
\hline
\end{tabular}

Fonte: elaborado pela pesquisadora

Como se pode ver, prevaleceram situações pedagógicas que não se constituíram pelo foco no diálogo. Ao longo da observação, constatou-se que, de fato, era difícil para Raquel manter uma relação de proximidade com as crianças, já que a conexão entre professor e alunos era marcada mais pela reatividade de ambas as partes: a professora chamava a atenção dos alunos constantemente, enquanto eles continuavam desconsiderando suas solicitações. Observamos também a presença constante de provocações verbais e físicas entre as crianças, que enfrentavam conflitos todo o tempo.

Embora Raquel se mostrasse desconfortável com esse cenário, não parecia à vontade para promover mudanças relevantes na situação; visivelmente desestimulada, dava a impressão de conformidade com o que ocorria, atribuindo a responsabilidade da 
desordem e da inquietação em sala de aula aos alunos, alegando que eram agitados e não a ouviam, o que segundo verificamos, era recíproco.

A ingerência da professora, a qual parecia ter poucos recursos para assumir seu lugar na condução do grupo, acentuava a indisciplina. Desse modo, a relação entre todos era marcada pela baixa escuta, o que impedia o estabelecimento de diálogo e o funcionamento organizado da dinâmica da turma.

A predominância desse clima se acentuava na transição entre as atividades, o que interferia no modo de propor e orientar o trabalho, que demorava a ter início. Quando Raquel conseguia a atenção discente, explicava rapidamente as propostas, as quais eram, na grande maioria, realizadas depois, individualmente, pelos alunos.

Era visível a preocupação da professora em orientar as crianças antes e durante a realização das tarefas; no entanto, ao não assumir a liderança efetiva do grupo, também era difícil para Raquel considerar e acompanhar os processos de construção de conhecimentos das crianças. Assim, era visível o descompasso entre a proposição das atividades e as demandas ou os interesses dos alunos.

Nos poucos momentos pautados pelo diálogo entre professor e alunos, Raquel buscava instrui-los sobre as tarefas a realizar, especificamente, não havendo possibilidades reais de troca de ideias. Desse modo, as quatro situações observadas em que a professora e os alunos interagiram (duas individualmente e duas em duplas) evidenciaram a dificuldade de interação dialógica no grande grupo.

Juntas, a prevalência dos trabalhos individuais e a fragilidade das trocas cognitivas entre professora e alunos ou entre colegas pode, como se sabe, prejudicar o avanço na aprendizagem.

Trazer a relevância do diálogo como condutor da prática pedagógica exige rever o lugar e a atuação docente, pois entendemos que Raquel teria que assumir seu papel de referência no processo educativo e, ao mesmo tempo, legitimar a voz dos alunos como seres pensantes, isto é, como sujeitos capazes de assumir maior autonomia no processo de aprendizagem. Possivelmente, esse seria um bom caminho para conseguir alcançar uma relação, de fato, dialógica com seus alunos. 


\section{CONCLUSÃO}

Tendo eleito o ensino da língua escrita como objeto de investigação, partimos da hipótese de que as práticas de ensino e as dinâmicas interativas propostas em aula são, consciente ou inconscientemente, tributárias de concepções docentes.

A fim de verificar tal pressuposto, com base no mapeamento das situações de escrita do $1^{\circ}$ e $2^{\circ}$ anos do Ensino Fundamental de uma escola pública do município de São Paulo, pretendemos conhecer as concepções docentes sobre a língua e seu ensino, compreender os mecanismos de transposição didática que alicerçam a prática docente e conhecer a natureza das interações em sala de aula, bem como suas possibilidades de contribuição para a aprendizagem.

A partir dos dados obtidos, foi possível constatar diferenças individuais marcantes na especificidade de cada uma das professoras observadas, o que evidenciava sua singularidade no modo de estabelecer as relações em sala de aula e a construção de conhecimentos por parte dos alunos. Tal constatação, de acordo com PENIN (2009), levou-nos a observar o modo como cada professora assume e concretiza a sua profissionalização (conjunto de iniciativas de formação) e profissionalidade (o modo como, em uma perspectiva subjetiva assimila a formação), isto é, sua "personalidade pedagógica". Pressupomos que a disponibilidade de cada uma perante sua turma, atrelada à referenciais mais ou menos constituídos, produzem marcas que imprimem diferentes caminhos na condução do trabalho pedagógico junto aos alunos.

Em sala de aula, tanto Bianca, quanto Raquel mostraram-se muito comprometidas com a aprendizagem de seus alunos e se empenhavam na proposição de tarefas capazes de fazê-los avançar. Contudo, enquanto Bianca era uma referência de autoridade na condução do processo pedagógico, Raquel apresentava dificuldade em assumir o lugar de condutora do grupo, o que interferia na convivência e na aprendizagem dos alunos.

Bianca demonstrou segurança e firmeza tanto no âmbito discursivo, quanto na condução do processo educativo em sala de aula. Raquel, no entanto, fez observações relevantes no âmbito discursivo, mas mostrou-se desestimulada e pouco segura sobre o modo de conduzir o trabalho em sala. 
Ao compararmos as concepções e práticas docentes, verificamos pontos de convergência e de divergência nos eixos de análise propostos no presente trabalho, que aparecem sintetizados no seguinte quadro ${ }^{36}$ :

Quadro 25 - Comparação entre concepções e práticas docentes - $1^{\circ}$ e $2^{\circ}$ anos

\begin{tabular}{|c|c|c|}
\hline & 1 ANO (Bianca) & 2 ANO (Raquel) \\
\hline LÍNGUA & $\begin{array}{l}\text { Valorização da escrita como prática } \\
\text { social } \\
\text { Valorização da escrita como meio de } \\
\text { comunicação } \\
\text { Valorização da escrita em detrimento } \\
\text { de outras práticas de linguagem }\end{array}$ & $\begin{array}{l}\text { Valorização da escrita como prática } \\
\text { social } \\
\text { Valorização da escrita como meio de } \\
\text { comunicação e de socialização } \\
\text { Escrita como perpetuação da } \\
\text { memória } \\
\text { Escrita como possibilidade de } \\
\text { exercício da cidadania }\end{array}$ \\
\hline APRENDIZAGEM & $\begin{array}{l}\text { Fragilidade na articulação entre } \\
\text { afetividade e cognição } \\
\text { Professor como centro do processo } \\
\text { pedagógico } \\
\text { Pouca clareza sobre as } \\
\text { necessidades de aprendizagem dos } \\
\text { alunos } \\
\text { Distanciamento de uma perspectiva } \\
\text { de aprendizagem reflexiva } \\
\text { Ênfase na aprendizagem por } \\
\text { repetição e memorização } \\
\text { Distanciamento da escrita como } \\
\text { efetiva prática social } \\
\text { Fragilidade na exploração e uso dos } \\
\text { gêneros textuais } \\
\text { Ênfase nos aspectos notacionais da } \\
\text { escrita } \\
\text { Ensino como controle do processo de } \\
\text { aprendizagem consciência } \\
\text { Abordagem da } \\
\text { fonológica pela relação grafema- } \\
\text { fonema }\end{array}$ & 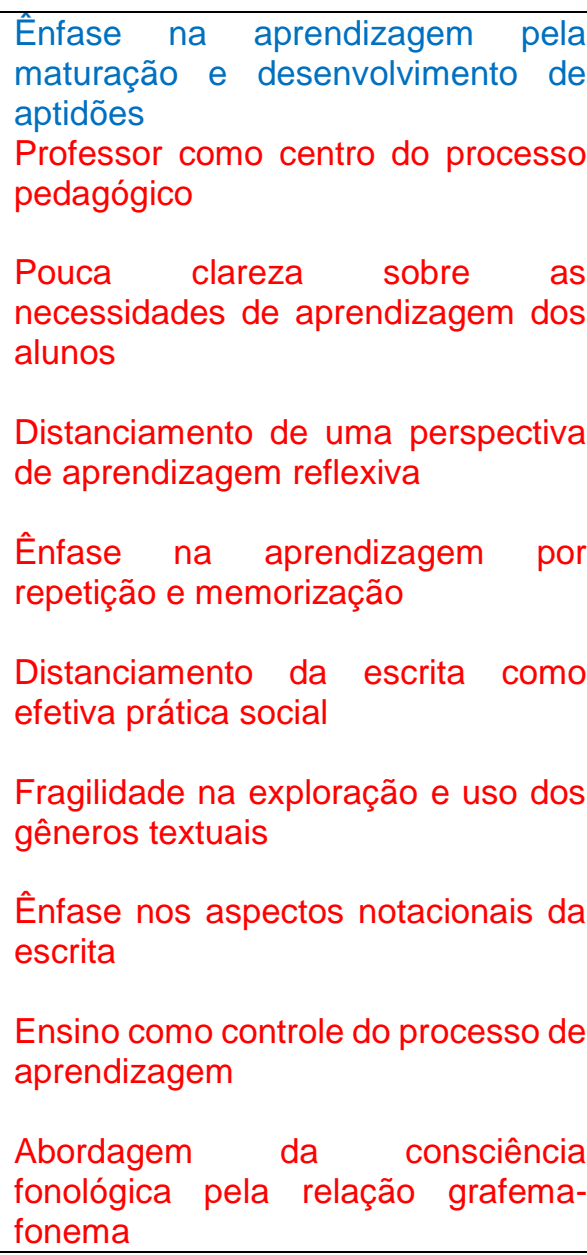 \\
\hline
\end{tabular}

36 Para facilitar a comparação de concepções e posturas, as divergências estão assinaladas. Igualmente, em relação às concepções e práticas de uma e outra professora, foram atribuídas cores a cada uma delas: verde para Bianca, azul para Raquel e vermelho para apontar acepções semelhantes. 


\begin{tabular}{|c|c|c|}
\hline & $\begin{array}{l}\text { Fragilidade na abordagem integrada } \\
\text { dos contextos linguísticos } \\
\text { Incompatibilidade entre as } \\
\text { perspectivas de aprendizagem e a } \\
\text { condução das propostas } \\
\text { Preocupação com o controle da } \\
\text { disciplina visando a promoção da } \\
\text { aprendizagem } \\
\text { Fracasso escolar justificado pelos } \\
\text { aspectos extraescolares } \\
\text { Foco na correção das tarefas }\end{array}$ & 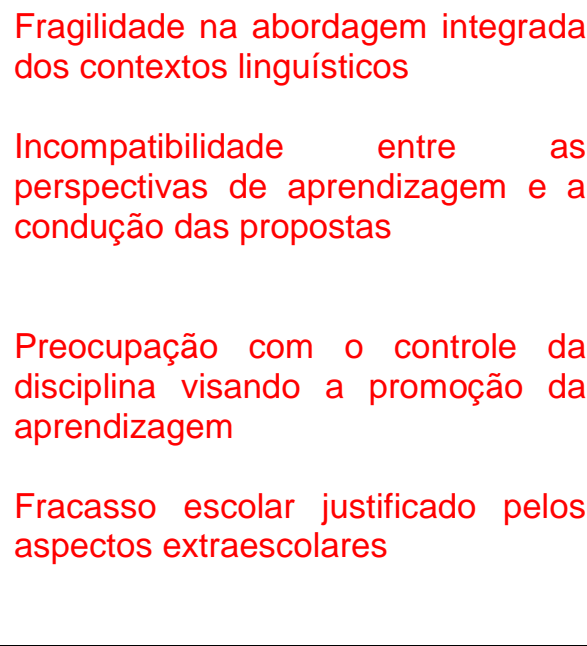 \\
\hline INTERAÇÃO & $\begin{array}{l}\text { Interação como vínculo afetivo } \\
\text { Interação justificada pela competição } \\
\text { Predomínio do trabalho individual } \\
\text { Divisão da turma conforme a } \\
\text { competência dos alunos } \\
\text { Processo interativo nem sempre } \\
\text { pautado em uma relação dialógica } \\
\text { efetiva. }\end{array}$ & $\begin{array}{l}\text { Interação como vínculo afetivo } \\
\text { Interação justificada pela competição } \\
\text { Predomínio do trabalho individual } \\
\text { Divisão da turma conforme a } \\
\text { competência dos alunos } \\
\text { Processo interativo nem sempre } \\
\text { pautado em uma relação dialógica } \\
\text { efetiva. } \\
\text { Interação eficiente apenas fora do } \\
\text { contexto de ensino da língua }\end{array}$ \\
\hline
\end{tabular}

Fonte: elaborado pela pesquisadora.

Como se vê, a investigação constatou a predominância de tendências comuns que, para fins de formação docente e de enfrentamento dos desafios escolares, merecem ser destacados. A pluralidade de posturas remete ao interesse em delinear aspectos mais positivos ou mais negativos, que denotam conquistas, modos de assimilação de princípios e de diretrizes, hesitações, dificuldades e desafios. $\mathrm{Na}$ complexidade das relações entre as concepções (assumidas ou implícitas) e as práticas pedagógicas (mais ou menos consistentes e produtivas) é possível encontrar uma pluralidade de posturas ancoradas em âmbitos mais teóricos ou mais práticos, ou, ainda, na busca de costura entre ambos, como é possível observar no Quadro 26, a seguir ${ }^{37}$ :

${ }^{37}$ As cores deste quadro replicam a organização do quadro anterior (verde - Bianca, azul - Raquel, vermelho - ambas professoras) 
Quadro 26 - Análise comparativa- 1ํ e $2^{\circ}$ anos

\begin{tabular}{|c|c|c|}
\hline Âmbitos & $\begin{array}{l}\text { Ênfases no conceber, } \\
\text { assumir posturas e fazer a } \\
\text { transposição didática }\end{array}$ & Exemplos \\
\hline \multirow{11}{*}{$\begin{array}{lc}\text { Prevalência } & \text { no plano } \\
\text { teórico } & \text { (dimensão } \\
\text { discursiva) } & \end{array}$} & \multirow{4}{*}{$\begin{array}{l}\text { Posturas assumidas pelo } \\
\text { discurso que são mal } \\
\text { assimiladas na prática } \\
\text { pedagógica }\end{array}$} & $\begin{array}{l}\text { - Língua como prática social e meio } \\
\text { de comunicação. }\end{array}$ \\
\hline & & $\begin{array}{l}\text { - Escrita como perpetuação da } \\
\text { memória }\end{array}$ \\
\hline & & $\begin{array}{l}\text { - Natureza dialógica da língua e o } \\
\text { potencial da interação no processo } \\
\text { cognitivo. }\end{array}$ \\
\hline & & $\begin{array}{l}\text { - Escrita como possibilidade de } \\
\text { exercício da cidadania }\end{array}$ \\
\hline & \multirow[t]{2}{*}{$\begin{array}{l}\text { Posturas assumidas pelo } \\
\text { discurso de } \\
\text { reducionista }\end{array}$} & $\begin{array}{l}\text { - Importância da afetividade, mas } \\
\text { limitando o significado afetivo mais } \\
\text { nas relações pessoais do que na } \\
\text { relação com o objeto de } \\
\text { aprendizagem. }\end{array}$ \\
\hline & & $\begin{array}{l}\text { - Importância do trabalho com os } \\
\text { nomes próprios e os termos da } \\
\text { rotina. }\end{array}$ \\
\hline & \multirow[t]{5}{*}{$\begin{array}{l}\text { Posturas contraditórias } \\
\text { assumidas no discurso }\end{array}$} & $\begin{array}{l}\text { - Alfabetização como processo de } \\
\text { construção cognitiva, mas que se } \\
\text { explica pela codificação e } \\
\text { decodificação }\end{array}$ \\
\hline & & $\begin{array}{l}\text { Alfabetização depende da } \\
\text { maturação e do desenvolvimento de } \\
\text { aptidões }\end{array}$ \\
\hline & & $\begin{array}{l}\text { - Diferentes valores (positivo e } \\
\text { negativo) atribuídos a cópia }\end{array}$ \\
\hline & & $\begin{array}{l}\text { - Importância da interação para a } \\
\text { aprendizagem, desde que } \\
\text { fundamentada na competição entre } \\
\text { os alunos. }\end{array}$ \\
\hline & & $\begin{array}{l}\text { - Interação entre professor e alunos } \\
\text { só em possível em contextos que } \\
\text { tratam da vida cotidiana, e não no } \\
\text { ensino da língua. }\end{array}$ \\
\hline \multirow[t]{4}{*}{$\begin{array}{l}\text { Prevalência no plano } \\
\text { prático (dimensão do } \\
\text { fazer pedagógico) }\end{array}$} & \multirow[t]{4}{*}{$\begin{array}{l}\text { Modos de trabalho } \\
\text { tipicamente empirista }\end{array}$} & $\begin{array}{l}\text { - Ênfase no processo de ensino em } \\
\text { detrimento do processo de } \\
\text { aprendizagem dos alunos. }\end{array}$ \\
\hline & & $\begin{array}{l}\text {-Ênfase na aprendizagem por } \\
\text { repetição e memorização, e não pela } \\
\text { reflexão. }\end{array}$ \\
\hline & & centralizadas \\
\hline & & - Predomínio do trabalho individual \\
\hline
\end{tabular}




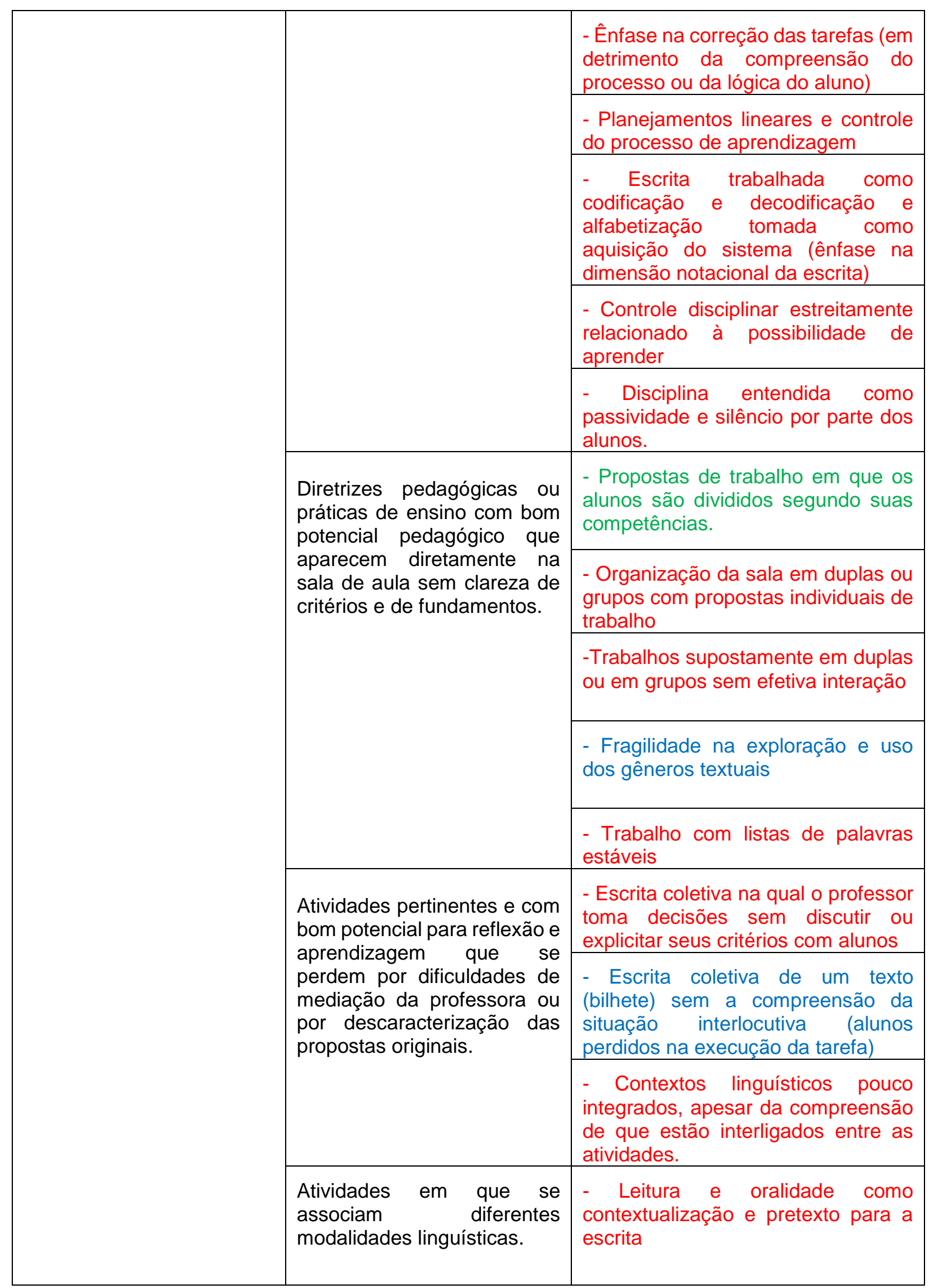




\begin{tabular}{|c|c|c|}
\hline \multirow[t]{9}{*}{$\begin{array}{l}\text { Modos de articulação } \\
\text { entre Teoria e prática }\end{array}$} & \multirow[t]{2}{*}{$\begin{array}{l}\text { Posturas teoricamente } \\
\text { implícitas que se revelam na } \\
\text { prática }\end{array}$} & $\begin{array}{l}\text { - A disciplina é um pré-requisito para } \\
\text { a aprendizagem, razão pela qual } \\
\text { justifica-se o controle disciplinar com } \\
\text { vistas a otimizar o processo de } \\
\text { aprendizagem }\end{array}$ \\
\hline & & $\begin{array}{l}\text { - Diálogo entre professor e aluno } \\
\text { pautado em perguntas indutivas e } \\
\text { respostas que vão ao encontro do } \\
\text { que o aluno entende caminhar em } \\
\text { direção à expectativa docente. }\end{array}$ \\
\hline & \multirow[t]{3}{*}{$\begin{array}{l}\text { Posturas assumidas pelo } \\
\text { discurso coerentes com a } \\
\text { prática }\end{array}$} & $\begin{array}{l}\text { - Escrita como decodificação e } \\
\text { ensino como conhecimento de letras } \\
\text { e sistematização de sílabas }\end{array}$ \\
\hline & & $\begin{array}{l}\text { - Práticas de cópia assumidas como } \\
\text { produtivas "quando o aluno não } \\
\text { consegue escrever por si mesmo" }\end{array}$ \\
\hline & & $\begin{array}{l}\text { Fracasso escolar do aluno } \\
\text { justificado pela pouca participação } \\
\text { da família. }\end{array}$ \\
\hline & \multirow{4}{*}{$\begin{array}{l}\text { Posturas assumidas pelo } \\
\text { discurso em descompasso } \\
\text { com a prática }\end{array}$} & $\begin{array}{l}\text { - Postura discursiva em oposição às } \\
\text { práticas de cópia }\end{array}$ \\
\hline & & $\begin{array}{l}\text { - Ideia de reflexão sobre a língua } \\
\text { como memorização de letras e } \\
\text { sílabas }\end{array}$ \\
\hline & & $\begin{array}{l}\text { - Interação entre os alunos como } \\
\text { promotora de aprendizagem em } \\
\text { contextos nos quais prevalece } 0 \\
\text { trabalho individual }\end{array}$ \\
\hline & & $\begin{array}{l}\text { - Leitura assumida como relevante } \\
\text { no processo de alfabetização em } \\
\text { salas de aula onde não há materiais } \\
\text { de leitura com usos e funções sociais } \\
\text { reais }\end{array}$ \\
\hline
\end{tabular}

Fonte: elaborado pela pesquisadora.

Com base no quadro, o que se observa na efervescência da sala de aula não é a mera aplicação prática de diretrizes teóricas ou metodológicas, mas a turbulência de concepções, posturas, valores, princípios, saberes teóricos e práticos que - mais ou menos assumidos, mais ou menos conscientes, mais ou menos coerentes se digladiam em um jogo do fazer dinâmico, no qual as professoras são desafiadas, ao mesmo tempo em que lançam mão de mecanismos de experimentar ou de resistir, de ousar ou hesitar, de aprender a partir de novos fundamentos ou do estabelecimento de significados únicos em suas próprias salas de aula. 
A partir dessa constatação, vale a pena elencarmos algumas considerações importantes:

\section{A. Posturas assumidas pelo discurso em descompasso com a prática, ou porque são mal assimiladas, ou porque foram assimiladas de modo reducionista}

Observamos, diversas vezes, a existência de concepções acertadas entre as professoras, mas que não se alinham coerentemente às suas práticas junto aos alunos, possivelmente porque tiveram acesso a essas concepções em contextos formativos, como cursos de capacitação e leituras. Em que pese o problema da pouca efetividade na prática do ensino, podemos considerar que a mudança de posturas teoricamente assumidas já representa um ganho por incorporar indícios de revisão do referencial pedagógico.

Nesse contexto, o que mais preocupa é a constatação de posturas contraditórias, que sugerem a confusão das professoras, tendo em vista a valorização de diferentes princípios.

\section{B. Posturas teoricamente implícitas que se revelam na prática}

No âmbito discursivo, as professoras afirmam conduzir o processo de ensino norteando-se em pressupostos construtivistas; no entanto, na maioria das situações, suas práticas se revelam em perspectivas empiristas: aprendizagem por repetição e memorização, atividades centralizadas na professora e a consequente passividade dos alunos; a prioridade do trabalho individual, a valorização da correção das tarefas, o ensino com base na progressão linear dos conteúdos e o controle do processo de aprendizagem; a escrita concebida e trabalhada como codificação e decodificação (alfabetização como aquisição do sistema); prioridade da escrita sobre outras manifestações de linguagem; o controle disciplinar e o silêncio como condições ideais para a aprendizagem

C. Diretrizes pedagógicas ou práticas de ensino com bom potencial pedagógico que aparecem na sala de aula sem clareza de objetivos, de critérios ou de fundamentos

Verificamos que muitas vezes as professoras lançam mão de atividades de impacto (provavelmente vindas do material pedagógico, ou da internet, ou ainda da 
troca de experiências práticas entre professoras). Sob a ótica docente, essas atividades se justificam porque "são bacanas" e "porque as crianças adoram", o que se confunde com o objetivo de aprendizagem estabelecido, a priori, ou em muitos casos, porque não havia clareza de objetivos, critérios e fundamentos para cada proposição de escrita.

D. Atividades pertinentes e com bom potencial para a reflexão e aprendizagem, que são corrompidas no momento da execução

Diversas vezes observamos atividades de escrita que, a princípio, eram potentes desafios cognitivos, mas que, de alguma forma, foram subvertidas nos modos de execução, seja pela má compreensão dos princípios assimilados, seja pela dificuldade de transposição didática

\section{E. Atividades com bom potencial para a aprendizagem em contextos cooperativos, que são deturpadas quando ocorrem em contextos individuais}

Algumas atividades do material didático, originalmente propostas para 0 trabalho reflexivo em grupos, com potencial para debates, reflexões e desafios aos alunos, foram encaminhadas como trabalho individual com a justificativa de economizar, tempo, garantir a correção e atender melhor os alunos pela centralização da tarefa. Dessa forma, ficaram prejudicados oportunidades de intercâmbio, parcerias colaborativas e ampliação do repertório tratado.

\section{F. Práticas idênticas sustentadas por justificativas ou princípios diferentes}

Embora ambas professoras façam uso corrente da cópia nas atividades de escrita, para Raquel, como a aprendizagem depende da maturidade, a cópia é pertinente apenas em contextos de correção, para que o aluno possa fixar a escrita correta; para Bianca, como a aprendizagem depende do desejo de aprender, a cópia se justifica quando o aluno não sabe escrever, razão pela qual precisa de um modelo. 


\section{G. Concepções e práticas coerentes entre si, mas inadequadas em função das concepções curriculares}

$\mathrm{Na}$ comparação entre concepções e práticas de ensino, foi possível observar que, em certos momentos, a sintonia entre elas não necessariamente está de acordo com os princípios do currículo. Em outras palavras, a coerência na perspectiva da professora contraria a coerência prevista pelas diretrizes de ensino. Um exemplo disso fica notório no caso de conceber a alfabetização como aquisição do sistema e ensinar de modo mecânico, aspectos que não estão previstos pelo Currículo da Cidade e tampouco pelos referenciais teóricos discutidos nas JEIFs, conforme descrito pela Coordenação Pedagógica, que organiza e orienta esses momentos.

\section{H. Aspectos incoerentes entre si, independentemente das concepções curriculares}

Do mesmo modo, diferentes aspectos docentes mostraram-se incoerentes entre si, como as professoras definirem a escrita como um modo de comunicação e ensiná-la de forma mecânica. Isso contraria, em princípio, a concepção dialógica da língua, que quando assim compreendida, prevê uma aprendizagem pautada em experiências linguísticas capazes de ampliar as possibilidades de comunicação e de expressão, e não as reduzir pelo ensino mecanicista e orientado pela repetição e memória.

Compreender que os alunos aprendem mecanicamente contraria ainda o pressuposto de relevância atribuída às interações sociais nos processos de aprendizagem. Na prática, isso ficou evidente quando os alunos foram desencorajados a se comunicar durante as atividades, situações em que poderiam vivenciar a língua em diversos contextos e com diferentes funções.

\section{Frágil articulação entre as modalidades linguísticas}

Observamos, diversas vezes, que na intenção de articular diferentes modalidades da língua, as professoras propuseram atividades de escrita a partir de uma leitura feita previa e individualmente pelos alunos ou coletivamente. Sem que houvesse um efetivo apoio para a escrita, o texto funcionava como pretexto. É possível que esse encaminhamento parecesse adequado às professoras pela sequenciação das propostas, ou por pertencerem a um mesmo universo temático; no entanto, a dissociação entre elas era visível. 
O conjunto das considerações acima permite confirmar a hipótese original do estudo de que as práticas de ensino e as dinâmicas interativas propostas em aula são tributárias de concepções docentes. No entanto, essa relação, longe de ser previsível e direta no processo de transposição didática, se concretiza de modo complexo e turbulento, ora pontuado por coerências, ora marcado por conflitos internos entre o dizer e o fazer, ou ainda por contradições com os princípios assumidos pelo currículo e com as contribuições teóricas, mais ou menos recentes, das ciências.

$\mathrm{Na}$ perspectiva individual de cada professora, essa turbulência sugere, paralelemente aos acertos, dificuldades, dúvidas e hesitações que afetam a condução eficiente do ensino.

Na perspectiva mais geral, a desejável construção de uma progressão coerente nos sucessivos anos parece igualmente afetada, já que, no âmbito da mesma escola, não se pode garantir a valorização das mesmas ênfases e dos mesmos princípios, ou a continuidade dos processos de ensino e os modos de intervenção. Assim, para o aluno que segue do primeiro para o segundo ano, é possível que ele se veja estimulado por diferentes lógicas e com diferentes ênfases, nem sempre compatíveis com o projeto político-pedagógico da instituição ou dos programas municipais prescritos.

Embora esses fatores, por si só, não sejam suficientes para explicar o cenário do fracasso escolar e os resultados negativos das avaliações de desempenho dos estudantes, não seria um exagero dizer que eles fazem parte de um complexo de fatores que desafiam políticos, educadores e especialistas na superação dos problemas educacionais. Ao lado de outros fatores como as injustiças sociais, a má distribuição dos bens culturais, a distribuição e uso de verbas públicas, a busca pela qualidade da educação passa necessariamente pelo trabalho desenvolvido pelos professores em sala de aula e do apoio que eles precisam para desenvolver seu trabalho. Por isso, não se trata de culpabilizá-los pelo mal desempenho dos alunos, mas de compreender a tortuosidade dos caminhos que comprometem a construção do ensino.

Nesse sentido, vale levantar algumas hipóteses explicativas que talvez ajudem a compreender melhor as dificuldades dos professores em modificar as próprias concepções e práticas: 
- Dificuldade de lidar com uma cultura escolar muito arraigada, em que predomina o modelo empirista de ensino, difícil de superar.

- Em muitos casos, prevalece a lógica do "ensinar tal como aprendi a ler e escrever", contrariando as contribuições dos estudos psicogenéticos e linguísticos.

- Ineficiência, superficialidade ou fragmentação do processo formativo, tanto na formação inicial, quanto em serviço.

- Contribuições teóricas sobre língua e a aprendizagem mal difundidas ou mal assimiladas.

- Processos formativos centrados no âmbito teórico: a professora compreende a ideia, o pressuposto, mas não sabe como transpor o referencial (supostamente) assimilado para a pedagógica. Há casos também em que a professora consegue perceber inadequações no modo de conduzir o trabalho, mas não consegue se corrigir no contexto ou no curso da tarefa.

- Atividades do material didático com bom potencial pedagógico que, pelos mesmos motivos acima mencionados, são corrompidas pela dificuldade de mediação da professora.

- Apropriação de uma prática ou diretriz por si mesma (a professora que toma conhecimento de que uma atividade interessante, executando-a sem ter clareza de seu potencial pedagógico)

- Prevalência de concepções tradicionais bastante arraigadas na cultura escolar, como a ideia de que as crianças aprendem mais quando estão sozinhas, quietas ou em interação direta com o professor.

- Compreensão mecanicista sobre a consciência fonológica (não como reflexão sobre o sistema, mas como associação de letras e sons).

- As práticas podem ser condicionadas por mecanismos de avaliação como as sondagens que levam em conta apenas as hipóteses de escrita (conflito difuso entre princípios ou recomendações curriculares e os critérios objetivos de avaliação).

No início deste estudo, o problema que se impunha e nos orientava nos objetivos de pesquisa implicava em entender a relação entre os avanços teóricos, as concepções docentes sobre o ensino da língua escrita e as práticas de ensino. 
Chegamos ao fim deste trabalho tendo elaborado algumas conclusões, mas entendendo que estas nos levam a novas dúvidas, geram novas conjecturas e remetem a novas inquietações, que apontam para novos caminhos de investigação.

Como implicação mais direta deste estudo, fica o desafio de se investir na formação docente e no acompanhamento dos trabalhos desenvolvidos nas escolas em um constante processo de fazer e refazer, compreender e intervir, construir e reconstruir, refletir e praticar e, sobretudo, de valorizar a profissão docente. 


\section{REFERÊNCIAS ${ }^{38}$}

ABREU, Ana Rosa et al. Alfabetização: livro do professor. Brasília: FUNDESCOLA/SEF-MEC, 2000.

ANA. Avaliação Nacional da Alfabetização. Documento Básico. 2013. Disponível em: download.inep.gov.br/educacao_basica/saeb/2013/ivreto_ANA_online.pdf. Acesso em: 08 jul. 2018.

ARANHA, Maria Salete Fábio. A interação social e o desenvolvimento humano. Temas psicol., Ribeirão Preto, v. 1, n. 3, p. 19-28, dez. 1993. Disponível em: http://pepsic.bvsalud.org/scielo.php?script=sci_arttext\&pid=S1413389X1993000300004\&lng=pt\&nrm=iso. Acesso em: 25 fev. 2019.

BAGNO, Marcos. Linguística da norma. São Paulo: Loyola, 2002.

BAKHTIN, Mikhail (VOLOSHINOV, N.) Marxismo e filosofia da linguagem. São Paulo: Hucitec, 1988.

BARDIN, Laurence. Análise de conteúdo. Portugal: Edições 70, 1977.

BECKER, Fernando. Educação e construção do conhecimento. Porto Alegre: Penso, 2012.

BERNARDES, Maria Eliza; ASBAHR, Flávia Ferreira da Silva. Atividade pedagógica e 0 desenvolvimento das funções psicológicas superiores. Perspectiva, Florianópolis, v. 25, n. 2, p. 315-342, jul./dez. 2007. Disponível em: http://www.perspectiva.ufsc.br. Acesso em: 25 jul. 2018.

BORTOLOTTO, Nelita. A interlocução na sala de aula. São Paulo: Martins Fontes, 1998.

BRASIL. PCN - Parâmetros Curriculares Nacionais. Língua Portuguesa. Secretaria de Educação Fundamental. Brasília, 1997.

BRASIL. BCCN - Base Nacional Comum Curricular. Ministério da Educação, Secretaria de Educação Básica, 2017. Disponível em: http://basenacionalcomum.mec.gov.br. Acesso em: 09 jul. 2018.

CAMPOS JÚNIOR, Lázaro. Aumento da escolaridade tem efeito positivo, mas analfabetismo funcional ainda é alto no Brasil. 12 nov. 2018. Todos pela Educação. Disponível em: https://www.todospelaeducacao.org.br/conteudo/inaf-3-em-cada-10brasileiros-nao-conseguiriam-entender-este-texto. Acesso em: 12 jan. 2020.

CASTANHO, Irene Siqueira. Sobre o sujeito que aprende. In: BARONE, Leda Maria Codeço; MARTINS, Lilian Cassia Bacich; CASTANHO, Irene Siqueira.

${ }^{38}$ De acordo com a Associação Brasileira de Normas Técnicas NBR 6023. 
Psicopedagogia: Teorias da Aprendizagem. São Paulo: Casa do Psicólogo, 2011. p. 15-35.

CASTORINA, José Antonio et al. Piaget e Vygotski. São Paulo: Ática, 2006.

CAVALCANTE, Marianne Carvalho Bezerra. Situação Comunicativa. Glossário CEALE. UFMG, 2020. Disponível em: http://www.ceale.fae.ufmg.br/app/webroot/glossarioceale/verbetes/situacaocomunicativa. Acesso em: 23 jan. 2020.

COELHO, Lígia Martha. Língua materna nas séries iniciais do Ensino Fundamental: de concepções e de suas práticas. Petrópolis: Vozes, 2009.

COLELLO, Silvia Mattos Gasparian. Alfabetização em questão. Rio de Janeiro: Paz e Terra, 2004.

A escola que (não) ensina a escrever. São Paulo: Paz e Terra, 2007.

Alfabetização e letramento. São Paulo: Summus, 2010.

Modelos de Ensino: das concepções docentes às práticas pedagógicas. Eaulas USP: Aula ministrada no Curso "Ética, valores e Saúde, da UNIVESP Universidade Virtual do Estado de São Paulo, 2011. Disponível em: https://www.silviacolello.com.br/projects. Acesso em: 03 ago. 2018.

Modelos de Ensino: das concepções docentes às práticas pedagógicas. Eaulas USP: Aula ministrada no Curso "Ética, valores e cidadania", da UNIVESP Universidade Virtual do Estado de São Paulo, 2012. Disponível em: https://www.silviacolello.com.br/projects. Acesso em: 03 ago. 2018.

A escola e as condições de produção textual: conteúdos, formas e relações. 2015. 495 f. Tese (Livre Docência) - Faculdade de Educação, Universidade de São Paulo. São Paulo, 2015.

A escola e a produção textual: práticas interativas e tecnológicas. São Paulo: Summus, 2017.

COLELLO, Silvia de Mattos Gasparian; LUIZE, Andréa. Aventura linguística. Viver Mente \& Cérebro, Coleção Memória da Pedagogia, São Paulo, n. 5, p. 68-73, 2006.

COLL, César. Linguagem, atividade e discurso na sala de aula In: COLL, César, PALACIOS, Jesús; MARCHESI, Álvaro (Orgs.). Desenvolvimento psicológico e educação: Psicologia da Educação, V. 2. Porto Alegre: Artes Médicas, 2004. p. 261279.

COLL, César; SOLÉ, Isabel. Ensinar e aprender no contexto da sala de aula. In: COLL, César, PALACIOS, Jesús; MARCHESI, Álvaro (Org.). Desenvolvimento psicológico e educação: Psicologia da Educação, V. 2. Porto Alegre: Artes Médicas, 2004. p. 241-260. 
CORTELLA, Mario Sergio. Educação, convivência e ética: audácia e esperança. São Paulo: Cortez, 2015.

CUNHA, Marcus Vinícius. Piaget: Psicologia Genética e Educação. Rio de Janeiro: Editora Lampari, 2008.

DAVIS, Cláudia; SILVA, Maria Alice Setúbal; ESPÓSITO, Yara. Papel e valor das interações sociais em sala de aula. Cadernos de Pesquisa, São Paulo, n. 71, p. 4954, nov. 1989. 1 Disponível em: http://publicacoes.fcc.org.br/ojs/index.php/cp/article/view/1168/1173. Acesso em: 05 fev. 2019.

DAVIS, Cláudia; OLIVEIRA, Zilma de. Psicologia na Educação. São Paulo: Cortez, 2010.

FARACO, Carlos Alberto. Linguagem e Diálogo, as ideias linguísticas do Círculo de Bakhtin. São Paulo: Parábola Editorial, 2009.

FERREIRO, Emília. Psicogênese da Língua Escrita. Porto Alegre: Artes Médicas, 1986.

Reflexões sobre Alfabetização. São Paulo: Cortez,1989.

Atualidade de Jean Piaget. Porto Alegre: Artmed, 2001a.

Cultura escrita e educação. Porto Alegre: Artmed, 2001b.

Passado e presente dos verbos ler e escrever. São Paulo: Cortez, 2002.

O ingresso na escrita e nas culturas do escrito: seleção de textos de pesquisa. São Paulo: Cortez, 2013.

FERREIRO, Emília; TEBEROSKY, Ana. Psicogênese da língua escrita. Porto Alegre, Artmed, 1999.

FIORIN, José Luiz. Língua, discurso e política. Alea, Rio de Janeiro, v. 11, n. 1, p. 148-165, jun. 2009. Disponível em: http://www.scielo.br/scielo.php?script=sci_arttext\&pid=S1517-

106X2009000100012\&lng=en\&nrm=iso. Acesso em: 14 fev. 2020.

FORMOSINHO, Julia Oliveira; KISHIMOTO, Tizuko Morchida; PINAZZA, Monica Apezzatto (Orgs.). Pedagogia(s) da infância: dialogando com o passado, construindo o futuro. Porto Alegre: Artmed, 2007.

FREIRE, Paulo. A importância do ato de ler. São Paulo: Autores Associados/Cortez, 1983.

FREITAG, Barbara Rouanet. Razão teórica e razão prática: Kant e Piaget. Ande Revista da Associação Nacional de Educação, São Paulo, v. 15, p. 55-68, 1990. 
FREITAS, Maria Tereza de Assunção. Vygotsky e Bakhtin - Psicologia e Educação: um intertexto. São Paulo: Ática, 2002.

GAGE, Nathaniel Lees. Handbook of research on teaching. Rand McNally: Chicago, 1963.

GARCíA, Xus Martín; PUIG, Josep Maria. As sete competências básicas para educar em valores. São Paulo: Summus, 2010.

GERALDI, João Wanderley. Portos de Passagem. São Paulo: Martins Fontes, 1997.

GIUSTA, Agnela da Silva. Concepções de aprendizagem e práticas pedagógicas. Educação em Revista, Belo Horizonte, v. 29, n. 1, p. 17-36, mar. 2013. Disponível em http://www.scielo.br/pdf/edur/v29n1/a03v29n1.pdf. Acesso em: 02 jun. 2018.

GOOGLE MAPS. 2019. Disponível em: https://www.google.com.br/maps/place/Jaguar\%C3\%A9,+S\%C3\%A30+Paulo+-+SP. Acesso em: 10 jul. 2019.

GOUVEIA, Denise da Cruz. A epistemologia genética de Piaget e a psicopedagogia. In: BARONE, Leda Maria Codeço; MARTINS, Lilian Cassia Bacich; CASTANHO, Irene Siqueira. Psicopedagogia: Teorias da Aprendizagem. São Paulo: Casa do Psicólogo, 2011. p. 119-160.

HERMANN, Nadja. Ética \& Educação: outra sensibilidade. Belo Horizonte: Autêntica, 2014.

HOUAISS, Antonio. Dicionário Houaiss da Língua Portuguesa. Versão Online. 2020. Disponível em: https://houaiss.uol.com.br/pub/apps/www/v33/html/index.php\#2. Acesso em: 21 fev. 2020.

IDEB. EMEF Marechal Espiridião Rosas. 2017. Disponível em: http://idebescola.inep.gov.br/ideb/escola/dadosEscola/35053247. Acesso em: 20 set. 2019.

IDEB. EMEF Marechal Espiridião Rosas. 2005-2017. Disponível em: http://idebescola.inep.gov.br/ideb/escola/dadosEscola/35053247. Acesso em: 20 set. 2019.

INAF. Indicador de Alfabetismo Funcional. INAF Brasil 2018: resultados preliminares. São Paulo: Ação Educativa; Instituto Paulo Montenegro, 2018. Disponível em: http://acaoeducativa.org.br/wpcontent/uploads/2018/08/Inaf2018_Relat\%C3\%B3rio-Resultados-

Preliminares_v08Ago2018.pdf. Acesso em: 10 jul. 2018.

INAF. Índice Nacional de Alfabetismo Funcional. Letramento e mundo do trabalho. São Paulo: Ação Educativa; 2016. Disponível em: 
http://acaoeducativa.org.br/wpcontent/uploads/2016/09/INAFEstudosEspeciais_201 6_Letramento_e_Mundo_do_Trabalho.pdf. Acesso em: 18 maio 2018.

INEP. Desempenho da sua escola. Prova Brasil 2015. EMEF Mal. Espiridião Rosas. Acesso restrito. Disponível em: sistemasprovabrasil.inep.gov.br/provaBrasilResultados/view/boletimDesempenho/b oletimDesempenho.seam. Acesso em: 10 set. 2019.

INEP. Desempenho da sua escola. Prova Brasil 2017. EMEF Mal. Espiridião Rosas. Acesso restrito. Disponível em: sistemasprovabrasil.inep.gov.br/provaBrasilResultados/view/boletimDesempenho/b oletimDesempenho.seam. Acesso em: 12 set. 2019.

INEP. Escala de Proficiência de Língua Portuguesa 5o Ano do Ensino Fundamental. $2015 . \quad$ Disponível em: http://download.inep.gov.br/educacao_basica/prova_brasil_saeb/escala/escala_profi ciencia/2018/LP_5EF.pdf. Acesso em:

INEP. Censo Escolar 2016. Brasília: 2017. Disponível em: http://portal.mec.gov.br/docman/fevereiro-2017-pdf/59931-app-censo-escolar-daeducacao-basica-2016-pdf-1/file. Acesso em: 24 jul. 2018.

INEP. Relatório do $1^{\circ}$ Ciclo de Monitoramento das metas do PNE-Biênio 20142016. Brasília: INEP, 2016. Disponível em: http://download.inep.gov.br/outras_acoes/estudos_pne/2016/relatorio_pne_2014_a_ 2016.pdf\#page=1\&zoom=auto,-89,786. Acesso em: 12 dez. 2018.

INEP. Relatório do 2 - Ciclo de Monitoramento das Metas do Plano Nacional de Educação - 2018. Brasília: INEP, 2018. Disponível em: http://portal.inep.gov.br/informacao-da-publicacao//asset_publisher/6JYIsGMAMkW1/document/id/6725829. Acesso em: 12 dez. 2018.

IPM. Metodologia. 2016. Disponível em: https://ipm.org.br/inaf. Acesso em: 18 set. 2018.

IPM. Indicador de Alfabetismo Funcional - INAF Brasil 2018: resultados preliminares. São Paulo: Ação Educativa; Instituto Paulo Montenegro, 2018. Disponível em: http://acaoeducativa.org.br/wpcontent/uploads/2018/08/Inaf2018_Relat\%C3\%B3rio-ResultadosPreliminares_v08Ago2018.pdf. Acesso em: 10 jul. 2018.

KATO, Mary. No mundo da escrita. São Paulo: Ática, 1986.

KLEIMAN, Angela B. Os significados do letramento: uma nova perspectiva sobre a prática social da escrita. Campinas: Mercado das Letras, 1995.

LA TAILLE, Yves; OLIVEIRA, Marta Kohl; DANTAS, Heloysa. Piaget, Vygotsky, Wallon: Teorias Psicogenéticas em Discussão. São Paulo: Summus, 1992. 
LERNER, Delia. Ler e escrever na escola: o real, o possível e o necessário. Porto Alegre: Artmed, 2002.

É preciso dar sentido à leitura. Nova Escola. São Paulo: Abril, 2006.

LUDKE, Menga; ANDRÉ, Marli. Pesquisa em Educação: abordagens qualitativas. São Paulo: EPU/EDUSP, 1986.

MACEDO, Lino de. A questão da inteligência: todos podem aprender? In: OLIVEIRA, Marta Kohl; SOUZA, Denise Trento. REGO, Teresa Cristina (Orgs.). Psicologia, educação e as temáticas da vida contemporânea. São Paulo: Moderna, 2002. p. 117-134.

MACEDO, Maria do Socorro. Interações na prática do letramento: o uso do livro didático e da metodologia de projetos. São Paulo: Martins Fontes, 2005.

MARCUSCHI, Luiz Antônio. Produção textual, análise de gêneros e compreensão. São Paulo: Parábola Editorial, 2008.

Da fala para a escrita: atividades de retextualização. São Paulo: Cortez, 2010.

MATUI, Jiron. Construtivismo: teoria construtivista sócio-histórica aplicada ao ensino. São Paulo: Moderna, 1995.

MAURI, Teresa. O que faz com que o aluno e a aluna aprendam os conteúdos escolares?. In: COLL, César et al. O construtivismo na sala de aula. São Paulo: Ática, 2006, p. 79-122.

MEC. Ministério da Educação. MEC anuncia Política Nacional de Alfabetização para reverter estagnação na aprendizagem. 2017. Disponível em: http://portal.mec.gov.br/ultimas-noticias/211-218175739/56321-mec-anuncia-politicanacional-de-alfabetizacao-para-reverter-estagnacao-na-aprendizagem. Acesso em: 20 ago. 2018.

MEC. Ministério da Educação. Manual operacional do sistema de orientação pedagógica e monitoramento. Programa Mais Alfabetização. 2018. Disponível em: http://portal.mec.gov.br/index.php?option=com_docman\&view=download\&alias=864 71-manual-operacional-2-pmalfa-20-04-2018\&category_slug=abril-2018pdf\&ltemid=30192. Acesso em: 11 ago. 2018.

MENDONÇA, Onaide Schwartz. Equívocos e consequências em sala de aula: les idées fausses et les conséquences dans la salle de classe. Acoalfa - Acolhendo a Alfabetização nos Países de Língua Portuguesa, São Paulo, v. 6, n. 11, p. 28-48, fev. 2012. Disponível em: http://www.revistas.usp.br/reaa/article/view/11590/13358. Acesso em: 01 jun. 2018.

MICOTTI, Maria Cecília de Oliveira. Alfabetização, propostas e práticas pedagógicas. São Paulo: Contexto, 2013. 
MIRANDA, Maria Irene. Epistemologia genética, alfabetização e letramento. Educ. e Filos., Uberlândia, v. 22, n. 44, p. 141-158, jul./dez. 2008.

MIZUKAMI, Maria da Graça Nicoletti. Ensino, as abordagens do processo. São Paulo: EPU, 2013.

MOLINARI, Cláudia. Situações de escrita para saber mais sobre um tema em momentos de alfabetização inicial. In: $\mathbf{3 0}$ Olhares para o futuro. Publicação da Escola da Vila. São Paulo: Centro de Formação, 2010. p. 119-125.

MORTATTI, Maria do Rosário Longo. Educação e Letramento. São Paulo: UNESP, 2004.

Produção acadêmica brasileira sobre alfabetização: avaliação da qualidade e impacto científico e social. In: MORTATTI, Maria do Rosário Longo; FRADE, Isabel Cristina Alves da Silva. (Orgs.). Alfabetização e seus sentidos: o que sabemos, fazemos e queremos? Marília: Oficina Universitária; São Paulo: Editora Unesp, 2014. p. 131-158.

NOGUEIRA, Maria Alice; NOGUEIRA, Claudio Martins. Bourdieu \& a educação. Belo Horizonte: Autêntica Editora, 2017.

NOT, Louis. Ensinando a aprender: elementos de Psicodidática geral. São Paulo: Summus, 1993.

NÓVOA, Antonio (Org.). Profissão Professor. Portugal: Porto Editora, 1999.

Universidade e formação docente. Interface, Botucatu, v. 4, n. 7, p. 129138, ago. 2000.2 Disponível em: http://www.scielo.br/scielo.php?script=sci_arttext\&pid=S1414$32832000000200013 \& \operatorname{lng}=e n \& n r m=i s o$. Acesso em: 05 fev. 2018.

OLIVEIRA, Marta Kohl de. Vygotsky, aprendizado e desenvolvimento: um processo sócio histórico. Coleção Pensamento e ação no magistério. São Paulo: Scipione, 1997.

Lev Vygotsky: mídia e educação. Coleção Grandes Educadores. Vídeo aula. São Paulo: Paulus, 2006.

OLIVEIRA, Romualdo. Da universalização do ensino fundamental ao desafio da qualidade: uma análise histórica. Educação \& Sociedade, Campinas, v. 28, n. 100, p. 661-690, out. 2007.

OLSON, David R. El mundo sobre el papel: el impacto de la escritura en la estructura del conocimiento. Colección L.E.A. Barcelona: Gedisa Editorial, 1998. 
OPNE. Observatório do PNE. 2018. Disponível em: http://www.observatoriodopne.org.br/uploads/reference/file/439/documentoreferencia.pdf. Acesso em: 14 jun. 2019.

ORLANDI, Eni Puccineli. O que é linguística. São Paulo: Brasiliense, 2009.

PALANGANA, Isilda Campaner. Desenvolvimento e aprendizagem em Piaget e Vigotsky: a relevância do social. São Paulo: Summus, 2015.

PENIN, S. "Profissão docente e contemporaneidade" In ARANTES (org.) Profissão docente: pontos e contrapontos. São Paulo: Summus, 2009, p. 16-40

PERRENOUD, Philippe. Dez novas competências para ensinar. Porto Alegre: Artes Médicas Sul, 2000.

As competências para ensinar no século XXI: a formação dos professores e o desafio da avaliação. Porto Alegre: Artmed, 2002.

Desenvolver competências ou ensinar saberes: a escola que prepara para a vida. Porto Alegre: Penso, 2013

PIAGET, Jean. A construção do real na criança. Rio de Janeiro: Zahar Editores, 1963.

Seis estudos de Psicologia. Tradução Maria Alice M. D'Amorim e Paulo Sérgio L. Silva. Rio de Janeiro: Forense Universitária, 1999.

PNAIC. Pacto Nacional pela Alfabetização na Idade Certa. 2012. Disponível em: http://www.abmes.org.br/abmes/public/arquivos/legislacoes/Port-867-2012-0704.pdf. Acesso em: 13 abr. 2018.

PONTECORVO, Clotilde; AJELLO, Anna Maria; ZUCCERMAGLIO, Cristina. Discutindo se aprende: interação social, conhecimento e escola. Porto Alegre: Artmed, 2005.

PPP. Projeto Político Pedagógico. Escola Municipal de Ensino Fundamental Espiridião Rosas. 2019. São Paulo.

REIS, Thaíze de Souza. Avaliação da eficácia de um programa suplementar para o ensino de leitura e escrita aplicado em ambiente escolar. 2009. 137f. Dissertação (Mestrado em Educação Especial) - Programa de Pós-Graduação em Educação Especial, Universidade Federal de São Carlos, São Carlos, 2009.

REIS, Elisabete Rodrigues dos. Lugar do sentido. Revista NUFEN, Belém, v. 9, n. 2, p. 109-123, 2017. Disponível em: http://pepsic.bvsalud.org/scielo.php?script=sci_arttext\&pid=S2175-

25912017000200008\&lng=pt\&nrm=iso. Acesso em: 20 fev. 2020. 
RENFREW, Alastair. Mikhail Bakhtin. Tradução Marcos Marcionilo. 1. ed. São Paulo: Parábola, 2017.

SAEB/ANA. Relatório SAEB/ANA 2016: panorama do Brasil e dos estados. Brasília: Instituto Nacional de Estudos e Pesquisas Educacionais Anísio Teixeira, 2018.

SANTOMAURO, Beatriz. Inatismo, empirismo e construtivismo: três ideias sobre a aprendizagem. Nova Escola. 05 nov. 2010. Disponível em: https://novaescola.org.br/conteudo/41/inatismo-empirismo-e-construtivismo-tresideias-sobre-a-aprendizagem. Acesso em: 01 jun. 2018.

SÃO PAULO. (Cidade). Currículo de língua portuguesa para a cidade de São Paulo. 2017. Disponível em: http://patiodigital.prefeitura.sp.gov.br/wpcontent/uploads/sites/4/2017/05/Leitura-pr\%C3\%A9via_curr\%C3\%ADculoLP_1\%C2\%BA-encontro.pdf. Acesso em: 19 jul. 2019.

SÃO PAULO. (Cidade). Currículo da Cidade São Paulo: orientações didáticas de Língua Portuguesa. São Paulo: Secretaria Municipal de Educação (SME)/ Coordenadoria Pedagógica (COPED), 2018. Disponível em: https://educacao.sme.prefeitura.sp.gov.br/wp-content/uploads/2019/07/45152.pdf.

Acesso em: 11 jul. 2018.

SAVIANI, Dermeval. As concepções pedagógicas na história da educação brasileira. Texto elaborado no âmbito do projeto de pesquisa "O espaço acadêmico da pedagogia no Brasil", financiado pelo CNPq, para o projeto, v. 20. 2005.

SEVERINO, Antônio Joaquim. Metodologia do trabalho científico. São Paulo: Cortez, 2007.

SMOLKA, Ana Luiza Bustamante; NOGUEIRA, Ana Lúcia Horta. O desenvolvimento cultural da criança: mediação, dialogia e inter(regulação). In: OLIVEIRA, Marta Kohl de; SOUZA, Denise Trento Rebello de; REGO, Teresa Cristina (Orgs.). Psicologia, educação e temáticas da vida contemporânea moderna: São Paulo, 2002. p. 7794.

SOARES, Magda. Língua escrita, sociedade e cultura: relações, dimensões e perspectivas. Revista Brasileira de Educação, Belo Horizonte, n. 0, p. 5-16, set./out./nov./dez., 1995.

Letramento, um tema em três gêneros. Belo Horizonte: Autêntica, 1998.

Alfabetização e letramento. São Paulo: Contexto, 2008.

2012.

Letramento, um tema em três gêneros. Belo Horizonte: Autêntica Editora,

Linguagem e escola: uma perspectiva social. São Paulo: Contexto, 2017. 
STREET, Brian. Letramentos sociais: abordagens críticas do letramento no desenvolvimento, na etnografia e na educação. São Paulo: Parábola Editorial, 2014.

TEBEROSKY, Ana; TOLCHINSKY, Liliana. Além da Alfabetização. São Paulo: Ática, 1997.

TEIXEIRA, Teresa Cristina Fernandes. A perspectiva infantil sobre a escrita na escola. In: COLELLO, Silvia Mattos Gasparian. Textos em contextos: reflexões sobre o ensino da língua escrita. São Paulo: Summus, 2011. p. 77-100.

TESSER, Gelson João. Principais linhas epistemológicas contemporâneas. Educar, Curitiba, n. 10, p. 91-98, dez. 1995. Disponível em: http://www.scielo.br/pdf/er/n10/n10a12.pdf. Acesso em: 11 jul. 2018.

TFOUNI, Leda Verdiani. Letramento e alfabetização. São Paulo: Cortez, 2010.

TOGNETTA, Luciene Regina Paulino. A dinâmica de um ambiente cooperativo. Anais. XVIII Encontro Nacional de Professores do PROEPRE: "Transformar a educação: Nosso Desafio". Campinas, Faculdade de Educação, Unicamp, 2001. p. 165-173.

TUAN, Yi-Fu. Espaço e Lugar: a perspectiva da experiência. São Paulo: DIFEL, 1983.

UNESCO. Relatório "Educação, um tesouro a descobrir". 2010. Disponível em: http://unesdoc.unesco.org/images/0010/001095/109590por.pdf. Acesso em: 05 maio 2018.

UNESCO. Relatório de monitoramento global da educação 2017/2018. Cumprir nossos compromissos, responsabilização na educação. Resumo. 2017. Disponível em: http://unesdoc.unesco.org/images/0025/002595/259593por.pdf. Acesso em: 13 jan. 2018.

VARANDA, Gabriela; MAGRI, leda. Registro da Memória. Revista "A Palavra". São Paulo, SESC, $2011 . \quad$ Disponível em: http://www.sesc.com.br/wps/wcm/connect/sesc/site/palavra/ensaio/ensaios_interna/r egistro+da+memoria . Acesso em: 25 jan. 2020.

VIGOTSKI, Lev Semenovitch. A formação social da mente: o desenvolvimento dos processos psicológicos superiores. São Paulo: Martins Fontes, 2007.

Pensamento e linguagem. São Paulo: Martins Fontes, 2008.

VINHA, Telma Pileggi; TOGNETTA, Luciene Regina Paulino. Construindo a autonomia moral na escola: os conflitos interpessoais e a aprendizagem dos valores. Revista Diálogo Educ., Curitiba, v. 9, n. 28, p. 525-540, set./dez. 2009.

VOLÓCHINOV, Valentin. Marxismo e filosofia da linguagem: problemas fundamentais do método sociológico na ciência da linguagem. São Paulo: Editora 34, 2017. 
ZABALA, Antoni. A prática educativa: como ensinar. Porto Alegre: Artmed, 1998. Como aprender e ensinar competências. Porto Alegre: Artmed, 2010.

WEISZ, Telma; SANCHEZ, Ana. O diálogo entre o ensino e a aprendizagem. São Paulo: Ática, 1985.

WEISZ, Telma; SANCHEZ, Ana. O diálogo entre o ensino e a aprendizagem. São Paulo: Ática, 1999.

O diálogo entre o ensino e a aprendizagem. São Paulo: Ática, 2002. 


\section{APÊNDICE}

\section{TERMO DE CONSENTIMENTO LIVRE E ESCLARECIDO}

\section{Pesquisa: Práticas de escrita em contextos de alfabetização: caminhos e descaminhos}

Prezado(a) Professor(a),

Esta pesquisa trata das práticas de escrita desenvolvidas no contexto escolar durante o processo de alfabetização e está sendo desenvolvida por mim, Andrea Beatriz Gonzalez Frigo, da Faculdade de Educação da Universidade São Paulo, sob a orientação da Profa. Dra. Silvia Maria Gasparian Colello.

Buscando compreender as relações que se estabelecem entre a teoria e a prática docente, trata-se de um estudo que tem como objetivos conhecer as concepções dos professores de Ensino Fundamental sobre a escrita e seu ensino, bem como a respeito das intervenções docentes e o papel das interações ao longo do processo de alfabetização.

Para tanto, solicito sua autorização para fazer observações em aula e sua colaboração em uma breve entrevista. As situações previstas nesta investigação não representam quaisquer prejuízos pessoais ou morais aos professores e alunos.

Sua participação é voluntária e, portanto, você não é obrigado(a) a fornecer as informações e/ou colaborar com as atividades solicitadas pela pesquisadora. Caso decida não participar do estudo ou resolver, a qualquer momento, desistir do mesmo, não sofrerá nenhum dano.

Os resultados desta pesquisa poderão ser divulgados apenas anonimamente (seu nome será mantido em sigilo absoluto) e para fins científicos, como congressos, publicações especializadas e cursos de formação de professores.

Certa de contar com sua autorização agradeço, antecipadamente, e me coloco à disposição para maiores esclarecimentos (andreagf4@hotmail.com ou pelo telefone 11-980168892). 


\section{AUTORIZAÇÃo}

Estando devidamente esclarecido(a) sobre os propósitos da pesquisa "Práticas de escrita em contextos de alfabetização: caminhos e descaminhos", aceito participar voluntariamente deste estudo nos termos anteriormente descritos.

São Paulo, 01 de março de 2019.

Assinatura do participante 